
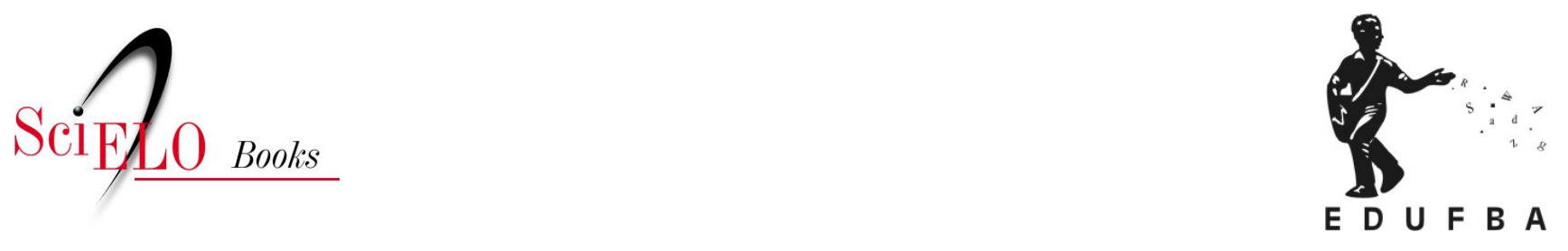

\title{
Arquitetura militar ou fortificação moderna
}

\author{
Diogo Sylveyra Vellozo
}

VELLOZO, DS. Arquitetura militar ou fortificação moderna [online]. Transcription and comments by Mário Mendonça de Oliveira. Salvador: EDUFBA, 2005. 370 p. ISBN 978-85-232-0886-8. Available from SciELO Books $<$ http://books.scielo.org $>$.

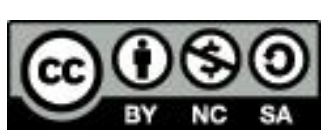

All the contents of this work, except where otherwise noted, is licensed under a Creative Commons Attribution-Non Commercial-ShareAlike 3.0 Unported.

Todo o conteúdo deste trabalho, exceto quando houver ressalva, é publicado sob a licença Creative Commons Atribuição Uso Não Comercial - Partilha nos Mesmos Termos 3.0 Não adaptada.

Todo el contenido de esta obra, excepto donde se indique lo contrario, está bajo licencia de la licencia Creative Commons Reconocimento-NoComercial-CompartirIgual 3.0 Unported. 


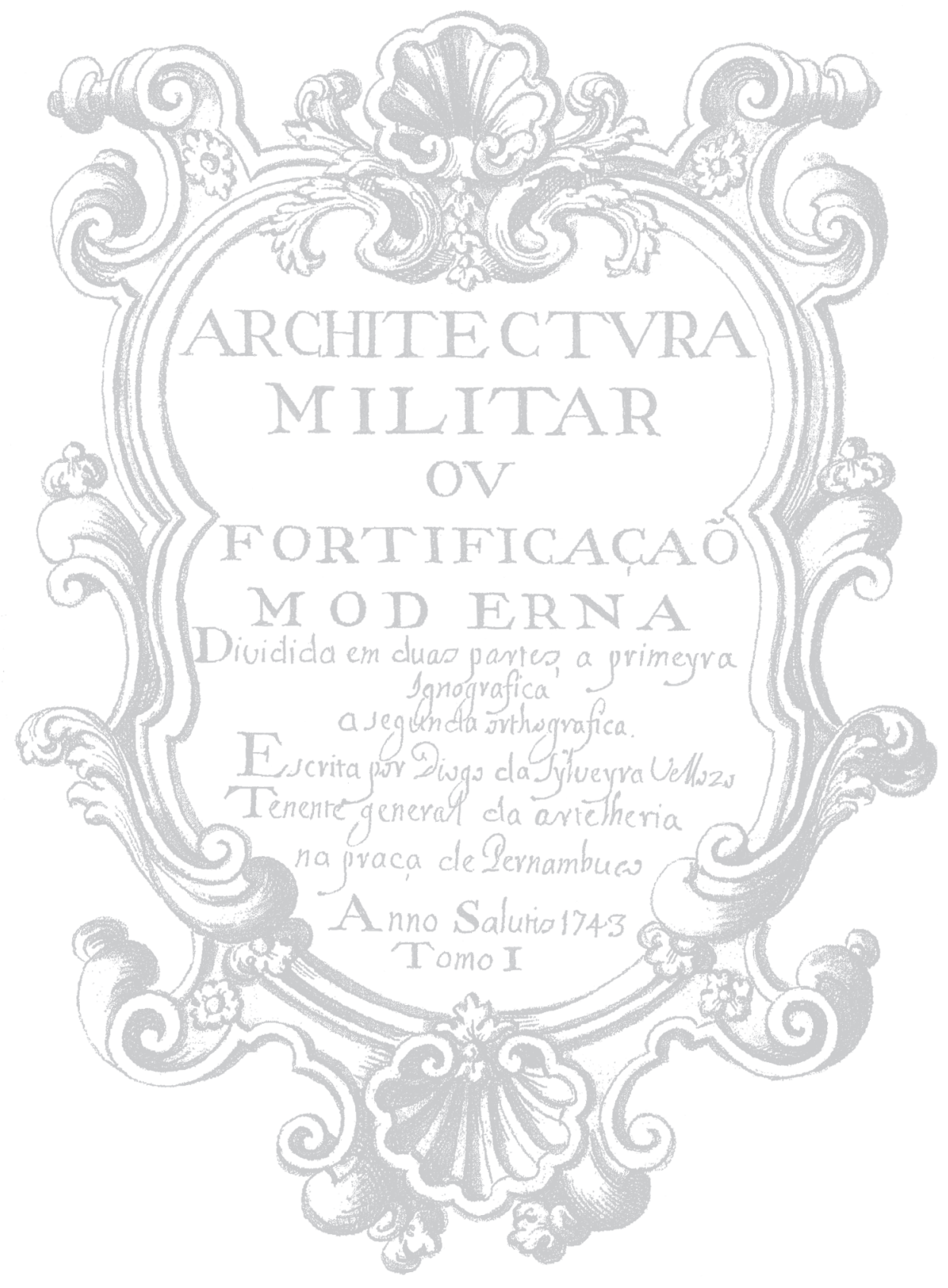




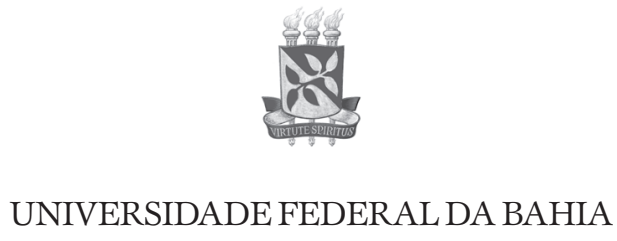

Reitor

Naomar Monteiro de Almeida Filho

Vice-reitor

Francisco José Gomes Mesquita

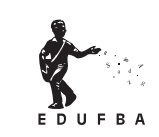

Editora da Universidade Federal da Bahia

\author{
Diretora \\ Flávia Goulart Mota Garcia Rosa \\ Conselho Editorial \\ Angelo Szaniecki Perret Serpa \\ Carmen Fontes Teixeira \\ Dante Eustachio Lucchesi Ramacciotti \\ Fernando da Rocha Peres \\ Maria Vidal de Negreiros Camargo \\ Sérgio Coelho Borges Farias \\ Suplentes \\ Bouzid Izerrougene \\ Cleise Furtado Mendes \\ José Fernandes Silva Andrade \\ Nancy Elizabeth Odonne \\ Olival Freire Junior \\ Silvia Lúcia Ferreira
}

Faculdade de Arquitetura da UFBA

Programa de Pós-graduação em Arquitetura e Urbanismo - FAUFBA

Universidade de Évora

Mestrado em Conservação do Patrimônio - UE 


\title{
ARQUITETURA \\ MILITAR \\ OU \\ FORTIFICAÇÃO \\ MODERNA
}

escrito por Diogo da Sylveyra Vellozo

\author{
Mário Mendonça de Oliveira \\ Transcrição e comentários
}

(um manuscrito da Real Biblioteca da Ajuda, Lisboa)

PPG-AU / EDUFBA / UE

Salvador-BA

2005 
๑2005, by Real Biblioteca da Ajuda, Lisboa.

Direitos para esta edição cedidos à Editora da Universidade Federal da Bahia e ao Programa de Pós-graduação em Arquitetura

e Urbanismo da UFBA. Feito o depósito legal.

\author{
Revisão \\ Mário Mendonça de Oliveira \\ Karina Matos Cerqueira
}

\author{
Projeto gráfico: capa e miolo \\ Angela Dantas Garcia Rosa
}

Biblioteca Central Reitor Macêdo Costa - UFBA

\footnotetext{
V441 Vellozo, Diogo da Sylveyra.

Arquitetura militar ou fortificação moderna / escrito por Diogo Sylveyra Vellozo ; transcrição e comentários : Mário Mendonça de Oliveira ; projeto gráfico : Angela Dantas Garcia Rosa. - Salvador : EDUFBA, 2005.

370 p. : il.

ISBN 85-232-0373-7

Um manuscrito da Real Biblioteca da Ajuda, Lisboa.

Co-edição com o Programa de Pós-Graduação em Arquitetura e Urbanismo da

Universidade Federal da Bahia e a Universidade de Évora, Portugal.

1. Arquitetura militar. 2. Fortificações. 3. Engenharia militar. I. Oliveira, Mário

Mendonça. II. Universidade Federal da Bahia. III. Universidade de Évora. IV. Título.

CDU - 725.182

CDD - 725.18
}

EDUFBA

Rua Barão de Geremoabo, s/n

Campus de Ondina

40170-290 Salvador Bahia telefax (71) 32636160 www.edufba.ufba.br www.edufba@ufba.br
FACULDADE DE ARQUITETURA Rua Caetano Moura, 121, Federação 40210-350, Salvador - Bahia - Brasil telefax: (71) 32473803 www.pos.arquitetura.ufba.br ppgau@ufba.br 


\section{APRESENTAÇÃO}

É com grande satisfação que o Programa de Pós-Graduação em Arquitetura e Urbanismo da FAUFBA publica, em parceira com a EDUFBA e o programa de pós-graduação em conservação do patrimônio da Universidade de Évora, Portugal, esta importante obra sobre a arte de construir fortificações militares.

Ao sermos indagados, pelo Prof. Mário Mendonça de Oliveira, sobre o interesse em publicar a obra "Architectura Militar", de Diogo da Silveira Vellozo, nossa resposta positiva foi imediata. A importância do texto original, a qualidade da transcrição e a pertinência dos comentários que compõem este livro nos levaram a apoiar esta publicação que traz a luz os conhecimentos sobre a construção de fortificações no século XVIII. Agora, ao vermos o livro pronto, nos sentimos honrados em ter participado desta empreitada e em fazer a apresentação do texto para os leitores.

Não há dúvida quanto a grande contribuição que esta publicação, composta por escritos que ficaram guardados por tanto tempo, traz para o preenchimento de uma importante lacuna para aqueles que se dedicam ao estudo da história da arquitetura e da construção, enriquecendo os conhecimentos da arte de construir e da arquitetura de fortificações e somando informações sobre a ciência da construção.

Através desta publicação, recupera-se a terminologia da arte de construir, a explicitação da nomenclatura das fortificações, 
o conhecimento da tipologia e a leitura das obras fortificadas, resgatando e divulgando informações históricas importantes.

Certamente, o texto a seguir, transcrito mantendo sua grafia original, proporcionará uma viagem no tempo onde poderemos compreender o ofício dos engenheiros militares do século XVIII que tanto influenciaram nas construções, na arquitetura e no urbanismo brasileiro.

Agradecemos, assim, ao Prof. Mário Mendonça por sua dedicação a este trabalho, na divulgação de obra inédita através do grande esforço para sua transcrição e seus bem construídos comentários, suprindo esta lacuna e, quem sabe, realizando o sonho deste engenheiro que não pode ver sua obra publicada.

Faculdade de Arquitetura - PPGAU Eloisa Petti Pinheiro

Coordenadora 


\section{APRESENTAÇÃO}

A oportunidade de publicação de textos antigos sobre "a arte ou sciencia que ensina a bem fortificar" é, entre nós, muito escassa. Por isso, saudamos vivamente a edição deste manual inédito do Tenente General Diogo da Silveira Velloso, escrito no Brasil em 1743 e intitulado Architectura Militar ou Fortificação Moderna. A sua difusão pela comunidade académica luso-brasileira, à qual se apresenta, permitirá que a força e a vitalidade da ancestral construção militar portuguesa, nas suas diversas latitudes e circunstâncias culturais, sejam mais apropriadamente conhecidas e estudadas. Daí, o justo cabimento desta edição conjunta sob a chancela de duas universidades que têm solidariamente colaborado e, de modo pioneiro nos respectivos países, promovido o ensino e a investigação da salvaguarda do património histórico edificado.

O compêndio ilustrado de Velloso, cujo interesse prático e significado didáctico the advêm do seu destino castrense, permanecia esquecido ou desprezado no panorama cultural dos nossos países. Esta publicação redivive um autor oitocentista, até agora pouco conhecido e que enobreceu o legado da engenharia militar portuguesa, e pretende contribuir para posicionar a sua figura e a sua obra no espaço histórico e cultural que the pertencem. Tal desiderato foi possível graças aos esforços incansáveis e entusiásticos do nosso colega e amigo Professor Mário Mendonça de Oliveira, o qual, com a sua comprovada autoridade neste domínio de especialização, transcreveu e anotou o texto vellosiano. 
Resta-nos exprimir o nosso agradecimento à Dra. Cristina Pinto Basto, Directora da Biblioteca da Ajuda, pela amável autorização para reproduzirmos esta obra manuscrita ali guardada, e à Professora Eloísa Petti, da Universidade Federal da Baía, pela generosa possibilidade de nos associarmos a esta bem-vinda publicação, no ano em que comemorámos o $16^{\circ}$ aniversário da criação, em Évora, dos estudos pós-graduados em recuperação do património arquitectónico e paisagístico.

Universidade de Évora, Outubro de 2005 Virgolino Ferreira Jorge 


\section{PROÊMIO}

Independente desta enorme carga de valor cultural e histórico que está por detrás da transcrição de um manuscrito do Século XVIII, redigido no Brasil, que nunca foi editado, seria plena justificativa trazer ao conhecimento de todos um trabalho de um aplicado engenheiro português, que dedicou a sua vida à nossa terra. Com isto estamos retribuindo uma parte do tributo do muito que devemos à engenharia militar, uma das referências dos primeiros passos da ciência da construção na nossa terra e da ciência de maneira geral. E, por que não dizer também, que por detrás de tudo existe uma motivação sentimental, e além do mais ética, de fazer divulgar um escrito, cujo autor certamente morreu frustrado por não ter visto a sua obra impressa. Que seja do nosso conhecimento, a Architectura Militar de Vellozo é o único da espécie que tivemos acesso até hoje. Muito populares e que foram efetivamente escritos no Brasil, embora editados em Portugal, foram os trabalhos do Engenheiro Militar Alpoim ${ }^{1}$. Este, porém, escreveu especificamente sobre artilharia e arte das bombas e não sobre arquitetura da fortificação.

Mesmo que tenhamos destacado, de maneira bastante enfática, a importância da Engenharia Militar na construção e defesa do Brasil no nosso texto Fortificações portuguesas de Salvador ${ }^{2}$ cabe,

\footnotetext{
${ }^{1}$ Oexame do artilheiro e O exame do bombeiro.

2 OLIVEIRA, Mário M. As fortificações portuguesas de Salvador quando Cabeça do Brasil. Salvador: Fundação Gregório de Mattos, 2004. p. 88-91.
} 
mais uma vez, sublinhar a importância destes profissionais que representavam um oásis de conhecimento e erudição no meio da soldadesca ignara do exército colonial, no qual muitos oficiais eram analfabetos. É por isto que o nosso Vellozo atreveu-se a afirmar que val mais a industria de hum bom Engenheyro, que o valor de muytos soldados.

Do ponto de vista prático a leitura dos tratados ${ }^{3}$ de engenharia militar é imprescindível para quem estuda a memória da ciência das construções, de maneira geral, eles nos lembram terminologias da arte do construir já esquecidas, explicam a nomenclatura das fortificações, facilitam o conhecimento da tipologia e a leitura das obras fortificadas que nos ficaram como legado do passado, resgatam informações históricas importantes, orientam a investigação arqueológica dos sítios fortificados e dão um retrato muito interessante da formação dos profissionais da engenharia e da arquitetura da época em que foram escritos. É bem verdade que conhecemos, e foram em muito boa hora republicados, sob os auspícios da Direcção do Serviço de Fortificações e Obras do Exército Português, os clássicos da engenharia militar portuguesa, que são citados dezenas de vezes no texto de Vellozo e obrigatórios nos documentos dos engenheiros militares de Portugal: O Methodo lusitânico, do Engenheiro-mor Serrão Pimentel, editado em 1680, e o Engenheiro português, de 1728, escrito pelo Brigadeiro Manoel de Azevedo Fortes, também Engenheiro-mor do Reino. Acontece que são volumes alentados que só podem ser digeridos pelos estudiosos apaixonados pelo assunto. O texto de Vellozo é mais leve

\footnotetext{
${ }^{3}$ Utilizamos a designação de tratado no sentido lato da palavra, como muito dos antigos engenheiros militares utilizavam, e não no sentido acadêmico, que só pode ser atribuído aos textos instauradores, como deseja Choay.
} 
e mais simplificado. Saiu, provavelmente de apostilas feitas para alunos da aula militar do Recife e procura ser extremamente didático, montando as suas argumentações de maneira metódica e incluindo escólios destacados, quando se fazia necessário e, obviamente, muitos desenhos anexos. Para cada argumento da fortificação, geralmente, relaciona os prós, destacando os autores que apóiam aquela posição e em seguida os argumentos contra, referindo os seus seguidores. No final dá a sua posição pessoal. É um texto agradável, onde o nosso autor esbanja erudição e demonstra a boa preparação dos engenheiros militares. São surpreendentes as suas citações de textos clássicos de história e arquitetura, de tratados de fortificações e outros, se atentarmos para o fato de que ele estava distanciado das boas bibliotecas do Reino.

Existem alguns colegas, dos quais respeito muito a opinião, que são favoráveis à transcrição feita em linguagem moderna dos textos antigos. Não estamos, entretanto, muito de acordo com eles no particular. Preferimos nos ater à grafia com suas hesitações, às abreviaturas com as suas mesmas obscuridades aos menores particulares do original ${ }^{4}$. O texto modernizado perde o sabor de antiguidade, esconde os vícios de linguagem do autor e pequenos enganos que comete na redação que dão mais autenticidade, mascaram formas antigas da redação, afasta-nos da intimidade da paleografia, que é necessária para consultar outras fontes primárias e, finalmente, servem somente para os estudiosos da arquitetura militar e não para os lingüistas que de posse de um texto transcrito ipsi literis et verbis podem ter um material precioso para estudo. É muito interessante

\footnotetext{
${ }^{4}$ Comunidade de S. Bento de Salvador. Livro Velho do Tombo do Mosteiro de São Bento. Salvador: Tipografia Beneditina, 1945. Prefácio de Wanderley de Pinho, p. XIV.
} 
observar a grafia de certas palavras que não mais existem nos dicionários modernos, mas que sobrevivem ainda utilizadas pela gente simples do sertão. Alguma adaptação foi admitida, porém, na transcrição para facilitar um pouco a leitura dos estudiosos: Como na escrita cursiva algumas palavras ficam agrupadas, procuramos desagrupá-las para melhor entendimento; como a letra " $\mathrm{u}$ ", muitas vezes, era usada em lugar do "v", procuramos dar uniformidade da maneira que hoje empregamos. Além do mais, usamos e abusamos de esclarecimentos nossos, que estão sempre entre colchetes, para distinguir dos parênteses que Velloso emprega de quando em vez. Todos os negritos do texto são nossos e servem para destacar vocábulos importantes, ou afirmativas de relevo.

Em determinadas partes do escrito muitas medidas são referidas, não somente através dos tradicionais palmos e pés portugueses (craveiros), mas também em medidas pertencentes a outros sistemas métricos, que eram variadíssimos naquele tempo e eram inevitáveis de serem citados, porque o nosso autor faz referências a tratados escritos e editados em outros países. Em alguns casos, o valor da medida é seguido pela equivalência em medidas portuguesas, em outros não. O maior problema está em alguns trechos onde não se sabe a que sistema de medidas está se referido Vellozo, mas, nestes casos, procuramos chamar a atenção em notas.

Espero que os leitores se deleitem intelectualmente, divirtam-se e aprendam, com a leitura deste texto, como nós o fizemos!

\section{A respeito de Diogo da Silveira Vellozo}

Diogo Vellozo, à semelhança de tantos outros engenheiros militares, deve ter vindo para o Brasil para conseguir mais facilmente acesso aos postos superiores. Uma Carta Patente Real, 
datada de 1702, dá conta de que ele foi designado para o Ultramar, para servir na Província Cisplatina, na nova Colônia de Montevidéu, recebendo para isto a mercê do posto de capitão engenheiro. Tinha ele naquela quadra a patente de ajudante. Documentação subseqüente, porém, dá a entender que ele não tenha chegado ao seu destino, nem desenhado a nova fortificação da referida cidade, porque outra Carta Patente que lhe concede o posto de Sargentomor, lavrada em 1920, resumindo o seu currículo, faz referências a duas viagens a Santos e uma a São Paulo e a Ilha Grande, sempre no exercício do seu mister de engenheiro. Fala até do seu naufrágio na foz do Rio Vaza-barris, quando ia para a praça de Recife, mas nada sobre Montevidéu. Vejamos o documento na íntegra:

Dom João etc etc. faço saber aos que esta minha carta patente virem que tendo respeito a Diogo da Silveira Vellozo me representar haverme servido dezouto annos a saber quatro de ajudante nesta corte e os mais no Brazil com o posto de capitão engenheiro fazendo muitas e repetidas [viagens] por mar e terra como forão ao Rio de Janeiro, donde servira três annos e meyo duas vezes a capitania de Santos e hua a villa de Sam Paulo noutra a Tha Grande em ocazião que se achava infestada de piratas e passando a Pernambuco naufragara na enseada de vazabarris donde se salvou despido [de] tudo quanto tinha e recolhendo [se a] sua praça por terra em distância de oitenta legoas fizera nella outras muitas jornadas do meu leal serviço com grande zello e prontidão e por esperar delle que em tudo o de que for encarregado do meu serviço se haverá com satisfação conforme a confiança que faço da sua pessoa Hey por bem fazerlhe mercê de o nomear (como por esta nomeyo) no posto de sargento mor engenheiro ad honorem com declaração que ficará com a mesma incumbência de capitão engenheiro $e$ não terá mayor soldo que com elle lograva athe agora, com o qual posto haverá etc. Dada na cidade de Lisboa occidental aos 11 dias do mês 
de setembro. Miguel de Macedo Ribeiro a fes anno do N. de N.S.J.C. de 1720.

O secretario André Lopes de Lavre a fez escrever.

El Rey

Este documento, datado de 1720 , deve referir-se a uma petição de alguns anos passados, porque nesta data já devia ter muito mais tempo de serviço do que declarado no papel. Se ele alegava na petição inicial ter servido no Reino quatro anos, na condição de ajudante, deve ter sido antes de 1702, quando passou ao Brasil com a patente de capitão.

A maior parte da vida militar e profissional de Vellozo transcorreu em Pernambuco, na Cidade do Recife, onde o nosso engenheiro constituiu família, onde galgou os postos sucessivos à sua patente inicial de capitão, escreveu seus livros, entre os quais se encontra aquele do qual nos ocupamos. Foi, igualmente, arruador da Cidade ${ }^{6}$, trabalhou na construção da Cidadela do Recife, das fortalezas do Brum, de Santo Antônio dos Coqueiros, de Nazaré e nos quartéis de Olinda. Fez algumas missões fora de Pernambuco, como a exploração de minas de ouro no sertão de Icó, no Ceará ${ }^{7}$, trabalhou na fortificação de Fernando de Noronha e assim por diante.

Vellozo, embora aparentemente não fosse abastado, era atento e zelava pela situação de sua família, tanto dos filhos que teve no $\mathrm{Brasi}^{8}$, quanto das irmãs que deixou em Portugal. Para as irmãs do

\footnotetext{
${ }^{5}$ AHU - Arquivo do Conselho Ultramarino, 1. 14, de Officios.

${ }^{6}$ AHU - Catálogo Resgate. AHU_ACL_CU_015, Cx. 39, D. 3501. Recife, 20 de julho de 1729.

${ }^{7}$ AHU - Catálogo Resgate. AHU_ACL_CU_015, Cx. 39, D. 3541 e AHU_ACL_CU_015, Cx. 39, D.3564.

${ }^{8}$ Foram quatro filhos dos quais pelos menos três era mulheres.
} 
outro lado do Atlântico, procurava mandar algum apoio financeiro ${ }^{9}$ ou mercadorias que pudessem ser vendidas para o seu sustento. É nossa crença de que esta mercadoria deveria ter sido para negociar, porque as dezoito caixas de açúcar branco que mandou em 1725 não deveriam ser para consumo familiar ${ }^{10}$. Existem indicações documentais de que, pelo menos no início da sua vida, o nosso engenheiro não era homem de fortuna, porque quando foi nomeado Sargento-mor, o Rei, sempre avaro da sua Fazenda Real, conservou-lhe o mesmo salário de capitão engenheiro, como se vê no documento transcrito anteriormente. Em 1726 Vellozo ainda pedia que lhe fosse concedido o salário do posto de sargento-mor, para o qual tinha sido nomeado desde 1720. Isto também está textualmente referido na carta que a Câmara do Recife faz a D. João $\mathrm{V}$ sugerindo que nosso tratadista passasse a receber uma ajuda de custos do dito Senado da Câmara para exercer a atividade de cordeador e arruador, em vista da falta de patrimônio do mesmo ${ }^{11}$. Que ele não era protegido da Corte estava também claro, porque as mercês viriam muito mais facilmente se assim o fosse. Em todo o caso, tinha a prerrogativa de ter nascido em Portugal e, conseqüentemente, contar com maior confiança do Rei para receber promoções, situação bastante diferente dos engenheiros militares que nasceram no Brasil.

\footnotetext{
${ }^{9}$ Este apoio financeiro deveria ser feito em função de uma mesada que era descontada do seu salário e paga a um Procurador na Corte. AHU - Catálogo Resgate. AHU_ACL_CU_015, Cx. 58, D. 5016. Anterior a 1743. Tanto isto é verdade que, em 1746, pede que seja pago o seu soldo integralmente por ter cessado a aplicação que fazia para a sua irmã Isabel Maria da Silveira. AHU - Catálogo Resgate.AHU_ACL_CU_015, Cx. 64, D. 5471.

${ }^{10}$ AHU - Catálogo Resgate. AHU_ACL_CU_015, Cx. 32, D. 2973. Recife, 27 de agosto de 1725.

${ }^{11}$ AHU - Doc. cit. D. 3501.
} 
Em 1729, Diogo Vellozo retorna a Portugal, por ordem do Governador Duarte Sodré Pereira Tibão, para relatar as dificuldades de execução do projeto de fortificação da Cidade do Recife ${ }^{12}$ especialmente da sua Cidadela. Teve a oportunidade de expor e discutir as propostas para este sistema de fortificações com os mais importantes engenheiros militares da Corte, o Brigadeiro Manoel de Azevedo Fortes, Engenheiro-Mor do Reino, o Brigadeiro João Massé e o Coronel José da Silva Paes, que juntos elaboraram um parecer sobre o assunto encaminhando à instância real ${ }^{13}$. Aproveitando a oportunidade de estar na Corte peticiona ao soberano para ser promovido ao posto de Tenente General, o que só veio acontecer depois, provavelmente, em torno do ano de 1730. Regressando ao Brasil e tendo recebido a promoção solicitada, tem-se notícia de uma contenda com um certo sargento-mor comandante de um dos terços de Pernambuco, sobre a precedência dos seus postos. Estas contendas sobre as patentes dos engenheiros militares eram muito freqüentes, quando alguns comandantes de unidades não queriam reconhecêlas ou respeitá-las, divergências que eram decididas sempre na Corte em favor dos engenheiros, pelo menos enquanto Azevedo Fortes foi o Engenheiro-mor do Reino ${ }^{14}$.

Em 1735 a carreira de Diogo da Silveira Vellozo sofre uma inflexão, muito mais aparente do que real. Com a morte do Tenente-general de Artilharia João de Macedo Corte Real, ele pede e consegue ocupar a vaga aberta pelo falecimento do antigo

\footnotetext{
${ }^{12}$ AHU - Catálogo Resgate. AHU_ACL_CU_015, Cx. 39, D. 3540. Lisboa, 16 de novembro de 1729 .

${ }^{13}$ AHU - Catálogo Resgate. AHU_ACL_CU_015, Cx. 39, D. 3541. Lisboa, 17 de novembro de 1729 .

${ }^{14}$ AHU - Catálogo Resgate. AHU_ACL_CU_015, Cx. 42, D. 3812. Recife, 19 de março de 1732 .
} 
comandante inserindo-se assim nos quadros da artilharia ${ }^{15}$. Isto não quer dizer, todavia, que ele se afastasse do exercício da engenharia. Naqueles tempos, os engenheiros, em geral, por estarem afeitos ao manejo das geometrias, da trigonometria, dos levantamentos de campo e dos cálculos estavam, na maioria dos casos, habilitados para operar na artilharia. Observe-se, porém, que os documentos continuam falando das atividades de Vellozo na engenharia, como na viagem que fez a Fernando de Noronha em 1739, para melhorar as suas fortificações, à Paraíba para onde foi projetar uma nova fortaleza ${ }^{16}$. Nesta época é que fez um projeto e orçou uma ponte, em Itapissuma, na Ilha de Itamaracá. Esta pequena mudança de rumo na atividade de Vellozo parece que lhe trouxe maior prestígio na carreira militar, porque na qualidade Tenente de Mestre de Campo General, engenheiro e Comandante da Artilharia era o cabo maior ou comandante supremo da artilharia na Província de Pernambuco e por isto poderia pretender do Rei a autorização ${ }^{17}$ para adjudicar à sua autoridade a função de nomear os condestáveis e outros subordinados da artilharia nos presídios de Pernambuco ${ }^{18}$.

As fontes primárias também afirmam que o nosso tratadista foi lente da aula militar de Pernambuco ${ }^{19}$. Em carta enviada

\footnotetext{
${ }^{15}$ AHU - Catálogo Resgate. AHU_ACL_CU_015, Cx. 48, D. 4289. De 7 de março de 1735.

${ }^{16}$ AHU - Catálogo Resgate. AHU_ACL_CU_015, Cx. 53, D. 4635. Anterior a 1739.

${ }^{17}$ AHU - Catálogo Resgate. AHU_ACL_CU_015, Cx. 56, D. 4867. Anterior a 1740.

${ }^{18}$ Convém chamar a atenção sobre dois termos. O primeiro deles é condestável que muitos entendem como um título nobiliárquico, mas que, na verdade, é uma patente da artilharia que era formada de bombardeiros, gentilhomens e condestáveis. A outra é presídios que significam nos documentos antigos praças fortificadas e não significam prisões, como já escutamos por aí.

${ }^{19}$ AHU - Catálogo Resgate. AHU_ACL_CU_015, Cx. 55, D. 4761. Datado de 24 de novembro de 1739 .
} 
a D. João V, o Governador da Capitania de Pernambuco, Henrique Luís Pereira Freire de Andrade alega ser necessário haver continuidade de aula militar e partidistas ${ }^{20}$, como [...] houve no tempo do tenente João de Macedo ${ }^{21}$, sucedido por Diogo da Silveira Velloso e a este Luiz Xavier Bernardo ${ }^{22}$ [...]. Pode-se observar que as inúmeras missões e deslocamentos de Vellozo eram incompatíveis com a sua atividade docente. Da sua atividade como engenheiro restaram também alguns desenhos que são referidos por Viterbo no seu Dicionário, segundo ele sob a guarda do Arquivo Militar do Exército no Rio de Janeiro, referentes a fortificações da Cidade do Recife. Conhecemos, entretanto um desenho dele relativo ao Forte da Laje, na entrada da Baía de Guanabara, no Rio de Janeiro, que se encontra no Arquivo Histórico Ultramarino ${ }^{23}$. Pela data deve ter sido uma das primeiras atividades logo que chegou ao Brasil.

O Tenente de Mestre de Campo General, engenheiro e Comandante da Artilharia Diogo da Silveira Vellozo deve ter falecido em 1750, ou pouco antes, porque para o seu posto, vago por morte, foi indicado pelo Governador Luís José Correia de Sá, o Capitão de Artilharia Jerônimo Mendes da Paz. Teve uma vida profissional muito ativa e, pelo que podemos deduzir dos documentos que

\footnotetext{
${ }^{20}$ Uma espécie de bolsistas que recebiam proventos para freqüentarem a aula militar. Nem todos os alunos eram partidistas, pois alguns seguiam o curso sem receberem apoio financeiro.

${ }^{21}$ Deve tratar-se do engenheiro militar João de Macedo Corte Real, que serviu em Pernambuco.

${ }^{22}$ Luiz Xavier Bernardo foi engenheiro militar famoso na Província de Pernambuco que chegou ao Brasil em 1716, segundo Viterbo. Serviu, inicialmente, em Portugal na província de Trás-os-Montes, na qualidade de Ajudante Engenheiro. Para conseguir promoção foi nomeado Capitão Engenheiro da Paraíba, mas acabou conseguindo fixar sua sede em Recife. Foi um dos colaboradores do Brigadeiro Massé quando este veio em missão ao Brasil opinar sobre as fortificações do Rio de Janeiro, Bahia e Pernambuco (e vizinhanças).

${ }^{23}$ AHU - Iconografia manuscrita, Rio de Janeiro: RJ- 1058A/9 e 1059.
} 
falam da sua carreira militar, adquiriu prestígio e respeito como pessoa e como profissional da engenharia militar. Além do texto Arquitectura Militar ou Fortificação Moderna, do qual nos ocupamos transcrevendo e comentando, conhecemos dele dois outros trabalhos igualmente sob a guarda da Biblioteca Real da Ajuda: Geometria prática Tomo I, dividido em tres tratados escritos por Diogo da Sylveyra Vellozo - Ten. de Mestre de Campo G. ${ }^{a l}$ com exercício de engenheyro na praça de Pernambuco - 1669 [?] $]^{24}$ e Opusculos geométricos recopilados no presente volume por Diogo da Silveyra Vellozo Tem $G^{a l}$ de Infantaria com exercício de Engenheyro na Praça de Per ${ }^{c 0}, 1732^{25}$.

\section{AGRADECIMENTOS}

Devemos agradecer, inicialmente, à Biblioteca da Ajuda, que nos concedeu acesso ao texto de Vellozo e autorizou a sua publicação. Ao caro amigo Prof. Virgolino Ferreira Jorge que promoveu, através da Pós-graduação em Conservação do Patrimônio da sua Universidade a associação com o nosso PPG-AU (Programa de Pósgraduação em Arquitetura e Urbanismo) conseguiu as licenças necessárias para uma publicação conjunta com a Universidade de Évora. Ao PPG-AU que abraçou incondicionalmente o projeto de um dos seus docentes para a publicação deste texto, uma empreitada extremamente simbólica das ligações culturais entre Portugal e Brasil, já que o nosso engenheiro de origem portuguesa dedicou

\footnotetext{
${ }^{24}$ Biblioteca da Ajuda, cota: 49-02-85. A data de 1699 nos parece um engano de referência, porque nesta época Vellozo deveria ser Ajudante e não ter partido ainda para Pernambuco.

${ }^{25}$ Biblioteca da Ajuda 49-02-84.
} 
a sua vida profissional à nossa terra. De fundamental importância foi também a participação de duas importantes colaboradoras. Uma delas Raimárcia Pereira que fez cópias em AUTOCAD das estampas do texto, trabalhando sobre os desenhos originais microfilmados e, especialmente, Karina Matos Cerqueira que deu uma enorme colaboração, não somente nos desenhos, como na transcrição do texto, conseguindo grande familiaridade com a caligrafia de Vellozo e participando do clima de grande entusiasmo que cercou este trabalho agradabilíssimo e gratificante. 


\section{[SUMÁRIO]}

Parte $1^{\text {a }}$ : Iconografia

Cap. $^{\circ} 1^{\circ}$ Que couza seja fortificação. Seus princípios, e aagmentos [sic].

$\operatorname{Cap.~}^{\circ} 2 .^{\circ}$ Da necessidade da fortificação. 30

Cap. $^{\circ} 3 .^{\circ}$ Se he melhor fortificar as fronteyras ou o meyo do estado 36

$\operatorname{Cap.~}^{\circ} 4^{\circ} \quad$ Da qualidade dos sitios e quais são melhores para se haverem de fortificar

$\operatorname{Cap}^{0}{ }^{5} .^{\circ}$ Das maximas geraes da fortificação 49

Cap. $^{\circ}$ 6. ${ }^{\circ}$ Dos nomes das linhas, e angulos da fortificação no que toca a explicação da planta ignografica .....51

$\operatorname{Cap.~}^{\circ}$ 7. $^{\circ} \quad$ Do modo de tirar a planta do terreno para assento da fortificação.

$\operatorname{Cap.~}^{\circ}$ 8. $^{\circ}$ Do desenho das fortificações das praças assim regulares, como irregulares do poligono exterior p. ${ }^{\text {a dentro. }}$ 58

Cap. $^{\circ}$ 9. ${ }^{\circ}$ Do desenho do lado do poligono interior para fora nas praças regulares.

Cap. $^{\circ}$ 10. ${ }^{\circ}$ Do mesmo desenho do poligono interior

p. ${ }^{a}$ fóra nas praças irregulares.

$\mathrm{Cap}^{\circ}{ }^{0} 11 .^{\circ}$ De outro modo de desenhar as figuras irregulares do poligono interior $\mathrm{p}^{\text {a }}$ fora. 
$\operatorname{Cap}^{\circ}{ }^{12}{ }^{\circ}$ Da linha fechante e alcance do tiro de mosquete. ............................................................. 76

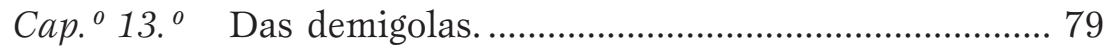

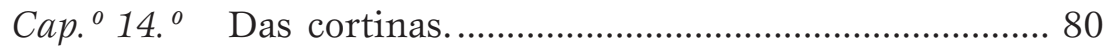

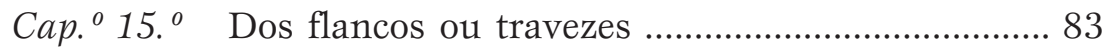

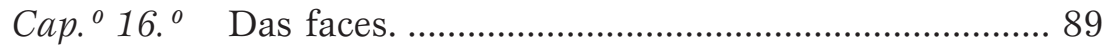

$\operatorname{Cap}^{\circ}$ 17. ${ }^{\circ}$ Do angulo flanqueado qual he melhor se agudo, recto ou obtuzo. ...................................... 93

$\mathrm{Cap}^{\circ}{ }^{18}{ }^{\circ}$ Da grandeza do lado do poligono exterior, e tambem interior para se fortificarem com baluartes inteyros.

Cap. $^{\circ} 19 .^{\circ}$ Do valor dos angulos e grandeza das linhas que rezultão das proporções explicadas nos capitulo $8 .^{\circ}$ e $9 .^{\circ}$

$\operatorname{Cap}^{\circ}{ }^{2} 2 .^{\circ}$ Do methodo particular de alguns AA [autores] modernos para fortificar assim do lado exterior para dentro, como do interior para fora.

Cap. $^{\circ} 21 .^{\circ}$ Dos fossos.

Cap. $^{\circ}$ 22. ${ }^{\circ}$ Se a contra-escarpa será melhor parallela ou obliqua as faces dos baluartes.

$\operatorname{Cap.~}^{\circ} 23 .^{\circ}$ Propoem-se outras questões pertencentes aos fossos.

Questão 1. ${ }^{a}$ - Se he melhor o fosso mais largo e menos fundo, ou mais fundo menos largo.

Questão 2. ${ }^{a}$ - Qual he melhor se o fosso seco ou aquatico.

Questão 3. ${ }^{a}$ - Se a contraescarpa deve ser revestida de muro de pedra e cal, ou não. 136

Cap. $^{\circ} 24 .^{\circ}$ Da forma de desenhar os fossos. 138 
Cap. $^{\circ}$ 25. ${ }^{\circ}$ Dos refossetes

$\operatorname{Cap}^{\circ}{ }^{26}{ }^{\circ}$ Da estrada encuberta, seu parapeyto, e explanada.

\section{Parte $2^{\mathrm{a}}$ : Orthografia}

Cap. $^{\circ} 1^{\circ}$ Dos termos e nomes pertencentes a orthografia, ou explicação do perfil das fortificações. ............ 153

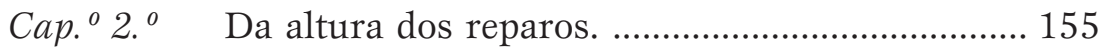

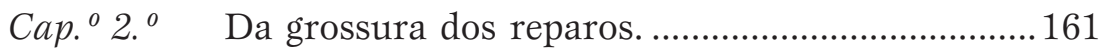

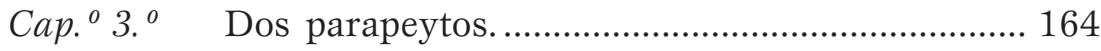

Cap. $^{0} 4{ }^{\circ} \quad$ Da gossura dos parapeytos ..................................... 171

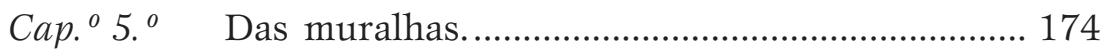

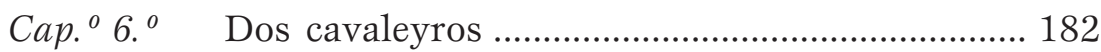

Cap. $^{\circ}$ 7. $^{\circ}$ Dos flancos cubertos com orilhões,

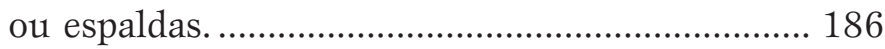

Cap. $^{\circ} 8{ }^{\circ} \quad$ Dos flancos altos e bayxos. .................................... 192

Cap. $^{\circ}$ 9. ${ }^{\circ}$ Do baluarte, se por ser grande requere mayor numero de gente para guardallo, e defendello do que requere sendo pequeno. .... 204

Cap. $^{0} 10{ }^{\circ}$ Se os baluartes devem ser cheyos ou vazios. ..... 206

Cap. $^{0} 11 .^{\circ}$ Se são melhores os baluartes atacados ás cortinas, ou separados do corpo da praça. 208

$\operatorname{Cap.~}^{\circ} 12 .^{\circ}$ Das obras que se costumão fazer dentro

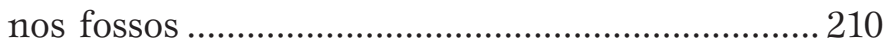

Cap. $^{\circ} 13 .^{\circ}$ Das capoeyras e cofres. .216 
$\operatorname{Cap}^{\circ}{ }^{14}{ }^{\circ}$ Das diversas estacadas que se fazem dentro e fora do fosso.

$\mathrm{Cap}^{\circ}{ }^{0}$ 15. $^{\circ} \quad$ Das portas, tranzitos, e pontes. .......................... 225

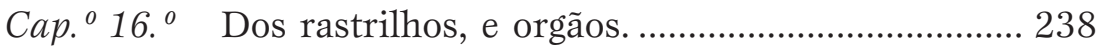

Cap. $^{\circ}$ 17. ${ }^{\circ}$ Dos corpos de guarda que se fazem encostados ás paredes do tranzito .......................................... 240

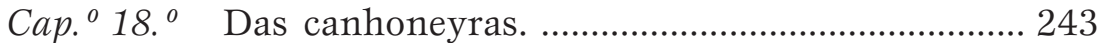

Cap. $^{\circ} 19 .^{\circ}$ Dos leytos para laborar a artelheria .................... 248

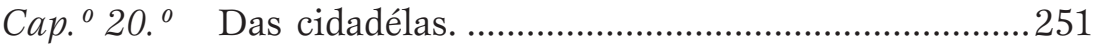

$\mathrm{Cap}^{\circ}{ }^{\circ} 21 .^{\circ}$ Das obras exteriores em geral ............................. 255

Cap. $^{\circ}$ 22. ${ }^{\circ}$ Das traveças. ........................................................... 279

Cap. $^{\circ}$ 23. ${ }^{\circ}$ Da fortificação das praças situadas junto da agua, e daquellas por dentro das quais passa alguma ribeyra

Cap. $^{\circ} 24 .^{\circ}$ Dos fundamentos, e alicerces das muralhas......................................................... 288

$\operatorname{Cap.}^{\circ} 25 .^{\circ}$ Da escolha dos materiays para a fabrica da muralhas.

Cap. $^{\circ} 26{ }^{\circ}$ Do instromento chamado arpa necessario para se darem as escarpas aos reparos, parapeytos, e muralhas. 302

Cap. $^{\circ} 27^{\circ}$ Do modo com que se devem obrar os terraplenos. 305

\section{Estampas}


Parte $1^{\mathrm{a}}$

\section{Iconografia}


Architectura melitar

ou

Arte pratica da

Fortificação moderna

Parte $1^{\text {a }}$ Ignografica ${ }^{1}$

\section{$\operatorname{Cap}^{\circ} 1^{\circ}$ \\ QUE COUZA SEJA FORTIFICAÇÃO \\ SEUS PRINCÍPIOS, E AAGMENTOS [sic].}

Fortificação, ou Architectura melitar, não he outra couza mais que hu'a arte ou sciencia que ensina a bem fortificar, e defender toda a sorte de praças contra a invazão dos inimigos.

Os seus principays fins são dous: o primeyro de poder com pequeno numero de gente rezistir a muyta do inimigo: o segundo conservar seguros os habitantes do lugar fortificado contra os accidentes da guerra.

No principio do mundo as mais bellas campanhas erão as mais agradaveys habitações; a segurança dos habitadores consistia na inocência de todos: mas tanto que a cobiça, e ambição começarão a conromper [sic] os corações dos homens, logo foy necessario armarem-se huns contra a violencia dos outros, donde nasceo a arte de

\footnotetext{
${ }^{1}$ Embora encontremos alguns escritos sobre fortificação que apresentem uma grafia similar, com uso da letra "g", parece-nos que não se trata de uma forma antiga de escrever a palavra, mas uma forma errada. Serrão Pimentel, no Século XVII escreve no seu tratado uma forma derivada diretamente do latim, língua na qual era versado e que deve ser a forma antiga correta: Ichnographia, oriunda diretamente do latim ichnographia, $\alpha$, como Vitrúvio escreveu no seu tratado de Arquitetura: Ichnographia est circini regulaque modice continens usus, e qua capiuntur formarum in solis arearum descriptiones. Azevedo Fortes, que era também um erudito, escreve, no Engenheiro Português (Século XVIII), a palavra ichnographia da mesma maneira que Serrão Pimentel.
} 
fortificar, que foy em seu principio simplex, rude, e imperfeyta, como todas as mais artes, e inventos; hoje porem tem chegado ao auge da mayor perfeyção, hindose cada ves mais aperfeysoando o modo das defenças, assim como pela violência de huns, e obstinação de outros se hião achando novos generos de armas e machinas offencivas.

Pouco depoys deste tempo costumavão cercar as cidades e villas em torno com muros de tal altura que se the não pudessem facilmente arrimar escadas: a largura ordinariamente era tanta que por elles pudecem marchar tres ou quatro homens de frente: mas esta fabrica tinha dous defeytos ambos grandes, e capitays: o primeyro, q' os defensores postos sobre os muros ficavão descubertos, e expostos aos tiros dos inimigos, por não terem parapeytos com que se cobrirem: o segundo, que chegando o inimigo ao pé da muralha ficava cuberto com a mesma muralha sem poder ser offendido do alto della.

A estes inconvenientes se tratou logo de acodir remediandose pela maneyra seguinte;[:] cercavão o muro em roda com hum parapeyto continuado, e o alto delle se dividia em ameyas, não continuadas, mas separadas hu'a da outra detraz das quais ficavão os defensores seguros, e pellos espassos abertos arremecavão as lanças e pedras para deter ao inimigo que não chegasse ao muro. Desta sorte ficava emmendado de algum modo o primeyro erro.

Para obviar ao segundo desde o chão athe a altura de hum homem abrião no muro frestas a que chamavão seteyras, porem nem ainda assim se evitavão os ditos inconvenientes, porquanto o inimigo não podia ser offendido em se metendo nos espaços entre huma e outra seteyra, ${ }^{2}$ como se pode ver na figura $1^{\text {a }}$.

\footnotetext{
${ }^{2} \mathrm{Na}$ realidade este inconveniente, em períodos mais antigos, era muito mais evitado com um desenho da muralha que colocava em balanço o parapeito, ou parte dele, conhecido pelos franceses como machicoulis ou pelos italianos como caditoie. Para maiores esclarecimentos ver Cassi Ramelli - Dalle caverne ai refigiblindati e Viollet-le-Duc - Dictionnaire raisonnéde l'arachitecture française, no verbete machicoulis. Os portugueses chamavam simplesmente de balcão.
} 
Tratarão por tanto de valerse de defenças colaterays, e retendo as ameyas e frestas, edificarão torres quadradas em roda dos muros encostadas a elles; dobrando por este modo as defenças para infestar ao inimigo pella frente, e pelos lados: nesta forma erão edificados os muros de Babilônia, contados por huma das sete maravilhas do mundo, cujo âmbito era de 368 estadios $^{3}$, dos quais cada hum contem 125 passos, como refere Quinto Curtio liv 4º a largura era de 32 pés, a altura de 75 , ficando as torres 10 pés mais altas $^{4}$ que o resto da muralha, obrado tudo de tijollo e betume: porem ainda esta defença colateral era imperfeyta, podendose o inimigo occultar em certo espaço na frente das ditas torres.

Pello que reprovadas as torres quadradas, se principiarão a fabricar outras redondas, por esta maneyra o espaço dentro do qual o inimigo se occultava ficou assas diminuido, não podendo o inimigo dentro nelle dispor os arietes; e a forma das torres redondas era sem duvida mais firme para resistir ao impulso, e violencia dos ataques. Nesta invenção se aquietou a arte, e o esforço dos antigos, athe que achada a polvora aprenderão os homens a fabricar rayos, e a imitar trovões, para que assim a roina de huns fosse o aumento dos outros.

Foy inventor desta mais que diabolica compozição Bertoldo Schuart $^{5}$ alchimista natural de Alemanha pelos annos de 1354.

\footnotetext{
${ }^{3}$ Uma vez que Vellozo refere-se a um autor latino, esta medida deve estar expressa em estádios (Stadium, ii) romanos. O estádio romano corresponde a $\sim 185 \mathrm{~m}$ cada, o que dá um total de $68.080 \mathrm{~m}$. Este valor do estádio corresponde a 625 pés romanos de $0,2962 \mathrm{~m}$ cada e a 600 pés gregos de $0,3086 \mathrm{~m}$ cada.

${ }^{4}$ Se esta referência é feita em pés portugueses estas muralhas teriam $12,21 \mathrm{~m}$ de espessura, altura de $24 \mathrm{~m}$ e altura de torres $28 \mathrm{~m}$. Se as medidas são em pés romanos, o que não está claro no texto, seriam medidas ligeiramente inferiores já que o pé romano equivalia a $0,294 \mathrm{~m}$, em vez de $0,33 \mathrm{~m}$ dos portugueses.

${ }^{5}$ Berthold Schwartz é considerado por alguns como o pai da invenção da pólvora, em 1354, mas, a maioria dos estudiosos da matéria considera este invento anterior ao Século XIV. Sobre o assunto tivemos a oportunidade de fazer uma análise no nosso texto Asfortificações portuguesas de Salvador quando Cabeça do Brasil, p. 22-23.
} 
Seguiose a este invento o da artelheria posta em praxe a primeyra vez pelos Venezianos na guerra que tiverão com os genovezes junto a Chioza no anno de 1380. Pelo que supposto aquelle modo de fortificar fosse melhor que os primeyros com tudo, como ainda havia espaço capaz para nelle se occultarem os mineyros, e as defenças colaterays somente tocavão em dous pontos as torres redondas, porque os corpos redondos so podem ser tocados em hum ponto por hu'a linha recta como se provou na prop. 13 do liv. $3^{\circ}$ dos Elementos de Euclides: por tanto vencendose a arte a sy mesma inventou o modo de fortificação de que hoje se uza, mudando as torres redondas em baluartes compostos de faces, e flancos, e os muros acrescentandolhes groços reparos de terra, terminandose toda a fortificação com linhas rectas, de que rezultou que em qualquer parte que o inimigo se ponha fica descuberto aos tiros dos defensores, e todas as partes da fortificação se flanqueão humas ás outras, que he a primeyra e principal maxima da fortificação moderna ${ }^{6}$, da qual intentamos tratar, segundo o uzo dos melhores mestres como no discurso se verá.

\section{$\operatorname{Cap}^{\circ}{ }^{2} .^{\circ}$ \\ DA NECESSIDADE \\ DA FORTIFICAÇÃO.}

Alguns politicos modernos se atreverão a reprovar as fortificações, opinião que seguirão antigamente os Spartanos (erão os povos que habitavão antigamente a provincia da Morea) e seguem

\footnotetext{
${ }^{6}$ Como afirmamos no nosso trabalho sobre as fortificações portuguesas de Salvador, o flanqueamento das defesas era uma verdadeira obsessão. Podemos considerar que era a máxima de maior importância no desenho das defesas, a partir da fase dita Moderna dos sistemas fortificados.
} 
hoje os Polacos fundados em algumas razões aparentes, que facilmente se podem desfazer.

Dizem primeyramente que todas as fortalezas uniformemente se perdem por hu'a de tres cauzas, a saber, por engano a que dão o nome de entrepreza, por força a que chamão sitio formal, ou por fome a que dizem assedio [negritos do comentarista], e que perdido hum estado fortificado, perde juntamente o Principe a esperança de o recuperar, salvo for com muyto tempo e grandissima despeza; quando pelo contrario o estado sem fortalezas se facilmente se perde, tambem facilmente e com pouca despeza se recupera.

Acrescentão em segundo lugar, que as fortificações não impedem a conquista dos estados, porque quem he senhor da campanha se faz em breve senhor das praças fortificadas, de que rezulta não servirem estas mais que de fazerem que os povos se rebelem, e percão o amor e reverencia a seus Principes naturays.

Alem disto acrescentão que as fabricas e prezidios das praças fortificadas esgotam os tezouros dos Reys, que fora melhor conservalos para na occazião por hum exercito em campanha, ou mantelo continuamente para impedir os progressos do inimigo.

Confirmão estas razões com o exemplo de alguns Principes, e povos que desmantelarão muytas fortalezas, como fizerão os Romanos a muytas cidades de espanha, segundo refere Tito Livio liv. 24, e mais modernamente como fes o Duque de Urbino quando recuperou o seu ducado, de que o tinha despojado Cezar Borja filho do Papa Alexandre $6^{\circ}$, como refere Guichardino istoria de Italia liv. 13, e como fes ultimamente Luiz 13 Rey de França havendo sugeytado a cidade da Arrochela, e outros muytos ${ }^{7}$.

\footnotetext{
${ }^{7}$ Vamos observar, no decorrer do texto, a grande erudição do autor, no que toca á história antiga e recente, especialmente sob o tema das artes bélicas citando, com referências especificadas, autores antigos e "modernos" como cronistas e historiadores.
} 
Para se mostrar a vaidade destas razões se deve primeyro saber que os Principes que tem praças fortificadas podem ser de tres sortes Pequenos, Medianos, e Grandes. Os pequenos com praças fortificadas, e sem ellas são de pouca concideração; com tudo tambem estes quando são animozos se tem defendido com fortalezas contra forças muyto mayores athe serem socorridos dos vezinhos, que por ciumes de que outros se não fação mais poderozos, ou por outra razão de estado se moverão promptamente a darlhes sufficiente socorro: assim succedeu aos Principes de Monaco na Ribeyra de Genova, e aos de Mirandola na Lombardia.

Os Principes de Mediana potencia tem necessidade sem duvida alguma de praças fortes, porque não sendo bastantes a manter exercitos numerozos em campanha, estarião em continuo pavor, ciumes, e sospeytas de guerra por cauza dos vezinhos mais poderozos: estarião tambem expostos continuamente ao arbitrio dos povos inquietos, e vulgo ignorante que por ligeyras occaziões se amotinão, e amão as novidades, dezejando experimentar se com a mudança de dominante podem melhorar de fortuna: por estas, e semelhantes cauzas são necessarias aos Principes medianos as fortalezas para que se possão defender athe serem ajudados de seus confederados, com os quais devem estar em amigavel concordia, e com liga firme; porque se forem Principes grandes, darão grandes socorros; se pequenos não farão pouco com as forças unidas.

Os Principes grandes posto que á primeyra vista pareça não terem muyta necessidade de fortificações por serem as suas forças formidaveys aos vezinhos, de modo, que ou nunca, ou raras vezes são offendidos e provocados, sendo bastantes assim $\mathrm{p} .{ }^{\mathrm{a}}$ a propria defença, como para a offença: com tudo a $\mathrm{q}^{\mathrm{m}}$ bem o conciderar, he manifesto, que tambem aos Principes grandes são necessarias 
as praças fortes; porque sendo o seu dominio grande, he força que confine com outros muytos povos; e posto que seja superior em forças a cada hum de persy, com tudo o não será a todos juntos, e

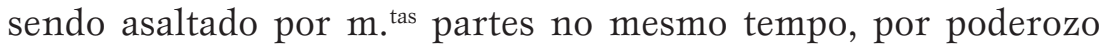
que seja, não poderá pôr tantos exercitos em campo juntamente que possa não so offendelos, mas rezistirlhes.

Mas he tempo de responder as objeções contrarias, e em quanto a dizerem que todas as praças se perdem finalmente por engano, força, ou por fome, se responde consedendo ser possivel renderem-se as praças por algum dos ditos modos, mas negando que necessariamente se hajão de render; porque muytas, e muytas vezes se tem defendido, e conservado: basta o exemplo moderno de Viena de Austria que no anno de 1683 se defendeu contra o exercito formidavel de Mahometo $4^{\circ}$ Emperador dos Turcos, que constava de 300 mil homens, e se não fora a rezistencia que encontrou naquella cidade houvera penetrado athe o coração de Alemanha, e destruido, e asolado toda a provincia: destes e semelhantes exemplos estão cheyos os livros e historias.

E nem todos os enganos, e estratagemas que se ordenão para conquistar hu'a praça conseguem o fim pertendido, porque nem sempre os governadores são remissos, e descuydados; antes ordinariamente se escolhem para aquelles cargos homens de prudencia, e vigilancia e o querer ganhar hu'a praça por fome he couza de muyta dilação, e entre tanto succede, que ou por doenças, ou por inundações, frios, ou calores excessivos perece grande parte dos citiadores, e os mais são constrangidos a levantar o sitio.

He tambem falso afirmar que os estados perdidos facilmente se recuperão quando nelles não ha praças fortes, mas que havendoas, hu'a vez perdidas não podem ser restauradas sem grande trabalho, 
despeza e dilação de tempo. Confessamos que as fortalezas fazem mais dificultoza a recuperação do estado perdido, mas quem não ve que se he dificultoza esta recuperação do estado, muyto mayor havia de ser primeyro a conquista; alem de que quando o estado não tem fortalezas o inimigo q' o ganhar tratará logo de as fabricar á custa dos vencidos fazendo-os trabalhar nellas por força.

Dizem mais os da opinião contraria que as fortalezas não impedem a conquista a quem he senhor da campanha. He esta razão tão manifestamente falsa que não necessitava de resposta. Ganharão os Holandezes no anno de 1600 a celebre batalha de Neuport contra o Archiduque Alberto, e ficarão senhores da campanha, mas em razão das praças fortificadas não so não ganharão Flandres, mas nem mais hum so palmo de terra. Cazal conservou o Monferrato ao Duque de Mantua. Inglostadio impedio os progressos de Gustavo Adolfo em Baviera. Elvas deteve perto de quatro mezes hum poderoso exercito de Castella, e quem ler as historias encontrará outros muytos exemplos assim antigos como modernos em confirmação da utilidade grande que rezulta da Architectura militar a todos os senhorios.

Que as fortalezas fação perder aos subditos o amor devido aos Principes naturays he manifestamente falso; porque ou os subditos são hereditarios, e costumados a viver debayxo do dominio e governo de huma familia, ou são conquistados por força: aquelles se contentarão muyto de agradar ao Principe seu natural, estes por medo das fortalezas, e suas guarnições não se atreverão a perder a obediencia e sacodir o jugo.

Nem he bom remedio contra as invazões dos contrarios ter continuamente pago hum exercito em campanha, ou levantallo de novo quando o inimigo entra no paiz a subjugalo; porque o man- 
ter hum exercito continuamente em campo he couza de muyto mayor dispendio que as fortalezas, alem dos muytos accidentes a que o dito exercito em campanha esta sugeyto; e o levantallo de novo para rezistir ao inimigo ao tempo da invazão he de grande perigo, porque póde o Principe ser asaltado de improvizo, e perder o estado antes que possa formar exercito para rezistir, ou póde perder a batalha e com ella o estado por não ter onde se retirar, e defenderse athe fazer novas levas, e novo exercito.

Ao exemplo dos Romanos, e outros Principes que desmantelarão muytas praças se responde, que o fizerão por serem muytas em numero, e não havendo bastante gente para guarnecer a todas, ou não sendo conveniente prezidialas, foy sabio conselho o mandalas demolir, não sendo boa politica deyxalas fortalecidas em poder de nações estranhas, e conquistadas por força.

Se El Rey de França desmantelou Arrochela foy so pela banda de terra, mas pela do mar donde ficava mais exposta ao inimigo externo a deyxou fortificada.

Se os Polacos reprovão as fortificações não he porque deyxem de conhecer a sua utilidade, mas fundados em que o seu Reyno he de eleyção, e cada hum daquelles nobres aspira a ser rey, por tanto receandose que por meyo das praças fortificadas algum dos Reys eleytos se faça hereditario, e perpetue o reinado na sua descendencia pondo por governadores e cabos dos prezidios pessoas de sua confiança, e obrigação não querem fortalezas. Porem que roim conselho seja este o mostra bem a experiencia, porque daqui rezulta estar o paiz aberto, e exposto ás continuas correrias, e invazões dos Turcos, e Tartaros, que todos os annos levão hu'a grande quantidade de cativos, penetrando livremente o paiz, como fizerão o anno de 1682 chegando athe Leopoli cidade principal da Russia, 
fazendo mais de 8 mil escravos, donde nasce estar hoje dezerta por este respeyto toda a Podolia, e toda a Ukrania provincias grandes, e de summa fertilidade.

Mas para que he necessario cançar em provar hu'a couza tão clara, e tam aprovada de todas as mais politicas nações de Europa.

O Emperador de Alemanha, os Reys de França, Espanha, e Portugal, as Respublicas de Veneza e Holanda, e outros Principes Menores todos tem fortalezas para segurança de seus estados, e he certo que se não moverão todos estes Principes a fabricar fortalezas fazendo nellas tam grande dispendio por inconcideração, ou más conselho, porque todos são assistidos de conselheyros prudentissimos, mas pella manifesta utilidade que das praças fortificadas rezulta a seus estados.

Cap. $^{\circ} 3 .^{\circ}$

SE HE MELHOR FORTIFICAR AS FRONTEYRAS

\section{$\mathrm{OU}$ \\ O MEYO DO ESTADO}

Havendo discorrido no Cap. ${ }^{\circ}$ antecedente se vem as fortalezas uteys a todos os Príncipes; antes de passar adiante parece conveniente rezolver se se devem fortificar antes as praças fronteyras, ou as do coração do estado, porque nisto ha diversos pareceres.

Dizem os que querem fortificar as fronteyras, que fortificandose estas não podem os inimigos entrar no paiz de seu adversario, sem primeyro as expugnar, não sendo boa razão de estado, e de guerra deyxar atras praças fortes, e prezidiadas, e q' 
em quanto o inimigo se occupa, e detem em as sitiar, tem o Principe tempo, e commodidade de unir suas forças, receber socorros dos amigos, e aliados, e opporse ao inimigo, ou divertir a guerra intrando no paiz contrario, como fizerão os Romanos que para arrancar a Anibal de Italia onde havia 16 annos que a custa das provincias Romanas fazia a guerra, mandarão a Cipião fazer o mesmo em Africa. Acrescentão que estando as fortalezas no meyo do estado entra o inimigo livremente nelle, nem dá tempo, ou comodidade ao Principe de poder juntar suas forças, de que rezulta, que ficando o inimigo senhor da campanha brevemente se fará tambem senhor das fortalezas, e de todo o estado.

Os que aprovão fortificar o meyo do paiz dizem que deficultozamente se póde prohibir em hum estado grande, e aberto com pouco numero de fortalezas, que hum poderozo inimigo não entre no meyo delle por entre hu'a e outra fortaleza, e que o fabricar e sustentar muytas nos confins he couza de grandissima despeza, assim em as edificar, como em as guarnecer, porque isto pede de continuo hum exercito que as guarde, o que não póde fazer se não hum Principe $\mathrm{m}^{\text {to }}$ poderozo; pello que melhor seria manter continuamente hum exercito em campanha, que tello fechado, e desunido em muytas fortalezas; porque entrando hum poderozo inimigo em hum estado, posto que as fronteyras delle estejão fortificadas, vive com tudo da substancia do mesmo estado; andando forrageando ${ }^{8}$ pellas villas, e lugares abertos com groça escolta, por não serem bastantes as guarnições das praças desunidas, a impedilo: mas no cazo que as guarnições se unão para este

\footnotetext{
${ }^{8}$ O sentido deve ser o mais amplo da palavra, isto é devastando, recolhendo víveres e não somente ceifar a forragem.
} 
effeyto encorrem em dous perigos grandes, que ou no caminho podem ser rotos, e desfeytos; ou deyxando as praças mal providas, e mal guardadas dão occazião ao inimigo de as tomar facilmente. Acrescentase que as fortalezas das fronteyras sam mais faceys de se tomar, que as do coração do estado.

Para rezolução desta duvida se deve primeyro conciderar a qualidade e estado do Principe que quer fortificar; porque sendo poderozo, e tendo outro vezinho mayor, ou igual, a este não só está bem fortificar as fronteyras, mas tambem huma cidade no meyo do dominio, que será de razão seja aquella onde fizer rezidencia, e tiver a sua corte. Verdade he que o Principe tendo fortificada a fronteyra escuza de manter prezidio na corte em tempo de paz, mas nella deve de conservar toda a sorte de monições de guerra, e de vivres para poder accodir na occazião a todas as outras fortalezas do seu estado, servindo a corte como de cabeça, e coração a todas as outras: e a razão he, porque se o Principe não tivesse fortaleza no meyo do estado, sendo o inimigo senhor da campanha, poderia entrar nelle, e lançalo fora da corte, de que rezultaria hu'a grandissima confuzão, e talvez a roina de todo o estado; e se bem o Principe acometido tivesse exercito em campanha, nem por tanto estaria de todo seguro, porque hum exercito esta sugeyto a mil accidentes diversos, e estranhos, e qualquer couza levissima faz perder hu'a batalha.

Nem he boa razão dizer que o exercito se não exporá a risco de dar batalha, porque esta muytas vezes se não póde escuzar sem manifesta roina: assim sucedeo aos Venezianos no anno de 1509 quando Bartholameo [sic] Alviano seu general sem ordem da Republica attacou a batalha com os Francezes em Ghiara de Adda na qual foy roto e prezo, porque perderão então os Venezianos 
todo o dominio da terra firme, e se a cidade de Veneza não estivera posta em tão forte sitio, corria perigo de perder então a sua antiga liberdade.

Nem alguem se deve fundar sobre aquella antiga sentença, que ninguem hindo a conquistar hum paiz deve deyxar atras algu'a praça forte, porque muytas vezes os Cap. ${ }^{\text {es }}$ prudentes não observão esta maxima, como fes Franc co $1^{\circ}$ Rey de França que hindo a conquistar o ducado de Milão deyxou atraz as cidades de Novara, Pavia, e Dertona, e se foy direyto a cidade de Milão cabeça do estado. O mesmo fes o gran Vizir quando veyo sitiar Viena, o anno de 1683, deyxando atraz Savarino, e Comora, praças fortes e prezidiadas. Tambem o Duque de Lorena no anno de 1684 foy sitiar Buda deyxando atraz Neuheuzel, na qual se acharão muytos officiays Engenheyros Portuguezes mandados pello serenissimo Senhor Rey Dom Pedro de saudoza memoria no anno de 1685 a 19 de Agosto dia em q' foy gloriozamente vencida por assalto, sendo mortos quantos erão dentro, que serião perto de 4 mil almas, em que entravão 1500 soldados Turcos. Pello contrario Anibal em querer conquistar algumas forças dos Romanos nos confins de Espanha, deu tempo ao Senado a se preparar para a defença; e se houvesse hido em direytura a Italia sem deterse os sugeytaria sem duvida. Assim que pelas razões sobreditas se conclue ser conveniente a hum Principe, por grande que seja, fortificar não só os confins, mas ter tambem hu'a praça forte no meyo do seu estado.

Mas se falarmos de hum Principe de mediana potencia, ou estado, digo que a este importa mais fortificar algum lugar no meyo do estado, excepto se a entrada no seu paiz for dificultoza, a saber, estreyta entre montes, ou defendida de 
algum grande lago, ou mar, de sorte que com duas ou tres fortalezas ao mais possa prohibir aos inimigos a entrada; porque em tal cazo deve tambem fortificar estes passos; mas em paiz plano, e aberto he melhor fazer hu'a so fortaleza, ou duas ao mais grandes e fortes no meyo do estado; porque hum inimigo rezolvendose a accommeter outro, mais facilmente o fará vendo as forças de seu contrario repartidas em muytas praças, do que unidas em hu'a só, e grande; porquanto para sitiar hu'a fortaleza mediocre, mediocres forças bastão; mas para pôr sitio a hu'a praça grande são necessarias forças grandissimas: e porque as fortalezas e cidades grandes são sugeytas ordinariamente á falta de viveres, deve aquella praça estar sempre muyto bem monicionada, e em occazião de guerra se devem a ella recolher todos os mantimentos do paiz, queymando os que se não puderem conduzir para privar delles ao inimigo ${ }^{9}$.

\section{Porem discorrendo sobre hum Principe pequeno, digo que} pouco importa a este fortificarse mais na fronteyra que no meyo do estado, e que somente deve escolher algum sitio por natureza forte para o ajudar com a arte, e tratar de fazer nelle hum castello, ou praça de confiança, para em cazo de aperto, e necessidade poder recolher nelle as couzas mais preciozas, ficando elle fora para procurar o socorro; não convindo de nenhu'a sorte a os pontentados [sic] deyxarse enserrar em hum lugar, por não correr perigo de perder com a fortaleza o estado, e a vida, como sucedeu a Lodovico Sforça quando se deyxou sitiar em Novara, porque com a praça perdeu o estado, e a liberdade, sendo entregue, e vendido pelos Suizeros quando sahia entre elles com hu'a pica ás costas em trage de Tudesco.

\footnotetext{
${ }^{9}$ Esta técnica de terra arrasada foi um expediente muito utilizado desde o passado até bem recentemente, porque dificultava o fornecimento logístico dos exércitos invasores, especialmente quando os sistemas de transportes eram mais lentos e as distâncias grandes. Os russos usaram o procedimento com muito sucesso na invasão do seu país pelas tropas napoleônicas.
} 


\section{$\operatorname{Cap}^{\circ}{ }^{4} .^{\circ}$ \\ DA QUALIDADE DOS SITIOS \\ E QUAIS SÃO MELHORES PARA SE \\ HAVEREM DE FORTIFICAR}

Sendo o sitio hu'a das principays circunstancias a que deve atender quem houver de fortificar huma praça, discorreremos neste $\mathrm{Cap}^{\circ}$ sobre esta materia da qual tratão largamente Antonio de Ville ${ }^{10}$ liv. $1^{\circ} \mathrm{Cap}^{0} 4^{\circ}{ }^{\circ}$, Mathias Dogen ${ }^{11}$ liv. $2^{\circ} \mathrm{Cap}^{\circ} 13$, Simão Estevino ${ }^{12}$ questão $6^{\text {a }}$ e outros, ponderando os commodos, e incommodos que dos sitios rezultão; os quais em geral se podem reduzir a seis sortes, a saber sobre montanha, ou rochedo, campanha raza enxuta ou alagadiça, dentro de alguma ilha, ou peninsula.

${ }^{10}$ O Cavaleiro Antoine De Ville (1596-1657) foi um profissional que dedicou a sua vida às artes da guerra, tanto na construção quanto na expugnação de praças. De distinta $e$ tradicional família de militares, era considerado como engenheiro e arquiteto militar, tendo iniciado o seu estudo da matéria através do tratado de Errard de Bar-le-Duc. Era um experto em minas, um procedimento muito corriqueiro para auxiliar na tomada de praças e, como tal, participou em muitos assédios importantes. Do seu currículo consta o serviço prestado à República de Veneza entre os anos 1630 e 1635, quando fortificou a cidade de Pola. Quando voltou de Veneza, esteve a serviço de Richelieu. Em 1636, estava lutando em Flandres com o Conde de Soissons; em 1637, nos assédios de Corbie e Landrecy e, em 1639, no assédio de Hesdin. Era um militar extremamente ativo e muito da sua experiência adquiriu nos campos de batalha. Foi escritor muito prolífero, mas vamos destacar somente o seu trabalho mais alentado sobre as fortificações: Les Fortifications, conhecido em outras edições como Les fortifications ou l'ingénieur parfait. O seu método de fortificar é conhecido como o mais característico da Escola Francesa de fortificação do seu tempo.

${ }^{11}$ Matthias Dögen (1605-1672), estudou em Leiden e trabalhou no quartel general do almirantado em Amsterdã. Embora não se conheça a sua atividade como fortificador, o seu tratado adquiriu enorme prestígio seguindo o mesmo sistema de Marolois e Freytag. Houve edições quase simultâneas do texto em latim (1647) e em francês e alemão (1648). O nosso Serrão Pimentel faz muitas referências a este texto.

${ }^{12}$ Simon Stevin era de Bruges e foi um dos primeiros tratadistas dos Países-Baixos de importância. A sua obra técnica situa-se no final do Século XVI e início do XVII. Foi matemático, engenheiro do Príncipe de Orange e fortificador dos Estados da Holanda. Seu trabalho mais antigo, segundo Marini, foi Starckten Bauwing datado de 1594. Mais tarde escreveu Nieuwe maniere van Sterck bouwen door spilsluysen editado em Roterdam, em 1617 e Leiden, em 1618. 
Sobre qual destes seja melhor para se fortificar ha diversos pareceres, alegando cada hum pella sua parte as razões seguintes.[:]

Aquelles que poem em primeyro lugar as praças fortes sobre montanhas e rochedos alegão.[:]

$1^{\circ}$ Que estas praças não podem ser minadas.

$2^{\circ}$ Que gozão de hum ar puro e saudavel.

$3^{\circ}$ Que o inimigo se the não póde acostar com facilidade, por ser descuberto de longe, e poderselhe impedir a chegada com artelheria.

$4^{\circ}$ Que as montanhas são per si mesmo tão fortes que custa pouco ajudar a natureza com o artificio, fabricando os baluartes, e mais obras da fortificação com pouca despeza.

Porem contra estas mesmas praças se the oppoem o seguinte[:]

$1^{\circ}$ Que raras vezes se achão fontes sobre os rochedos, donde procede a falta de agua sem a qual se não póde viver.

$2^{\circ}$ Que custa muyto a conducção dos bastimentos, monições, e tudo o mais necessario para a fortificação: assim tambem em tempo de sitio he difficultoza a retirada quando os de dentro fação algu'a sortida, poys antes que se recolhão tem que subir a altura do monte, onde serão descubertos, e podem se accometidos.

$3^{\circ}$ Que a terra em semelhantes lugares não he ordinariamente boa para os parapeytos, por ser area, ou saibro; nem a forma que a natureza deu a estes lugares se póde facilmente mudar por arte, por ser pela mayor parte irregular; e succede que por esta mudança arteficial sahe a fortificação mayor, ou mais pequena do que convem: 
As comodidades das praças em campanha raza são as seguintes.[:]

$1^{\circ}$ Que a terra comummente he boa, e unida, e por tanto muyto cómoda para a fabrica das obras da fortificação.

$2^{\circ}$ Que são ordinariamente abundantes de agoa, ou de fontes, ou de possos.

$3^{\circ}$ Que ordinariamente as campanhas são ferteys e por tanto se podem recolher dentro da praça com facilidade os viveres sem ser necessario conduzilos de longe.

$4^{\circ}$ Que póde o Engenheyro dar a forma que the parecer á praça fazendo-a regular ou muyto proxima á reguralidade [sic].

$5^{\circ}$ Que vindo o inimigo alojar-se á roda de huma tal praça, e atacandoa vivamente, ha nella mais cómodidade de fazer cortaduras, e retiradas.

Os incomodos destas praças são[:]

$1^{\circ}$ Que o inimigo goza das mesmas cómodidades q' os da fortaleza, porque se a terra he boa servirseha della para as batarias, reductos, e semelhantes obras, tambem como os da praça, e com mais facilidade abrira nella os aproxes.

$2^{\circ}$ Que póde tambem escolher hu'a figura commoda para circunvalar seu campo sem grande trabalho, e sem muyta despeza.

$3^{\circ}$ Que póde atacala fortemente por todas as partes.

$4^{\circ}$ Que póde melhor gozar dos fruytos de hum paiz fertil, do que os sitiados, que não podem sahir a recolhelos. 
O sitio em paul goza os previlegios seguintes.[:]

$1^{\circ}$ Que se não póde atacar com trincheyras subterraneas, e o querelas fazer sobre hum sitio alagadiço conduzindo a terra e fachina de longe he acção muy dilatada, e de muyto custo. $2^{\circ}$ Que o inimigo não póde conduzir sua artelheria sobre hum tal sitio por cauza da pouca firmeza, e sem ella the não póde tirar as defenças dos flancos, e menos arruinarlhe, e desfazerlhe os reparos.

$3^{\circ}$ Que necessita de menos gente para se guardar, e defender a respeyto das poucas chegadas que o inimigo tem para a praça.

Pello contrario tem os seguintes incomodos.[:]

$1^{\circ}$ Que ordinariamente as aguas não são sadias, e cauzão muytas doenças: assim mesmo os ares por cauza dos vapores das aguas encharcadas, que facilm ${ }^{\text {te }}$ se corrompem, o que tudo se verte contra os moradores, fazendo adoecer e morrer muytos soldados, sem os quais se não defende a praça. $2^{\circ}$ Que posto necessitem de menos reparos, com tudo estes custão muyto por cauza do roim fundamento.

$3^{\circ}$ Que facilmente se lhe podem serrar, e impedir as estradas para the estorvar a condução dos vivres, e socorros.

Os sitios junto da agua, como dentro de hum lago, ou rio, dentro do mar junto da terra firme, tem as seguintes ventagens.[:]

$1^{\text {a }}$ He necessario que o inimigo sitie estas praças tanto por mar como por terra, o que the he muyto dificultozo, tanto pelas grandes despezas, quanto pellas grandes incomodidades a que está exposto. 
$2^{\text {a }}$ Podem-se conduzir todas as monições por agua, com muyta facilidade, e menor despeza.

$3^{\text {a }}$ Não podem ser batidas em brecha com artelheria porque do mar para a terra se não atira seguramente, por cauza do perpetuo movimento.

$4^{\text {a }}$ Nem são necessarias grandes despezas para se fortificar, porque a agua dificulta a chegada, nem tão pouco necessitão de muyta guarnição.

Tem com tudo as oppozições seguintes.[:]

$1^{\text {a }}$ Que hu'a tal fortaleza he de pouco serviço quando ella não póde dar socorro ao paiz.

$2^{\text {a }}$ Que: posto que se lhe não possa chegar com facilidade com tudo necessita o inimigo de pouca armada para os ter em sitio. $3^{\text {a }}$ Que os de dentro necessitão igualmente de armarse com embarcações, a fim de ter sempre a passagem livre para que a provizão the não falte.

Mas nesta variedade havendo de eleger e preferir algum sitio aos outros, digo que para huma praça real, e grande, que sirva de segurar o paiz, e fazer oppozição a hum exercito, e detello em quanto se não ajunta poder que se lhe opponha, he melhor hum sitio moderadamente elevado sobre a campanha raza, e tanto melhor se tiver algum rio que lhe passe junto pelo qual se possão com menos despeza conduzir as monições, e tudo o mais de que necessita hu'a praça de armas, como Viena de Austria na Ungria ${ }^{13}$.

\footnotetext{
${ }^{13}$ Na época tratava-se do Império Austro-Húngaro.
} 
Para hu'a fortaleza pequena que so sirva de se guardar a si mesma para impedir a entrada em algum paiz será melhor o sitio sobre algum rochedo, e este será tanto melhor quanto for mais alto, que a elle se não possa subir, mais que por hu'a estrada estreyta, e embaraçada, como Evoramonte no Alem Tejo.

Tambem se póde estimar o sitio em paul, quando nelle haja algum lugar elevado, e commodo para se fortificar, sem embargo das oppozições que the são feytas, porque em quanto á corrubção [corrupção] das aguas se póde remediar fazendo esgotar o fosso a miudo, e enchelo de nova agua fresca, procurando para este effeyto fazerlhe os canays commodos, e mudar a miudo a guarnição pelo perigo das doenças; a praça de Neuheusel em Ungria.

O sitio em ilha será melhor quanto esta for mais pequena, de sorte que a fortificação a occupe toda, de modo que o inimigo não possa ter lugar em terra para se alojar, fazer aproxes, e bater a praça.

O sitio em peninsula será melhor o que tiver a entrada da terra firme mais estreyta, e que tenha com tudo capacidade dentro, e junto algum porto para ter embarcações de guerra com que possa segurar o mar, e infestar os portos dos vezinhos, e tambem lograr o proveyto da mercancia. Estas conveniencias todas ainda com outras ventagens particulares tem o sitio e villa de Peniche na provincia da Estremadura cuja fortificação sendo acabada de todo se reputa na opinião de muytos por hu'a das mais fortes da Europa. Tambem o sitio de Sagres no reyno de Algarve se tivera melhor porto, e não padecera falta de agua, (a qual porem se póde remediar) se póde estimar por hu'a fortaleza inexpunavel, falando moralmente. 
Não são ociozas de tudo estas consideraçoens, posto que ordinariamente sejamos hoje obrigados a accomodarmonos com o sitio tal qual foy a eleyção dos primeyros habitadores, poys ordinariamente so se tratão de fortificar as cidades, e villas antigas, e ja habitadas, e não fundar outras de novo; mas porque alguma vez succederá nas conquistas deste reyno ser necessario fundar novas povoações, ou alguma nova fortaleza para segurança dos portos das mesmas conquistas como não ha muytos annos se mandou fundar a nova Colonia do Sacramento no Rio da Prata, e outras em outras partes, e em semelhantes cazos por concluzão aquelle sitio será melhor para se fortificar que tiver as qualidades seguintes, ou a mayor parte dellas.[:]

$1^{\text {a }}$ Que seja de bons ares, e abundante de boas aguas nativas, e em falta de possos, porque os de máos ares e roins aguas são sepultura dos habitadores, e soldados, estando sempre o Principe em hu'a continua perda de gente, e de cabedal ${ }^{14}$.

$2^{\text {a }}$ Que o terreno do contorno seja fertil para poder sustentar o prezidio, e crescer o concurso dos habitadores.

$3^{\text {a }}$ Que o lugar que se houver de fortificar não seja sugeyto a eminencia donde possa ser batido com artelheria ${ }^{15}$.

$4^{\text {a }}$ Que nelle haja boa terra para a construcção dos terraplenos, e parapeytos.

$5^{\mathrm{a}} \mathrm{E}$ a mais principal que seja em tal lugar que faça conseguir ao Principe o intento com que a manda fortificar: que

\footnotetext{
${ }^{14}$ Conceito vitruviano do Livro I: Da escolha dos lugares sadios.

${ }^{15}$ É o famoso padrasto referido nos textos (tratados, relatórios, pareceres etc.) sobre engenharia, definido por Azevedo Fortes como: Padrasto ordinário se chama qualquer oiteiro visinho à Praça, do qual póde ser batida com Artelharia.
} 
se for para segurança de algum porto se deve mais que tudo atender a eleger posto do qual se possa fazer muyto danno a todas as embarcações que quizerem cometer a entrada.

Se for para ter em obediencia alguns povos se deve eleger posto que facilmente possa ser socorrido no cazo de alguma rebelião.

Se for para ter entrada em algum paiz se deve eleger paragem que a ofereça por parte menos embaraçada com rios, ou com montanhas.

E porque podem ser muytos outros e varios os intentos, deve o Engenheyro ser muyto circunspecto e pervisto para saber bem informar ao Principe, e aos seus menistros do conselho de estado e guerra, a quem toca a diliberação dos lugares que se devem fortificar.

Engenheyro chamão hoje todas as nações politicas ao architeto das fortificações, nome que the derão os peritos da arte melitar, porque com engenho e industria faz tanto serviço nas funções da guerra, quanto os outros soldados com o valor do animo, e forças do corpo.

Deve por tanto ser dotado de hum sublime engenho, e em primeyro lugar deve saber geometria, porque sem ella não poderá dar razão solida da suas operações: deve saber Arithmetica para saber dar razão da somma das despezas; deve saber riscar, porque seria couza vergonhoza não poder mostrar ao seu general a planta da futura obra: deve juntam ${ }^{\text {te }}$ ter noticia da architectura sevil [sic], para saber ordenar as fachadas dos portays; as pontes, os quarteys, os armazens, e outras couzas que são mais proprias desta architectura que da melitar; deve ter noticia da mecanica para sa- 
ber conhecer a força de quaisquer instrum ${ }^{\text {tos }}$, e sabellos aplicar quando the seja necessario ${ }^{16}$.

Deycho outras muytas e boas qualidades que deve ter hum Engenheyro; finalmente deve ser valerozo, porque como nos sitios das praças he sua obrigação traçar as trincheyras dos aproxes, as praças de armas, as galarias, os alojamentos sobre a contraescarpa, e conduzir estes trabalhos athe o pê das muralhas da praça opugnada; e estando dentro della he sua obrigação ordenar as cortaduras, e todas as mais obras que se fazem para reparar a brecha, e prohibir o asalto o que tudo se não faz sem hum grande risco de sua pessoa.

\section{$\mathrm{Cap}^{\circ} 5^{\circ}$ \\ DAS MAXIMAS GERAES DA FORTIFICAÇÃO}

Havendo discorrido no Cap. ${ }^{\circ}$ antecedente das qualidades dos sitios, e quais sejão melhores para se fortificarem seguese dizer das qualidades que deve ter hu'a boa fortificação, cuja perfeyção consiste nas seguintes maximas em que todos uniformem ${ }^{\text {te }}$ hoje concordão ensinados da experiencia nos attaques, e defença de varias praças.

$1^{\text {a }}$ Que não haja lugar algum em toda a fortificação q' de outra parte della não seja descuberto e flanqueado pelos defensores ${ }^{17}$. A razão he porque se houver lugar que não seja flanqueado, nelle se poderá o inimigo encubrir em grande perjuizo da praça de que segue a [2a $]$.

\footnotetext{
${ }^{16}$ Ensinamentos dentro do espírito vitruviano, quando fala das coisas que deve saber o arquiteto no Livro I.

${ }^{17}$ Outra vez a demonstração da imperiosa necessidade do flanqueamento.
} 
$2^{\text {a }}$ Que a fortificação deve ter tal forma que cada huma de suas partes alem da defença direyta que de sy fazem, recebão outra lateral, ou obliqua das outras partes, pelo que cada hu'a deve defender, e ser defendida.

$3^{\text {a }}$ Que a fortificação tenha força igual por todas as partes, a razão he porque se houver algu'a menos forte esta será a accommetida com dáno e perda de todas as mais, de que se segue.

$4^{\mathrm{a}}$ Que a fortificação regular deve ser preferida a irregular; a razão he por ser igual por todas as partes: alem de que fica a praça mais capaz sem mayor gasto, poys das figuras do mesmo ambito a regular he a mais capaz.

$5^{\mathrm{a}}$ Que a fortaleza domine todos os lugares arroda della; a razão he porque de outro modo estarião os defensores menos seguros tendo o inimigo lugar de donde poder infestar o interior da praça.

$6^{\text {a }}$ Que as partes interiores que servem de retiradas sejão mais altas, de modo que dominem as exteriores; a razão he, porque se estas fossem iguais, ou mais altas, sucedendo que o inimigo as ganhase ficaria igual, ou com ventagem [vantagem] aos da praça.

$7^{\text {a }}$ Que as obras exteriores, e mais afastadas do centro da praça sejão descubertas pella parte interior sem parapeyto, ou reparo algum defensivo a os tiros das obras proximas, a razão he porque se o inimigo as ganhar, não fique cuberto contra a praça.

$8^{\text {a }}$ Que todas as partes da fortaleza sejão capazes de resistir ás armas e maquinas do inimigo, das quais hoje a mais forte, e violenta he o canhão; a razão he, porque sendo mais fracas 
as desfará facilmente com a bataria, e ficarão os defensores expostos, e descubertos aos tiros.

$9^{\text {a }}$ Que os baluartes sejão capazes de receber sufficiente numero de defensores, e que tenhão bastante praça para o manejo da artelheria, e mais funções melitares, especialmente para as cortaduras.

$10^{\text {a }}$ Que todas as partes da fortificação tenhão suficiente grandeza, com hu'a uniforme conrespondencia entre sy, de tal modo que nenhu'a se aumente com detrimento da outra ${ }^{18}$.

Mas qual deva ser esta conrespondencia entre as partes da fortificação he toda a duvida entre os Engenheyros; discorreremos em seus lugares sobre cada hu'a dellas em particular, e referiremos as opiniões de muytos autores.

\author{
$\operatorname{Cap}^{\circ} 6^{\circ}$ \\ DOS NOMES DAS LINHAS, E ANGULOS \\ DA FORTIFICAÇÃO NO QUE TOCA A \\ EXPLICAÇÃO DA PLANTA IGNOGRAFICA
}

Tres são os modos porque se explica a despozição ${ }^{19}$ de qualquer dezenho, assim na architectura sevil, como tambem na melitar, a saber ignografica a qual he a plana reprezentação de toda a obra da fortificação sobre o plano horizontal.

\footnotetext{
${ }^{18}$ Ensinamentos contidos na euritmia, simetria e decoro de Vitrúvio explicadas no Livro I.

${ }^{19}$ Do dispositio vitruviano contido no Livro I: A disposição éo arranjo conveniente de todas as partes de sorte que colocadas segundo a qualidade de cada uma formem um conjunto harmonioso. As espécies de disposição, chamadas em grego "idéias", são o traçado em planta, em elevaçãoe em perspectiva (Iconografia, Ortografia e Cenografia).
} 
Ortografia, ou perfil he a reprezentação do vale e fosso cortado em angulos rectos por hum plano perpendicular ao dito vale e fosso.

Scenografia chamada vulgarmente prespectiva [sic], he a pintura da futura obra como aparecerá a quem a vir de algu'a certa distancia.

Neste $\mathrm{Cap}^{\circ}$ dizemos os nomes das linhas e angulos pertencentes a explicação da planta ignografica (das outras se dirá em seu lugar) e são as seguintes.[:]

Fig. ${ }^{a}{ }^{a}{ }^{a}$ [Est.1] GG lado do poligono interior.

GN demigola ${ }^{20}$.

NQ gola legitima, ou gocier ${ }^{21}$.

NN cortina.

NR flanco primario, ou flanco recto.

NY flanco secundario, ou flanco oblico.

YN complemento da cortina.

XR face.

XN linha fechante.

XRY linha razante.

RY continuação da face.

XX lado do poligono exterior.

$\mathrm{XZ}$ sobre face.

NZ flanco prolongado.

\footnotetext{
${ }^{20}$ Demigola seria o segmento QG ou então o GN da Fig. 2, Est. 1 dos desenhos de Vellozo.

${ }^{21} \mathrm{O}$ uso de termos originários de outras línguas era muito comum entre os tratadistas portugueses quando se tratava de fortificações. Alguns eram usados ipsis literi, outros aportuguesados na sua grafia. A maior influência era do francês e do italiano, mas havia até termos de origem holandesa como hornaveque. Mas, voltando para o significado específico da palavra gola podemos dizer que é a garganta ou entrada do baluarte que fica delimitada pelo encontro das duas cortinas laterais ao baluarte.
} 
RZ extenção do flanco.

GX capital.

XA semediametro [sic] mayor.

GA semidiametro menor.

Angulos

XAX angulo do centro.

ZXZ angulo do poligono exterior.

GGN angulo do poligono interior.

RXR angulo flanqueado ${ }^{22}$.

XRN angulo da espalda.

RNY angulo flanqueante.

RYN angulo flanqueante interior, ou angulo da razante e cortina,

RFN angulo flanqueante exterior, ou angulo da tenalha.

A face, flanco, e cortina são só as tres linhas que se fazem realmente de muralha, e com as quais se forma o recinto de toda a fortificação: as mais são imaginarias, mas sua contemplação concorre muyto para inteligencia da conrespondencia que devem ter as ditas tres face, flanco, e cortina, como se verá nos discursos seguintes.

${ }^{22}$ Quando a fortificação é regular a bissetriz do ângulo flanqueado corresponde à linha capital. 


\section{$\operatorname{Cap}^{\circ} 7^{\circ}$ \\ DO MODO DE TIRAR A PLANTA DO TERRENO PARA ASSENTO DA FORTIFICAÇÃO.}

Toda a fortificação assenta sobre alguma figura geometrica; a eleyção desta figura pertence particularmente ao Engenheyro: nas campanhas razas, e livres he facil de accommodar qualquer que the parecer; porem nos sitios irregulares, e com altos e bayxos pende [depende] esta eleyção da dispozição do tal terreno, e aqui he que se ve a boa eleyção e pratica do Enginheyro; deve por tanto primeyro que tudo tirar a planta do sitio, e descrevelo em hum papel com todas as suas circunstancias para melhor examinar e julgar se he capaz de hu'a fortificação regular, ou se deve ser fortificado irregularmente.

Para este exame se necessita de algum instrum ${ }^{\text {to }}$ dos em que ja falamos na planemetria em que se possão medir, e hu'a cadea de arame dividida por humas argolinhas de dez em dez palmos ou pês; o que assim preparado se signalarão com balizas todos os angulos que tiver a figura natural do terreno, que supponhamos he o exagono irregular

Fig $^{a} 3^{a}$ Est. 2 AXYZRG $^{23}$ da qual se fará hum rascunho ainda que tosco em hum papel que servirá de memorial para nelle se escreverem as medidas que se tomarem, o que assim feyto se armará o instrumento em qualquer dos angulos da dita figura signalada, como por exemplo no angulo A, e olhando pellas pinolas para as duas balizas dos dous angulos $\mathrm{G} \mathrm{e}$ mais $\mathrm{X}$ o instrumento mostrará de quantos graos he o dito angulo $\mathrm{A}$,

\footnotetext{
${ }^{23}$ É bom que se chame a atenção para o fato de que este polígono deve ter sido executado com transferidor e em uma escala não muito precisa, de modo que quando colocamos os valores dos segmentos de retas e ângulos internos indicados em uma ferramenta computacional como o AUTOCAD aparecem algumas diferenças de ângulos e de tamanho de linhas.
} 
os quais se assentarão no memorial ou rascunho, e logo se midirão os lados AX, e AG com a cadea: feyto isto se mudará o instrumento para $\mathrm{o}$ angulo $\mathrm{X}$, e olhando pellas pinolas do instrumento para as balizas do angulo $\mathrm{A}$, e do angulo $\mathrm{Y}$ se assentarão os graos que o instrum ${ }^{\text {to }}$ mostrar pelo valor do dito angulo $X$, e dahi com a cadea se medirá o lado XY: da mesma sorte se medirá o angulo $\mathrm{Y}$, e os mais angulos, e tambem os outros lados, o que assim feyto se descreverá a figura no papel bem ajustada, e semelhante á do terreno por meyo de hum semicirculo de lamina transparente, ou de latão ${ }^{24}$ aberto no meyo, descrevendo por elle os angulos no papel do mesmo numero de graos, ou graos e minutos notados em lembrança; os lados se medirão no papel por hu'a linha dividida em partes iguais a que chamão escalla, ou petipê $\hat{e}^{25}$, a qual representará o mesmo genero de medidas que forão tomadas no terreno, como por exemplo palmos, pés, ou braças, como se ve dentro da mesma figura o petipe EF.

Para se saber se os angulos forão bem tomados da somma de tantas vezes 180 graos quantos são os lados da figura se tirem 360, se o que restar for igual a somma de todos os angulos achados no instrumento será a operação bem feyta; se a diferença for de pouco momento como de 30 minutos, ou athe 2 graos em hu'a figura de muytos lados se repartirá esta diferença igualmente por todos os angulos, mas se houver diferença de consideração será necessario tornar a repetir a operação em cada hum dos angulos, ou ao menos naquelles onde se tiver mayor escurpulo [escrúpulo] para se conhecer donde foy o erro ${ }^{26}$.

\footnotetext{
${ }^{24}$ Transferidor atual.

${ }^{25}$ É o que nós designamos atualmente por escala gráfica do desenho.

${ }^{26}$ Nestas considerações sobre o erro admissível na medição de ângulos notamos que o autor aceita uma variação entre 0,5 a $2^{\circ}$. Estes limites são por demais dilatados para os levantamentos atuais, mas perfeitamente admissíveis para os instrumentos rudimentares da época, quando as visadas eram feitas através de pínulas nos aparelhos.
} 
Se a figura tiver algum angulo exterior, como por exemplo o Angulo A no exagono proposto, se ajuntarão em hu'a somma todos os angulos internos, e a esta somma se ajuntará o complemento do angulo exterior para 360 graos, e porque no sobredito exagono.

o angulo $\mathrm{X}$ foy achado de 83 graos

o angulo $\mathrm{Y}$ de 120

o angulo $\mathrm{Z}$ de outros 120

o angulo $\mathrm{R}$ de 102

o angulo $\mathrm{G}$ de 92

cuja somma he 517

á qual ajuntando 203 que he o complemento do angulo A para 360 graos, somma tudo 720 que he o que devem importar os angulos de qualquer exagono, pello que entenderemos que estes forão bem tomados; a demonstração desta regra se colhe do scholio ${ }^{27}$ da prop. 32 do liv. $1^{\circ}$ de Eúclides.

E não só deve o Engenheyro ser solicito em medir todos os lados e angulos, com muyta exacção, mas deve aplicar toda a deligencia para que lhe não fique couza alguma de importancia assim dentro como fora da figura que ha de fortificar, a qual não seja por elle bem reconhecida: dentro da figura tratando da fortificação de alguma cidade deve deligniar na planta as partes, portas, diques e couzas semelhantes; e fóra da figura todos os lugares circumvezinhos, aquedutos, pauys, estradas, quintas, bosques, e outras couzas desta qualidade, para que revistas todas com cuydado, e com prudencial juizo fique facil ajudar com a arte aquillo que

\footnotetext{
${ }^{27}$ O termo escólio, que, como se sabe, significa explicação ou esclarecimento faz parte da estrutura de muitos tratados de engenharia militar, onde estes esclarecimentos são colocados com destaque no texto.
} 
póde servir para a defença, e regeytar, ou emmendar o que puder ser de perjuizo, e assim tambem mais facilmente reconhecer que figura póde accommodar, ou regular, ou mais proxima a regularidade, a qual outra vez tornará a conferir sobre o terreno para evitar de novo algum inconveniente que não fosse advertido ao principio; nem se deve cançar de tanta cautella, poys na primeyra eleyção da figura está a mayor parte do acerto e propriedade da fortificação.

Para asignar no papel as couzas que houver mais notaveys servirá tambem o instrumento; para notar por exemplo a Igreja $\mathrm{Y}$ [I] se medirão os angulos ZRY, RZY, os quais com o semicirculo se descreverão no papel de outros tantos graos quantos mostrar o instrumento, e onde se cruzarem as linhas ZY e RY será o sitio da Igreja; da mesma sorte medindo os angulos $\mathrm{YZO}, \mathrm{ZYO}$ onde se cruzarem no papel as linhas $\mathrm{ZO}$, e $\mathrm{YO}$ sera o lugar do monte $\mathrm{O}^{28}$ : semelhantemente se mostrará tudo o mais que houver a roda da praça, ficando por este modo cada couza em sua verdadeyra distancia, a qual se conhecerá pello petipê da planta, ou por outro mais miudo, o qual se fará quando as couzas que se houverem de notar forem muyto distantes.

Se a roda do sitio deligniado para se fortificar ouver algu'a bayxa tal que nella se possa occultar o inimigo deve tambem ser notada, e medida a distancia em q' fica para depoys, se ver se será percizo [sic] ganharse, e cobrirse com algu'a obra exterior.

\footnotetext{
${ }^{28}$ Trata-se de amarração de um ponto por triangulação cujo exemplo encontra-se na Estampa $2^{a}$. No desenho as bases de amarração são lados da poligonal de levantamento RZ e ZY.
} 


\section{$\operatorname{Cap}^{\circ}{ }^{8} .^{\circ}$ \\ DO DESENHO DAS FORTIFICAÇÕES DAS PRAÇAS ASSIM REGULARES, COMO IRREGULARES DO POLIGONO EXTERIOR P.A DENTRO.}

As praças regulares são aquellas que são desenhadas sobre alguma figura que tem todos os lados, e angulos iguais, e assim são cercadas de hu'a fortificação uniforme, igual, e de hu'a mesma regra: esta regra se póde executar do lado do poligono exterior para dentro, como tambem tomando para primeyro fundamento o lado do poligono interior, delle para fora se póde armar, e dispor a fortificação: huns se agradão mais de hum modo, outros de outro; ambos são necessarios, hum he mais proprio em alguns cazos, outro em outros: para a fortificação de algu'a villa ou lugar ja cercada ao modo antigo, onde por poupar gastos nos podemos aproveytar dos reparos velhos em todo ou em parte, para delles nos servirmos para cortinas, será mais proprio dispor o desenho do lado do poligono interior para fóra, e o mesmo tambem quando se pertende fortificar algu'a villa ou cidade situada em campanha raza, por não destruir edificios que o Principe ha de pagar; mas para fortificar sitios montuozos (quais ordinariamente se achão) como tambem de lugares cercados de agua, ou proximos a algu'a ribeyra sera melhor fortificar do lado do poligono exterior para dentro, por respeyto de que elegendo primeyro o lugar onde convem que fiquem as pontas dos baluartes, se evita por este modo que entremos com elles na agua, mais do que quizeramos, ou que nos lugares montuozos nos venhão a cahir em sitio tão bayxo, que havendo de ficar senhores da campanha, fiquem dominados de sitios exteriores, e por evitar outras deficuldades que occorrem ordinariamen- 
te na execução dos desenhos, he mais seguro para a fortificação obrar do poligono exterior para dentro, do qual modo trataremos neste $\mathrm{Cap}^{\circ}$, nos seguintes se executará o mesmo do lado interior para fora.

Seja poys a figura o quadro XX para dentro do qual se quer Fig. ${ }^{a} 4 .{ }^{a}$ Est. $3 .{ }^{a}$ fortificar: de huma e outra parte do lado exterior XX se cortem as porções XZ cada hu'a igual aos 5/18 do dito lado exterior: no ponto $\mathrm{Z}$ se levantem perpendiculares de suficiente comprimento, nellas se tomem as porções ZR cada hu'a igual aos 5/72 do mesmo lado exterior; e por diante se continuarão athe $\mathrm{N}$ tanto que as distancias RN seja cada hu'a igual aos 5/48 tambem do dito lado exterior: logo lançando as linhas ou faces XR, e as cortinas NN sera inteyramente fortificado o dito quadrado: nas mais figuras se siguirá o mesmo estillo, mas as partes se tomarão da quantidade que mostrão os numeros na seguinte taboada numero $1 .^{\circ}$ a saber a sobreface que no quadrado ja descripto se tomou de 5/18 do lado exterior sera sempre a mesma em todas as figuras, como mostra a dita taboada; mas a extenção que no quadrado se tomou de 5/72 será no pentagono de 5/54, no exagono de $5 / 44$ et $^{\text {a }}$ assim mesmo o flanco que no quadrado se tomou de $5 / 48$, no pentagono será de $5 / 45$ no exagono de 5/40 et ${ }^{\text {a }}$. do mesmo modo nas mais figuras serão cada hu'a das ditas linhas das partes contheudas na taboada, as quais partes se entendem sempre em todas as figuras serem a respeyto do lado do poligono exterior.

Pello mesmo estillo, e com as partes da mesma taboada se fortificarão as figuras irregulares semelhantemente do lado do poligono exterior p. $^{\text {a }}$ dentro.

São as figuras irregulares aquellas cujos lados e angulos não são todos entre sy iguais: pódem com tudo ser de lados iguais, com 
angulos desiguais; podem tambem ser de angulos iguais com lados desiguais; o que sucede mais vezes he serem assim de lados como de angulos desiguais; sempre com tudo concordão estas figuras com as regulares em que os angulos de hu'as e outras em somma sempre são iguais, a saber os quatro angulos de hu'a figura irregular quadrilatera valem 360 graos, quanto valem tambem os quatro angulos de hum quadrado; os cinco angulos de qualquer pentagono irregular valem 540 graos, quanto valem tambem os cinco angulos em somma de hum pentagono regular, e assim nas mais figuras de mayor numero de lados hindo crescendo em cada hu'a a somma de seus angulos mais 180 graos por cada lado. As figuras regulares devem sempre preceder, e estimarse mais que as irregulares, e ainda

\begin{tabular}{|c|c|c|c|}
\hline $\begin{array}{l}\text { Taboada n. }^{\circ} 1 . \\
\text { com o lado do } \\
\text { regulares, ou ir }\end{array}$ & $\begin{array}{l}\text { rções da } \mathrm{s} \\
\text { exterior } \mathrm{p}\end{array}$ & $\begin{array}{l}\text { ce, extenção do flan } \\
\text { tificar delle p. }{ }^{2} \text { den }\end{array}$ & $\begin{array}{l}\text { mesmo } \\
\text { as as fi }\end{array}$ \\
\hline A saber & Sobreface & Extenção do flanco & Flanco \\
\hline N. ${ }^{\circ} 4$ & $5 / 18$ & $5 / 72$ & $5 / 48$ \\
\hline 5 & $5 / 18$ & $5 / 54$ & $5 / 45$ \\
\hline 6 & $5 / 18$ & $5 / 44$ & $5 / 40$ \\
\hline 7 & $5 / 18$ & $5 / 40$ & $5 / 35$ \\
\hline 8 & $5 / 18$ & $5 / 38$ & $5 / 34$ \\
\hline 9 & $5 / 18$ & $5 / 36$ & $5 / 32$ \\
\hline 10 & $5 / 18$ & $5 / 34$ & $5 / 32$ \\
\hline 11 & $5 / 18$ & $5 / 33$ & $5 / 32$ \\
\hline 12 & $5 / 18$ & $5 / 32$ & $5 / 32$ \\
\hline 18 & $5 / 18$ & $5 / 27$ & $5 / 32$ \\
\hline Linha recta & $5 / 18$ & $5 / 27$ & $5 / 32$ \\
\hline
\end{tabular}

naquellas todos preferem a que tiver mayor numero de lados, a saber preferem o pentagono ao quadrado, o exagono ao pentagono, e assim por diante, sendo em hu'as e outras o mesmo lado; a razão he, porque quantos mais lados tem a figura, tanto melhor commodo oferece para se fortificar com mayores flancos primarios, e secundarios, e tambem mayores angulos flanqueados, como se 
verá quando se envestigarem os comprimentos das linhas e valor dos angulos que resultão em cada hu'a figura das proporções ja propostas na taboada $n .^{\circ} 1^{\circ}$, e alem disto porque as figuras regulares são mais capazes quanto mais se chegão ao circulo, a saber, quanto mayor for o numero de seus lados, sendo huns e outros do mesmo comprimento.

Mas supponhamos que temos hum sitio para fortificar no qual podemos accommodar hum octogono regular, por exemplo de 1200 pés [396m] de lado de poligono exterior, e tambem podemos accommodar hum eneagono de 1100 ou 1030 pés [362m ou $339,9 \mathrm{~m}]$, neste cazo, ou em outro qualquer semelhante, nos devemos antes servir da figura do menor numero de lados, e a razão disto he porque ficão os corpos defendentes (que são os baluartes com mais capacidade) e por tanto mais robustos, e estes sempre se devem preferir aos outros que não tem tanta capacidade.

E porque nem sempre se acha sitio tão dezembaraçado que seja capaz de formar nelle hu'a figura regular, he força eleger aquella irregular que melhor o occupar; suppunhamos foy eleyto o pentagono irregular $\mathrm{ABCFG}$ no qual o lado $\mathrm{AB}$ he de 750 pes

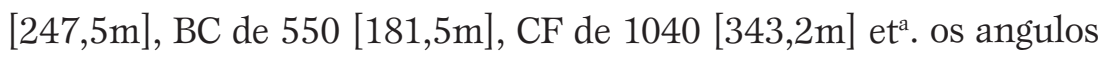
G de 120 graos; o angulo A de 114, B de 116, e os mais como se ve na Fig. 5. ${ }^{a}$ Est. 3. ${ }^{a}$ figura; primeyramente he necessario observar cada cada [sic] hum dos angulos a que figura regular se aproxima mais, porque em cada hum lado de persi se devem seguir as proporções daquella figura regular á qual se aproxima mais o menor angulo proximo do dito lado, e por tanto poys que o angulo $\mathrm{F}$ o qual he de 90 graos e 30 minutos se ajusta mais com o angulo do quadrado do que de nenhuma outra figura se deve na fortificação do lado FG seguir a proporção do quadrado, posto que o angulo G seja de 120 graos, 
e por tanto justamente de exagono, e tambem posto que a figura toda proposta para fortificar seja pentagono; por tanto no dito lado se tomarão as sobrefaces FZ, GZ cada hu'a de 5/18 do dito lado, a saber cada hu'a de 180 pês e $5 / 9$ de pê [59,58m]: dos pontos $Z$ se levantarão as duas perpendiculares ZY, nas quais se tomarão as porções ZO cada hu'a de 45 pês, e $5 / 36$ de pê $[14,89 \mathrm{~m}]$, que são os $5 / 72$ do mesmo lado exterior FG o qual he de 650 pês [214,5m]: as ditas perpendiculares $\mathrm{ZO}$ se continuarão de $\mathrm{O}$ athe $\mathrm{Y}$ mais 67 pês e 17/24 de pê [22,34m], que são os 5/48 de 650 lado exterior, e lançando as faces $\mathrm{FO}, \mathrm{GO}$, e a cortina YY ficará fortificado o dito lado $\mathrm{GF}^{29}$.

Com a mesma proporção do quadrado se fortificará tambem o lado FC por respeyto do mesmo angulo $\mathrm{F}$ ser proximo ao angulo do quadrado.

Mas o lado $\mathrm{CB}$ se fortificará como pentagono poys que o menor angulo $\mathrm{C}$ he ja mais proximo ao angulo desta figura regular; a saber, se tomará cada hu'a das sobrefaces CX, BX de 152 e 7/9 [50,41m], que são os 5/18 de 550 [181,5m] comprimento do dito lado; a extenção do flanco XR de 51 [16,83m], ou na verdade de 50 25/27 [16,8m] que são os 5/54 do mesmo lado CB; o flanco RG de 61 e $1 / 9$ [20,17m] a saber de $5 / 45$ ou 1/9 do dito lado exterior $\mathrm{CB}$; lançando então as faces $\mathrm{CR}, \mathrm{BR}$, e a cortina GG ficará fortificado aquele lado.

Cada hum dos lados GA, BA se fortificará com as proporções do exagono por ser ja o angulo A igual ao valor medio entre o angulo do pentagono, e o do exagono, porque neste cazo (posto

\footnotetext{
${ }^{29}$ A Figura 5 da Est. 3 encontra-se incompleta, pois não mostra os pontos $\mathbf{Z}, \mathbf{Y}$ e $\mathbf{O}$ desta demonstração. Devemos supor, por analogia com a Fig. 4, que o ponto $\mathbf{Z}$ encontra-se nos segmentos FG e GA de onde nascem as perpendiculares que vão formar flancos dos baluartes. Pela descrição do texto e os valores declarados deve-se concluir que YY são os limites da cortina e o ponto $\mathbf{O}$ a junção da face com o flanco.
} 
que era livre o uzar das proporções de qualquer das ditas duas figuras) como a proporção da mayor, a saber do exagono nos consede mayores flancos, sem ofença do angulo flanqueado, he melhor fortificar pelas suas proporções; o mesmo se guardará todas as vezes que suceder hum angulo medio entre outras quaisquer duas figuras, como por exemplo se se achar hum angulo de 124 graos e $\underline{17}$ minutos, que he o meyo entre o angulo do exagono, e eptagono regulares, ordenaremos antes a fortificação com as proporções desta figura mayor, que daquella menor.

Pello mesmo estilo se poderá fortificar qualquer outra figura irregular, se bem ficarão melhor ordenadas aquellas figuras cujos lados forem entre si menos desiguais, e tambem cujos angulos mais se aproximarem huns aos outros, que val[e] o mesmo quer dizer, serão melhores aquellas figuras que forem menos irregulares, ou mais proximas a regularidade, pelo que ao menos se trabalhará que cada dous lados proximos entre si não sejão tão deziguais, que o menor seja menos que subtriplo do mayor, a saber que tendo hum lado 900 pés [297m] junto delle não ficará outro menor de 300 [99m].

Para mayor perfeyção tambem se advertirá que hum angulo não exceda a outro proximo a elle com grandissimo excesso, a saber que proximo a hum angulo de quadrado que he de 90 graos não fique outro mayor que o da figura dobrada do quadrado que he o octogono, cujo angulo he de 135 graos; o angulo do pentagono se não admita ficar proximo com outro mayor que athe o da figura de 10 lados que he de 144 graos.

Ao angulo do exagono se póde bem accommodar o de qualquer outra figura mayor athe 12 lados.

Nas mais figuras se terá a mesma regra, a saber o angulo de qualquer figura menor se poderá accommodar o de outra figura 
tanto mayor quanto for o duplo do numero dos lados da menor: mas em cazo de necessidade não podendo as couzas sahir tanto accommodadas como se dezeja, se poderá tolerar q' com hum angulo de hu'a figura menor avezinhe outro de figura tanto mayor quanto for o triplo da menor, a saber, com o angulo do quadrado se poderá tolerar que avezinhe o angulo do duo decagono que he tripo [triplo] do quadrado: com o angulo do pentagono se póde tolerar que avezinhe o angulo da figura de 15 lados; e assim nas mais, mas isto se entende quando não possa ser de outra maneyra.

Não podendo finalmente accommodarse a figura irregular com a sobredita perfeyção na vezinhança de seus angulos e lados, será mais conveniente fazer algu'a mudança acrescentando em hum, ou diminuindo em outro, como se exemplifica no Methodo Luzitanico ${ }^{30}$ no scholio $1^{\circ}$ do Cap. ${ }^{\circ} 15$ p. $^{\text {te }} 1^{\text {a }}$ ou tambem mudando a figura em outra, (e isto será melhor) como se ve executado na figura 6 que he a planta da fortificação da praça de Alfayates na provincia da Beyra, na qual se emmendou a fortificação antiga signalada pela linha de pontinhos com o novo exagono irregular signalado de risco seguido.

Athe aqui he o mesmo modo de obrar que ensina o Methodo Estampa $4^{a}$ Lusitanico no $\operatorname{Cap}^{\circ} 14$ da $1^{\text {a }}$ p. $^{\text {te }}$ secção $1^{\text {a }}$ com as mesmas circunstancias, e cautellas explicadas largamente no proximo Cap. ${ }^{\circ}$ as quais eu não quis deyxar, nem variar o modo de proceder por não diminuir couza algu'a na perfeyção e facilidade do dito methodo; so variey as proporções com a mesma liberdade que o autor do dito methodo teve para nelle propor tres diferentes, para desenhar todos tres do lado do poligono exterior para dentro, e todavia se podem achar ainda muytas mais.

\footnotetext{
${ }^{30}$ Esta referência ao Methodo Luzitanico de Serrão fica na p. 56 da edição de 1680.
} 
Quem the não agradarem os que proponho, póde continuar, e obrar por qualquer das ditas tres propostas no dito Methodo Luzitanico; com declaração porem que supposto o autor diga que se agrada mais das proporções que propoz em segundo lugar no Cap $^{\circ} 45$, eu aconselhara se preferissem as do Cap ${ }^{\circ} 47$ ás do Cap ${ }^{\circ}$ 45; e estas ás do $\mathrm{Cap}^{\circ}$ 14; a razão he pella mayoria dos flancos, e praça do baluarte que rezulta mayor das ditas proporções do Cap ${ }^{\circ}$ 47 que de nenhu'as das outras como se póde ver em qualquer figura fortificada por humas e outras proporções.

$\mathrm{Cap}^{\circ}$ 9. $^{\circ}$

DO DESENHO DO LADO DO POLIGONO

INTERIOR PARA FORA NAS PRAÇAS REGULARES.

Para o desenho do poligono exterior para dentro forão as principays linhas a sobreface, a extenção do flanco, e o mesmo flanco: mas agora do poligono interior para fora servirão a dimigola, o flanco primario, e o secundario, ou complemento da cortina, pella maneyra seguinte.[:]

Dado qualquer poligono regular por exemplo o quadrado AA para delle se dispor para fora a fortificação; de cada hum dos lados AA se cortem as demigolas AG cada hu'a igual de 15/94 do dito lado; Fig. ${ }^{a} 7^{a}$ Est. $5^{a}$ nos pontos G se levantem os flancos perpendiculares GZ cada hum de outro tanto como a demigola: da cortina GG que ja fica determinada entre os dous flancos se tome 1/16 para flanco secundario GR; ou se podião tomar os 15/16 da mesma cortina para cada hum dos seus complementos, que sam aquellas partes da cortina que ficão debayxo das razantes athe os angulos flanqueantes; isto assim feyto lansem-se 
as linhas razantes RZX as quais concorrendo nos pontos $\mathrm{X}$ determinarão as faces dos baluartes.

Do mesmo modo se fortificará outra qualquer figura de mayor numero de lados, tomando porem as partes na seguinte taboada a saber a demigola que no quadrado se tomou de 15/94 do lado interior, será no pentagono de 7/38; no exagono de 6/31, no eptagono de $1 / 5$ et. $^{a}$ o flanco que no quadrado se tomou igual á demigola a saber de 15/94 do lado interior será no pentagono 3/19 no exagono 6/35 et. ${ }^{a}$ da mesma sorte o flanco secundario que no quadrado se tomou $1 / 16$ da

\begin{tabular}{|c|c|c|c|c|}
\hline A saber & Demigola & Flanco $1 .^{\circ}$ & Flanco $2 .^{\circ}$ & $\begin{array}{c}\text { Complemento } \\
\text { da cortina }\end{array}$ \\
\hline $\mathrm{N}^{0} 4^{\circ}$ & $15 / 94$ & $15 / 94$ & $1 / 16$ & $15 / 16$ \\
\hline 5 & $7 / 38$ & $3 / 19$ & $1 / 4$ & $3 / 4$ \\
\hline 6 & $6 / 31$ & $6 / 35$ & $5 / 16$ & $11 / 16$ \\
\hline 7 & $1 / 5$ & $5 / 26$ & $55 / 192$ & 137/192 \\
\hline 8 & $4 / 19$ & $5 / 26$ & $29 / 96$ & $67 / 96$ \\
\hline 9 & $23 / 106$ & $11 / 55$ & $19 / 64$ & $45 / 64$ \\
\hline 10 & $2 / 9$ & $15 / 77$ & $1 / 3$ & $2 / 3$ \\
\hline 11 & $23 / 101$ & $5 / 26$ & $17 / 48$ & $31 / 48$ \\
\hline 12 & $23 / 99$ & $7 / 37$ & $3 / 8$ & $5 / 8$ \\
\hline 13 & $5 / 21$ & $5 / 27$ & $3 / 8$ & $5 / 8$ \\
\hline 14 & $7 / 29$ & $17 / 93$ & $3 / 8$ & $5 / 8$ \\
\hline 15 & $15 / 62$ & $9 / 50$ & $3 / 8$ & $5 / 8$ \\
\hline 16 & $21 / 85$ & $5 / 28$ & $3 / 8$ & $5 / 8$ \\
\hline 17 & $27 / 109$ & $12 / 67$ & $3 / 8$ & $5 / 8$ \\
\hline 18 & 47/190 & $27 / 132$ & $91 / 192$ & $101 / 192$ \\
\hline 20 & $1 / 4$ & $9 / 51$ & $91 / 192$ & $101 / 192$ \\
\hline 24 & $25 / 98$ & $5 / 29$ & $91 / 192$ & $101 / 192$ \\
\hline 36 & $5 / 19$ & $1 / 6$ & $91 / 192$ & $101 / 192$ \\
\hline 72 & $3 / 11$ & $5 / 31$ & $91 / 192$ & $101 / 192$ \\
\hline Linha recta & $5 / 18$ & $3 / 32$ & $91 / 192$ & $101 / 192$ \\
\hline
\end{tabular}

cortina livre, será no pentagono $1 / 4$, no exagono 5/6, e quem quizesse tomar o complemento da cortina, tomando este no quadrado de 15/16 tomaria no pentagono $3 / 4$, no exagono 11/16 como 
se ve na taboada, cujas proporções concordão tam proximamente com as do $\mathrm{Cap}^{\circ}$ antecedente, que fortificando qualquer figura do lado do poligono exterior para dentro, se outra vez a mesma figura se fortificar do lado que lhe rezulta interior para fora se ajustará hu'a e outra fortificação com muy pouca differença, ou sem nenhu'a: o mesmo sucederá se fortificada qualquer figura do lado do poligono interior para fora, outra vez se fortificar para dentro do lado exterior que lhe rezulta, porque se ajustará da mesma sorte hu'a e outra fortificação; que supposto esta circunstancia seja de pouquissimo ou nenhum momento, póde com tudo alguem agradar-se de ver ajustar hu'a e outra fortificação; e a quem the parecer que se podem algumas figuras fortificar com mayores flancos (em que se não engana) deyxada a dita taboada póde usar em seu lugar das proporções que se seguem ordenadas pelo mesmo estillo de combinar a demigola e flanco com o lado do poligono interior em qualquer figura, e o flanco secundario, ou o complemento da cortina a respeyto da mesma cortina, como se ve na seguinte taboada.[:]

\begin{tabular}{|c|c|c|c|c|}
\hline \multicolumn{5}{|c|}{$\begin{array}{l}\text { Taboada } \mathrm{n} .^{\circ} 3 .^{\circ} \mathrm{p}^{\mathrm{a}} \text { fortificar do lado do poligono interior } \mathrm{p} .{ }^{\text {a }} \text { fora todas as figuras } \\
\text { regulares, ou irregulares. }\end{array}$} \\
\hline A saber & Demigola & Flanco $1 .^{\circ}$ & Flanco $2 .^{\circ}$ & $\begin{array}{l}\text { Complemento } \\
\text { da cortina }\end{array}$ \\
\hline $\mathrm{N}^{\circ} 4$ & $4 / 25$ & $4 / 25$ & $1 / 16$ & $15 / 16$ \\
\hline 5 & $7 / 40$ & $1 / 6$ & $1 / 5$ & $4 / 5$ \\
\hline 6 & $1 / 5$ & $19 / 100$ & $1 / 4$ & $3 / 4$ \\
\hline 7 & $23 / 120$ & $11 / 60$ & $12 / 37$ & $25 / 37$ \\
\hline 8 & $1 / 5$ & $23 / 120$ & $25 / 72$ & $47 / 72$ \\
\hline 9 & $5 / 24$ & $1 / 5$ & $23 / 70$ & $47 / 70$ \\
\hline 10 & $5 / 24$ & $1 / 5$ & $12 / 35$ & $23 / 35$ \\
\hline 11 & $5 / 24$ & $1 / 5$ & $5 / 14$ & $9 / 14$ \\
\hline 12 & $5 / 24$ & $1 / 5$ & $13 / 35$ & $22 / 35$ \\
\hline 18 & $2 / 9$ & $1 / 5$ & $2 / 5$ & $3 / 5$ \\
\hline 36 & $9 / 40$ & $5 / 24$ & $16 / 33$ & $17 / 33$ \\
\hline Linha recta & $9 / 40$ & $5 / 24$ & $16 / 33$ & $17 / 33$ \\
\hline
\end{tabular}


Póde tambem quem quizer usar das proporções explicadas no Methodo Luzitanico, as quais repito aqui para cada hum escolher as que mais lhe contentarem, e são as ditas proporções as da seguinte taboada.[:]

\begin{tabular}{|c|c|c|c|c|}
\hline \multicolumn{5}{|c|}{$\begin{array}{l}\text { Taboada n. }{ }^{0} 4 \text { das proporções do Methodo Luzitanico Cap. }{ }^{0} 1^{0} \text { secção } 2^{\text {a }} \text {, para } \\
\text { desenhar do lado do poligono interior p. }{ }^{a} \text { fora todas as praças de baluartes inteyros. }\end{array}$} \\
\hline \multicolumn{5}{|c|}{\begin{tabular}{|c|c|c|c|c} 
Figuras & Demigolas & Flanco 1. & Flanco 2. & $\begin{array}{c}\text { Complemento } \\
\text { da cortina }\end{array}$ \\
\end{tabular}} \\
\hline \multicolumn{5}{|c|}{\begin{tabular}{c|c|c|c|c} 
& & & & da cortina \\
4 & $1 / 6$ & $3 / 20$ & $1 / 20$ & $19 / 20$
\end{tabular}} \\
\hline \multicolumn{5}{|c|}{\begin{tabular}{c|c|c|c|c}
5 & $11 / 60$ & $1 / 6$ & $1 / 5$ & $4 / 5$ \\
\end{tabular}} \\
\hline 6 & $4 / 5$ & $1 / 6$ & $1 / 4$ & $3 / 4$ \\
\hline \multicolumn{5}{|l|}{7} \\
\hline 8 & $1 / 5$ & $1 / 6$ & $5 / 12$ & $7 / 12$ \\
\hline \multicolumn{5}{|l|}{9} \\
\hline \multicolumn{5}{|l|}{10 athe 14} \\
\hline \multicolumn{5}{|l|}{15 athe 19} \\
\hline \multicolumn{5}{|l|}{20 athe 24} \\
\hline 25 athe 29 & $5 / 24$ & $1 / 5$ & $1 / 2$ & $1 / 2$ \\
\hline 30 athe 59 & $13 / 60$ & $1 / 5$ & $1 / 2$ & $1 / 2$ \\
\hline $\begin{array}{l}60 \text { athe linha } \\
\text { recta }\end{array}$ & $14 / 60$ & $1 / 5$ & $1 / 2$ & $1 / 2$ \\
\hline
\end{tabular}

Podiase tambem combinar o flanco segundo, e o complemento da cortina a respeyto do lado interior; porem como no irregular nos queremos servir das mesmas taboadas, e nestas figuras ordinariamente serão desiguais as duas demigolas sobre hum mesmo lado, he mais accommodado tomar o dito flanco segundo[?] antes a respeyto da cortina livre, que do lado interior pella maneyra que se declara no Cap. ${ }^{\circ}$ seguinte: 


\section{$\operatorname{Cap}^{\circ} 10 .^{\circ}$ \\ DO MESMO DESENHO DO POLIGONO \\ INTERIOR P. ${ }^{A}$ FÓRA NAS PRAÇAS IRREGULARES.}

Para a fortificação do lado do poligono interior para fora nas figuras irregulares não póde servir hu'a so regra com a qual se formem logo os baluartes, de modo que por cada lado fiquem conrespondendo com iguais faces, e iguais flancos primarios, e secundarios, como sucedeu do lado exterior para dentro; mas valendo-nos de ambos os modos das figuras regulares explicadas nos Cap. ${ }^{\text {os }}$ antecedentes poderemos conseguir este intento pello seguinte methodo.[:]

Dado qualquer poligono irregular que seja por exemplo o Fig. ${ }^{a} 8$ Est. [5] exagono ABCFGH; primeyramente escolheremos aquelles lados aquelles lados [repetido, sic] nos quais seja mais percizo [sic] valermonos para cortinas das mesmas linhas ou muralhas velhas que formão a figura, e sejão estas os tres lados $\mathrm{AB}, \mathrm{CF}, \mathrm{GH}$ os quais se fortificarão para fora pellas proporções do Cap. ${ }^{\circ}$ antecedente guardando em cada hum a proporção daquella figura regular a que for mais proximo o menor angulo colateral a cada hum dos ditos lados; a saber, porque o lado $\mathrm{AB}$ está entre dous angulos hum de 119 graos e 30 minutos, que he quazi de exagono, outro de 95 graos e 30 minutos, que he mais proximo do quadrado, se deve fortificar o dito lado pellas proporções do quadrado, que he figura menor; e assim no dito lado AB se tomarão os seus 15/94 para as demigolas AM, BM: outro tanto para os flancos perpendiculares MN; os secundarios MR se tomarão de 1/16 da cortina MM; para determinar as faces será necessario partir primeyro pello meyo $\mathrm{o}$ angulo menor A como se ensinou na propozição $9^{\mathrm{a}}$ do livro $1 .^{\circ}$ 
de Euclides, com hu'a linha indifinita AQ, então lançando do ponto $\mathrm{R}$ a linha $\mathrm{RNQ}$ ficará determinada a face $\mathrm{NQ}$, com a qual se igualará a outra NS.

Quem quizer póde ter calculado primeyro a grandeza da capital $^{31}$ em cada hu'a figura regular, ou a respeyto do lado interior, ou da demigola, ou da cortina, e escuzará valerse do segundo flanco MR, mas logo determinada a capital AQ, e o flanco NM, de hum a outro ponto lansará a linha QN, a qual será a face.

No lado CF se seguirão as proporções do pentagono por ser o menor angulo $\mathrm{F}$ mais proximo ao desta figura, por tanto será cada huma da demigolas CG, GF, os 7/38, os flancos GI de 3/19 do dito lado CF; os flancos secundarios GZ de 1/4 da cortina GG: lançando depoys a razante ZIV athe que se encontre com a capital $\mathrm{FV}$, a qual partirá o angulo $\mathrm{F}$ pello meyo, ficará determinada a face IV, á qual se igualará a outra IS, e ficará fortificado aquelle lado.

Do mesmo modo se fortificará o lado $\mathrm{HG}$, mas com as proporções do exagono, por ser o menor angulo G de 120 graos, pello que se tomarão as demigolas GX, HX de 6/31: os flancos XO de 6/35 do dito lado HG: os flancos secundarios XK de 5/16 da cortina XX, e partindo o angulo G pello meyo com a capital GV, se tirará a razante KOV, a qual determinará a face OV com a qual se igualará a outra OQ.

Fortificados os ditos tres lados se imaginem as linhas exteriores SS, VV, QQ para dentro das quais se fortificará pello mesmo estillo do Cap $^{\circ} 8^{\circ}$ a saber na linha ou lado exterior SS se tomarão as sobrefaces SH de 5/18, a extenção HP de 5/44; os flancos PY

\footnotetext{
${ }^{31}$ Está se referindo a Linha Capital, que liga a ponta (que forma o ângulo flanqueado) de um baluarte ao ângulo do polígono interno de defesa, onde se insere o dito baluarte. Segundo Azevedo Fortes: he aquella linha, que se lança do ângulo do polígono exterior ao ângulo do polígono exterior [interior - engano que passou na revisão ortográfica da edição consultada de 1728].
} 
de 5/40 do dito lado exterior SS; as quais proporções são pertencentes ao exagono por ser mais proximo a esta figura o menor angulo B, o qual he de 119 graos e 30 minutos.

O lado VV se fortificará como pentagono, por ser o menor angulo $\mathrm{F}$ de 103 graos mais proximo ao desta figura.

O lado exterior QQ se fortificará com as proporções do quadrado, porque o angulo A de 95 graos e 30 minutos he mais proximo desta figura, e assim ficará inteyramente fortificado o exagono irregular $\mathrm{ABCFGH}$, com iguais faces, e iguais flancos primarios e secundarios por cada lado da fortificação.

Podiaose fortificar pellas proporções do poligono interior os lados $\mathrm{BC}, \mathrm{FG}, \mathrm{AH}$, e os outros tres serem fortificados para dentro das linhas exteriores imaginadas depoys da fortificação dos sobreditos tres lados BC, FG, AH, como se ve executado na mesma figura 8 repetida com o numero 9 estampa 6 .

Se a figura for de numero impar se não poderão fortificar Fig. ${ }^{a} 10$ Est. $6^{a}$ para fora mais que a metade menor do numero de seus lados, como por exemplo no pentagono irregular $\mathrm{ABCFG}$ se podem eleger os lados $\mathrm{AB}, \mathrm{FG}$, os quais se devem fortificar para fora, o primeyro $\mathrm{AB}$ pellas proporções do pentagono por ser o angulo A de 113 graos; o segundo FG como quadrado por ser o menor angulo $\mathrm{F}$ proximo desta figura.

Fortificados os ditos lados se imaginará a linha $\mathrm{KZ}$ e as linhas RX, YX parallelas aos lados BC, CF, as quais tres linhas $\mathrm{KZ}$, $\mathrm{RX}, \mathrm{YX}$ se fortificarão como lados de poligono exterior pellas proporções e modo do Cap. ${ }^{\circ} 8 .^{\circ}$ como se ve executado na mesma figura 10. Podiase variar a eleyção dos primeyros dous lados que se hão de fortificar para fora tantas vezes quantas se ve executado nas figuras 11, 12, 13 e 14 Est. 7 e 8. 
Assim mesmo em outra qualquer figura de numero impar se poderá variar a eleyção dos lados que se hão de fortificar do poligono interior para fora tantas vezes quantos forem os lados da figura; sendo sempre os ditos lados tomados alternativamente, como se tomarão nas ditas figuras de numero 10 athe numero 14 , sendo que nas figuras de numero par so se poderá variar esta eleyção duas vezes, como se vio nas figuras numero 8 e 9 que he hu'a mesma so os baluartes diferentes.

Pelo que sendonos proposto qualquer poligono interior para fortificar não será ouciozo [sic] formar primeyro no papel os baluartes com toda aquella variedade que a figura póde admitir, para então escolher aquelles que parecer se accommodão melhor no terreno; conhecendose tambem logo quanto com elles se alarga, ou quanto se estreyta a figura, e tambem quais baluartes ficão entre si mais bem proporcionados.

Mas porque póde a alguem parecer este modo de fortificar muyto contingente, e como por acazo; ou póde ser necessario fortificar para fora todos os lados da figura, de sorte que sempre the fiquem servindo todos os ditos lados de cortinas, não fazendo cazo da conrespondencia das faces e flancos de cada hum de dous baluartes proximos, poys que esta conrespondencia não he de necessidade da fortificação, assim como não he de necessidade a igualdade nem das faces, nem dos flancos em hum mesmo baluarte, porque estes em hu'a fortificação irregular podem ser desemelhantes, e desiguais, com tanto que cada hum em si tenha suficiente valentia: neste cazo deyxando o methodo ensinado neste Cap. ${ }^{\circ}$ se uzará do seguinte modo pello qual se fortificarão as mesmas figuras irregulares de sorte que rezultem logo determinados os baluartes sem dependencia de mais eleyção que a primeyra da figura que se ha de fortificar. 
Cap. $^{\circ} 11 .^{\circ}$

DE OUTRO MODO DE DESENHAR AS FIGURAS IRREGULARES DO POLIGONO INTERIOR P. ${ }^{\mathrm{A}}$ FORA.

Não se estimando a conrespondencia dos baluartes, mas so sim que sejão em si robustos, e valentes, tambem não uzaremos de accomodar o mayor angulo da figura ao menor na forma que se disse no Cap. ${ }^{\circ}$ antecedente, mas cada hum angulo do poligono irregular se fortificará de persi com as proporções daquella figura a que mais se aproximar buscando primeyro as demigolas de todos os angulos para que determinadas as cortinas se possa tomar o flanco secundario a respeyto de cada hum dos angulos, ou baluartes que sobre elles assentão; por exemplo se torna a fortificar o mesmo exagono irregular das difiguras [sic] 8 e 9 agora com o numero 15, no qual o angulo A de 95 graos e 30 minutos se deve Est.9. ${ }^{a}$ [Fig.15] fortificar como quadrado por ser mais proximo ao desta figura.

Tomem-se por tanto a duas demigolas AY de 15/94 do lado $\mathrm{AB}$, e AX de outro tanto do lado AH. Levantem-se os flancos perpendiculares $\mathrm{YN}$ igual com $\mathrm{AY}$, e $\mathrm{XN}$ igual com AX.

$\mathrm{O}$ angulo $\mathrm{B}$ se ha de fortificar como exagono por ser de 119 graos e 30 minutos proximo ao desta figura; por tanto a demigola $\mathrm{BM}$ será 6/31 do lado $\mathrm{AB}$ : o flanco $\mathrm{MN}$ de 6/35 do mesmo lado AB: a demigola BL será de 6/31 do lado BC; o flanco LN será de 6/ 35 do lado BC.

$\mathrm{O}$ angulo $\mathrm{C}$ que he de 131 graos se fortificará com as proporções do octogono, e assim será cada hu'a das demigolas 4/19 a saber CR 4/19 do lado CB, e CP 4/19 do lado CF: os flancos será cada hum de 5/26 $\mathrm{RN}$ a respeyto do lado $\mathrm{CB}$, e $\mathrm{PN}$ a respeyto do lado CF. 
$\mathrm{O}$ angulo $\mathrm{F}$ de 103 graos se fortificará como pentagono por ser mais proximo ao desta figura, e assim serão as suas demigolas de $7 / 38$, os flancos de $3 / 19$, a saber, a demigola $\mathrm{FQ}$ de $7 / 38$ e o flanco QN de 3/19 tudo do lado FC: a demigola FS será de 7/38, e o flanco SN de 3/19, huma e outra couza do lado FG.

$\mathrm{O}$ angulo $\mathrm{G}$, o qual he justamente de exagono, se fortificará com as proporções desta figura, e assim será a demigola GV de 6/ 31 do lado GF; o flanco VN será de 6/35 do mesmo lado: a demigola GF será de 6/31 e o flanco FN de 6/35 do lado GH.

$\mathrm{O}$ angulo $\mathrm{H}$ de 151 graos se fortificará com as proporções do duodecagono por ser proximo ao desta figura e por tanto será a demigola HZ de 23/99 do lado HG; o flanco ZN será de 7/37 do mesmo lado: a demigola HI será de 23/99 do lado AH; o flanco IN de 7/37 do mesmo lado AH.

Determinadas assim as demigolas e flancos primarios, para asignar os secundarios nas cortinas, outra vez se deve haver respeyto ao valor de cada angulo, e assim o flanco secundario YO será de 1/6 da cotina YM; outro tanto será o flanco secundario XO da cortina XI, por ser o angulo A fortificado pellas proporções do quadrado.

O flanco MO será 5/16 da cortina YM; outro tanto será o flanco LO da cortina LR por ser o angulo B fortificado pellas proporções do exagono: o flanco RO será 29/96 da cortina RL, e outro tanto o flanco PO da cortina PQ por ser o angulo $\mathrm{C}$ fortificado pellas proporções do octogono: o flanco QO será 1/4 da cortina $\mathrm{QP}$, e outro tanto será o flanco SO da cortina SV, por ser o angulo $\mathrm{F}$ fortificado pellas proporções do pentagono.

O flanco VO será de 3/16 da cortina VS, e outro tanto será o flanco TO da cortina TZ por ser de exagono o angulo $\mathrm{G}$. 
Os flancos ZO, e IO será cada hum de $3 / 8$ o primeyro $3 / 8$ da cortina ZT, o segundo $3 / 8$ da cortina IX, porque o angulo $\mathrm{H}$ foy fortificado como angulo da figura de doze lados.

Determinados assim os flancos se lançarão as razantes que se encontrarão nos pontos $\mathrm{K}$ e ficarão feytos os baluartes, como mostra a fig. ${ }^{a} 15$.

Qualquer outro poligono irregular se fortificará pello mesmo estillo, e com as proporções de qualquer das tres taboadas numero $2 .^{\circ} 3 .^{\circ}$ e $4 .^{\circ}$.

He porem necessario repetir a advertencia que se fes no fim do Cap. ${ }^{\circ} 8 .^{\circ}$ a saber que junto de hum lado grande não fique outro muyto pequeno; o mesmo he a cerca dos angulos: no dito Cap. ${ }^{\circ} 8$ se admitio a vezinhança entre dous lados hum triplo do outro; aqui he necessario mais rigor, porque ja será $\mathrm{m}^{\text {to }}$ se o lado mayor for mais do duplo do menor; pello que se deve estudar muyto em igualalos quanto possa ser, poys quanto menos differença entre si tiverem, mais compostos sahirão os baluartes: o mesmo he a respeyto dos angulos, ainda que não com tanta necessidade: e de qualquer modo que se execute a fortificação irregular será bom que toda a planta antes da execução se confira com os axiomas gerais do Cap. ${ }^{\circ} 7 .^{\circ}$ para melhor satisfação, e cada huma de suas linhas em particular com a doutrina dos capitulos seguintes acerca de cada huma dellas. 


\section{Cap. $^{\circ} 12 .^{\circ}$ \\ DA LINHA FECHANTE E ALCANCE \\ DO TIRO DE MOSQUETE.}

O fim universal da fortificação (como ja se disse no Cap. $^{\circ}$ $\left.1 .^{\circ}\right)$ he o defenderse do inimigo com ventagem; mas o fim ou razão da forma que hoje tem as fortificações modernas he porque todas suas partes sejão flanqueadas, isto he, que não haja parte alguma, ou lugar a roda da praça que não seja visto lateralmente; ${ }^{32}$ por ser visto se entende ser defendido, e por ser defendido se entende com as armas que servem para defender, ou offender de longe (que nesta materia são inseparaveys a defença e offença) as quais são o mosquete (hoje armas chamadas granadeyras) e o canhão: daqui vem hu'a duvida a qual he a que distancia se deve por a parte defendida, daquella que a defende, se a distancia de tiro de mosquete, se de canhão: alguns tiverão para si que se devia por a tiro de canhão, por ser esta a mais violenta e eficaz arma com a qual se offende o inimigo mais ao longe, e sofrerem por esta cauza os baluartes mayor distancia entre si com o que se podem fazer mayores, e com mayores flancos, assim rectos como oblicos, e a praça cercarse com menos baluartes, de que se segue menos custo, multiplicandose este no mayor numero delles se a defensa se tomar do alcance do mosquete: alem de que sendo assim ficarião os expugnadores com ventagem aos sitiados pello mayor numero de tiros com que os podem offender.

Mas esta opinião he hoje reprovada pellos modernos, os quais todos uniformemente julgão que a linha da defença se não deve fazer mais comprida do que o tiro do mosquete, porque da razão,

\footnotetext{
${ }^{32}$ Outra vez a preocupação com a doutrina do flanqueamento.
} 
e da experiencia consta que com os mosquetes se defendem melhor as praças, do que so com a artelheria, porque o uzo desta he custozo, deficil tardo, e incerto.

Pello contrario o uzo dos mosquetes he muyto menos custozo, facil, prompto, e mais certo: os mosqueteyros estão em hu'a continua e repetida carga, porque disparando huns, sucedem, outros, como tambem outros vivos em lugar dos mortos; se o inimigo arroina os flancos com qualquer reparo se cobrem, e quem negará que com mil tiros menores se rebate melhor o inimigo do que com hu'a so balla mayor: nem obstão as razões contrarias, porque se responde em quanto á primeyra que a artelheria he a mais violenta e eficaz arma com a qual se offende mais ao longe; isto não prova outra couza mais que ser a artelheria util e necessaria nas praças fortificadas, o que confessamos, poys com ella se offendem e desfazem as batarias que o inimigo levanta para bater as muralhas; se desfazem os travezes $^{33}$ e galarias com que intenta a passagem do fosso: mas a questão he se basta se a artelheria ao menos dos flancos, ou se melhor se defendem as praças podendo se valer juntamente da força do mosquete, que he o que dicemos.

Em quanto á segunda de que se podem os baluartes fazer mayores, e com menos numero delles cercarse a praça, em que se dispende menos, respondo que esta razão valeria quando a defença se não melhoráse, mas melhorase muyto fazendo a fexante a tiro de mosquete, poys alem da defença desta arma se podem os defensores valer da artelheria ainda com mayor effeyto atirando de mais perto.

\footnotetext{
${ }^{33}$ Travezes são pequenos obstáculos transversais que se constroem nas estradas cobertas, para evitar o tiro enfiado dos inimigos se por ventura tomarem uma parte desta estrada.
} 
A ultima razão que os expugnadores ficarião com ventagem pello mayor numero de armas com que podem offender, se responde, que se das defenças serem curtas rezulta mayor offença contra os defensores, tambem rezulta mayor contra os expugnadores, com que em hum e outro cazo ficão iguais; porque assim como dizem que sendo a linha fexante a tiro de artelheria os defensores dos flancos se podem ser offendidos daquelles canhões que se podem acommodar defronte do angulo flanqueado opposto tambem se the póde dizer que sendo a fechante a tiro de mosquete só poderam ser offendidos daquelles mosqueteyros que se podem accommodar no mesmo espaço.

Pello que a linha fechante deve ser determinada pello alcance do mosquete, o qual podemos determinar athe 800 pês $[264 \mathrm{~m}]^{34}$, e ainda athe $850[280,5 \mathrm{~m}]$ pello mayor termo, que posto alcance mais, não se deve estender a fechante a todo o mayor termo, para que a defença fique dentro do tiro vehemente, e athe esta distancia de 850 pês $[280,5 \mathrm{~m}]$ sucederá assim, podendo ja haver larga capacidade na praça dos baluartes, bons flancos primarios, e boas demigolas, conforme tudo aos requezitos da boa fortificação.

Nem obsta a oppozição de que os mais dos AA [autores] modernos fazem a dita fechante mais curta e assim são feytas as melhores praças de Holanda, pello que nos não devemos estender a mais de 720 pês $[237,6 \mathrm{~m}]$, ou athe $750[247,5 \mathrm{~m}]$, a que se responde que esta materia pende [depende] mais da experiencia, que da razão ou authoridade, e quem fizer a experiencia achará que os

\footnotetext{
${ }^{34} \mathrm{O}$ alcance útil máximo de um mosquete da época, segundo experto da maior credibilidade, o Marechal Vauban (Regra XV), era de 120 a 125 toesas [233,8m a 243,6m], discordando de Goldman, famoso tratadista holandês, que aceitava um alcance de 150 toesas [292,3m]. Assim, a opinião de Vellozo situa-se em posição intermediária à opinião de Vauban e de Goldman. Há que se considerar na nossa avaliação que Vauban viveu e atuou, basicamente no Século XVII (morreu em 1707) e na época que Vellozo escreveu o seu tratado os mosquetes já deveriam ser mais eficientes em alcance e precisão de tiro.
} 
mosquetes atirão bem alem da dita distancia de 850 pês [280,5m]; e se as praças de Holanda são feytas a menor distancia, não se segue dahi que se não possão fazer outra mayores sem erro, como são feytas muytas praças de Italia que são reputadas por muyto boas, e excedem as de Holanda na valentia do corpo da praça, posto que as de Holanda as venção na multidão, e bondade das obras exteriores, como diz Antonio de Ville no seu governador de praças Cap. ${ }^{\circ} 15$ pagina 94, onde se póde ver, o qual estende a fechante ainda a mayor comprimento, mas o sobredito he bastante, principalmente, porque nem todos os mosquetes são reforcados.

\section{Cap. $^{\circ} 13 .^{\circ}$}

DAS DEMIGOLAS.

As demigolas são aquellas linhas que formão o interior da praça, sobre as quais assenta o corpo do baluarte, e pellas quais se entra nelle de sua grandeza depende a grandeza das faces, e de todo o corpo do baluarte, pello que se deve fogir de que rezultem pequenas; porque sendo assim não haverá lugar para formar os flancos altos e bayxos, com seus parapeytos, ficando bastante praça para recuarem os canhões, e passagem da gente como bem se deve segundo diremos adiante.

O corpo do baluarte rezultará tão pequeno que hu'a mina levará a maior parte delle; assim mesmo hu'a bomba o offenderá todo com grande danno dos defensores.

Tambem se deve fogir que sejão demaziadamente grandes, porque será necessario ou fazer os flancos muyto pequenos, ou o angulo flanqueado muyto agudo ou afastar muyto hum baluarte 
do outro e assim fazer as fexantes compridas fóra da boa defença do tiro de mosquete, o que tudo são defeytos consideraveys pelo que para seguir hu'a justa mediania na grandeza das demigolas alguns querem que sejão iguais a sexta parte do lado do poligono interior; outros antes a quinta que a sexta parte do dito lado, outros a outra proporção varia; como quer que seja a experiencia e uzo tem aprovado que será bom fazellas com alguma ventagem mayores que os flancos, ou ao menos nunca menor que estes, segundo trazem por regra estabelecida Mathias Dogen liv. $1^{\circ} \mathrm{Cap}^{\circ}$ 15. Niculao Glodman [Goldman] ${ }^{35}$ livr. $^{\circ} 1^{\circ}$, Cap. 15 com a mayor parte dos modernos.

Cap. $^{\circ} 14 .^{\circ}$

\section{DAS CORTINAS.}

Cortina he o lanço de muralha que fica entre os flancos de dous baluartes proximos; alguns as fabricão com hum angulo no Est. 9. ${ }^{a}$ meyo sahido para fora, como se vê na figura 16, mas tem hum inconveniente de que cada hu'a das linhas GK, YK não fica defendida reciprocamente de ambos os flancos GF, YL, mas so de hum, e nem ainda bem, por se não poder descobrir do flanco GF (em razão de sua altura e grossura de seu parapeyto) a raiz de todo o

\footnotetext{
${ }^{35}$ Tratadista militar holandês, Nicolas Goldman (1611-1665) foi arquiteto e engenheiro militar destacado, muito referido entre os engenheiros e tratadistas portugueses. Era professor de arquitetura militar e civil, muito conhecido neste último campo de atividade pela descrição e traçado que conseguiu dar à voluta jônica. Escreveu numerosos e importantes trabalhos. Homem de grande erudição, no prefácio de sua obra mais conhecida $L a$ nouvelle Fortification, publicada em Leiden pela Elsevier, 1645, estabelece as relações entre história humana, planejamento das cidades e arquitetura militar. É um texto com feição muito didática, apreciado pelos especialistas da matéria.
} 
lanço GK: o mesmo se entende do lanço YK a respeyto do flanco YL; tambem não fica hum flanco visto do outro em razão da promoção do angulo GKY.

$\mathrm{O}$ mesmo inconveniente corre contra as cortinas em arco com a superficie convexa para fora como se ve na mesma figura com o arco GKY.

Pelo contrario as fabricão outros com hum angulo reintrante como mostra a mesma figura, porque dizem que assim cada hum dos lanços GM, YM fica servindo de muyto mais cómodo flanco secundario, do que se a cortina fora toda recta, poys que nos ditos lanços se accommodará melhor a artelheria, e as canhoneyras, ficarão com menos obliquidade: porem para isto era necessario que as razantes viessem demandar o meyo da cortina, o que não pode ser nas praças de poucos baluartes sem hu'a demaziada agudeza dos angulos flanqueados; nem aquellas conveniencias são tays que por ellas desprezemos o mayor custo que estas cortinas fazem mais do que as rectas, e a estreyteza que cauzão na praça; alem de que a sua obliquidade impede poderem ser varridas commodamente com os tiros dos flancos, assim como o são as rectas: nem nestas he o defeyto das canhoneyras tanto que se não possa remediar atirando a artelheria a barba ${ }^{36}$ amparada de sestões (chamão artelheria a barba quando atira por sima do parapeyto, como diremos quando se tratar da defença).

\footnotetext{
${ }^{36}$ Atirar $\grave{a} \mathbf{b a r b} \boldsymbol{a}$, como informa posteriormente o autor, é uma expressão de origem italina que quer dizer atirar sobre parapeitos que não possuem canhoneiras e merlões. Estes parapeitos são, conseqüentemente, mais baixos, permitem maior versatilidade no direcionamento do tiro da artilharia, mas deixam os serventes da peça mais expostos ao fogo do inimigo. O nosso Forte do Mar ou de Nossa Senhora do Pópulo e São Marcelo tinha, como se vê na iconografia antiga, um parapeito com canhoneiras, mas foi, posteriormente transformado, possivelmente no Século XIX, em parapeito à barba ou à barbeta . O Fortim de S. Diogo, no Porto da Barra, é outro exemplo de parapeito à barbeta.
} 
O mesmo se entende contra as cortinas em arco com a superficie concava para fora, como mostra a mesma figura com o arco occulto GMY.

Fig. ${ }^{a} 17$ Est. $9{ }^{a} \quad$ Fabricarão outros as cortinas divididas em tres partes (e ainda em mais) como se vê na figura 17, e a este modo chamarão fortificação reforçada, mas contra elle se oppoem Mathias Dogen, e diz assim. Se o baluarte A se defende cômodamente do baluarte B, para que são necessarios os outros flancos EC, DT. Os quais são de grande custo, estreytão a praça, e fazem os baluartes muyto agudos, porque neste cazo a razante $\mathrm{CP}$ necessita ser tirada dos dous terços da cortina no ponto D se a cortina corresse seguida de $\mathrm{G}$ athe Q; ou quando se queyra evitar a agudeza dos baluartes será forçozo fazer os quatro flancos muyto curtos, que he outro inconveniente.

E se hum baluarte não fosse defendido do outro pella muyta distancia, que he a cauza porque ordenarão semelhante fabrica, não se remedea com ella esta falta, porque o lanço DQ não póde ser defendido do flanco IG [EG] por se suppor em muyta distancia, e menos o póde ser do flanco EC, por ficar a defença impedida da oppozição que lhe faz o flanco DT; não se remedea logo aquella falta com a fabrica da cortina nesta forma, e fasse mayor gasto, e estreytase mais a praça.

Vendo outros que por este modo se não remediava a falta de hum baluarte não poder defender o outro pella muyta distancia fizerão a cortina quazi na mesma forma, mas com esta differença que retirarão os dous lanços RH, KN para dentro de modo que fassão com os flancos FR, LN os angulos obtuzos FRH, LNK segundo se ve na figura 18, em razão de que dos novos flancos $\mathrm{HX}, \mathrm{KZ}$, que ficão na parte media da cortina se defendecem as outras duas partes $\mathrm{RH}, \mathrm{KN}$; porem esta fabrica tem os mesmos inconvenientes de ficar cada hum dos flancos pequenos, a praça estreyta, e tambem os baluartes; 
o gasto grande, a que se acrescenta que assentando os flancos em angulos obtuzos sobre os lanços $\mathrm{RH}$, e $\mathrm{KN}$ ficará a artelheria mais descuberta, e exposta a ser desmontada.

Pello que aprovamos e temos as cortinas rectas pellas melhores, por não terem nenhum dos inconvenientes sobreditos, e serem de todos os modernos aprovadas: porem não obstante se podem em alguns cazos admitir com angulo reintrante, ou partidas em tres lanços com seus flancos duplicados, quando suceda fortificar algum sitio irregular em que seja necessario afastar algum pouco mais os baluartes por occupar com elles lugares mais altos, ou por outra cauza, como seja por fogir de algum máo fundamento em que seja mais dificultozo, e custozo fundar a cortina se póde esta retirar para dentro por algum dos dous modos das figuras 17 e 18, evitando sempre com bom juizo a estreyteza da praça, e baluartes, e juntamente a muyta agudeza de seus angulos flanqueados.

Para determinar o comprimento da cortina total recta digo que não deve passar de 500 pês [ $165 \mathrm{~m}]$ pello mayor termo, nem bayxar de 100 [33m] ainda nos mais pequenos fortes quadrados, onde o sitio não puder permitir mayor largueza, que podendo ser não he bom restringir a tão pequenos termos, posto que os AA [autores] assim o admitão.

$\operatorname{Cap.~}^{\circ} 15 .^{\circ}$

DOS FLANCOS OU TRAVEZES

He a primeyra maxima da fortificação que aquella praça he melhor fortificada a qual he melhor flanqueada [grifo nosso], e por tanto são os flancos a mais importante parte da forti- 
ficação, dos quais depende a defença das outras, principalmente das faces, que por serem mais sahidas a campanha, (e por esta cauza ordinariamente mais accommetidas) necessitão mais da ajuda dos flancos; os quais são em duas sortes diferenciados, segundo o effeyto, em flancos rectos, e oblicos; outros the chamão flancos primeyros, e segundos, ou em termos mais introduzidos flancos primarios, e flancos secundarios aquelle he levantado sobre a cortina no extremo da demigola athe topar com a face do baluarte se chama flanco recto; ou porque ordinariamente cahe em angulos rectos sobre a cortina, ou porque mais rectamente defende a face: flanco primario, por ser mais principal, e aquelle espaço que fica entre a linha razante e o extremo do flanco recto se chama flanco obliquo, por ver mais obliquamente a face; e flanco secundario por ser menos principal na defença.

Devidese tambem o flanco conforme a situação em flanco alto e bayxo; e segundo os accidentes exteriores em flanco cuberto, e descuberto, mas destas devizões diremos melhor quando se tratar da orthografia ou perfil.

A sua dispozição foy varia segundo o capricho de varios Fig. ${ }^{a} 19$ Est. $^{a}{ }^{9}{ }^{a}$ auctores; os Francezes no principio com Erad [sic] de Barleduc ${ }^{37}$ os dispuzerão de modo que formassem angulo agudo com a corti-

\footnotetext{
${ }^{37}$ Jean Errard de Bar-le-Duc (1554-1610) foi o pai da Escola Francesa de fortificar. A rigor, nada apresenta de novo em relação aos fortificadores italianos que trabalhavam, até então, na França. Exibe, todavia, o mérito incontestável de ser o primeiro tratadista francês a sistematizar o desenho moderno das fortificações. Nascido de uma família de Lorraine estudou matemática e fortificação na Itália. Serviu nas guerras de Henrique IV durante uns vinte anos, em importantes missões militares em Sedan, Calais, Amiens, Guise, Metz, Reims e onde quer que o seu trabalho fosse necessário. Em 1599, pelos relevantes serviços prestados à Sua Majestade, recebeu título de nobreza e a mercê de Engenheiro Ordinário do Rei para a Picardia e Île-de-France. Acreditava que a prática sem a teoria era cega e que a teoria sem a prática era desajeitada, aliás, um conceito bem vitruviano. As suas andanças pela Itália e, certamente, a leitura de tratadistas da arquitetura italiana, fizeram-no um especulador do desenho da Cidade Ideal, para a qual se conhecem representações de propostas suas.
} 
na, e recto com a face do baluarte, como o flanco NS perpendicular sobre a face SP, o qual com a cortina faz o angulo agudo QNS; a razam era, porque deste modo ficavão mais cubertos, vendo-os o inimigo, mais obliquamente.

Porem logo deyxavão esta dispozição vendo a diminuição que cauzavão nas demigolas, com que se estreytavão muyto as praças dos baluartes, e que se bem ficavão mais cubertos, e o inimigo os descobria mais obliquamente, o mesmo inconveniente era para os defensores, que dos mesmos flancos disparavão a artelheria, e mosquetaria para as faces dos baluartes oppostos. Tambem diz Antonio de Ville contra este modo que se houvessem de fazer canhoneyras ficarião tão obliquas que não terião força, e a obliquidade ainda seria mayor quando o flanco fosse cuberto com orelhão ${ }^{38}$, por onde ou seria necessario fazer este pequeno e fraco, ou sendo em sua conta tornaria inutil o flanco.

O Conde de Pagan ${ }^{39}$, e outros muytos que escreverão depoys delle [deve estar se referindo a Errard de Bar-le-Duc] (os quais

\footnotetext{
${ }^{38}$ Orelhão he um corpo sólido de figura redonda, e avançado sobre a espalda do baluarte para cobrir o canhão [...] é o que diz Azevedo Fortes.
}

${ }^{39}$ Blaise François, Conde de Pagan (1604-1665), além de ser um tratadista francês, dos mais respeitados, que apresentou propostas de fortificações realmente novas para a Escola Francesa, a sua vida é qualquer coisa de fascinante e dramática. Com 12 anos, já estava no exército (1616) e sua experiência como combatente foi das mais intensas. Participou dos assédios de Caen e S. Jean d'Angely (1620); no de Montauban (1621), perdeu um olho. Participou dos sítios de La Rochelle (1627) e Nancy (1633) com Luis XIII e das campanhas de Flandres e Picardia com De Ville. Em 1642, perdeu o outro olho em combate, ficando completamente cego aos 38 anos, quando já era Marechal de Campo. Nem por isto o infortúnio the abateu o ânimo. Continuou os seus estudos matemáticos e sua casa era uma espécie de academia dos cultuadores das ciências e das letras. Ao entregar-se ao Criador, em 1665, foi assistido, no leito de morte, pelo médico do próprio Rei, uma demonstração do seu grande prestígio. O seu famoso tratado de fortificações dedicado a um antepassado, Hugues Pagan, um dos fundadores dos Templários, entre outros trabalhos que escreveu, é texto obrigatório para os estudiosos da história das fortificações; é um livro para quem já conhece o básico dos sistemas fortificados, com reedições e tradução em outras línguas, além do francês. 
quazi todos o imitarão) fabricou os flancos de modo que formassem angulos obtuzos com a cortina, mas de sorte que cahissem perpendiculares sobre a linha razante no mesmo angulo da cortiFig. ${ }^{a} 19$ Est.9." na e flanco, como QS o qual he perpendicular sobre a razante QSP, e com a cortina forma o angulo obtuzo SQN; a razão foy, porque assim ficavão rectos a face, e podendo-a descobrir e varrer mais eficazmente com tiros parallelos.

Mas contra se lhe oppoem que posto que os defensores fiquem em melhor dispozição para descobrirem a face, fica tambem a artelheria mais exposta as baterias do inimigo, e todo o flanco mais sugeyto ao effeyto della, fazendo-o esta mayor contra elle quando he perpendicular á razante, do que quando he perpendicular á cortina, pello bater com tiros mais rectos que são os que fazem mayor impulso e força, e as canhoneyras ficão mais sugeytas a serem embocadas.

Pello que os Holandezes se não quizerão afastar de assentarem os flancos em angulos rectos sobre as cortinas, como tambem uzarão sempre os italianos, porq' seção [sic] os inconvenientes de ficarem as canhoneyras muyto obliquas, como no primeyro modo, ou muyto expostas, como no segundo modo, podendoselhe bem aplicar os orilhões para melhor os cobrir; e tambem porque (como diz Dogen liv. $1 .^{\circ}$ Cap. $^{\circ} 5^{\circ}$ axioma 13) os defensores ainda na obscuridade da noute aplicando os peytos sobre os flancos atirão mais direytos varrerão melhor as cortinas hindo os tiros mais parallelos a ellas; mas esta razão de Dogen não he muyto valente, porque a mesma podem dar os que formão o flanco perpendicular a razante, dizendo que por este modo ainda na obscuridade da noute os defensores aplicando os peytos sobre os flancos varrerão melhor as faces que são mais accommetidas que a cortina. 
Nesta variedade não falta quem queyra seguir hu'a mediania; Monsieur Malet ${ }^{40}$ nos trabalhos de Marte forma os seus flancos com hum angulo de 98 graos com a cortina, parecendolhe os flancos do Conde de Pagan muyto abertos, quis tomar algum termo, e elegeu aquelle, que não sey que tenha algum misterio o numero de 98 graos: Monsieur Ozanan ${ }^{41}$ no seu tratado das fortificações tira sempre os flancos do centro da figura, deste modo ficão quazi no meyo entre os perpendiculares á razante, e os perpendiculares á cortina, ficando mais chegados a estes nas figuras de mais lados.

Quem quizer o póde assim fazer nos fortes e praças pequenas, porque alargando as demigolas ganhará algu'a couza mais na praça do baluarte para se poderem engroçar os parapeytos, ficando campo para o manejo da artelheria, e mais funsões melitares; porem nas praças grandes, e de muytos lados, não he de tanta importancia esta emmenda, porque nestas praças ja se suppoem bastante largueza nas demigolas e flancos, e por este modo tambem nas praças dos baluartes; e porque como o angulo de defenção exterior vay sendo menor, vay ficando a defença dos flancos menos obliqua ás faces; pello que nestas ditas praças grandes me parece conservar a dispozição do flanco perpendicular á cortina.

\footnotetext{
${ }^{40}$ O autor deve estar referindo-se a Allain Manesson Mallet (1630-1706), que inclusive, prestou serviços a Portugal no Reinado de Afonso IV. Um dos seus trabalhos mais conhecidos foi Les travaux de Mars ou l'art de la guerre, publicado em Paris no ano de 1685, tornou-se muito popular porque era profusamente ilustrado e em formato reduzido para ser usado em campanha.

${ }^{41}$ Monsieur Ozanam (1640-1717) foi tratadista militar francês e seguidor de Vauban. Seu nome completo era Jacques Ozanam e era de origem judia. Matemático de renome foi membro da Academie des Sciences. O seu principal trabalho sobre fortificações (Traité de fortification contenant les méthodes anicennes et modernes pour la construction et la défense des places et la manière de les attaquer, expliquée plus au long qu'elle n'a été jusques à present) compara diversos métodos de fortificar e foi editado em Paris por Jean Jombert, em 1694.
} 
Nem se poderá replicar que poys aquella praça he melhor fortificada que tem mayores flancos, não se deve desprezar nada pellos fazer grandes, mas fazendo-os em angulos obtuzos com a cortina rezultão mayores, logo assim se devem fazer ainda nas praças grandes, e de muytos lados; porque se responde, que isto seria quando se conseguise a mayor grandeza sem inconveniente, porem por cada pê que se perde no flanco primario fazendo-o perpendicular, se ganhão muytos pês no secundario da cortina.

He porem questão bem problematica para decidir se he melhor diminuir os flancos rectos por fazer os oblicos na cortina grandes, ou fazer os rectos quanto grandes possa ser, posto que nos privemos dos obliquos.

O Conde Pagan, e quazi todos os Francezes que escreverão depoys delle desprezão os flancos na cortina, porque dizem que estes tays flancos são de muyto pouco, ou nenhum serviço na pratica da defença a respeyto da sua muyta obliquidade, e assim testemunha o dito conde que em mais de vinte sitios que vio, não vira matar alguem dos flancos secundarios da cortina, estando o inimigo dentro no fosso, que he para quando os ditos flancos havião de servir: mas esta razão seria boa para não confiar muyto a defença nelles, e não he bastante para de todo os não haver, e em outro lugar diremos porque cauza os seus tiros são de menos pontaria, e o remedio que podem ter: pello que respondo a questão que he melhor nas praças de muytos baluartes fazer hum e outro flanco, a razão he porque conforme o axioma $1^{\circ}$ de Goldman a dobrada defença se deve preferir á singela; mas como o flanco secundario multiplica a defença, logo ambos são necessarios e ambos se devem admetir.

Resta dizer de sua grandeza, e pello que ensinão Dogen, e Goldman, o flanco recto nunca deve ser menor que a quarta parte 
da face, nem mayor que sua a metade; será bom ser mais proximo ao mayor termo que ao menor. O flanco obliquo posto que dizem será melhor quanto grande possa ser sem incomodo das outras partes, a saber sem incomodo do recto, e sem incomodo do angulo flanqueado, que são as partes que podem ser perjudicadas [sic], e assim o querem os ditos AA [autores] estender athe os $2 / 3$ da cortina, com tudo digo que ja será grande se passar de a metade da cortina.

Cap. $^{\circ} 16 .^{\circ}$

\section{DAS FACES.}

As faces dos baluartes são as partes que ficão mais avançadas á campanha, e por tanto mais expostas ao ataque do inimigo; daqui nasce que por ellas he que trata de ordinario de senhoriarse do baluarte, e ganhar a fortaleza, ou arruinandoas com batarias, ou picandoas e fazendoas voar com minas, havendo primeyro para este intento atraveçado o fosso com suas galarias, para depoys pella brecha dar o assalto: por tanto não so he necessario que sejão defendidas de bons flancos primarios e secundarios, mas que em si sejão grandes para que dem lugar a se fazer detras da brecha hu'a e outra retirada, poys de assim serem he força que tambem rezulte a area do baluarte grande, e capaz de nella se fazerem.

Alguns the asignão quantidade certa em todas as figuras; outros as vareão conforme forem de mais ou menos lados: dos que lhe asignão quantidade certa he Dom Diogo de Medina Barba ${ }^{42}$ no seu Exame pag. 24 que em todas as figuras faz sempre a face de 250 pés geometricos ${ }^{43}$

\footnotetext{
${ }^{42}$ D. Diego de Medina Barba Gonzáles, como o nome mesmo sugere era espanhol. Seu trabalho mais conhecido é o Esamen de fortificación editado em Madrid em 1599 e, em seguida, no ano de 1609 .

${ }^{43}$ O pé geométrico, segundo Serrão, vale $0,278 \mathrm{~m}$.
} 
[69,5m]. O Conde de Pagan que poem tres sortes de fortalezas reays, a saber, maxima, mediana, e minima; faz na primeyra a face de 60 toezas $^{44}$, ou 360 pés [118,8m] regios de França ${ }^{45}$; na segunda 55 toezas, ou 330 pés $[108,9 \mathrm{~m}]$, e na terceyra 50 toezas ou 300 pés [99m] em todas as figuras de 5 athe 12 lados, de que so trata em cada hum dos ditos tres generos de fortificação, como se póde ver no Methodo Luzitanico no apendis [sic] sobre as fortificações deste auctor.

O Cap ${ }^{\text {am }}$ Diogo Henriques de Vilhegas ${ }^{46}$ emita nesta parte quazi em tudo ao Conde de Pagan, porque sempre poem certas as cortinas, flancos, e faces, e ainda as demigolas que em Pagan ficão varias.

Os que asignão quantidade varia as faces em fortificação real são Adriano $\mathrm{Mecio}^{47}$, que no quadrado as faz de 256 pés [84,48m], no pentagono de 255 [84,15m], no exagono de 259 [85,47m], no eptagono de 260 [85,8m], no octogono de 247 [81,51m], no eneagono de 244 [80,52m], no decagono de 242 [79,86m], no undecagono de 239 [78,87m], no duodecagono de 231 [76,23m]; mas isto neste auctor he hum mero capricho, porque não ha razão de conveniencia para que a face seja mayor ou menor dous ou tres pés.

\footnotetext{
${ }^{44}$ A toeza franceza antiga equivale a $1,93 \mathrm{~m}$, segundo a Taboada de Combinações de Medidas de Serrão Pimentel (p. 26), acontece que, pela afirmação de Vellozo deveria valer $1,96 \mathrm{~m}$ já que dava uma equivalência de 60 toezas ou 360 pés régios.

${ }^{45}$ Valia, aproximadamente, $0,327 \mathrm{~m}$.

${ }^{46}$ Cav. Diego Henrique de Villegas era espanhol. Teve o título de Comendador da Ordem Militar de Jesus Cristo e Capitão dos Couraceiros Espanhóis. Entre os diversos textos sobre a arte da guerra produziu: Academia de fortificación de plazas y nuevo modo de fortificar uma Plaza real, differente em todo de los demas que escrivieran esta arte, publicado em Madri no ano de 1651.

${ }^{47}$ Estava citando o ilustre astrônomo, matemático, geômetra e médico Adriano Mezio, também versado nas artes da fortificação que, entre outros trabalhos, publicou esta obra de título quilométrico: Arithmetica libri duo, et Geometria libri sex. Huic adjungitur Trigonometria planorum methodus succinta. Altera vero prœter alia nova regula proportionalis inventa proponit; et quaccumque loca adversus hostium insultusjuxta hoc sceculo praxim (quam fortificationem vocant) munire solide docet, publicado em Franeker, em 1625.
} 
Christovão de Rochas ${ }^{48}$, asigna no triangulo 300 pés [99m] no quadrado 310 [102,3m], e nas praças de mayor numero de lados vay diminuindo 20 pés $[6,6 \mathrm{~m}]$ por cada lado, a saber, no pentagono faz a face de 290 pés [95,7m], no exagono de 270 [89,1m], e no pentagono de 250 [82,5m] em que pára.

Monsieur de Vauban (hum dos mayores Engenheyros dos prezentes seculos) ${ }^{49}$ as faz em todos os poligonos de 2/7 do lado exterior, e Antonio de Ville lhe não dá grandeza determinada, e por rezolução deste Cap. ${ }^{\circ}$ dizemos, que não importa que as faces sejam sempre certas em todas as figuras, ou varias, com tanto que tenhão a justa grandeza para que o baluarte rezulte grande e capaz; assim mesmo que tenhão huma determinada semitria com as mais partes da fortaleza, de tal modo que em humas pequem por excesso, nem outras por defeyto: e para esta determinada semetria ${ }^{50}$ diz Goldman que a face não seja menor que a metade da cortina, nem mayor que toda a cortina: e posto que o mesmo Goldman elegeu o primeyro termo fazendo sempre a face a metade da corti-

\footnotetext{
${ }^{48}$ Tradução do espanhol Cristobal Roxas ou Rojas. Este engenheiro militar do Rei da Espanha foi professor da Academia Militar de Madri e considerado como um dos primeiros tratadistas espanhóis. Publicou com o apoio de Francisco Bobadilha, Mestre de Campo dos Exércitos de Felipe II, um tratado de fortificação intitulado Teórica y prattica de fortificación editado em Madri, em 1598, revisto e reeditado em 1613. Publicou também outros trabalhos sobre a ciência militar.

${ }^{49}$ Marechal Sébastien le Prestre de Vauban (1633-1707) é reconhecido por todos os estudiosos como uma das maiores figuras da arte da fortificação e da expugnação das praças. Serviu à França por 56 anos, (principalmente durante o reinado de Luís XIV), chegando ao posto de Marechal. Durante este tempo, restaurou ou reconstruiu cerca de duas centenas de fortalezas e fez 33 novas. Curiosamente, Vauban, embora tenha deixado à posteridade uma série de escritos, não criou um texto específico, acadêmico, da arte de fortificar nem um tratado propondo seus traçados. De certa forma, sabe-se que, como soldado profissional, ele era infenso à divulgação de procedimentos defensivos e ofensivos de caráter militar, que pudessem prejudicar os bons resultados obtidos com o segredo e a surpresa. Deve, também, residir aí a sua genialidade, pois, não tendo modelos preconcebidos, procurava, muito mais, entender e tirar partido da realidade do terreno, apelando para expedientes diversos de várias escolas, que provaram ser eficientes.

${ }^{50}$ Conceitos vitruvianos
} 
na, e a admita tambem menor no irregular, melhor proporção he a de Adão Fritach ${ }^{51}$, a qual tambem segue Dogen liv. $1^{\circ}$ Cap. 15 axioma 17 , que faz a face igual aos $2 / 3$ da cortina, e ainda a admite mayor em certos cazos, com tanto que sempre a fechante fique dentro do tiro de mosquete.

Porem ha alguns AA [autores] que seguem o contrario, a saber, que quanto menor proporção tiverem as faces para a cortina, tanto será melhor; porque dizem que a face he a parte de todo o recinto da fortificação, que menos defende as outras, e que tambem he menos defendida que a cortina; porque esta tem a defença de dous flancos rectos, e aquella a de hum só; pello que quanto for menor tanto será melhor, porque haverá menos que defender; mas a isto se responde que se he defeyto ser a face menos defendida que a cortina, não se remedea este defeyto com se fazerem menores, antes se the tira a valentia que devem ter para que o baluarte rezulte grande, e possa alojar muytos defensores, por tanto sem embargo da razão contraria he melhor peccar nesta parte antes por excesso, do que por defeyto, e assim aprovamos antes a proporção mayor do que a menor da face para a cortina.

\footnotetext{
${ }^{51}$ Adam Freytag [ou Fritach] (1602-1664) foi um destacado engenheiro, cuja obra escrita soube bem definir os postulados da Escola Holandesa. O seu nome aparece, constantemente, nos textos e relatórios de engenheiros portugueses dos Séculos XVII e XVIII, muitos dos quais serviram temporariamente ou seguiram a sua carreira no Brasil. Seu tratado é um clássico e, sobre ele, se refere Marini: (...) $\S 2^{\underline{0}}$ As múltiplas edições deste livro demonstram a estima que ele conseguiu entre os leitores. A obra mais importante de Freytag foi L'Architecture militaire ou la fortification nouvelle, editada em Paris em 1640 e, logo em seguida em Leiden, com o título de Architectura militaris nova et aucta, oder newe vermehrte Fortification, com data de 1642.
} 


\section{Cap. $^{\circ} 17 .^{\circ}$ \\ DO ANGULO FLANQUEADO \\ QUAL HE MELHOR SE AGUDO, RECTO OU OBTUZO.}

Sobre a determinação do angulo flanqueado ainda não estão athe agora concordes os AA [autores]. Erard de Barleduc, Simão Estevino, e mais antigo Iacome Castrioto ${ }^{52}$, com outros do seu tempo preferirão os obtuzos podendo ser aos rectos, ou agudos, e a razão era porque assim dizião que ficavão mais fortes contra os golpes da artelheria, poys sendo de mayor circumferencia ficava em si mais robusto, do que se fosse recto, ou, agudo.

Encontrou esta razão Antonio de Ville, o qual pertende [sic] provar e outros mais, que o baluarte rectangulo he melhor que o obtuzangulo, porque fica mais defendido, e tambem fica mais capaz; porque se o inimigo intentar romper o angulo flanqueado necessita de arruinar mayor proção [sic], sendo o angulo recto, do que sendo obtuzo para se cobrir igual numero de gente; e finalmente porque os tiros que se fazem do flanco á face do baluarte são mais fechantes, e descobrem mais a brecha na dita face, que na do baluarte obtuzangulo.

A primeyra razão que o baluarte de angulo recto fica mais defendido que o de angulo obtuzo suppostos os mesmos flancos e demigolas, se prova, porque a face $\mathrm{BC}$ do baluarte rectangulo

\footnotetext{
${ }^{52}$ Refere-se a Giacomo Fusto Castrioto originário de Urbino, um dos mais importantes pioneiros da fortificação italiana. Trabalhou muito para o papado fortificando diversas cidades do Estado Pontifício tanto na gestão de Paulo III, quanto de Júlio III. Era muito estimado por Carlos V da Espanha. Trabalhou bastante na França tornando-se, inclusive o Superintendente Geral das Fortalezas do Reino. Dos muitos assédios de que participou, sempre demonstrou grande engenhosidade e coragem. O seu trabalho escrito mais conhecido é Della fortificatione delle città Libre tre, editado em Veneza no ano de 1564. Este trabalho mereceu recentemente uma belíssima edição facsimilada por Jouvence-Viella, com apresentação de Giorgio Ferrari.
} 
Fig. 20. Est. $10^{a} \mathrm{ABCDR}$ he defendida do flanco primario GH, e do secundario GF; e a face BK do baluarte obtuzangulo ABKDR he somente defendida do flanco primario GH suppostos os mesmos flancos $\mathrm{AB}, \mathrm{RD}$; e as mesmas demigolas AO, e OR em hum e outro; e supposto que entre os pontos $\mathrm{K}$ e $\mathrm{C}$ se podem formar diversos angulos obtuzos que sejão defendidos de pontos da cortina entre $\mathrm{G}$ e $\mathrm{F}$ e por tanto sejão defendidos de flancos secundarios, todavia isso será quando os tays angulos obtuzos forem pouco mayores que rectos, e nunca terão tão grande flanco secundario como GF.

A segunda razão de que o baluarte rectangulo he mais capaz se prova porque lançada a linha $\mathrm{BD}$, e considerado o triangulo rectangulo $\mathrm{BCD}$, as linhas $\mathrm{BK}$, DK que sahindo dos mesmos extremos $\mathrm{B}$ e $\mathrm{D}$ concorrem no ponto $\mathrm{K}$ dentro nelle formão mayor angulo $\mathrm{BKD}$, e por tanto obtuzo (pella prop. 21 do $1^{\circ}$ de Euclides) mas o triangulo $\mathrm{BKD}$ será menor que o triangulo $\mathrm{BCD}$ pello trapezio BKDC, por onde ajuntando a cada hum dos ditos triangulos o pentagono irregular OABDR rezultará o baluarte rectangulo ABCDR mayor que o baluarte obtuzangulo ABKDR pello dito trapezio $\mathrm{BKDC}^{53}$, em que se podem alojar mais soldados, e fazer mais cortaduras ${ }^{54}$.

A terceyra razão de que sendo o angulo flanqueado recto necessita o inimigo de romper mais do baluarte do que se fora obtuzo para se cobrir igual numero de gente, se demonstra, porque supponhamos que he necessario cortarse do angulo flanqueado

\footnotetext{
${ }^{53}$ Observe-se a domínio da geometria Euclidiana. Alguns tratados de fortificações vinham precedidos ou sucedidos de lições de geometria que eram consideradas fundamentais pela engenharia militar da época.

${ }^{54}$ Cortaduras são humas trincheiras fortes com seus foços, que se fazem por dentro das brechas nas obras em parte arruinadas. Esta é a definição que nos dá Azevedo Fortes no capítulo dedicado às definições. Como se vê, é um expediente para barrar o inimigo quando este abre uma brecha nos muros.
} 
athe a linha YX de 45 pés $[14,85 \mathrm{~m}]$ que se requerem de frente para hirem 15 homens ao assalto; sendo poys o angulo $\mathrm{C}$ recto será no triangulo YCX o quadrado de YX igual aos quadrados de YC, e CX (pella prop. 47 do $1 .^{\circ}$ de Euclides) por tanto tirando a raiz quadra de a metade do quadrado de YX esta raiz manifestará o valor do lado YC, ou CX de 31 pés [10,23m] e 8/10 de pé [0,264m]: mas no triangulo obtuzangulo YKX suppondo o angulo $\mathrm{K}$ de 110 graos por exemplo, sahirá pellos perceytos [sic] da Trigonometria o lado YK de 27 pés $[8,91 \mathrm{~m}]$ e 4/10 de pé $[0,132 \mathrm{~m}]$ menor que o lado YC por 4 pés $[1,32 \mathrm{~m}]$ e $4 / 10$ de pé $[0,132 \mathrm{~m}]$, o qual numero dobrado faz 8 pés [2,64] e $8 / 10$ de pé $[0,264 \mathrm{~m}]$ que tanta quantidade he necessario ao inimigo romper de mais nos dous lados $\mathrm{YC}$, e CX, do que nos outros dous YK, e XK para chegar a fazer a frente YX de 45 pés $[14,85 \mathrm{~m}]$ que são necessarios para o assalto de 15 homens por frente; alem disto necessita o inimigo de desfazer mais terra no triangulo $\mathrm{YCX}$, do que no triangulo $\mathrm{YKX}$, poys a area superficial daquelle contem 505 pés quadrados e $62 / 100$ de pé $\left[55,05 \mathrm{~m}^{2}\right]$, e a deste 351 pés e $82 / 100\left[38,31 \mathrm{~m}^{2}\right]$ menor por 153 pés quadrados e $8 / 10$ de pé $\left[16,74 \mathrm{~m}^{2}\right]$.

A quarta razão de que os tiros feytos dos flancos são mais fechantes a face do baluarte rectangulo, que á do obtuzangulo se demonstra porque sahindo do ponto S a linha SRO que corte as Fig. ${ }^{2} 21$ Est. $10^{a}$ duas faces, a saber DC do baluarte rectangulo no ponto $\mathrm{R}$, e DK do baluarte obtuzangulo no ponto $\mathrm{O}$; o que supposto porquanto no triangulo DRO o angulo externo DRS he mayor que o interno DOR, e por tanto o reliquo SRX o qual he complemento do angulo DRS para o recto DRX será menor que o reliquo SOZ o qual he complemento do angulo DOS para o recto DOZ, pello que o angulo DRS se chega mais a recto do que o angulo DOS, e por tanto 
a linha SR fere a face DC no ponto $\mathrm{R}$ mais proximamente á perpendicular RX, do que fere a linha SO a face DK no ponto $\mathrm{O}$ a respeyto da perpendicular OZ; a mesma prova corre em todas as maia linhas que se tirarem de qualquer ponto do flanco TS ás ditas faces DC, DK: logo o tiro do flanco á face do baluarte rectangulo he mais fechante do que a face do baluarte obtuzangulo, que he o que intentámos provar.

Diz mais o dito Antonio de Ville que o mesmo baluarte rectangulo he melhor que o accutangulo, porque este não reziste igualmente á bataria perpendicular como succede no recto, segunEst. $10^{a}$ do se ve na fig. 22 em que as linhas ZOD, HRG perpendiculares á face OD do baluarte acutangulo o cortão muyto differenteme ${ }^{\text {te }}$, porque a primeyra acha de rezistencia o espaço OD, e a segunda o espaço RG muyto mayor; o que não succede nas linhas $\mathrm{LMN}^{55}$ perpendiculares á face $\mathrm{YQ}$ do baluarte rectangulo $\mathrm{YQX}$, poys contra o golpe de qualquer dellas fica opposto todo o corpo do baluarte inteyro.

Os Holandezes vendo que esta razão que prefere o baluarte rectangulo ao accutangulo não convence, porque a ella se responde que a bataria não póde imprimir impulso em todo o corpo do baluarte, nem na sua quarta parte, por onde ainda nos baluartes accutangulos ha bastante corpo para rezistir, como se tem visto por experiencia em muytos sitios principalmente quando hoje se trata antes de encaminhar a bateria á parte mais proxima do angulo da espalda, que á parte mais proxima do angulo flanqueado; com que ou este seja agudo, ou obtuzo importa pouco na pratica a concideração da mayor rezistencia pello mayor corpo opposto á bateria.

\footnotetext{
${ }^{55}$ Parece que as letras M estão deslocadas da sua posição no desenho.
} 
Vendo tambem que todas as razões asima que caleficão [sic] o baluarte rectangulo por melhor que o obtuzangulo; militão tambem em favor do accutangulo, mais que do rectangulo, e muyto mais que do obtuzangulo, segundo se póde ver aplicando as mesmas demonstrações, por tanto excluindo o obtuzo, o admitem so agudo, ou recto, com a diversidade porem de pareceres que se seguem.

Tomão alguns a terça parte do angulo da figura regular a que se quer aplicar o baluarte e á dita terça parte ajuntão sempre por regra geral 30 graos, e de tantos fazem o angulo flanqueado.

Desta fabrica se segue que em nenhu'a figura regular poderá haver angulo flanqueado que chegue a 90 graos; a razão he porque como qualquer angulo deve ser sempre menor de 180 graos, será a sua terça parte sempre menor de 60, e ajuntandolhe os 30 da regra geral rezultará a somma sempre menor de 90, e assim os auctores desta opinião so ficão formando recto o angulo flanqueado quando o baluarte assenta sobre linha recta, que se chama baluarte plano, não porque não seja como os outros, mas porque assenta em linha direyta, e não sobre angulo.

O mesmo em substancia, mas com muyto rodeyo seguio ultimamente Monsieur Blonde ${ }^{56}$ em hum discurso que intitulou nova maneyra de fortificação de praças impresso no anno de 1684, a saber do angulo da figura tira por regra geral hum angulo recto ou 90 graos, do que resta toma a terça parte a que ajunta 15 graos para desta somma fazer angulo diminuto cujo dobro tirado do angulo da figura resta por valor do angulo flanqueado o mesmo que na opinião asima.

\footnotetext{
${ }^{56}$ Blondel foi importante tratadista francês, arquiteto civil e militar. Entre as muitas funções que exerceu na vida foi professor de matemática do filho do Rei, Membro da Real Academia de Ciências de Paris, Diretor da Academia de Arquitetura, Conselheiro de Estado, Marechal de Campo dos exércitos do Rei da França e outras funções. O seu trabalho mais famoso intitula-se: Nouvelle manière de fortifier les places, editado na França em 1683.
} 
Outros seguindo a Samuel Maroloes [Marolois] ${ }^{57}$ ajuntão sempre por regra geral 15 graos a metade do angulo da figura, e quando isto somma de tanto fazem o angulo flanqueado athe que chegue a ser de 90 graos, porque dahi não passão, pondo sempre o mesmo angulo de 90 graos em todas as mais figuras que se vão seguindo.

Conforme esta fabrica rezulta o angulo flanqueado no quadrado de 60 graos, na figura de 12 lados de 90, o qual conservão em todas as mais figuras de mayor numero de lados.

Ha outros que á metade do angulo da figura ajuntão 25 graos, e conforme esta somma fazem o angulo flanqueado, de que rezulta no quadrado de 70 graos, e no octogono passa ja de 90 , o qual conservão recto nesta e nas mais figuras seguintes.

Alguns tomão os $2 / 3$ do angulo da figura, e tanto que chega a 90 graos retem sempre este angulo para os baluartes de todas as mais figuras de mayor numero de lados.

Outros formão o angulo flanqueado no quadrado de 65 graos, e logo vão acrescentando mais 5 graos em cada hu'a das figuras que se vão seguindo, de modo que no pentagono o fazem de 70 graos, no exagono de 75, no eptagono de 80, no octogono de 85, no eneagono de 90 , o qual conservão em todas as mais figuras que se seguem.

\footnotetext{
${ }^{57}$ Samuel Marolois (1572-1627) foi um grande matemático, de origem francesa, conhecido, enquanto vivo, como o Príncipe dos matemáticos. Também foi mestre destacado da fortificação, viveu a maior parte da sua vida profissional na Holanda e, como tal, participante da Escola Holandesa. Desenvolveu um sistema de fortificação baseado no de Francesco d'Marchi, que inspirou bastante os engenheiros holandeses. Seu trabalho principal foi publicado em diversas línguas, inclusive o inglês. O texto mais famoso que produziu foi Fortification ou Architecture militaire tant offensive que defensive. Haya: Henrik Hondius, 1615. Entre 1627 e 1628, saíram edições em holandês, alemão e latim e foram feitas edições revistas e ampliadas durante muito tempo. O seu sistema foi básico para os fundamentos da Escola Holandesa.
} 
Adam Fritach segue o meyo entre os que acrescentão 15 graos, e os que acrescentão 25 á metade do angulo da figura, porque elle acrescenta 20 athe a figura de 9 lados em que ja por este modo chega a ser recto, o qual tambem conserva em todas as mais figuras.

Em sustancia vem a ser que fazem todos estes AA [autores] o angulo flanqueado desde 60 graos athe 90, excluindo o obtuzo contra a opinião dos antigos que o preferião podendo ser ao recto, ou agudo.

De todas estas opiniões se me fora necessario para ordenar o desenho determinar primeyro o angulo flanqueado elegera o parecer de Samuel Maroloes que acrescenta 15 graos ao semiangulo da figura, não parando porem no angulo recto como elle faz, mas continuando por diante athe 105 graos, conforme rezulta desta regra quando o baluarte assenta sobre linha recta.

E por concluzão digo que não importa que o angulo flanqueado per si so considerado sem aplicação a esta ou áquella figura seja agudo, recto ou obtuzo, com tanto que tenha amigavel conrespondencia com as partes defendentes da fortificação como se requereo no axioma $9 \mathrm{Cap}^{\circ} 6^{\circ}$, e assim não se dilate com perjuizo dellas, nem tão pouco se diminua de modo que em si fique fraco; vem a ser, que nem seja muyto agudo, nem demaziadamente obtuzo.

E para determinar poys dentro em que termos se deve incluir digo que não deve ser menor de 60 graos que he 1/3 menor do angulo recto, nem tambem deve ser mayor de 120 graos, que he $1 / 3$ mais do angulo recto.

Porem considerando ja com aplicação a alguma fig. a qualquer dos tres angulos agudo, recto, ou obtuzo, poderá ser melhor que os outros, a saber o agudo em muytas figuras será melhor que 
o recto, e muyto melhor que o obtuzo, e este melhor em outras figuras que o recto, ou agudo, mas o recto em alguma figura melhor q' hum e outro: a saber nas figuras menores de 12 lados, será o angulo flanqueado agudo melhor que o recto, e muyto melhor que o obtuzo: para as figuras de mais de 12 lados athe a linha recta sera melhor o obtuzo que o agudo, ou recto, e este melhor no duodecagono, e com pouca differença nas figuras proximas a elle; porque assim como rezultão inconvenientes de o fazer recto nas figuras de menos de 12 lados, a saber que nestas se diminue muyto o flanco secundario (salvo quizermos diminuir do primario para conservar o secundario, o que não convem, e he melhor diminuir do angulo flanqueado) as faces rezultão pequenas a respeyto da cortina; assim tambem rezultão inconvenientes conservando o angulo flanqueado recto nas figuras de mais de 12 lados, a saber que vay crescendo muyto o flanco secundario, salvo quizermos estender mais o primario (mas se assim remediamos hum inconveniente daremos em outro, que he a estreyteza das golas) as faces vão sendo mayores a respeyto da cortina podendose fazer menores alargando hum pouco o angulo flanqueado, pello que este se não deve conservar recto nas ditas figuras de mais de 12 lados, como tambem não he bom que chegue a recto nas figuras menores de 12 lados.

Nem obstão as demonstrações assima em abono dos baluartes rectangulos contra os obtuzangulos, porque se responde quanto á primeyra que supposto que o baluarte rectangulo seja mais defendido que o obtuzangulo pella mayor commodidade que tem para ter mayores flancos na cortina, com tudo como estes nas figuras de mais de 12 lados sejão bem grandes, ainda sendo o baluarte obtuzangulo não importa, antes não he tam bom fazelos mayores, 
por cuja cauza não aprovo flanco secundario mayor que a metade da cortina, como se disse no fim do cap. ${ }^{\circ}$ antecedente.

O mesmo se responde á segunda, poys como nas ditas figuras mayores posto que o baluarte seja de angulo obtuzo he ja de bastantissima praça, aquelle pequeno acrescentamento que the rezultaria com o angulo recto não servia de mais que de multiplicar o gasto no mayor comprimento das faces, e nos terraplenos que demais serião necessarios.

Em quanto á terceyra razão que necessita o inimigo de romper mais muralha junto do angulo flanqueado recto que obtuzo para fazer igual largura de brécha respondese que he couza de pouco momento quando os angulos não são demaziadamente obtuzos; o mesmo se diz á quarta e ultima razão de ficarem os tiros dos flancos mais fechantes á brecha; por onde nenhu'a d'aquellas razões impede o admitirem-se os angulos obtuzos salvo naquellas figuras a onde não convem.

E não se deve oppor que permitindose o angulo flanqueado athe 120 graos se contradiz o parecer de Marolois o qual asima se aprovou por melhor q' os outros, conforme o qual nunca o angulo flanqueado póde passar de 105 graos; porque se responde q' quando se diz que não deve ser mayor de 120 graos ainda que se aprova poder chegar a este termo não se nega que sendo de menos seja melhor; pôsse aquele numero de 120 graos para se dizer que athe aquella abertura não ha defeito da parte do angulo, e tambem por respeyto das figuras irregulares, nas quais muytas vezes póde ser necessario chegar áquelle termo: nas regulares onde não ha esta necessidade mais agradavel será não passar de 105 graos; e d'aqui se segue a razão por onde ainda nas figuras irregulares se dizia que se não permitisse que a hum angulo de hu'a figura menor se avezinháse outro de outra 
figura mayor que o duplo do numero dos lados da menor, para que o angulo flanqueado não fosse mayor de 105 graos, ou proximamente, e que quando não se pudesse assim accommodar ao menos junto de hum angulo menor não ficasse outro mayor que o da figura tripla da menor para que nunca o flanqueado passasse de 120 graos, que para este cazo he que se alargou athe aquelle termo.

\author{
Cap. $^{\circ} 18 .^{\circ}$ \\ DA GRANDEZA DO LADO DO POLIGONO \\ EXTERIOR, E TAMBEM INTERIOR PARA SE \\ FORTIFICAREM COM BALUARTES INTEYROS.
}

A grandeza de todas as linhas da fortificação assim reáes, como imaginarias rezulta da grandeza do lado exterior, ou tambem interior; a grandeza destes se governa, e absolutamente depende da grandeza, ou distancia da linha fichante, dita por antonomásia a linha da defença; e deste modo, e com attenção á dita linha da defença he que todos se governão na determinação dos ditos lados exterior, e interior: as razões são as mesmas que ja se derão quando se tratou da mesma linha no Cap $^{\circ} 12$ as quais se podem aqui accommodar, poys que debalde se alargarião mais os baluartes se pella muyta distancia de hum se não chegase a defender de hum a outro; donde vem que não devemos admittir mayor lado exterior, nem tão pouco interior, que delle rezulte a defensa fóra do tiro de mosquete, que he por onde a linha fichante se regula.

Mas porque nem todas as fortificações podem ser de hu'a mesma grandeza, Niculao Goldman liv. $1^{\circ}$ definição 9 as dividio em reais, que são quando as defenças se terminão a todo o alcance 
do mosquete; em dodrantais, que são quando a defença se termina aos tres quartos do alcance do mosquete; e em dimediatas quando a defença he conforme á metade do dito alcanse, e em quadrantais quando a defença he segundo a quarta parte do dito tiro: as que não são justamente nem iguais aos $3 / 4$, nem ao $1 / 2$ nem á quarta parte do tiro de mosquete chama intermedias ${ }^{58}$.

A razão desta divizão tomou o dito auctor da divizão da libra que os Romanos (como outra qualquer couza inteyra[)], ou fosse corporia, ou incorporia como a erança dividião em 12 onças, dando a cada hu'a onça ou parte de toda a couza inteyra seu nome particular os quais refere o Emperador Justiniano no $\S$ hæereditas institutis de horedibus instituendis [itálico nosso] ${ }^{59}$ a saber á duodecima parte chamavão onça, a sexta parte que erão duas onças sextans; a tres onças, ou á quarta parte chamavão quadrans; a quatro onças, ou ao terço chamavão triens; a cinco onças ou 5/ 12 chamavão quincunx; á metade, ou 6 onças semis; a 7 onças, ou $7 / 12$ septunx; a 8 onças ou $2 / 3$ bes; a 9 onças, ou $3 / 4$ dodrans; a 10 onças dextans; a 11 onças deunx, e a todo o inteyro, ou 12 onças chamavão ás; e dos sobreditos nomes dirivou Glodman [Goldman] as palavras dodrantais, dimidiatos, e quadrantais ${ }^{60}$.

\footnotetext{
${ }^{8}$ As palavras em grifo no parágrafo são originárias de termos latinos adaptados à nova linguagem das fortificações dos tratados consultados, como Vellozo explica em seguida, principalmente por Nicolau Goldman. Alguns destes tratados de fortificações tiveram as suas versões primeiras em latim que era uma língua mais universal, na época, do que o holandês, por exemplo.

${ }^{59}$ Do Código do Imperador Justiniano.

${ }^{60}$ O sistema de divisão romana para a libra era duodecimal. Eles usavam também as subdivisões da libra para indicar frações de números. Assim sextans tanto significava 2 onças (uncia), quanto a fração $\mathbf{1 / 6}$, quadrans a fração $1 / 4$, triens a fração $1 / 3$ e assim por diante. O que não fica explicado é a origem do termo dimidiato, porque este não representa uma subdivisão ou fração da libra, que no caso da metade era chamado de semis, como o próprio Vellozo refere. Neste particular a palavra empregada vem de outro vocábulo latino dimidiatio-onis, que significa dividir ao meio e vem do verbo dimidiare.
} 
Adam Fritach as dividio em tres sortes, a saber em real grande quando a linha da defença fechante he de 60 vergas, ou proximamente, suppondo que tanto he o tiro de mosquete de ponto em branco, e segundo este fundamento diz se costumão cercar as grandes praças por evitar as despezas de muytos baluartes, assentando que esta he a mayor distancia a que se devem situar: em meãa [sic] real quando a linha da defença não chega a 60 vergas; que são 720 pés $[237,6 \mathrm{~m}]$, mas o lado do poligono exterior passa das ditas 60 vergas ou 720 pés; em pequena real quando o dito lado exterior he de 60 vergas, o qual lado diz elle que serve so para cercar as pequenas villas, como tambem para fortificações irregulares, e que p. ${ }^{a}$ fortificar hu'a cidade grande não he tanto a propozito em razão dos muytos baluartes que serião necessarios.

O Conde de Pagan seguio a mesma divizão, e conforme a ella descreveo tres sortes de fortificações reais, a saber grande, meãa [sic], e pequena; na primeyra faz o lado do poligono exterior de 200 toezas, ou 1200 pés [396m]; na segunda de 180 toezas, ou 1080 pés $[356,4 \mathrm{~m}]$, e na $3^{\text {a }} 160$ toezas, ou 960 pés $[316,8 \mathrm{~m}]^{61}$.

Monsieur Blondel suppoem que a linha da defença nas praças reais não deve passar de 140 toezas, nem ser menor de 120; e por tanto diz que o lado exterior não excederá de 200 toezas, nem baixará de 170 que são 1020 pés [336,6m].

\footnotetext{
${ }^{61}$ Vellozo está citando Pagan, autor francês que usva muito a toeza como medida. Não fica, porém, muito claro se os pés e toezas a que ele se refere são portugueses, porque não especifica. Em princípio, parece-nos que se trata de pé português e a toesa também porque corresponde exatamente a 6 pés de $0,33 \mathrm{~m}$ (valor do pé português), o que nos dá um total de 1,98m como encontramos em alguns formulários antigos e não de $1,94 \mathrm{~m}$ como se calcula na "taboada" de conversões de Serrão Pimentel. Isto, porém, é perfeitamente explicável em virtude de não haver um sistema métrico padrão e cada local adotar sistemas de medidas variáveis que também poderiam variar com o tempo. Assim, sendo o texto de Serrão do Século XVII e o de Vellozo do Século XVIII, pode explicar a diferença.
} 
Nos posto [sic] que no quadrado nos podiamos estender athe 1080 pés $[356,4 \mathrm{~m}]$, ou athe $1148[378,84 \mathrm{~m}]$ conforme puzermos a fechante de $800[264 \mathrm{~m}]$, ou de $850[280,5 \mathrm{~m}]$ pello que dissemos no $\mathrm{Cap}^{\circ}$ 12, com tudo como o quadrado he figura menos commoda para hu'a grande fortificação, e nas mais figuras say a dita fechante crescendo alguma couza supposto o mesmo lado exterior para pormos neste hum termo certo em todas diremos se não estenda mais que athe 1000 pés [330m], ou quando muyto athe 1050 [346,5m].

Mas o menor lado exterior não será menos de 225 pés [74,25] porque assim rezultará a cortina ao menos de 100 pés [33m], ultimo termo menor conforme o Cap ${ }^{0} 13$. Se for mais dos ditos 225 será melhor, e tanto mais tanto melhor athe 1000 [330m], ou 1050 [346,5m] o mais.

Acerca do lado do poligono interior, não pode bem servir hum mesmo numero para todas as figuras, será por tanto o mayor lado interior.

\begin{tabular}{|c|c|c|c|c|c|}
\hline No Quadrado & ${ }_{-}:$ & 703 & - ${ }_{-}$ & athe & ${ }_{-}:$ \\
\hline No Pentagono & ${ }_{-}:_{-}(x)+$ & 750 & _: & athe & _: \\
\hline No Exagono & ${ }_{-}{ }_{-}$ & 763 & - : & athe & ${ }_{-}:$ \\
\hline No Eptagono & $-:$ & 770 & $-:_{-}$ & athe & _: \\
\hline No Octogono & $-:$ & 795 & ${ }_{-}:_{-} \quad r$ & athe & $-:$ \\
\hline No Eneagono & $-:$ & 805 & ${ }_{-}:$ & athe & _: \\
\hline No Decagono & $-:$ & 820 & $-:_{-} \quad r$ & athe & _: : r l \\
\hline No Undecagono & $-:$ & 834 & $-{ }_{-}$ & athe & _: \\
\hline No Duodecagono & $-:$ & 845 & ${ }_{-}{ }_{-}$ & athe & _: : $\quad$ r \\
\hline Ja fig. ${ }^{a}$ de 18 lados & $-:$ & 880 & $-:$ & athe & _ : \\
\hline Ja linha recta & (8 & 1000 & & athe & _- \\
\hline
\end{tabular}


Conforme tomarmos a fechante de 800 pés [264m] athe 850 [280,5m], e conforme as proporções da taboada numero $2^{\circ}$ o que succederá com pouca differença tambem nas proporções das outras taboadas numero $3^{\circ}$ e $4^{\circ}$.

O menor lado interior nos fortes quadrados e pentagonicos onde póde ser necessario restringir aos minimos termos, nunca será tão pequeno que a cortina rezulte menor de 100 pés [33m], a saber, no quadrado nunca será menor de 150 [49,5m], no pentagono de 160 [52,8m], e nas mais figuras irregulares a esse respeyto.

Porem póde vir em duvida qual he melhor para se fortificar se hu'a figura de mais lados, ou outra de menos mas mayores sendo ambas do mesmo perimetro, a saber, qual fortificação he melhor se a de hum exagono de 500 pés $[165 \mathrm{~m}$ ] por exemplo em cada lado cuja somma de todos seis fazem 3000 [990m]; ou a de hum pentagono de 600 [198m], cuja somma de todos cinco fazem os mesmos 3000 .

Por parte da figura de mais lados se póde alegar que he mais, capaz, e assim com igual ambito inclue mais espáço, a que se deve attender por respeyto dos alojamentos que he necessario fazer dentro das fortalezas: em segundo lugar que offerecem melhor commodidade para se fortificarem por respeyto que sendo mayor o seu angulo da circumferencia rezulta mayor o flanqueado do baluarte, e por tanto mais forte, o que sempre se deve procurar: em terceyro lugar que quantos mais baluartes tiver a figura, ou praça fortificada, tanta mais força terá, por serem os baluartes na fortificação os córpos defendentes.

Sem embargo destas razões eu elegera antes a figura de mayores lados, e a razão em que me fundo he porque conforme 
a grandeza dos lados rezultão mayores os flancos, mayores e mais capazes os baluartes, o que he mais conforme as maximas da boa fortificação, e para mayor clareza da rezolução será bom saber de que grandeza fica cada hum dos baluartes nas duas figuras propostas, por exemplo no exagono regular de 500 pés [165m] de lado exterior (conforme as proporções da nossa $1^{a}$ taboada) será o flanco primario de 62 pés e $1 / 2$ [20,62m]; e no pentagono de 600 pés [198m] será de 66 pés e $3 / 5$ [21,97m] mayor por 4 pes e $1 / 10$ de pê [1,35m]; a area do baluarte no exagono será de 17040 e 16/100 [1855,66m²], no pentagono será de 25510 e 57/100 [2.778,10m²] mayor por 8470 e 41/100 [922,42 $\left.\mathrm{m}^{2}\right]$ pello que claramente se ve que no pentagono não só o baluarte, mas tambem os flancos serão mayores, e mais capazes, e por tanto melhores.

Verdade he que a area que inclue a fortificação do sobredito pentagono he so 305950 pés [33.317,95 $\left.\mathrm{m}^{2}\right]$ quadrados, porem a area que inclue o exagono he 341263 pés e $7 / 10$ de pê [37.163,61 $\left.\mathrm{m}^{2}\right]$, mayor por 35313 pés e $7 / 10$ [3.845,66m²] de pê o que confirma a primeyra razão contraria da mayor capacidade para os alojamentos necessarios dentro nas fortalezas; mas a isto se responde que a questão he sobre qual das fortificações tem melhores defenças, e não qual offerece mayor capacidade e commodo para a habitação; e posto que tambem a isto se deve attender, isso será quando a defença for igual, mas sendo mayor primeyro se deve haver respeyto á defença do que á capacidade da praça.

Semelhantemente se responde a segunda razão contraria a saber que a mayor commodidade que offerece a figura de mais lados para se fortificar vem so a topar na mayoria dos angulos flanqueados cuja conveniencia (pello que se discorreo no Cap ${ }^{\circ}$ 17) he menor que a mayoria dos flancos que se segue dos mayores 
lados, ainda quando a dita mayoria dos angulos tiver algu'a entidade que não tem, poys tanto q' os ditos angulos passão de 70 graos, e dahi para sima são igualmente bons, não se podendo atribuir ventagem de concideração a hum angulo por exemplo de 75 graos sobre o de 72 , e muyto menos a hum de 85 sobre o de 80 conforme o dito no $\mathrm{Cap}^{\circ} 17$.

No que toca á terceyra razão de que sendo mais os baluartes ha mais corpos defendentes, e assim fica a fortificação com mais força, isso he quando os baluartes são de hu'a mesma grandeza, mas sendo menores, antes fica a fortificação mais fraca por ter corpos mais fracos que defender.

E não he certo absolutamente que hu'a fortificação tem mais força quantos mais baluartes tem porque esta maxima se não deve tomar tão geral como a propoem Dogen liv. $1 .{ }^{\circ}$ Cap $^{\circ} 4$ mas devese limitar athe hum certo numero, como athe 10, ou 12, porque sendo de mais a mesma multidão a fará fraca, pella muyta guarnição de gente, artelheria, e monições de que necessitará, que como hum Principe, ou estado não tem hu'a so praça que prover, devem-se regular os gastos com os cabedays; porque faltando estes, não falte o espirito q' deve animar a fortaleza, a qual tanto que tiver de seis baluartes para sima ja he capaz de rezistir a qualquer exercito.

Ultimamente não obsta o haverse dito no $\mathrm{Cap}^{\circ} 8^{\circ}$ ser opinião commua [sic] que todos perferem as praças regulares de mais lados ás de menos, porque isso se entende quando ambas tenhão hum mesmo lado, que então he sem duvida ser melhor e mais forte a de mais lados que a de menos athe o termo de 10 ou 12 baluartes, como fica proximamente dito; porem sendo em duas figuras proximas os lados deziguais, será melhor aquella que tiver mayores 
lados; e daqui se segue a razão por onde diziamos asima que quanto o lado exterior em qualquer figura for mayor de 225 pés [74,25m] ultimo termo menor, tanto será melhor, poys a bondade da fortificação pende [depende] mais da grandeza de cada lado da figura, que do grande numero delles.

Porque não haja duvida na grandeza de cada pé de que fallamos, se entenda ser cada hum de palmo e meyo craveyro dos quais tem cinco a vara Portugueza que chamão craveyra, e o covado tres, com o que vem a ser cada pé justamente meyo covado $^{62}$.

\author{
$\operatorname{Cap}^{\circ} 19$. \\ DO VALOR DOS ANGULOS E GRANDEZA \\ DAS LINHAS QUE REZULTÃO DAS PROPORÇÕES \\ EXPLICADAS NOS CAPITULO $80^{\circ} \mathrm{E} 90^{\circ}$
}

A invenção do valor dos angulos e linhas de qualquer figura fortificada dado o modo por onde se fortificou he couza muyto facil a quem tiver noticia da Trigonometria com alguma luz da geometria de Euclides, por tanto porque esta materia esta muyto bem dita no Methodo Luzitanico nos cap ${ }^{\text {os }} 5^{\circ}$ e $6^{\circ}$ da segunda parte julgo escuzado o repetilla; somente (poys havemos dado differentes proporções) proponho as medidas que dellas rezultão, nas tres seguintes taboadas para as quais suppus o mesmo numero que se tomou

\footnotetext{
$\overline{62}$ O palmo craveiro sendo, aproximadamente, $22 \mathrm{~cm}$ atuais, daria para o pé (1 palmo e $1 / 2)$ o valor de $33 \mathrm{~cm}$ e a vara craveira portuguesa, pelo especificado, o valor de 5 pés ou $110 \mathrm{~cm}$ (meia braça). Segundo o autor o côvado tinha o valor de três palmos ou $66 \mathrm{~cm}$.
} 


\begin{tabular}{|c|c|c|c|c|c|c|c|c|c|c|c|}
\hline \multicolumn{12}{|c|}{$\begin{array}{l}\text { Taboada n. }{ }^{\text {ro }} 5 \text { do valor dos angulos, e grandeza das linhas que rezultão das proporções } \\
\text { explicadas no Cap. } 7^{\circ} \text { suppondo o lado do poligono exterior } 864 \text {. }\end{array}$} \\
\hline $\begin{array}{l}\mathrm{N}^{\circ} \text { dos lados das } \\
\text { fig. }{ }^{\text {as }}\end{array}$ & 4 & 5 & 6 & 7 & 8 & 9 & 10 & 11 & 12 & 18 & $\begin{array}{c}\mathrm{L}^{\mathrm{a}} \\
\text { recta }\end{array}$ \\
\hline \multicolumn{12}{|c|}{ Angulos } \\
\hline Da figura & 90 & 108 & 120 & 128.34 & 135 & 140 & 144 & 147.16 & 150 & 160 & 180 \\
\hline Diminuto & 14.2 & 18.26 & 22.14 & 24.13 & 25.20 & 26.33 & 27.53 & 28.36 & 29.22 & 33.41 & 33.41 \\
\hline Flanqueado & 61.56 & 71.8 & 75.32 & 80.8 & 84.20 & 86.34 & 88.14 & 90.4 & 91.16 & & 112.38 \\
\hline Da Espalda & 104.2 & 108.26 & 112.14 & 114.13 & 115.20 & 116.33 & 117.53 & 118.36 & 119.22 & & 123.41 \\
\hline Da tenalha exterior & 151.56 & 143.8 & 135.32 & 131.34 & 129.20 & 126.34 & 124.14 & 122.48 & 121.16 & & 112.38 \\
\hline \multicolumn{12}{|c|}{ Lado exterior 864} \\
\hline Sobreface & 240 & 240 & 240 & 240 & 240 & 240 & 240 & 240 & 240 & 240 & 240 \\
\hline Extenção & 60 & 80 & 98.1 & & 113.6 & 120 & 127 & 130.9 & 135 & & 160 \\
\hline Flanco $\mathrm{r}$ & 90 & 96 & 108 & 123.4 & 127 & 135 & 135 & 135 & 135 & 135 & 135 \\
\hline Flanco prolongado & 150 & 176 & 206.1 & 231.4 & 240.6 & 255 & 262 & 65.9 & 270 & 295 & 295 \\
\hline Face & 247.4 & 252.9 & 259.2 & 263.1 & 265.5 & 268.3 & 271.3 & 73.3 & 275.3 & 288 & 288.4 \\
\hline Extenção da face & 371 & 303.3 & 285.3 & 300.6 & 298.2 & 301.8 & 288.6 & 281.8 & 275.3 & 243 & 243.3 \\
\hline Linha razante & 618.4 & 556.2 & 544.5 & 563.7 & 563.7 & 570.1 & 560.1 & 555.1 & 550.6 & 531.7 & 531.7 \\
\hline Cortina & 384 & 384 & 384 & & 384 & 384 & 38 & 384 & 384 & & 384 \\
\hline $\begin{array}{l}\text { Complem }{ }^{\text {to }} \\
\text { cortina }\end{array}$ & 360 & 288 & 264.2 & 274.2 & 268.3 & 270 & 255.1 & 247.5 & 240 & 202.5 & 202.5 \\
\hline Flanco segundo & 24 & 96 & 119.8 & 109.8 & 115.7 & 114 & 128.9 & 136.5 & 144 & 181.5 & 181.5 \\
\hline Lado interior & 564 & 608.4 & 626 & 641.2 & 664.8 & 678.4 & 693.8 & 707.8 & 718.8 & 760 & 864 \\
\hline Demigola & 90 & 112.2 & 121 & 128.6 & 140.4 & 147.2 & 154 & 161.9 & 167.4 & 18 & 240 \\
\hline Semidiam. Mayor & 610 & 735 & 86 & 993.8 & 1128.7 & 1263 & 139 & 1533 & 1669 & 24 & 0000 \\
\hline Capital & 212.1 & 217.5 & 238 & 256.8 & 260.4 & 271.3 & 275.4 & 277.1 & 279.5 & 299.5 & 299.5 \\
\hline Semidiam. Menor & 397.9 & 517.5 & 626 & 739 & 868.3 & 991.7 & 1122.6 & 1255.9 & 1389.5 & 2188.5 & 0000 \\
\hline Linha fechante & 641.7 & 648.3 & 656.3 & 665.5 & 668.7 & 674 & 676.7 & 678.6 & 680.2 & 690.2 & 690.2 \\
\hline Gola & 127.2 & 181.5 & 209.6 & 231.7 & 249 & 276.6 & 294.6 & 310.6 & 323.4 & 365 & 480 \\
\hline
\end{tabular}

Taboada $n .{ }^{\text {ro }} 6$ do valor dos angulos, e grandeza das linhas que rezultão das proporções explicadas no Cap. ${ }^{\circ} 8{ }^{\circ}$ para fortificar do lado do polig ${ }^{\circ}$ interior p. $^{\text {a }}$ fora.

\begin{tabular}{|c|c|c|c|c|c|c|c|c|c|c|c|c|}
\hline N..$^{\circ}$ dos lados & 4 & & & & & & & & & & & \\
\hline das fig. ${ }^{\text {as }}$ & 4 & 5 & 6 & 7 & 8 & 9 & 10 & 11 & 12 & 18 & 36 & L"recta \\
\hline & & & & & & igulos. & & & & & & \\
\hline $\begin{array}{ll}\text { Ang }^{\circ} & \text { da } \\
\text { figura } & \\
\end{array}$ & 90 & 108 & 120 & 128.34 & 135 & 140 & 144 & 147.16 & 150 & 160 & 170 & 180 \\
\hline $\begin{array}{l}\text { Ang }^{\circ} \\
\text { diminuto }\end{array}$ & 14.2 & 18.26 & 22.7 & 24.10 & 25.24 & 26.41 & 27.44 & 28.36 & 29.36 & 33.45 & 33.45 & 33.45 \\
\hline $\begin{array}{l}\mathrm{Ang}^{\mathrm{O}} \\
\text { flanqueado }\end{array}$ & 61.56 & 71.8 & 75.46 & 80.14 & 84.12 & 86.39 & 88.32 & 90.4 & 90.48 & 92.38 & 112.30 & 112.30 \\
\hline $\begin{array}{ll}\text { Ang }^{\circ} & \text { da } \\
\text { espalda } & \\
\end{array}$ & 104.2 & 108.26 & 112.7 & 114.10 & 113.24 & 116.41 & 117.44 & 118.36 & 119.36 & 123.45 & 123.45 & 123.45 \\
\hline $\begin{array}{ll}\text { Ang }^{\circ} & \mathrm{da} \\
\text { tenalha } & \\
\text { exterior } & \\
\end{array}$ & 151.56 & 143.8 & 133.46 & 131.40 & 129.12 & 126.38 & 124.32 & 122.48 & 120.48 & 112.30 & 112.30 & 112.30 \\
\hline & & & & & mprim & nto das 1 & nhas. & & & & & \\
\hline Lado interior & 564 & 608 & 626 & 641 & 664 & 678 & 693 & 707 & 718 & 760 & 812 & 864 \\
\hline Demigola & 90 & 112 & 121.1 & 128.2 & 139.7 & 147.1 & 154 & 161 & 167.8 & 188 & 213.6 & 240 \\
\hline Flanco recto & 90 & 96 & 107.3 & 123.2 & 127.6 & 135.6 & 135 & 135.9 & 135.8 & 135 & 135.3 & 135 \\
\hline Cortina & 384 & 384 & 383.8 & 384.6 & 384.6 & 383.8 & 385 & 385 & 382.4 & 384 & 384.8 & 384 \\
\hline $\begin{array}{l}\text { Flanco } \\
\text { secundario }\end{array}$ & 24 & 96 & 119.9 & 110.1 & 116 & 113.9 & 128.3 & 136.7 & 143.4 & 182 & 182.3 & 182 \\
\hline $\begin{array}{l}\text { Complem }^{\text {to }} \\
\text { da cortina }\end{array}$ & 360 & 288 & 263.9 & 274.5 & 268.6 & 269.9 & 256.7 & 248.3 & 239 & 202 & 202.5 & 202 \\
\hline Capital & 212.1 & 217.5 & 236 & 255.9 & 261.2 & 272.9 & 273.8 & 277.2 & 282.2 & 299.1 & 296.4 & 295 \\
\hline Face & 247.4 & 252.8 & 258 & 262.1 & 265.2 & 269.3 & 268.8 & 271.7 & 276.9 & 287.7 & 287.9 & 288.6 \\
\hline $\begin{array}{l}\text { Extenção da } \\
\text { face }\end{array}$ & 371 & 303.6 & 285 & 300.9 & 297.5 & 301.8 & 290.8 & 283.9 & 274.9 & 243.4 & 243.5 & 243 \\
\hline Razante & 618.4 & 556.4 & 543 & 563 & 562.7 & 571.1 & 559.6 & 555.6 & 551.8 & 531.1 & 531.4 & 531.6 \\
\hline Sobreface & 240 & 239.8 & 239 & 239.1 & 239.6 & 240.9 & 237.9 & 238.5 & 240.7 & 239.2 & 239.3 & 240 \\
\hline $\begin{array}{l}\text { Extenção do } \\
\text { flanco }\end{array}$ & 60 & 79.9 & 97.1 & 107.3 & 113.7 & 120.9 & 125.1 & 130 & 136.7 & 159.8 & 159.9 & 160.3 \\
\hline $\begin{array}{l}\text { Flanco } \\
\text { prolongado }\end{array}$ & 150 & 175.9 & 204.4 & 230.5 & 241.3 & 256.5 & 260.1 & 265.9 & 272.5 & 294.8 & 295.2 & 295 \\
\hline $\begin{array}{l}\text { Lado } \\
\text { exterior }\end{array}$ & 864 & 863.8 & 861.8 & 862.8 & 863.8 & 865.6 & 860.8 & 862 & 863.8 & 862.8 & 863.4 & 864 \\
\hline $\begin{array}{l}\text { Linha } \\
\text { fexante }\end{array}$ & 641.7 & 648.2 & 655.4 & 664.9 & 669.7 & 675 & 675 & 677.7 & 680.3 & 689.3 & 690.3 & 690.1 \\
\hline
\end{tabular}




\begin{tabular}{|c|c|c|c|c|c|c|c|c|c|c|c|c|}
\hline \multicolumn{13}{|c|}{$\begin{array}{l}\text { Taboada n. }{ }^{\text {ro }} 7 \text { do valor dos angulos, e grandeza das linhas que rezultão das proporções da } \\
\text { taboada n. }{ }^{\text {ro }} 3 \text { explicadas no Cap. }{ }^{\circ} 8{ }^{\circ}{ }^{\text {pa }} . \text { fortificar do lado do polig }{ }^{\circ} \text { interior p. }{ }^{\text {a fora. }} \text { for }\end{array}$} \\
\hline $\begin{array}{l}\text { N. }{ }^{\circ} \text { dos lados } \\
\text { das fig. }\end{array}$ & 4 & 5 & 6 & 7 & 8 & 9 & 10 & 11 & 12 & 18 & 36 & $\mathrm{~L}^{\mathrm{a}}$ recta \\
\hline \multicolumn{13}{|c|}{ Angulos. } \\
\hline \begin{tabular}{ll|} 
Angulo & da \\
fig. & \\
\end{tabular} & 90 & 108 & 120 & 128.34 & 135 & 140 & 144 & 147.16 & 150 & 160 & 170 & 180 \\
\hline $\begin{array}{l}\text { Ang } \\
\text { diminuto }\end{array}$ & 14.1 & 17.46 & 22 & 24.37 & 26.4 & 27.3 & 27.32 & 28.4 & 28.36 & 30,57 & 36.19 & 36.20 \\
\hline $\begin{array}{l}\mathrm{Ang}^{\circ} \\
\text { flanqueado }\end{array}$ & 61.50 & 72.28 & 76 & 79.22 & 82.52 & 85.54 & 88.56 & 91.8 & 92.48 & 98.6 & 97.22 & 107,20 \\
\hline \begin{tabular}{ll|}
$\begin{array}{ll}\text { Ang } \\
\text { espalda }\end{array}$ & da \\
\end{tabular} & 104.5 & 107.16 & 112 & 114.37 & 116.4 & 117.3 & 117.32 & $118 \ldots$ & 119.36 & $120 \ldots$ & 126.19 & 126.20 \\
\hline $\begin{array}{l}\text { Ango } \\
\text { tenalha } \\
\text { exterior }\end{array}$ & 151.50 & 144.28 & 136 & 130.46 & 127.52 & 125.54 & 124.46 & 123.52 & 122.48 & 118.60 & 107.22 & 107.2 \\
\hline \multicolumn{13}{|c|}{ Lado interior 600} \\
\hline Demigola & 96 & 103 & 110 & 115 & 120 & 125 & 125 & 125 & 125 & 133.3 & 135 & 135 \\
\hline Flanco recto & 96 & & 105 & 110 & & 120 & 120 & 120 & 120 & 120 & 125 & 125 \\
\hline Cortina & 408 & 390 & 380 & 370 & & 350 & 350 & 35 & 350 & 333.4 & 330 & 330 \\
\hline $\begin{array}{l}\text { Flanco } \\
\text { secundario }\end{array}$ & 25.5 & 78 & 120 & 120 & 125 & 113 & 120 & 125 & 130 & 133.4 & 160 & 160 \\
\hline $\begin{array}{l}\text { Complem }{ }^{\text {to }} \\
\text { da cortina }\end{array}$ & 382.5 & 312 & 260 & 250 & 235 & 235 & 230 & 225 & 220 & 200 & 170 & 170 \\
\hline Capital & & 5.4 & & 231.6 & & 40.2 & 234.3 & 30 & 228 & 226.9 & 240. & 217 \\
\hline Razante & 658.5 & 570.7 & 520.2 & 501 & 493.6 & 496.5 & 482 & 470.2 & 460.1 & 434.5 & 404.5 & 378.6 \\
\hline $\begin{array}{l}\text { Extenção da } \\
\text { face }\end{array}$ & 394.5 & 327.7 & 280.2 & 264.1 & 261.7 & 263.8 & 249.5 & 255 & 250.6 & 233.3 & 211 & 211 \\
\hline Face & 264 & 243 & 24 & 236.9 & 233.9 & 232.7 & 232.3 & 215.2 & 209.5 & 201.2 & 193.5 & 167.6 \\
\hline Sobreface & 256 & 231.4 & 222.5 & 215.3 & 210.1 & 207.2 & 206.2 & 189.8 & 183.9 & 172.5 & 155.9 & 135 \\
\hline $\begin{array}{l}\text { Extenção do } \\
\text { flanco }\end{array}$ & 64.2 & 174.1 & 194.9 & 190.7 & 217.8 & 225.8 & 227.4 & 221.2 & 220.2 & 223.4 & 239.6 & 224.3 \\
\hline $\begin{array}{l}\text { Flanco } \\
\text { prolongado }\end{array}$ & 160.2 & 174.1 & 194.3 & 190.7 & 217.1 & 225.8 & 227.4 & 221.2 & 220.2 & 223.4 & 239.6 & 224.3 \\
\hline $\begin{array}{l}\text { Lado } \\
\text { exterior }\end{array}$ & 920 & 854.8 & 825 & 790.6 & 780.2 & 764.4 & 762.4 & 729.6 & 717.8 & 678.4 & 641.8 & 600 \\
\hline L. ${ }^{2}$ fichante & 683 & 647.5 & 633.2 & 606 & 610.2 & 601.2 & 600.8 & 583.3 & 577 & 553.1 & 541.7 & 516.2 \\
\hline
\end{tabular}

por exemplo no dito Methodo Luzitanico, a saber para a taboada numero 5 suppus o numero 864 para o lado exterior em todas as figuras para que facilmente se possão logo combinar as medidas da dita taboada com qualquer das tres numero $8^{\circ}, 9^{\circ}$, e $10^{\circ}$ do Methodo Luzitanico.

Na taboada numero 7 propuz o mesmo numero 600 por lado interior em todas as figuras para com a mesma facilidade se combinar com as taboadas numeros 13, e 14 do mesmo Methodo Luzitanico.

$\mathrm{Na}$ taboada porem numero 6 propus differentes lados interiores para se ver como as proporções para fortificar do lado interior para fora propostas na taboada numero 2 concordão proximamente com as da taboada numero $1^{\circ}$ por onde fortificando qualquer 
figura do lado exterior para dentro, se outra vez se fortificar do lado interior que the rezulta para fora, ou pello contrario virá huma e outra fortificação a concordar muy proximamente segundo notamos depoys na dita taboada no $\mathrm{Cap}^{\circ} 9^{\circ}$.

E combinando as ditas taboadas se achará que pellas nossas proporções nas mais das figuras rezultão mayores os flancos, mayores as capitays, e as faces dos baluartes, com que estes ficão com mais capacidade, e assim logrão melhor o que requerem os axiomas da boa fortificação; somente os angulos flanqueados sahem algu'a couza menores, mas nem por isso ficão poyores [sic], poys ja no Cap ${ }^{0} 17$ aprovamos antes o parecer de Maroloes, que acrescenta 15 graos ao semiangulo da figura para de tanto formar o flanqueado, pello qual modo rezulta recto na figura de 12 lados; e como assim rezulta proximamente das nossas proporções não ha para que nos queyrão perferir [preferir] os mais obtuzos.

Pello que em favor das ditas nossas proporções offereço todas as razões que dá o mesmo Methodo Luzitanico na $2^{\mathrm{a}} \mathrm{p}^{\text {te }} \S 6^{\circ} \mathrm{e}$ $7^{\circ}$ combinando-as suas com a doutrina dos mais dos auctores modernos, as quais razões tanto mais favorecem as nossas proporções a respeyto das dos auctores, quanto ellas se fundão em mayores flancos, e assim em mayor defença. 


\author{
$\mathrm{Cap}^{\circ} 20$ \\ DO METHODO PARTICULAR DE ALGUNS \\ AA [AUTORES] MODERNOS PARA FORTIFICAR ASSIM \\ DO LADO EXTERIOR PARA DENTRO, COMO \\ DO INTERIOR PARA FORA.
}

\title{
Methodo de Antonio de Ville
}

Foy este o primeyro dos auctores modernos que com aceytação e aplauzo universal propos o seu methodo, pella summa facilidade de se desenhar na campanha, em todos os poligonos faz o angulo flanqueado recto excepto no quadrado e pentagono, porque a sua pequenhez o não admite sem gravissimos inconvenientes, e sempre fortifica do lado interior para fora na forma seguinte.[:]

Divide o lado por exemplo $\mathrm{AB}$ do poligono em 6 partes, e toma hu'a de cada parte para demigola como $\mathrm{AC}$ e $\mathrm{BD}$, e dos pontos $\mathrm{C}$ e D levanta os flancos perpendiculares, e iguais ás demigolas, e tira a linha transversal LE, e descrevendo sobre ella hum semicirculo, e produzindo a capital esta notará na sua circunferencia o ponto $\mathrm{N}$ onde se deve formar o angulo flanqueado recto pelas faces tiradas dos pontos L e E, que produzidas darão neste exemplo (que suppomos do exagono) e nos mais poligonos o flanco secundario CF o qual hirá crescendo nas figuras de mayor numero de lados.

No quadrado, e no pentagono em que o angulo flanqueado não póde ser recto como ja se disse, não he necessario o methodo de o fazer sobre a transversal, porque para determinar as faces se tira hu'a linha do angulo do flanco e cortina pelo extremo de cada hum dos flancos, as quais linhas se encontrão na capital, ou radio produzido formando o angulo flanqueado agudo. 
Este auctor imitou aos Engenheyros Italianos antigos, e os Francezes o imitarão a elle, aperfeyçoando cada vez mais as offenças e as deffenças.

As mais particularidades deste auctor se dirão adiante quando se tratar do orelhão, ou espalda, e das obras exteriores.

\section{Methodo do Conde Pagan.}

O methodo deste auctor (o qual compôs em oppozição do de Antonio de Ville) admite tres ordens de fortificações a saber grande, mediana, e pequena, dando á grande fortificação 180 braças [396m $]^{63}$ de lado de poligono exterior; á mediana 162 braças [356,4m], e á pequena 144 [316,8m]. Não cuyda da quantidade do angulo flanqueado, nem admite secundario como Ville, nem tão pouco quer o flanco em angulo recto com a cortina, como faz o mesmo Ville, e so o quer perpendicular a razante, porque diz que assim defende melhor a face do baluarte opposto; a forma da sua deligniação he a seguinte: dá 54 braças [118,8m] á face da grande fortificação, 49 e 1/2 [108,9m] á face da mediana, e 45 braças [99m] á pequena: a perpendicular que determina a linha razante he no quadrado da grande fortificação de 24 braças e 3 palmos $[53,46 \mathrm{~m}]$, na mediana, e pequena de 27 braças e 6 palmos [60,79m], e em todos os mais poligonos he sempre de 27 braças [59,47m].

Fig. $24 \quad$ Suppondo poys este Auctor o lado exterior AB de 180 braças [396m] na grande fortificação, de $162[356,4 \mathrm{~m}]$ na mediana, e de 144 [316,8m] na pequena (como fica dito) divide esse lado pelo meyo no ponto $\mathrm{C}$, e levanta a perpendicular $\mathrm{CD}$ de 27 braças $[59,4 \mathrm{~m}]$

\footnotetext{
${ }^{63}$ Estas conversões de braças que se seguem partem do pressuposto de que sejam braças portuguesas de $2,20 \mathrm{~m}$.
} 
em todos os poligonos, excepto no quadrado a que so dá 24 braças e 3 palmos [53,46m] na grande fortificação, e 21 braças e 6 palmos [47,52m] na mediana e pequena: tira pelo ponto $\mathrm{D}$ as linhas da defença ADH, BDG, e toma nellas as faces AE, BF cada hu'a de 54 braças $[118,8 \mathrm{~m}]$ na grande fortificação, de 49 [107,8m] na mediana, e de 45 [99m] na pequena; finalmente lança os flancos EG, FH perpendiculares as linhas da defença razantes BG, AH, e fica determinada a cortina GH.

Tambem diremos adiante quando tratarmos do orelhão e obras exteriores, o que este Auctor dispoem [sic] a cerca de hu'a e outra couza.

Methodo de Monsieur de Vauban

\section{He este Auctor o unico que com razão no prezente seculo} mereceu o universal aplauzo de toda a Europa, e a quem seguem todos os modernos muytos dos quais forão seus decipulos, como forão o cavaleyro de Cambray ${ }^{64}$, o Abbade de Fay ${ }^{65}$, e Monsieur Ozanam, e com ser tão decantado o seu sistema não faltou quem o criticasse, mas com tudo isso não deminuhio o credito deste grande Engenheyro.

Admite este grande Auctor tres ordens de fortificações (como o Conde Pagan) a saber grande mediana, e pequena, e fortifica como elle do lado do poligono exterior para dentro dando 180

\footnotetext{
${ }^{64}$ O Cavaleiro de Cambray foi tratadista francês de fortificação do Século XVII. O mérito do seu trabalho foi mais porque comentou o sistema de Vauban, cujo prestígio era enorme em toda a Europa: Manière de fortifier de M. de Vauban, publicado em Amsterdã, em 1689.

${ }^{65}$ O Abade du Fay, procedeu de maneira muito semelhante ao Cav. De Cambrai comentando e divulgando o método do Marechal Vauban. O seu escrito intitula-se: Manière de fortifier selon la méthode de M. de Vauban, editado em Paris em 1691.
} 
braças [396m] ao dito lado na fortificação grande, 162 [356,4m] na mediana, e 144 [316,8m] na pequena, mas prefere a media as outras duas, e assim o praticão todos os que o seguem; a sua deligniação he na forma seguinte.[:]

Divide o lado $\mathrm{AB}$ pelo meyo no ponto $\mathrm{C}$, e deste ponto levanta a perpendicular $\mathrm{CF}$ igual a outava parte do lado $\mathrm{AB}$ no quadrado; á setima parte no pentagono; e a sexta parte no exagono, e em todos os mais poligonos: pelo ponto $\mathrm{F}$ dos extremos do lado $\mathrm{AB}$ tira as linhas AFH, BFG, que são as linhas da defença terminadas nos pontos $\mathrm{G}$ e $\mathrm{H}$. Para determinar as faces divide o mesmo lado $\mathrm{AB}$ em sete partes iguais, isto em todos os poligonos, e toma duas de $\mathrm{A}$ athe $\mathrm{I}$, e de $\mathrm{B}$ athe $\mathrm{K}$, e nas mesmas linhas da defença toma KG e IH cada huma igual á distancia dos angulos da espalda K, I, e fica determinada a cortina GH, e lançando as linhas KH, IG ficão formados os flancos, e feyta a deligniação de hum lado, e da mesma sorte obra em todos os mais do poligono, athe concluhir a linha fundamental de todo o seu recinto.

Do orelhão, fosso, e obras exteriores que este Auctor pratica diremos adiante.

Não satisfeyto com esta forma de fortificar do lado do poligono exterior para dentro propos outro para fortificar do lado do poligono interior para fora a que deu o nome de novo systema, e he na Fig. ${ }^{a}$ 26 Est.13 forma seguinte: Suppoem o lado AA de 108 braças [237,6m] das [12] quais toma 5 e quatro palmos $[11,88 \mathrm{~m}]$ para cada huma das demigolas $\mathrm{AB}$; levanta os flancos perpendiculares á cortina, e iguais ás demigolas como $\mathrm{BD}$; e para determinar o angulo flanqueado lança (como Antonio de Ville) a transversal DD, que divide pello meyo no ponto I, e toma na capital a distancia IE igual com DI, 
e lançando as linhas ED ficão formadas as faces, e o angulo flanqueado recto.

Para formar os baluartes destacados que ficão servindo de contraguardas ${ }^{66}$, ou meyas luas á torre abaluartada que fica descripta; sobre a capital AO produzida de E para K toma 35 braças e 1 palmo, e desse ponto $\mathrm{K}$ lança as linhas $\mathrm{KB}$ aos angulos do flanco, e sobre estas linhas de K para G toma 50 braças e 4 palmos $[110,88 \mathrm{~m}]$ para comprimento das faces.

Para os flancos lança linhas de $\mathrm{G}$ para $\mathrm{C}$ que he o ponto nas cortinas em que se termina a razante da torre abaluartada, e o comprimento desses flancos determina no ponto $\mathrm{F}$ aonde se encontrão as linhas da defença GB, com GC.

Para deligniar o fosso da torre abaluartada se toma entre as pontas do compasso o comprimento do flanco $\mathrm{BD}$ da mesma torre, e pondo hu'a ponta do compasso no angulo flanqueado E, com outra ponta se descreve o arco $\mathrm{P}$, do extremo do qual se lancem as linhas MF as quais determinarão a largura do fosso.

Para deligniar a tenalha diante da cortina depoys de deyxar hum fosso entre ella, e o flanco do baluarte destacado largo 18 palmos $[3,96 \mathrm{~m}]$ se tomão na linha da defença por diante desse fosso de $\mathrm{H}$ athe $\mathrm{L} 21$ braças e 6 palmos [47,52m] para faces da tenalha, e logo dos pontos LL se lança a cortina que será de 9 braças [19,8m], cortada pello meyo por hum fosso EE tão largo como o do flanco: o fosso entre esta tenalha, e a cortina da praça se faz lançando a linha da contraescarpa $^{67}$ pellos pontos FF que será parallela a cortina.

\footnotetext{
${ }^{66}$ Azevedo Fortes define este elemento de defesa da maneira seguinte: [...] quando as meias luas se estendem a cobrir as faces dos baluartes se chamam de contraguardas ou concervas [...]. Grossomodo podemos dizer que são variantes do revelim com função de proteger o baluarte.

${ }^{67}$ Talude do fosso da fortificação do lado da estrada encoberta.
} 
Para o grande fosso das contraguardas ou baluartes destacados, se produzem as faces diante dos angulos flanqueados, e sobre ellas produzidas de $\mathrm{K}$ para $\mathrm{N}$, se tomão 10 braças e 8 palmos [23,76m], e pelos pontos NN se lanção as linhas aos angulos da espalda G que determinarão a largura do fosso, e estas linhas se devem fazer redondas defronte do angulo flanqueado com a mesma distancia KN de 10 braças, e 8 palmos [23,76m].

Forma tambem defronte da cortina hum grande revelim para o qual levanta do ponto $\mathrm{Z}$ meyo da cortina hu'a perpendicular, e nella signala 64 braças e 7 palmos [142,34m] athe o ponto Q, e deste ponto tira as faces dos pontos VV, a 9 braças $[19,8 \mathrm{~m}]$ dos angulos da espalda $\mathrm{G}$.

As demigolas deste revelim ficão formadas pela linha da contraescarpa do fosso grande, e o fosso deste revelim se faz largo 9 braças $[19,8 \mathrm{~m}]$ e parallelo as suas faces.

Dentro deste revelim faz o dito Monsieur de Vauban outro revelim mais pequeno, tomando sobre as demigolas do grande 12 braças e 6 palmos $[27,72 \mathrm{~m}]$ do ponto 3 athe 2 , e toma 16 braças e 2 palmos $[35,64 \mathrm{~m}]$ de 3 athe 4 na linha capital, e lançando as linhas de 4 athe 2 ficarão formadas as faces do pequeno revelim, e lhe faz hum fosso parallelo largo 4 braças e meya [9,9m].

Sendo o fosso grande aquatico, e neste cazo na gola do pequeno revelim se faz hu'a caldeyra para ter cubertos os barcos que levão os soldados as obras exteriores, e se faz a tal caldeyra tomando quatro braças e meya $[9,9 \mathrm{~m}]$ sobre as demigolas do ponto 3 athe 1, e outro tanto de 3 athe 5 , e se cortão neste ponto por hu'a linha parallela á cortina; sobre esta linha se tomão 12 palmos [2,64m] de 5 para 7 , e se lanção as linhas 1,7 , e fica formada a caldeyra. 
Para fazer a estrada encuberta se lanção linhas parallelas á contraescarpa em largura de quatro braças e meya, e a donde estas linhas fazem angulos reintrantes se formão as praças de armas a roda da meya lua, ou outras obras exteriores (se as ha) tomando do ponto donde se encontrão as linhas de cada parte 9 braças $[19,8 \mathrm{~m}]$ de 8 athe $\mathrm{X}$, e logo com o compasso dos pontos X e X com a abertura de 11 braças e 7 palmos [25,74m] se fará hu'a secção no ponto $\mathrm{Y}$, e ficará formado o angulo saliente em lugar do reintrante.

Nestes angulos salientes costuma fazer huns caminhos cubertos, ou tambem hum atalho aberto que servem para as sortidas, e para se fazerem fornilhos na esplanada, e a sua largura he de 15 palmos $[3,30 \mathrm{~m}]$.

Os travezes se praticão neste methodo sobre a estrada encuberta, para não ser enfiada da campanha, groços 27 palmos [5,94m], e são perpendiculares a contraescarpa, deyxando junto ao parapeyto hum espaço de 6 palmos para passagem dos defensores; e para que se não enfiem os que estão no parapeyto deffendendo a explanada, se faz outro pequeno travez, quanto baste para cobrir o espaço primeyro, e afastado do primeyro travez 6 palmos $[1,32 \mathrm{~m}]$.

Monsieur de Vauban não o praticava assim, mas entrava com os seus travezes em parte do parapeyto fazendo nelle hum avanço de 6 palmos [1,32m], como se ve na prezente figura; mas o modo apontado parece melhor.

Este he todo o methodo do novo e grande systema deste grande Autor, mas a sua mesma grandeza o faz muy defficil de executar, porque pende [depende] de huma extraordinaria despeza, cauza porque athe o prezente se não sabe haja praça nenhu'a na Europa, nem fora della que seja fortificada por este methodo. 
Outros muytos de diversos AA [autores] puderamos aqui apontar, mas estes só nos parecem os que bastão para o nosso intento: quem quizer ver mais consulte ao nosso Methodo Luzitanico, ao Engenheyro Portuguez e a Pfeffinger ${ }^{68}$, onde achará muytos Francezes, Espanhoes, Italianos, e Holandezes.

Tem-se athe aqui ensinado o modo de fortificar assim do lado do poligono exterior para dentro, como do interior para fora toda a sorte de praças assim regulares como irregulares, e temos dito tudo o que nos pareceu conveniente acerca das linhas, e angulos que as formão; resta dizermos agora das obras exteriores e fosso que se costumão fazer á roda dessas praças, e como os fossos he a primeyra e principal couza que se faz para retardar o inimigo a que não chegue á muralha, por estes principiaremos a discorrer.

$\operatorname{Cap}^{\circ} 21 .^{\circ}$

DOS FOSSOS.

São os fossos ou a principal, ou hu'a das principays defenças da praça fortificada, de tal modo que diz Pedro Sardi ${ }^{69}$ na Corona tratado $1^{\circ}$ liv. $4^{\circ}$ que nenhuma fortaleza ainda que no resto seja perfeytamente formada póde ter tal nome, nem chamarse

\footnotetext{
${ }^{68}$ O tratado de Engenharia Militar de Pfeffinger foi muito estimado pelos portugueses e teve a sua versão para esta língua com o nome de Fortificaçam moderna ou recopilaçam de differentes methodos de fortificar de que se usão na Europa os espanhoes, francezes, italianose hollandezes. Foi editada em 1713 pel Officina Real Deslandesiana.

${ }^{69}$ Pietro Sardi (1560-após 1642), romano de nascimento, produziu uma série de importantes escritos da arte de fortificar. Segundo alguns autores, é um dos mais legítimos representantes da Escola Italiana. Entre os seus trabalhos, podemos citar: Corona imperiale dell'architettura militare divisa in due trattati, editado em Veneza em 1618, Corno dogale dell'architettura militare, editado na mesma cidade em 1639, Discorso sulla necessità dell'architettura militare, também editado em Veneza em 1642 e outros. Muito referido na tratadística de fortificações, inclusive, na portuguesa.
} 
sitio posto em defença se lhe faltar o fosso: o Conde de Pagan poem o fosso por huma das quatro couzas principays em que consiste a defença de huma praça, que são gente, reparos, artelheria, e fossos.

Fazem-se pelas razões seguintes;[:] a primeyra para impedir ao inimigo que não chegue á praça, ou sua muralhas sem vencer aquelle impedimento.

A segunda para que as muralha fiquem mais altas sem as elevar muyto sobre o livel ${ }^{70}$ da campanha.

A terceyra para que havendo o inimigo desmantelado as defenças altas da praça, não possa passar o fosso sem vencer novos obstaculos nas defenças que dentro nelle se fazem.

A quarta para que mediante o fosso haja melhor dispozição para as sortidas, e para receber os socorros, poys assim humas, como outros se não fazem somente pelas pontes mas muytas vezes convem mais que seja sahindo, ou entrando pelos fossos, para assim se fazerem mais secreta, e occultamente.

A quinta, porque a materia da roina feyta pela bateria inimiga não cauze tão facil subida, poys quanto o plano em que aquella cahe he mais proximo á brecha, tanto menos quantidade he necessaria para se dispor a sobida, e a pofundidade do fosso faz que aquelle plano fique mais remoto da brecha, poys impede que se possa descobrir livremente toda a altura da muralha.

A sexta porque não havendo fosso descobre o inimigo toda a muralha, e por tanto póde fazer a bateria na parte mais inferior, ficando pela roina mais facil a sobida.

A setima, muyto principal, por difficultar o progresso das minas, poys pela profundidade do fosso necessita o inimigo de decer

\footnotetext{
${ }^{70}$ Forma antiga do termo atual nível, mais ligada à raíz latina que deu origem à palavra $e$ que é conservada em muitas línguas como no inglês level ou no italiano livello.
} 
mais abayxo com mayor trabalho e dilação, e isto tanto mais quanto o fosso for mais profundo.

Ultimamente he percizo [sic] fazerse o fosso para haver terra para a fabrica do reparo, porque o havella de conduzir de longe faria hum dispendio excessivo.

\author{
$\operatorname{Cap.~}^{\circ} 22 .^{\circ}$
}

\title{
SE A CONTRA-ESCARPA ${ }^{71}$ SERÁ MELHOR PARALLELA OU OBLIQUA AS FACES DOS BALUARTES.
}

São varias as figuras que diversos AA [autores] aplicarão a formatura do fosso, entre os quais pervaleceo [sic], e he a mais seguida aquella em que a contra-escarpa corre parallela ás faces dos baluartes, vindose a cruzar defronte do meyo da cortina, nas praças regulares: porem como este modo não esteja livre de hum grande inconveniente nas praças honde ha flanco secundario, e he que o angulo reintrante da contra-escarpa vem a tirar a vista do flanco primario todo ou quazi todo principalmente nas praças de muytos baluartes, e na linha recta, de modo que não se descortina do flanco primario o angulo da dita contra-escarpa fronteyro a o angulo do baluarte opposto, todo o lanço da dita contra-escarpa desde aquelle angulo athe o fronteyro do meyo da cortina; porque

Fig. ${ }^{a} 27$ Est.12 seja por exemplo a figura 27 que he a planta da nossa praça de [13]

Olivença a qual he fortificada ao modo Holandez ${ }^{72}$; com grandes

\footnotetext{
${ }^{71}$ Talude que limita o fosso do lado da estrada coberta em oposição à escarpa que é o talude do fosso do lado da fortaleza.

${ }^{72}$ Como apontado, a escola holandesa de fortificar tem grande influência em Portugal, não somente porque Serrão Pimentel lovou-se muito nesta prestigiosa escola de castramentação, mas também pela expressiva influência que o jesuíta holandês Cosmander deixou quando fortificou algumas praças portuguesas.
} 
flancos secundarios na cortina; lancese a contra-escarpa XK parallela ás faces dos baluartes, e distante dellas 100 pés [33m], que he bastantissima largura; vesse poys que de todo o flanco $\mathrm{AB}$ se não póde descobrir a dita contra-escarpa XK, porquanto produzida vem a topar com a cortina, e assim fica o fosso privado de todo o dito flanco primario, e ainda de algu'a parte do secundario, e se isto não he sempre, ao menos he em alguns lanços, porque lhe faz impedimento o angulo reintrante $\mathrm{X}$; nem isto procede por respeyto da irregularidade da planta, mas o mesmo ha de suceder em qualquer figura regular fortificada com flancos secundarios, e tanto mais quanto as figuras forem de mayor numero de lados, pelo que foy necessario buscar algum remedio a este inconveniente.

Alguns cortão o angulo da contra-escarpa formado defronte do meyo da cortina com a linha recta OR, ficando ali mais largo o fosso, como se ve entre os baluartes $\mathrm{n}^{\text {ro }} 2$ e $\mathrm{n}^{\text {ro }} 3$; porem se as linhas $\mathrm{KO}$, KR produzidas imaginariamente não toparem com os flancos, sempre ficará a contra-escarpa defraudada da defença que delles se the podia fazer, com que o gasto de cortar o triangulo OXR se fará sem proveyto, e ficará diminuindo a praça do revelim que se deve fazer naquelle lugar, como adiante se dirá.

O melhor remedio para livrar do inconveniente sobredito foy fazer os fossos mais largos da parte do angulo da espalda, e mais estreytos junto do angulo flanqueado, e a isto he que chamamos fossos obliquos, por não serem parallelos as faces dos baluartes; descreversehão por qualquer dos modos que ensina o Methodo Luzitanico Cap ${ }^{0} 16$ parte $1^{\text {a }}$, e seu scholio; ou tambem pelo modo seguinte que he mais dezembaraçado para se executar na campanha.[:] Produzãose as faces dos baluartes outro tanto cada hu'a como o seu flanco proximo, não sendo este mayor de 100 pés [33m]: 
em cada hum dos ditos flancos se tomem 80 pés [26,4m] contados do angulo flanqueante para o da espalda, ou de $\mathrm{R}$ para $\mathrm{T}$, e logo lançando as linhas TZ formarão estas a contra-escarpa, e ficará descripto como se ve na figura entre os baluartes $\mathrm{n}^{\text {ro }} 8$, 7 , e 6 ; defronte dos angulos flanqueados se lhe fará a redondeza ZY descripta do mesmo angulo flanqueado como de centro, com a distancia XZ, ou XY se estas forem iguais, e se o não forem, lancese a linha ZY, e sobre ella se descreva hum triangulo equilatero, e no angulo opposto a dita linha ZY será o centro do qual se descreverá a dita redondeza; a qual se faz porque o fosso fique assim mais fermozo, e por não estender tanto aquella ponta sem necessidade, e porque fique mais capaz a praça de fora havendo aquella redondeza.

E não obsta poder dizerse contra esta forma de fossos, que por ser mais estreyto junto do angulo flanqueado, elegera o inimigo aquella parte para o cegar, ou passar com galaria ficandolhe mais facil pela estreyteza do lugar, quando se deve procurar por todos os meyos deter o inimigo quanto possa ser apartado do corpo da praça; porque a isto se responde, que ainda que naquella parte seja o fosso mais estreyto, com tudo fica de bastante largura, e muyto mais defendido, poys fica descuberto de muyto mayor porção do flanco, com que a mayor estreyteza se recompensa com a multiplicada deffença que se lhe fica fazendo com mayor numero de tiros.

O que assim supposto respondendo a questão proposta no titulo deste Cap. ${ }^{\circ}$ digo que os fossos obliquos ás faces dos baluartes, mais estreytos junto do angulo flanqueado são melhores que os parallelos nas praças fortificadas com flancos secundarios na cortina porque os obliquos ficão defendidos de todo, ou da mayor parte do flanco primario; porem nas praças fortificadas ao modo 
Frances sem flancos na cortina he melhor o fosso parallelo, porque nestas praças não succede o inconveniente que nas outras foy necessario remediar.

\author{
$\operatorname{Cap}^{\circ} 23 .^{\circ}$ \\ PROPOEM-SE OUTRAS QUESTÕES \\ PERTENCENTES AOS FOSSOS.
}

\begin{abstract}
Questão $1 .^{\mathrm{a}}$
Se he melhor o fosso mais largo e menos fundo, ou mais fundo menos largo.
\end{abstract}

Bonajuto Lorine ${ }^{73}$ liv. $1^{0}$ jornada $5^{\mathrm{a}}$ pertende provar que he melhor o fosso mais largo ainda que menos fundo, tomando por unico fundamento que assim he necessario ao inimigo cegar muyto mayor parte a repeyto da largura, do que se fora mais estreyto; ou que the he necessario fazer mayor caminho com a galaria [sic], de que se the occaziona mayor dificuldade, e perda de gente: e posto que o fosso largo faça com que o inimigo descubra mayor parte da muralha, e por tanto escuze de levantar suas baterias a tanta altura para descobrir a raiz da muralha ou a parte que lhe convier quanto the seria necessario se o fosso fosse mais estreyto, com tudo he mayor o commodo em evitar os inconvenientes sobreditos, que em evitar este, poys na passagem do fosso lhe recrece muyto

\footnotetext{
${ }^{73}$ Buonaiuto Lorini (c.1540-c.1611), pertencia à aristocracia florentina, começando a sua carreira militar com Cosimo de Medici. Serviu quatro anos no exército católico de Flandres; trabalhou na fortificação de Antuérpia; foi engenheiro militar da República de Veneza; operou em fortificações na Dalmácia, Zara, Legnano, Brescia e Bérgamo; trabalhou com Savorgnano nos planos de Palmanova e, durante algum tempo, supervisionou a sua construção. Seu texto mais conhecido é Delle fortificationi libri cinque, também muito citado por Serrão Pimentel.
} 
mais obra, e perigo do que no levantar hum pouco mais as baterias, poys demonstra que lhe basta levantar mais as baterias hum pe e $5 / 6$ de pe $[0,403 \mathrm{~m}]$ a troco de poupar 55 pes $[12,1 \mathrm{~m}]$ de passagem, e esta he toda a força da razão deste auctor pella qual aprova antes os fossos mais largos e menos fundos, do que mais fundos e menos largos.

A esta razão ajunta Dogen liv. $2^{\circ}$ Cap. 10 outras, a saber a primeyra, que sendo o fosso bem largo dá muyta terra para a fabrica das obras.

A segunda, que aparta mais da praça ao inimigo, e suas baterias, porque quanto mais largo he o fosso, tanto mais distante fica da muralha o parapeyto da estrada encuberta donde se abriga a o inimigo a alojarse mais distante, e por cauza da largura do fosso ficarão suas baterias mais longe das muralhas.

A terceyra que he mais capaz, e por tanto de mais comodidade para nelle se fazerem obras repugnatorias ${ }^{74}$, hu'as mais promovidas, e outras mais retiradas socecivamente [sic] contra as do inimigo depoys de haver dezembocado o fosso.

Pello contrario aos fossos muyto largos se oppoem primeyramente que as praças ficão mais descubertas, e por tanto poderá o inimigo mais facilmente embocar e arroinar suas canhoneyras privando a praça desta defença: e a razão he, porque como as pessoas hão de descobrir para bem hu'a athe a ponta do baluarte, outra athe o angulo da contraescarpa, outra athe o ang. ${ }^{\circ}$ reintrante defronte do meyo da cortina, se o fosso for muyto largo he força que as canhoneyras da praça bayxa ${ }^{75}$ sejão muyto abertas

\footnotetext{
${ }^{74}$ Obras destinadas a impedir o avanço do inimigo.

${ }^{75}$ Local abaixo do plano superior do baluarte destinado à operação de bocas de fogo que podem bater os fossos se ocupados pelo inimigo.
} 
nas bocas exteriores para poderem alcançar aquelles pontos, e assim serão faceis de embocar, e mais faceys de arruinar com a artelheria inim. ${ }^{\mathrm{a}}$.

Em segundo lugar, que quando o fosso he $\mathrm{m}^{\text {to }}$ largo chegando o inimigo com seus aproxes a estrada encuberta ou junto della no arcem acha mais largo sitio para as batarias, onde póde alojar muyto numero de artelheria contra as praças baixa e alta do flanco, ficando por esta cauza o inimigo com ventagem, o que he grande inconveniente.

A terceyra razão contra os fossos largos he que quando são mais largos se descobre mais a parte inferior da muralha, e assim se póde arroinar mayor altura della, com que se disporá a sobida mais facil, ao que tambem ajuda a pouca profundidade que suppomos quando o fosso he mais largo na forma que propoem a questão.

A quarta razão he que as obras exteriores se defendem mais dificultozamente por ficarem mais distantes das muralhas.

A quinta que sendo o fosso largo se tornará em incomodo grande aquella conveniencia que os da opinião contraria apontavão na primeyra razão, a saber, que dava muyta terra para a fabrica das obras, porque dará tanta que obrigue a levantar e engroçar os reparos mais do que he necessario, ou a transportar para outra parte a que sobejar, que he hum dispendio inutil.

Pelas quais razões, e pellas que se seguem por parte dos fossos mais fundos posto que menos largos, rezolvo a questão por esta parte, seguindo a opinião do Conde de Pagan Cap. ${ }^{\circ} 5 .^{\circ}$ e são as razões que por esta parte militão as seguintes.[:]

A primeyra, que sendo o fosso fundo ainda que o inimigo entre nelle ficará com mais dificultoza sobida para a muralha pela mayor altura que esta fica tendo. 
A segunda, porque dificulta grandemente as minas ao inimigo, por the ser necessario penetrar muyto abaixo, com risco de topar com agua, ou pedras, principalmente havendo refossete ${ }^{76}$; e ainda que não intente passar com mina, mas atraveçar com galaria, ou espalda, sempre terá mayor dificuldade em penetrar tanto abayxo, e em se haver de cobrir.

A terceyra he que sendo o fosso fundo se topará mais vezes com agua, e ficará logrando as commodidades que tem os fossos aquaticos.

As quais razões se acrescenta que seção [cessam] nesta opinião aquellas cinco objecções apontadas contra a largura dos fossos pello que estes serão melhores mais fundos posto que menos largos, do que pello contrario.

Nem obsta que digão que por sua profundidade se podem defender mal das praças altas a respeyto das grossuras dos parapeytos, porque se responde que nós determinamos o fosso de 14 athe 18 pés [ $4,62 \mathrm{~m}$ até $5,94 \mathrm{~m}$ ] de fundo, e sobindo a praça alta outros 18 ou 20 [5,94m ou $6,6 \mathrm{~m}$ ] sobre o livel da campanha fica sobre o do fosso elevada somente 38 [12,54m], com que dispondo o parapeyto na forma que adiante diremos ainda se descobrira mais de a metade da cortina ficando o parapeyto á face da muralha do flanco, e muyto mais ficando retirado todo o vão que occupa a praça bayxa, com que seça [sic] a objeção.

Não obsta em segundo lugar o dizerem que sendo o fosso profundo se arroinarão por esta cauza seus lados se não forem revestidos de muros, porque a isto se responde que na nossa fabrica ficão as muralhas fazendo lado interior ao fosso, poys sahem do

\footnotetext{
${ }^{76}$ Pequeno fosso, mais estreito, escavado no fundo do fosso maior. Ver Fig. 31 Seg. da Est. 15 , segmento RR.
} 
fundo delle, e no que toca ao lado exterior que chamão contrascarpa se faz com tal declividade que bem se póde sustentar sem roina, ainda que não seja revestida ${ }^{77}$.

Não obsta ultimamente em terceyro lugar que sendo o fosso profundo dará mais terra da necessaria para as obras, e por tanto será necessario engroçar, e levantar mais do que convem os reparos, ou transportalla para outra parte, que he o mesmo que arguiamos [sic] contra os fossos muyto largos, porque se responde que esta objecção não procede no fosso de 18 pés [5,94m] de fundo segundo as obras que he necessario fazerem-se da terra que delle sahe, e que ainda que se faça mais fundo se poderá estreytar na largura, por evitar este inconveniente, fazendo primeyro o compito trigonometricamente da terra que he necessaria para as obras e abrindo o fosso nessa conformidade, seguindo sempre antes o mais fundo que o mais largo.

\author{
Questão 2. ${ }^{\mathrm{a}}$ \\ Qual he melhor se o fosso seco \\ ou aquatico.
}

Nenhu'a questão he mais debatida que esta entre os Architectos melitares: Antonio de Ville liv. $1^{\circ}$ Cap $^{\circ} 37$ diz que elle tem a rezolução por dificultoza, pelas razões que melitão por hu'a e outra parte a cerca dos fossos das praças reays; que quanto naquellas fortificações que se fazem somente para sustentar hum impeto, como os castellos, e outros fortes fabricados em passagens, e outros lugares que convem segurar, para que o inimigo os não occupe, e se fortifique nelles, como tambem nas cidadellas que se fazem para meterem respeyto a algum povo

\footnotetext{
${ }^{77}$ Em resumo, procuravam o que chamamos de ângulo de talude natural do terreno para evitar a necessidade de contenção da encosta da contra-escarpa.
} 
trebulento [turbulento] de cuja rebelião o Principe se tema se confirmão os AA [autores] em que são melhores os fossos cheyos de agua, porquanto estes lugares não são fortificados para sustentarem cercos, e assim não necessitão os defensores de fazerem sortidas, por não serem os tays lugares capazes de tanta gente que as possão fazer sem detrimento, e diminuição do prezidio necessario; nem se possão por sua debilidade defender contra sitio dioturno de exercito aquartelado; convem por tanto que os fossos sejão cheyos de agua (havendo para isto comodidade) porque assim estão mais seguros contra as entreprezas, por cuja cauza diz Ville se buscão muytas vezes para a situação destes fortes lugares cercados de ribeyras, como o forte de Santo Antonio junto de Bomel; o de Schenxenchans, e outros fundados em diversas partes dos Paizes bayxos, onde facilmente se dá esta eleyção de sitios para o tal intento; com a mesma concideração foy eleyto o sitio de Komorra em Ungria, o qual he cercado do rio Danubio por 3 p. tes. $^{\text {. }}$

Tratando poys da questão acerca dos fossos da praças reays capazes de rezistirem a sitio de exercito numerozo, sustentão muytos a parte dos fossos aquaticos, fundados em que segurão as praças de escaladas, e entrepezas [sic], a qual razão aponta Dogen liv. $1^{\circ}$ Cap. 11 por unico cómodo dos tays fossos; Ville, Fritach, Lorine, Medinabarba [Medina Barba], Rochas [Roxas], Tensine ${ }^{78}$, Antonio Sarti ${ }^{79}$, e Pedro Sardi, que todos sustentão a parte dos fossos aquaticos, acrescentão mais as razões seguintes.

\footnotetext{
${ }^{78}$ Francesco Tensini, Cavaleiro de Crema, começa a sua vida militar com 17 anos. Combateu em Flandres, na Alemanha e na Itália e participou de dezenas de assédios a praças fortificadas. Serviu ao Rei da Espanha, ao Duque da Baviera. O seu texto mais famoso é La fortificatione, guardia, difesa, et espugnatione delle fortezze, publicado em Veneza no ano de 1624.

${ }^{79}$ Antônio Sarti era italiano de Luca. O seu texto de fortificação não pretende apresentar nenhum sistema, mas dissertar sobre as fortificações, de maneira geral. Foi mestre de seu filho Paolo Sarti, também um experto das fortificações. Editou em Veneza no ano de 1626 o tratado intitulado L'aurora delle opere di fortificazione, e di guerra.
} 
A segunda que o fosso cheyo de agua he mais difficultozo de segar [sic], e passar que o seco.

A terceyra que se o inimigo o sega não tem outra passagem para chegar as muralhas mais que aquelle entulho que nelle fez para passar, sendo que hu'a vez entrado nos fossos secos se póde estender para qualquer parte, e fazer diversos ataques.

A quarta, que sendo o fosso aquatico tem o inimigo muyto mayor difficuldade em se cobrir com a traveça que chamão espalda.

A quinta, que havendo o inimigo passado pello entulho que fizer, ou por meyo de ponte arteficial q' fizer (o que sempre será com grande risco) poderá o defensor accodir á defença com mais gente e segurança, poys pellas outras partes em que ha agua no fosso fica com ella mais guardado, e por tanto necessita de menos guarnição, e sentinellas.

A sexta, que impede grandemente a execução das minas.

A setima que isto se confirma com o exemplo das praças de Holanda, e Zelanda onde quazi todos os fossos são cheyos de agua, e tem mostrado a experiencia sua bondade em quantos sitios, e defenças naquelles paizes tem havido.

A outava com que finalmente pertendem [pretendem] corroborar esta opinião he a experiencia do que os sitiadores obrão quando atacão hu'a praça com fosso de agua, que primeyro tratão (se podem) de o sangrar, e esgotar, o que não farião se lhe não cauzara mayor embaraço e impedimento que o seco: por parte do qual outros alegão as razões seguintes.[:]

Primeyra que a defença não pende [depende] de serem os fossos secos, ou aquaticos, mas sim da vegilancia, e esforço dos defensores; e que estes dentro dos fossos secos podem fazer muyto mayores defenças, em respeyto de que dentro nelles se podem 
fazer muytas cortaduras, cofres, ou capoeyras ${ }^{80}$, e outras invenções com que embaraçar e retardar o inimigo, como se vio em Mastrich onde o fosso era em parte seco, e em parte aquatico, e sendo sitiada pellos Holandezes, escolheu o Principe de Orange para a opugnar por mais facil a parte do fosso seco, levado da opinião mais aprovada daquelle tempo, de que era mais difficultozo o aquatico, e achou tantos impedimentos por sahidas e minas, e outras obras dos defensores que veyo a conhecer á custa de muyto sangue a mayor dificuldade do fosso seco, e d'ali por diante se começou a seguir a opinião contraria aos aquaticos, o que ja havião experimentado os Espanhoys com grande dáno seu em Bergemepzoem que defendião os Holandezes.

Que pello contrario nos fossos aquaticos se não podem fazer as obra sobreditas, nem decerem os soldados a defendelos impedindo-o a agua.

A segunda razão he que nos fossos secos por toda a parte com muyto mayor facilidade e promptidão podem os defensores socorrer as obras exteriores, ou seja hindo a ellas pello plano do fosso, ou por caminhos subterraneos que devem estar preparados do tempo da fabrica, tapadas as serventias de q' so devem ter noticia os cabos principays, para na occazião se servirem delles sendo necessario em socorro das ditas obras exteriores: assim mesmo podem fazer as sortidas, ou seja so com a infanteria, ou tambem com a cavalaria, o que nos fossos aquaticos não póde ser, antes he tudo pello contrario: não se póde accodir bem as obras exteriores se não por ponte, a qual o inimigo procurará de flanquear: e quanto as sortidas para se fazerem em bateys será perigozo passar nelles

\footnotetext{
${ }^{80}$ Capoeira é uma comunicação que atravessa o fosso protegida por dois parapeitos.
} 
o fosso á vista do inimigo; e sendo constrangidos os que sahirem a retirarse o não poderão fazer sem grande confuzão, e perda de gente pella difficuldade de entrarem nos bateys, e ficarem muytos expostos ao perigo, ou á necessidade de passar a nado, largando as armas ainda que saybão nadar, e esta dezordem será ainda mayor se as sortidas se fizerem com cavalaria, pella mayor difficuldade de entrar nos bateys quando venha opremida do inimigo.

O exemplo do perigo destas retiradas se vio em Bredá sitiada pellos Holandezes, onde de hu'a parte os Francezes, de outra os Inglezes que com elles militavão fizeram em competencia duas minas dirigidas a hum hornaveque no qual (posto que foy defendido valerozamente) cederão finalmente os Espanhoes, e querendose retirar a hum revelim separado do hornaveque por hum fosso de agua, acodirão todos a hu'a pontezinha por onde se comunicavão larga somente pé e meyo [0,44m], e embaraçados com o tropel forão obrigados a se lançarem muytos no fosso carregados com as armas, e cançados da peleja, onde mizeravelmente se afogarão, o que não sucederia se o fosso fosse seco, e se poderião salvar por elle.

A terceyra razão he que sendo os fossos secos obrarão melhor os arteficios de fogo que nelle se lançarem contra o inimigo para the queymar a fachina e madeyra com que pertende cobrirse; e que tambem se póde acodir de dia à tirar e recolher para dentro a dita fachina, e madeyra, ou qualquer outra materia com que o inimigo faça o entulho, e que tem a commodidade de se poder em tempo de hum sitio recolher nelle o gado do contorno para sustento da praça.

A quarta razão he que os fossos de agua quando esta não he corrente gerão roins ares principalmente nas terras quentes onde logo a agua quieta se conrompe [sic], e cauza muytas doenças, 
por cuja cauza em Setubal se mandou outra vez entulhar o fosso que estava principiado nos baluartes do rocio, por não ter vazão a agua que ali ficava no inverno. E se a agua se congelar como de ordinario sucede nas provincias do Norte he muyto mayor o risco que nos secos, poys fica a praça como se não tivera fosso, podendose passar por sima do gello, e por esta cauza he necessario aos moradores que tenhão cuydado de o quebrar athe darem na agua liquida debayxo: isto se vio em Uvachtendonck tomada pello conde de Nasao por entrepeza [sic], á qual the deu occazião o fosso gelado, porque descuydados os moradores de quebrar o gello, os Holandezes hu'a noyte accommetendo por sima do gello matarão as sentinellas, e logo quebrando as portas entrarão dentro; refere a istoria Reidanno nos Annaes liv. 17.

Pella mesma cauza houve outra semelhante entrepeza [sic] em Philipopolis cidade principal do Rim [sic] que estava prezidiada de Francezes, os quais descuydandose de quebrar o gello do fosso deyxarão passo franco por sima delle aos Alemães, que chegando de noyte tiverão lugar de atarem fortes cordas na estacada por fora do fosso, as quais prezas aos cavalos, e picando-os a hum mesmo tempo forão com aquelle impeto levadas as estacas, flanqueando o passo por sima do gello do fosso, ganharão a cidade; refere hu'a e outra couza Dogen.

Finalmente dizem os desta opinião que a agua não difficulta tanto as entreprezas que se não possão conseguir, porque muytas se tem conseguido, o que se vio em Bredá cuja istoria refere o Cardial Bentivoglio $\mathrm{p}^{\text {te }} 2^{\mathrm{a}}$ liv. $5^{\circ}$ pag. 145 . Atraveça a Bredá o rio Mrach, banhando hum Castello que pella parte interior entesta com a muralha; tres legoas da praça dezemboca o rio em hum largo canal dentro em Holanda; pemitiase que com passaporte se 
comonicassem em barcas de hu'a e outra parte, com cuja permição vinhão algu'as carregadas de turma [?] ${ }^{81}$; despachavão estas barcas no Castello de Bredá; com esta occazião era ja conhecido dos soldados certo Holandez patrão de hu'a barca, costumava ir e vir muytas vezes, propos este ao Conde Mauricio que na sua barca debayxo da turma [?] podia hir escondido bom numero de soldados, e conseguirse hu'a entrepreza em Bredá; satisfesse o Conde da proposta, dispose a entrepreza, e na barca deste patrão se meterão pouco menos de 80 soldados escolhidos a ordem do Cap ${ }^{\text {am }}$ Carlos Aharauger escondidos debayxo da turma [?] que hia sobreposta em huns taboens armados em falso; chegou a barca ao Castello, ordenou o Cap ${ }^{\text {am }}$ da guarda se vezitasse na forma ordinaria, mas os seus officiays o fizerão com pouca deligencia, daqui tomou mais animo o patrão, e começando a mover praticas foy entretendo o tempo com ditos e zombarias, e dahi vierão aos brindes, e mantendo os soldados o invite se vieram a carregar de maneyra que huns cahirão, outros se retirarão a dormir ao Castello; vendo o patrão a occazião prompta abrio os taboens, sahirão os soldados escondidos, entrarão no Castello, assaltarão os do prezidio, que atonitos da novidade conhecendo ser entrepreza, perderão o animo, e sem fazerem oppozição alguma fogirão e dezempararão o Castello, ficando mortos e feridos alguns delles no primeyro assalto, e prezioneyro o Capam Paulo Antonio; chegou então o Conde de Holach, e pouco depoys o Conde Mauricio com o socorro que estava disposto, com cuja vinda fogio o prezidio da Cidade,

\footnotetext{
${ }^{81}$ A leitura da palavra que fizemos no texto foi turma. É, entretanto, uma expressão que não pode ter o sentido atual da palavra que é de grupo de indivíduos reunidos para um determinado escopo ou no sentido antigo empregado pelos romanos de grupo de trinta cavalarianos. Parace mais um material transportado pelas barcaças porque 0 texto afirma adiante: escondidos debayxo da turma que hia sobreposta em huns taboens armados em falso.
} 
e a deychou dezemparada [sic] com o passo franco do Castello para ella, por cuja cauza forão depoys castigados todos os do prezidio, que era gente Italiana, a qual nota o Cardial nunca fizera acção tão indigna como esta.

Tambem foy ganhado pellos Espanhoes por entrepreza Schenckenschans sem embargo que este forte he guarnecido do melhor fosso que póde ser de agua corrente, poys o cercão por duas partes dous famozos rios o Rhin, e Ewael, e pello resto tem hum fosso de agua derivada a dos mesmos rios, com o que a agua não impossibilita as entreprezas ainda que consedamos que algum tanto as dificulta.

Estas são as razões principays por huma e outra parte e por ambas são forçozas com que a questão se póde defender problematicamente, mas sendo forçozo eleger alguma das partes, pezão mais as razões por parte dos fossos secos, e nellas se responde as que se alegão por parte dos aquaticos, e assim os mais dos architectos militares modernos seguem aquella parte.

Nem he necessario fazer a destinação que alguns fazem do tempo da guerra ao tempo da paz, querendo que no da guerra seja melhor o fosso seco, no da paz aquatico; porque se no tempo da guerra he melhor o seco, isso basta, poys para esse tempo he que se fortificão as praças, e se fazem os fossos.

\section{Questão 3. ${ }^{\mathrm{a}}$}

Se a contraescarpa deve ser revestida de muro de pedra e cal, ou não.

Querem alguns que a contraescarpa não deve ser revestida, porque havendo o inimigo chegado a ella se poderá servir do muro por parapeyto de seus alojamentos, que junto delle fará, e abrindo 
nelle canhoneyras fará grande d'ano aos que aparecerem dentro do fosso, como se vio em Famagusta o anno de 1570 que vindo o Turco sobre ella se arrimou a estrada encuberta e foy penetrando athe chegar a muralha da contraescarpa, e pella achar forte se valeu della para se cobrir, e por detras della fes largas e profundas sahidas subterraneas para o fosso, e abrio no mesmo muro muytas torneyras [troneiras] donde laborava com sua mosquetaria contra o fosso e contra a praça, segundo refere Lorine liv. $1^{o}$ jornada $5^{a}$.

Com tudo como a terra da contraescarpa não he materia apta para rezistir aos danos do tempo sem detrimento da estrada encuberta, e do deligniamento que se the hover dado, principalmente no tempo de inverno com as aguas da chuva que se juntão no fosso e tambem que com quaisquer instromentos se póde nella fazer sobida por onde o inimigo entrado no fosso possa tornar a sobir, parece mais conveniente revestir-se a dita contraescarpa com tal advertencia que o muro não seja groço, porque delle se não valha o inimigo, antes o mais delgado que puder ser, conforme a tenacidade do terreno para que a artelheria o possa facilmente desfazer, e com esta concideração o Capitão Antonio Sarti no quezito 27 , Pedro Sardi na pratica pagina 22, e outros o quizerão fazer de pedra seca.

Pello que quando a terra for boa, e bastante, que per si so se sustente como ordinario succede na contraescarpa por ficar ali em seu sitio natural, em tal cazo se lhe póde fazer a camiza de muro de pedra seca rebocado de cal, poys que não he para servir de arrimo á terra, mas so de a defender das aguas, e injurias do tempo, porem se o terreno em que se abre o fosso for pouco firme, se fará o muro de pedra e cal para que lhe sirva não so de defença, mas tambem de arrimo, accommodando-o sempre da menor groçura que puder ser 
conforme a qualidade do terreno, para que a artelheria o possa facilmente desfazer; e neste cazo eu fizera o dito muro encostado ao mesmo terreno, e com escarpa ao terço, porque como o terreno não peza contra o muro o não poderá derrubar, e se o inimigo ganhar a contraescarpa, e quizer decer ao fosso por detras do muro este senão poderá sustentar faltandolhe a terra, com que seçará [sic] a razão contraria asima referida.

\section{$\mathrm{Cap}^{\circ} 24$}

DA FORMA DE DESENHAR OS FOSSOS.

Assentado como maxima geral que a contraescarpa do fosso não deve ser parallela á face do baluarte mas sim obliqua, o que todos os modernos, e ja muytos dos antigos seguirão, restanos dizer quanta deva ser essa obliquidade para que o tal fosso não fique com demaziada largura defronte da cortina, nem tambem muyto estreyto defronte do angulo flanqueado; e assim para obviar qual-

Fig. 28 [Est.14] quer destes defeytos se parta o flanco por exemplo o flanco AB, ou $\mathrm{CD}$ em doze partes iguais, e com a distancia de qualquer delles se tiverem as linhas GH e GI parallelas as faces dos baluartes, athe toparem com as capitays ZE, e ZF produzidas; partão-se pello meyo as linhas GH, e GI, nos pontos $\mathrm{P}$ e R, então dos pontos A e C angulos da espalda se tirem pelos ditos pontos $\mathrm{P}$ e $\mathrm{R}$ as linhas LRM, LPN as quais terminarão a contraescarpa do fosso obliquo: finalmente pondo o pe do compasso nos angulos flanqueados, E, e F, com as distancias FM, EN, se descrevão os redondos $\mathrm{MV}, \mathrm{NV}^{82}$.

\footnotetext{
${ }^{82}$ O autor continua a fazer uso da Fig. 28, Est. 14 para explicar o desenvolvimento do seu traçado.
} 
Isto se obrará no quadrado, e no pentagono, mas do exagono athe o undecagono incluzive, se tome a duodecima parte do flanco começando do ponto $\mathrm{A}$, ou $\mathrm{C}$ athe $\mathrm{M}$, ou $\mathrm{N}$, e do duodecagono athe a figura de 24 lados excluzive se tomarão os $2 / 12$, ou $1 / 6$ do flanco $\mathrm{AB}$, ou $\mathrm{CD}$ para dahi se tirar a linha da contra escarpa pelos pontos R, e P. Da figura de 24 lados athe a de 36 tambem excluzive se tirarão as tays linhas dos $3 / 12$ ou $1 / 4$ de todo o flanco. Da figura de 36 lados incluzive athe a de 48 excluzive, se tirarão dos 4/12 ou $1 / 3$ do flanco, e se obrara da mesma forma. Da figura de 48 lados incluzive athe a de 60 excluzive se tirarão as ditas linhas dos $5 / 12$ do flanco, e finalmente da figura de 60 athe linha recta tambem incluzivé se tirara a dita linha da contraescarpa dos $6 / 12$ ou a metade do flanco $\mathrm{AB}$, ou $\mathrm{CD}$ que he o mesmo.

He de advertir que admitimos aqui a largura do fosso parallelo ás faces dos baluartes, para depoys se descrever o obliquo, igual ao comprimento do flanco, quando este não exceder 120 pés [39,6m], por ser esta largura a que basta ainda para as mayores praças.

Para desenhar os fossos nas praças irregulares se uzará da mesma pratica, advertindo porem, que em cada lado se desenhará respectivamente conforme a figura porque foy fortificado como quadrado, ou como pentagono se lançará a linha que forma o fosso obliquo do angulo da espalda; mas se for fortificado como exagono athe o duodecagono excluzive se tirará a sua obliquidade da duodecima parte do flanco; e se como duodecagono athe a figura de 24 lados excluzivé se tirará de 1/6 do flanco, e assim se hirá continuando nas mais figuras, na mesma forma que ensimos [ensinamos] nas regulares.

Mas porque nas praças irregulares succede comummente que as faces de hum baluarte não são iguais, pelo não serem os lados que formão o angulo da figura, e haver neste cazo de ser o fosso de 
hu'a parte mais largo do que da outra de que rezultará que a redondeza que se deve fazer defronte do angulo flanqueado se não poderá formar da ponta do mesmo angulo, como dissemos nas figuras regulares, neste cazo obraremos do seguinte modo ${ }^{83}$.[:]

Fig. ${ }^{a}$ 29 [Est.14]

Do ponto A angulo flanqueado sobre a contraescarpa mais distante se deyte a perpendicular AI, tomese a distancia IM, no qual concorrem as contraescarpas, e se transfira de $\mathrm{M}$ athe $\mathrm{N}$ na contraescarpa menos distante; do ponto $\mathrm{N}$ se levante a perpendicular NP, a qual cortará a perpendicular AI no ponto $\mathrm{P}$, e este será o centro donde com h um cordel (como se pratica na campanha) se descreverá a dita redondeza com a distancia IP, ou NP, á qual redondeza será tangente a qualquer das contraescarpas obliquas.

Supposto que este modo de desenhar os fossos assim nas praças regulares, como irregulares seja dos melhores que trazem varios AA [autores], por ficar por este modo descuberta de todo o flanco primario, e ainda de parte do secundario toda a contraescarpa, e redondeza opposta, com tudo apontarey a que outro modo que se asemelha muyto ao de Antonio de Ville, para que quem quizer possa escolher aquelle de que mais se agradar.

He poys o dito modo o seguinte.[:] Do ponto D angulo flanqueado se levante a perpendicular DE sobre a face DG, igual ao flanco $\mathrm{GH}$ : della se corte a decima parte $\mathrm{EF}$, ficando notado o ponto $\mathrm{F}$, partase o flanco opposto $\mathrm{AB}$ em dez partes de $\mathrm{A}$ athe $\mathrm{B}$. Logo do ponto A angulo da espalda extremo do flanco BA se tire pelo ponto $\mathrm{F}$ a linha $\mathrm{AF}$, a qual terminará a contraescarpa, que servirá para o quadrado e pentagono.

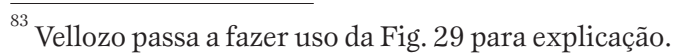


Para o exagono se tome a decima parte do flanco $\mathrm{AB}$ de $\mathrm{A}$ athe $\mathrm{E}$, e do ponto $\mathrm{E}$ se tire a linha EF a qual formará a contraescarpa.

No Heptagono se tomem os dous decimos, ou 1/5 do dito lado $\mathrm{AB}$ de $\mathrm{A}$ athe $\mathrm{I}$, e do ponto I se tire a linha IF e esta terminará a contraescarpa ${ }^{84}$.

No octogono se tomem os 3/10 do flanco $A B$, e do ponto onde se terminarem se tire ao ponto $\mathrm{F}$ a linha que determinará a contraescarpa.

No eneagono se tomem os $4 / 10$ ou $2 / 5$ do mesmo flanco, e do seu ponto terminativo se tire a linha da contraescarpa; o mesmo se fara no decagono, e no undecagono.

No duodecagono, e em todas as mais figuras athe a linha recta incluzive se tomarão do dito flanco $A B$ os $5 / 10$ ou $1 / 2$, e desse ponto medio se tire a linha que forme a contraescarpa.

Ja dissemos asima que este modo se asemelha muyto ao de que uza Antonio de Ville liv. $1^{\circ}$ p $^{\text {te }} 2$ Cap. ${ }^{\circ} 39$ pag. 131 donde quem quizer o póde ver.

Não falta quem faça o fosso dandolhe catorze braças [30,8m] de largo defronte do angulo flanqueado e dahi tira a contraescarpa parallela a linha fichante porque por este modo evita que o angulo reintrante da contraescarpa não tire parte da defença que póde receber toda a face do flanco recto opposto.

$\mathrm{O}$ autor do Engenheyro Portuguez ${ }^{85} \mathrm{p}^{\text {te }} 2 .^{\mathrm{a}}$ liv. $2^{\circ} \mathrm{Cap}^{\mathrm{o}} 9$ pag. 140 aponta outro modo, que he tirando dos angulos flanqueados duas linhas aos angulos da espalda oppostos, fazendo o resto

${ }^{84}$ Este traçado está confuso pela sua descrição em virtude de não ter sido indicado no desenho onde se encontra o ponto I.

${ }^{85}$ Curiosamente o nome do Brigadeiro Manoel de Azevedo Fortes nunca é citado textualmente quando é referido o seu tratado. 
parallelo as faces athe o encontro das primeyras linhas, e diz pouco mais adiante que necessariam ${ }^{\text {te }}$ nos havemos de servir deste modo para os baluartes em linha recta, e nos angulos do poligono demaziadamente obtuzos, porque se em huns e outros se uza so do primeyro desenho ficarião os fossos demaziadamente largos.

Tendo dito athe aqui da largura dos fossos, e diversos modos de os desenhar seguese dizermos da sua profundidade a qual não deve ser tanta que do alto do parapeyto dos flancos se não descubra a raiz da muralha ao menos athe o meyo da cortina, nem tambem tão pouca que possa o inimigo facilmente ou segalo [cegá-lo], ou saltar nella tendo entrado na estrada encuberta; e ainda tem outro inconveniente que he não dar toda a terra q' baste para os parapeytos, e terraplenos, pelo que deve ser de hu'a medrioque [medíocre] profundidade, e assim Monsieur de Vauban, o autor anonimo lhe dão tres braças $[6,6 \mathrm{~m}]$ e athe tres e meya $[7,7 \mathrm{~m}]$ o mais; o nosso Engenheyro Portuguez diz que se póde fazer de duas braças $[4,4 \mathrm{~m}]$ de fundo, como fez o mesmo Monsieur de Vauban em algu'as praças que fortificou (teria razão particular para assim o fazer) nesta variedade não será fóra de razão tomar meyo, e fazello de duas braças e meya [5,5m] de fundo e sendo q' seja forçozo fazella mais fundo se poderá chegar athe as tres sem passar dahi porque sendo mais profundo, como tem bastante largura dará tanta terra que sobre das obras que com ella se costumão fazer e não ha donde se transporte sem hu'a grande despeza.

Alguns Engenheyros, (e não são os de peyor nota) costumão fazelos em declive da raiz da cortina para o angulo da contraescarpa, e deste vão outra vez decendo para o angulo flanqueado, conseguindo por este modo mayor profundidade defronte da face do baluarte, donde he mais necessaria, e menor na cortina donde não convem que tenha muyta, pelos inconvenientes ja apontados. 
Póde haver occazião por cauza do terreno ser rocha na qual se não poderá profundar tres $[6,6 \mathrm{~m}]$, nem ainda as duas braças e meya $[5,5 \mathrm{~m}]$ que admitimos, neste cazo se profundará so duas, que he o menor termo que admitimos em cazo de necessidade.

$$
\mathrm{Cap}^{\circ} 25
$$

\section{DOS REFOSSETES}

Havendo tratado dos fossos com que se costumão cercar todas as praças, não parece vir fora de seu lugar o tratar dos refossetes com que muytos querem aumentar a defença, e dificultar ao inimigo o accesso da praça, porque entrado no fosso principal acha de novo este impedimento (que não he pequeno) para se aproximar a muralha.

Não falta quem os reprove, sendo hum destes o autor anonimo do novo methodo de fortificar a Franceza dando por razão que servem mais para cobrir os inimigos do que para ventagem dos defensores, e so os admite sendo cheyos de agua; mas seguindo a opinião de outros muytos autores dizemos que são uteys, e que aumentão muyto a defença, porque sobre a margem interior delle se faz hum parapeyto em que assistem mosqueteyros, e muytas vezes tambem artelheria com que muyto se offende, e retarda o inimigo.

Assentado que he conveniente haver refossetes podendo ser, dizemos tambem que se estes puderem ser cheyos de agua será muyto melhor, porque assim fica seçando a razão que dá o dito autor anonimo de que o inimigo se cobre com a sua margem interior; dizem os mais que se esta agua puder ser de sorte que se possa encher e vazar todas as vezes que se quizer, que ainda será $\mathrm{m}^{\text {to }}$ melhor, porque assim se evita que se conrompão, e cauzem infermidades na guarnição. 
Fazem-se estes tays refossetes bem no meyo do fosso da praça principal, de outo [oito] athe doze pés [2,64m ate $3,3 \mathrm{~m}$ ] de fundo podendo ser, porque muytas vezes se topa com agua que os não deyxa profundar de largo the dá Sardi a terça parte da largura do fosso principal, mas esta largura temos por demaziada porque entre a margem interior, e a muralha não deyxa suficiente capacidade para se fazer hum parapeyto groço, e estarem os defençores: Antonio de Ville no seu governador de praças Cap. 20 pag. 129 os admite de 18 athe 24 pés $[5,94 \mathrm{~m}$ até $7,92 \mathrm{~m}]$ de largo, e de fundo o que puder ser athe que tenhão cinco ou seis pés $[1,65 \mathrm{~m}$ ou $1,98 \mathrm{~m}]$ de agua.

O nosso Methodo Luzitanico the dá a quinta parte da largura do fosso principal e o mais athe a quarta parte, no que não vay fóra de razão, porque ja da sua margem interior para dentro fica suficiente terreno para se fazer parapeyto, pôr artelheria, e estarem os defençores.

Quando o fosso principal for obliquo ás faces dos baluartes, se deve advertir que a margem exterior do tal refossete deve correr parallela com a contraescarpa do fosso, e a margem interior será parallela com as faces dos baluartes, porq' assim vem a ficar com a mesma obliquidade que o fosso principal da praça.

As suas escarpas costumão ser ao terço ou ao quarto da sua altura, conforme a qualidade do terreno em que se abre o refossete, e sempre he acerto fazerse a escarpa interior com mayor talud, ou baze do que a exterior, porque se o inimigo o ganhar fique exposto, e descuberto da praça de donde se descortina todo o seu fundo.

Não se costumão revestir de parede de pedra e cal como se faz á contraescarpa do fosso principal, assim porque a póde escuzar, como por se poupar esta despeza, que não he pequena.

Quizerão alguns Engenheyros introduzir outra casta de fosso adiante do parapeyto da estrada encuberta, dizendo que assim 
dificultavão mais ao inimigo o aproximarse a praça, e o vir alojarse sobre a mesma estrada encuberta, mas universalmente he hoje reprovada de todos esta fabrica, porque dizem que chegando o inimigo a ganha-lo acha hum aproxe feyto contra a praça, no que mostrão razão e assim escuzamos de dizer a sua deligniação.

$\mathrm{Cap.}^{\circ} 26$.

\section{DA ESTRADA ENCUBERTA, SEU PARAPEYTO, E EXPLANADA.}

A estrada encuberta ${ }^{86}$ se forma por linha parallelas a contraescarpa do fosso; varias são as larguras que lhe asignão os AA [autores], porque Antonio de Ville a faz de 18 [5,94m] athe 24 pés [7,92m] de largo, e quer tambem que seja seis palmos [1,32m] mais bayxa que o livel da campanha. Adam Fritach, e Mathias Dogen a varião conforme o numero dos lados da figura, asignando para os lados digo quadrado 12 pés Rinthlandicos [3,72m] (são alguma couza mayores que os nossos pés Portuguezes) ${ }^{87}$ para o pentagono, e exagono 15 , no eptagono 17; no octogono, e eneagono 21 , e aqui parão dando a mesma largura em todas as mais figuras de mayor numero de lados; Niculao Glodman [Goldman] asigna seis pés [1,98m] $\mathrm{p}^{\mathrm{a}}$ os fortes a que chama quadrantays que são aquelles que tem

\footnotetext{
${ }^{86}$ Os autores portugueses usam tanto a expressão estrada coberta (ou cuberta) [Azevedo Fortes e outros] como estrada encoberta, mas Serrão Pimentel declara que esta última forma é a mais correta: (ephiteto mais apropriado que cuberta; como vulgarmente lhe chamão com [sic] os Autores, significando a palavra cuberto algúa cousa mais que encuberto).

${ }^{87}$ Esta informação está em conflito com o que se vê na "tabuada" de Serrão Pimentel, através da qual obtemos comparação de diversas medidas européias. O valor aí assinalado para o pé, dito, Rinthlândico é de, aproximadamente, $0,31 \mathrm{~m}$, ou seja, ligeiramente inferior ao pé português $(0,33 \mathrm{~m})$ e não superior, como afirma Vellozo. Mesmo que a impressão da tabela nos deixe dúvidas sobre alguns números, ela foi composta com o valor crescente das medidas e o pé português está depois de pé Rinthlândico.
} 
a defença curta, que he segundo a quarta parte do tiro de mosquete: sete $[2,31 \mathrm{~m}]$ nos demidiatos que são os que a tem segundo a metade do tiro de mosquete; nove $[2,97 \mathrm{~m}]$ nos dodrantays que são aquelles que a tem aos 3/4: doze [3,96m] nos castellos ou fortalezas que ja merecem o nome de reays ainda que pequenas, e tanto vão estas crescendo em grandeza assim the vay acrescentando a largura da estrada encuberta até 27 pés [8,91m] termo em que pára; outros lhe dão diversas larguras, mas tudo vem a parar em que a fazem de $6[1,98 \mathrm{~m}]$ athe 30 pés $[9,90 \mathrm{~m}]$ conforme a grandeza da praça.

O nosso Methodo Luzitanico que tudo procurou porporcionar dá 6 pés [1,98m] de largo as figuras cujo largo exterior for de 200 pés [66m], e daqui para sima vay acrescentando mais 2 pés [0,66m] a dita largura, por cada 100 pés [33m] que o dito lado exterior se for aumentando, e no de 1100 pés [363m] ultimo termo que admite chega a 24 pés $[7,92 \mathrm{~m}]$ termo em que pára por ser ja bastante largura para as mayores praças: e diz que succedendo cair o lado do poligono no meyo de algum dos dous referidos, ou se aproxime mais a hum numero que a outro, como por exemplo, se for de 350 numero entre 300 e 400, ou de 380 numero mais proximo de 400 que de 300 , neste cazo se tomará o numero medio entre os dous termos asignados, a saber, se tomarão 9 para a dita largura, que he o meyo entre 8 e 10, ou se tomarão 10 quando se aproximar mais ao mayor numero; esta largura se entende livre do espaço que occupão as banquetas ${ }^{88}$, excepto quando a dita estrada encuberta for ja tão larga que possa admitir se fação as ditas banquetas sem perjuizo [sic] da sua largura.

\footnotetext{
${ }^{88}$ Pequeno degrau na estrada encoberta ou junto aos parapeitos (das muralhas ou das estradas encobertas), onde sobem os atiradores de mosquete para disparar as armas em posição mais confortável ou, como diz textualmente o nosso autor: para que os soldados nella se possão pòr em postura de atirar.
} 
Não falta quem faça a estrada encuberta mais larga defronte do angulo flanqueado da praça do que defronte da cortina hindo incencivelmente [sic] alargando-a do angulo da contraescarpa para o opposto ao flanqueado isto se póde admitir quando a estrada encuberta não for de suficiente largura, porque assim so aumenta aquelle espaço defronte do angulo flanqueado em que de ordinario se costumão pôr corpos de guarda, e ajuntar gente para as sortidas.

Defronte dos angulos flanqueados da praça, e tambem junto dos angulos salientes se lhe costumão fazer huns travezes, ou parapeytos de 9 palmos [1,98m] de alto com sua banqueta, cujos travezes impedem que a estrada encuberta não seja enfiada da campanha, e tambem conduzem muyto para a defença da mesma estrada encuberta, para o que se lhe costuma fazer seu fosso de 27 palmos $[5,94]$ de largo e $9[1,98 \mathrm{~m}]$ de fundo.

O parapeyto da estrada encuberta se fará de 9 [1,98m] athe 10 palmos $[2,20 \mathrm{~m}]$ de alto, com hu'a ou duas banquetas de tres pés de largo; não os admitimos mais altos como quer Antonio de Ville, e outros porque tendo mayor altura necessitão de tres banquetas de que rezulta ser o fogo que delle se faz sobre o inimigo mais retardado, porque hum soldado gasta mais tempo em sobir tres degraos do que dous, e como nove athe 10 palmos [2,20m] bastão para cobrir hum homem he superfluo fazelos de mais; e ainda se dá outra razão que he não serem estes parapeytos fabricados para descobrir ao inimigo na suas trincheyras, mas só para descobrir a campanha, e cobrir os defensores da estrada encuberta.

Estes parapeytos não se costumão revestir de muralha, mas somente de taypa de pilão, ou de adobes quanto baste para ter mão na terra da explanada, e rezistir ás inclemencias do tempo; e ainda que deste recebão algum dáno na occazião do sitio 
se reparão com facilidade. Pela parte exterior não necessitão de escarpa, mas pella interior que olha para a praça se lhe costuma dar de talud hum pé $[0,33 \mathrm{~m}]$ para melhor se sustentar a materia de que forem feytos.

Tambem ás suas banquetas se costuma dar $1 / 4$ de pé [0,08m] de escarpa e terá a primeyra hum pé de alto [0,33m], outro de largo, poys não serve de mais que de hum degrao para sobir á segunda, a qual tera outro pé de alto $[0,33 \mathrm{~m}]$, e tres de largo [0,99m], ou ao menos quatro palmos $[0,88 \mathrm{~m}]$, para que os soldados nella se possão pôr em postura de atirar.

Ultimamente a superficie superior deste parapeyto se faz em declive para a campanha de sorte que com a explanada forme hu'a linha vizual.

A explanada he aquella parte exterior que corre com incencivel [sic] declive do alto do parapeyto da estrada encuberta para a campanha, athe finalizar nella sem algu'a altura: Antonio de Ville lhe dá de largura de 36 [11,88m] athe 60 pés $[19,8 \mathrm{~m}]$; o nosso Methodo Luzitanico quer que possa fazer-se de 50 [16,5m] athe 80 pés $[26,4 \mathrm{~m}]$ ou mais athe fenecer no livel da campanha; muytos AA [autores] querem que a sua largura seja igual ao comprimento do flanco primario; o nosso Engenheyro Portuguez a extende de 15 [33m] athe 20 braças [44m], e diz que não perderá se for mais larga; mas como esta se ha de entulhar da terra que sobra dos fossos poderá ser mais ou menos larga, e tambem será como o terreno o permitir, que nisso vay a dizer pouco ou nada.

Puderamos aqui tratar das obras que se fazem dentro do fosso, para melhor defender a sua passagem; das diversas estacadas que se fabricão na margem exterior do refossete, na estrada encuberta, e adiante do parapeyto sobre a explanada, e ainda por 
bayxo do parapeyto da praça principal, mas rezervamos tudo isto para a segunda parte Orthografica em que tambem havemos de tratar de toda a sorte de obras exteriores com que se costumão cobrir as praças, de seus fossos, estradas encubertas, e explanadas, e finalmente das pontes com que se costumão atraveçar os fossos, assim dormentes como levadiças, e tudo o mais percizo [sic] em hu'a praça real.

Fim desta primeyra parte. 
Parte $2^{\mathrm{a}}$

Orthografica 


$$
\operatorname{Cap}^{\circ} 1^{\circ}
$$

\section{DOS TERMOS E NOMES PERTENCENTES \\ A ORTHOGRAFIA, OU EXPLICAÇÃO DO PERFIL DAS FORTIFICAÇÕES.}

He o perfil (como ja se disse no $\operatorname{Cap}^{\circ} 6^{\circ}$ da primeyra parte Ignografica) huma parte de todo o reparo cortada perpendicularmente ao plano horizontal, onde se mostrão as alturas, e groçuras do mesmo reparo, e suas partes, como tambem as do fosso conforme se ve nas figuras 31 , e 32 .

Reparo, ou vallo he todo aquelle corpo de muralha, e de terra que se levanta em circuito da fortificação, e com o qual se formão os baluartes, e cortinas, reprezentado com as letras ABDIHG: suas partes se explicão pella maneyra seguinte.[:]

AG baze do reparo.

B7 largura superior do reparo.

$\mathrm{CB}$ altura do reparo.

$A B$ escarpa interior do reparo.

AC baze, ou talud da escarpa interior do reparo.

GH escarpa exterior do reparo.

G5 baze, ou talud da escarpa exterior do reparo.

8DIH7 parapeyto, he outro valo da altura de hum homem, que cerca o reparo todo em roda, cuja partes são as seguintes.[:]

8,7 baze do parapeyto.

$9 \mathrm{H}$ altura exterior do parapeyto.

8I altura interior do parapeyto.

$7 \mathrm{H}$ escarpa exterior do parapeyto.

9, 7 baze da escarpa exterior do parapeyto.

IT [ID] escarpa interior do parapeyto. 
IH largura superior do parapeyto com declive para a parte da campanha.

8DE banqueta do parapeyto.

PZ lezira, berma, relexo, ou sapata.

ZQXZ fosso, cujas partes se explicão na seg g $^{\text {te }}$ forma. [:]

ZZ largura superior do fosso.

QX largura inferior do fosso.

Q3, ou X3 altura do fosso.

$\mathrm{XZ}$ escarpa exterior do fosso, ou contraescarpa.

ZQ escarpa interior do fosso.

RV4R refossete: he outro fosso mais pequeno (como ja se disse na primeyra parte) no fundo do fosso principal, cujas partes são semelhantes.

RR largura superior do refossete.

V4 largura inferior.

$\mathrm{RV}$ escarpa interior.

R4 escarpa exterior.

ZY corredor, ou estrada encuberta.

YF1 parapeyto da estrada encuberta cujas partes são F1 declevidade a que chamão particularmente arcen, ou explanada; vay fenecer na campanha sem nenhu'a altura da parte de fora.

YK banqueta do parapeyto da estrada encuberta.

Os Holandezes em suas fortificações (que todas são de terra) ${ }^{89}$ acrescentão outro corpo entre o fosso e o val principal,

\footnotetext{
${ }^{89}$ É por demais conhecida a preferência dos holandeses pelas fortificações de terra. Um dos motivos era o baixo custo e a velocidade de construção muito importante para uma região onde os conflitos eram constantes. Isto estava aliado à dificuldade de encontrar pedras na região e este hábito passaram também às suas conquistas.
} 
deyxando entre hum e outro hum largo espaço, como o espaço GL a que chamão falsabrag $\mathrm{a}^{90}$, com hum parapeyto diante reprezentado com as letras LMNOP.

Mas sendo os reparos revestidos de muralhas de pedra e cal, se costuma, e he melhor que estas sahão [saihão] do fundo do fosso, como se ve na figura $32 \mathrm{em}$ que a muralha se reprezenta com as letras ABDC, escuzando então a falsabraga, cuja falta se ha de suprir com outra obra melhor, como adiante se disputará, e tambem acerca da forma e lugar que deve ter o parapeyto neste cazo de quando as muralhas sahirem do fundo do fosso, porque primeyro he necessario determinar as medidas de cada hu'a das partes do perfil nos capitulos seguintes.

\section{$\operatorname{Cap}^{\circ} 2 .^{\circ}$}

\section{DA ALTURA DOS REPAROS.}

Foy todo e o unico argumento athe agora determinar os comprimentos das faces, flancos, e cortinas, com as quais tres linhas se forma o circuito da fortificação, e sobre cujos vestigios se levantam os reparos; mas como todo o corpo conste de tres medidas, comprimento, largura, e altura, determinar estas duas ultimas he todo o argumento deste e dos seguintes capitulos.

Alto deve ser o vallo, ou reparo para impedir a sobida aos agressores, para que detras delle possão estar seguros os habitantes na praça sem temerem serem descubertos pellos tiros de fora;

${ }^{90}$ Segundo Serrão Pimentel a falsabraga não se pratica nas nossas Fortificaçõens: nas Holandezas é cousa comúa. Ele dá, porém, uma definição para este elemento da maneira seguinte: Caminho das rondas [não confundir com os caminhos de ronda das muralhas antigas], ou Falsabraga he um caminho q' se deixa entre o Reparo, \& a Lisira, ou margem interior do Fosso; [que também se chama de Berma] donde se pòde resistir ao inimigo [...]. 
e para que assistindo os defensores sobre elle, como de lugar dominante, possão descobrir melhor os lugares da campanha, e ferir de longe ao inimigo que quizer chegar-se á praça.

Deve tambem ser largo para que se não tema que os inimigos o possão facilmente desfazer, e penetrar dentro com seus tiros; para que possão commodamente os defensores assistir sobre elle, e plantar sua artelheria como logo se verá.

Mas quanta deva ser a altura, e quanta deva ser a largura, nisto he que consiste toda a dificuldade, sendo todo o excesso por mais ou por menos muyto dannozo, e perjudicial [sic].

Os vallos ou reparos altos agradão a vista, e ostentão fortaleza, mas na verdade perjudição [sic] á defença; e assim favorecem aos inimigos; e para que tanto danno não custe de graça com seu muyto custo gastão o thezouro deputado para a fabrica.

Perjudicão [prejudicam] á defença, e assim favorecem aos inimigos, porque chegandose á praça os encobrem dos tiros dos defensores, e quanto mais se chegão mais se encobrem, e evitão o danno dos tiros, isto experimentarão os Holandezes no sitio de Bredá; tinha fortificado aquella praça Mauricio com grande cuydado e despesa, de sorte que se reputava por hu'a das mais perfeytas da Europa, mas engano-o [sic] a muyta altura dos reparos agradavel como disse á vista, porque depoys cercada a dita praça por Frederico irmão do mesmo Mauricio não puderão os defensores com seus tiros offender aos sitiadores quando ja se vinhão chegando perto, e por tanto forão obrigados a desfazer a altura dos reparos edificados com tanto custo, e abrir nelles algumas roturas em que pudessem por a artelheria mais abatida para com ella desfazer as galerias do inimigo; o que fizerão ja tarde e mal, não sabendo ainda aplicar este remedio por ser morto o 
Engenheyro, e aqui exclama Dogen liv. $1^{\circ}$ Cap. ${ }^{\circ} 10$ pagina 80 contra o uzo (melhor dissera abuzo) da melicia Espanhola, que pospoem os Engenheyros aos mais officiays da melicia com grande ventagem de seus inimigos, quando experimentão que nos sitios das praças ou seja attacando, ou defendendo, val mais a industria de hum bom Engenheyro, que o valor de muytos soldados.

Mas posto que fosse bem aplicado o remedio, nem ainda assim remediavão todo o danno, porquanto abrindo o reparo, este se desliga, e desune, e entre tanto sendo batido mais facilmente se arroina.

Por onde são reprovados com muyta razão aquelles que quizerão proporcionar a altura dos reparos segundo a altura e condição das cazas para as cobrir, o que senão póde meter em pritica [prática] em huma povoação onde haja cazas nobres, e outros edificios altos, segundo os quais seria necessario dar hu'a demaziada altura aos reparos; e ainda quando isto pudesse ser, nem com tudo bastava para ficarem de todo seguras, por cauza do grande danno que fazem as bombas, que igualmente passão por sima dos reparos altos, ou bayxos.

Da mesma sorte que se devem regeytar os reparos demaziadamente altos, se não devem admitir os homildes [sic] e bayxos, porque sendo assim descobrirá o inimigo a gente nelles, como tambem muyto do interior da praça levantando suas baterias, e muyto mais quando se vem a alojar junto de algum sitio superior, pello que se deve escolher huma mediania, não os fazendo demaziadamente altos, nem tambem muyto bayxos.

Antonio de Ville liv. $1^{\circ}$ parte $1^{\text {a }} \mathrm{Cap}^{\circ} 30$ pag. 95 os faz de 20 athe 25 pés geometricos sobre o livel da campanha, que são pés Portuguezes quazi 17 [5,61m] ou 21 [6,93m]; e do fundo do fosso ficarão tanto mais altos quanto for a sua profundidade. 
Fritach liv. $1^{\circ}$ Cap. $^{\circ} 9 \mathrm{diz}$ que sua altura ordinaria são 15 [4,63m] athe 18 pés [5,56m] Rinthlandicos, que são pés Portuguezes de 14 [4,62m] athe $17[5,61 \mathrm{~m}]{ }^{91}$ quazi, e a menor altura que asigna são 12 pés [3,96m], o que se deve entender em fortificações pequenas, e que não merecem nome de reays.

Mathias Dogen segue absolutamente a Frithac ${ }^{92}$, apoyando a sua razão com o uzo das fortificações modernas que não deve passar dos ditos 18 pés [5,94m], e que ainda no cazo que de fora haja padrastros [padrastos] será melhor levantar cavaleyros contra elles, do que levantar o reparo a mayor altura, fundado no discurso largo que no mesmo capitulo havia feyto, de que os reparos não devem subir a demaziada altura pellas razões referidas.

Porem ainda que consedamos se dve [deve] fogir [fugir] a demaziada altura nos reparos ${ }^{93}$, não se infere dahi que seja demaziada a que passar de 18 pes Rinthlandicos [5,56m], que estabelece por ultimo termo inviolavel, e que seja tão insofrivel absurdo o excedela que a troco de nelle não incorrer, queyra expor a gente descuberta á mortandade que se lhe póde fazer do padrasto ${ }^{94}$ exterior: pello que neste cazo se póde e deve levantar o reparo athe 25 pés Portuguezes [8,25m] como logo diremos sem contrahir a nota de excesso; e nem pello alterar se devem deyxar de fazer os cavaleyros contra o padrasto dominante quando se não possa ganhar com alguma obra exterior,

\footnotetext{
${ }^{91}$ Através desta conversão é que observamos ter Vellozo cometido um pequeno equívoco em passagem anterior dizendo ser o pé Rinthlândico ligeiramente maior em vez de menor. Neste parágrafo ao fazer as conversões utilizando valores da tabela de Serrão encontramos resultados corretos.

${ }^{92} \mathrm{O}$ autor, em geral, escreve Fritach em outras partes do texto.

${ }^{93}$ Por este motivo, muitos engenheiros militares que serviram na Praça de Salvador condenavam a bateria do Palácio, que ficava na atual Praça Municipal, pela sua cota excessivamente elevada, dizendo ser uma defesa inútil.

${ }^{94}$ Como define Azevedo Fortes (Vol. II, Liv. $1^{\circ}$, p. 19), padrasto ordinário se chama qualquer oiteiro vizinho à praça, do qual póde ser batida com Artelharia.
} 
como se dirá adiante quando dellas se tratar; porque se o reparo se não altear neste cazo ficando descuberto ao padrasto dominante, incorreremos nos inconvenientes referidos contra os reparos bayxos, e assim fogindo de hum inconveniente dariamos em outro.

Mas passando as opinioens de outros AA [autores] sobre a dita altura dos reparos, Goldman liv. $2^{\circ}$ prop. 15 faz tambem a mayor altura de 18 pes $[5,94 \mathrm{~m}]$ como Fritach, e Dogen, que todos seguem o modo Holandez em que por serem ordinariamente as fortificações de terra, e a campanha raza basta esta altura; nem he facil que a terra se sustente bem subindo a mayor altura.

Barleduc liv. $1^{\circ}$ cap 6 quer que a altura do reparo entrando tambem a do parapeyto seja de 25 pés regios de França [8,0m], e porque faz o dito parapeyto pella parte interior alto de 8 a 9 pés [2,56 a 2,88m] com duas ou tres banquetas, dizendo que pella parte exterior será mais bayxo sem determinar altura certa, se se lhe der dous pés menos que a altura interior ficará a exterior do parapeyto de 6 ou 7 [1,92 ou 2,24m], os quais tirados dos ditos 25 [8,0m] ficará sendo a do reparo de 18 ou 19 pés regios [5,76 ou 6,08m] com pouca differença de Fritach, Dogen, e Goldman ${ }^{95}$.

Sardi na pratica da Corona ${ }^{96}$ pag. 160 o faz alto de 30 pés Geometricos $[8,34 \mathrm{~m}]$, e o mesmo repete outra vez na Architectura liv. $2^{\circ} \mathrm{Cap}^{\circ} 4^{\circ}$ pag. 54 .

Medina Barba no Exame $^{97}$ pagina 31 o faz de 20 pés geometricos [5,56m]: Rochas liv. $2^{\circ}$ pagina 392 a quem segue Vilhegas faz a dita altura de 15 pes Geometricos $[4,17 \mathrm{~m}]$.

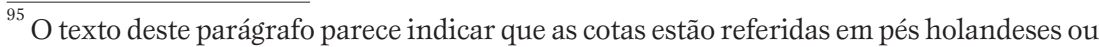
Rinthlândicos e em virtude disto adotamos na conversão o valor de $0,31 \mathrm{~m}$.

${ }^{96}$ Refere-se ao texto de Sardi: Corona imperiale dell'architettura militare divisa in due trattati. Il primo contiene la teórica. Il secondo la pratica. Venecia: Barezzo Barezzi, 1618.

${ }^{97}$ Está se referindo ao texto de Medina Barba: Esamen de fortificación editado em Madrid em 1599.
} 
Henrique Hondio ${ }^{98}$ vay quazi com Fritach, Dogen, e Goldman, fazendo no quadrado o reparo alto de 14 pés $[4,62 \mathrm{~m}]$; no pentagono de 15 [4,17m], e nas mais figuras de 18 [5,00m], em que pára pella mayor altura.

Bonajuto Lorine liv. $1^{\circ}$ pag. 24 asigna ao reparo da cortina 4 passos Venezianos $[7,44 \mathrm{~m}]$, ou 24 pés Rintlandicos [sic] $[7,42 \mathrm{~m}]^{99}$, e no mesmo liv. $1^{\circ}$ pag. 82 asigna 10 braças [?] ou 20 pés [?] ${ }^{100}$, mas ao reparo do baluarte asigna 5 ou 6 passos, que são 30 ou 36 pés[?] ${ }^{101}$, porque faz mais altos os baluartes que as cortinas, como fazião alguns dos antigos.

O Conde de Pagan faz o reparo alto principiando do fundo do fosso 6 toezas, e porque asigna tres de profundidade ao fosso, resta ao reparo de alto sobre o livel da campanha outras tres toezas $[5,98 \mathrm{~m}]$, ou 18 pés regios $[5,98 \mathrm{~m}]^{102}$.

Outros trazem outras medidas, que ou vem a coincidir, ou a cahir entre as sobreditas, o que tudo se entende na mayor praça real.

De tudo o dito se colhe que fazem os sobreditos auctores a altura do reparo de 18 athe 27 pes Rintlandicos [sic] [5,562 até 8,343m],

\footnotetext{
${ }^{98}$ Henrik Hondius (de Hondt) foi um destacado tratadista holandês que viveu entre 1573 e 1650. A primeira edição holandesa do seu texto saiu em 1624, mas a edição francesa mais difundida foi de 1625 intitulada: Description et breve declation des regles generales de la fortification. The Hague: Henrik Rondius, 1625.

${ }^{99}$ Considerando o passo veneziano de $1,86 \mathrm{~m}$ e o pé Rintlândico de $0,309 \mathrm{~m}$.

${ }^{100} \mathrm{O}$ autor não facilita muito o entendimento quando cita unidades de medidas de procedências diversas e de valores diversos sem especificar com clareza em todos os casos. Neste, por exemplo, os 24 passos venezianos equivalem aos 24 pés Rinthlândicos, mas, logo em seguida, refere-se a 10 braças ou 20 pés sem fazer referência à origem da medida exigindo-nos um exercício de exegese. Não podem ser medidas portuguesas, porque 10 braças são $22 \mathrm{~m}$ e 20 pés $6,6 \mathrm{~m}$ onde não aparece a mínima equivalência. A hipótese mais provável é que seja o braço veneziano, com o valor de $0,683 \mathrm{~m}$ e o pé, também veneziano, com $0,34 \mathrm{~m}$, o que, nesta caso, dará equivalência correspondente a $6,8 \mathrm{~m}$.

${ }^{101}$ Esta correspondência também não fica clara porque não foi explicitada a origem da unidade empregada.

${ }^{102}$ Considerando que se trata de medida portuguesa onde 1 toeza $=6$ pés.
} 
inclinandose os mais delles antes ao menor que ao mayor dos ditos termos, pellas razões assima referidas, excepto Rochas e Vilhegas, que a fazem de 15 pés Geometricos $[4,17 \mathrm{~m}]$, que he termo muyto limitado.

Nesta variedade tomamos 15 ou 20 pés Portuguezes $[4,95 \mathrm{~m}$ ou $6,6 \mathrm{~m}$ ] sobre o livel da campanha raza, porque assim cobre o reparo bastantemente os edificios, e não se póde o inimigo amparar desta altura, nem facilmente póde ser escalado, a juntandose a profundidade do fosso: porem no cazo que que [sic] de fora haja algum padrasto, ou va o terreno sobindo se poderá altear mais o reparo 4 ou 5 pes [1,32 ou $1,65 \mathrm{~m}$ ] ficando de 24 ou 25 [7,92 ou 8,25m], como tambem neste cazo póde ser necessario altear a estrada encuberta, e seu parapeyto, para que este se possa descobrir da praça pello contrario quando o reparo for fundado sobre alguma meya ladeyra, e que o terreno deça para a parte da campanha, como he na nossa praça de Estremôs em todo o bayro de Sam Tiago; então será escuzada tanta altura, e sera melhor profundar antes o fosso para com sua altura ater o reparo; e porque não se poderá em semelhantes sitios accommodar dentro tanta terra quanta sahir do fosso, se deytará muyta parte della para fora, para a parte da campanha, que servirá para que a explanada não fique tão inclinada.

\section{$\operatorname{Cap}^{\circ} 3^{\circ}$}

\section{DA GROSSURA DOS REPAROS.}

A grossura dos reparos não deve ser demaziadamente grande, por cauza da grande despeza que faria, nem tão pouco deve de ser muyto pequena, a fim de que não seja fraco para rezistir as baterias do inimigo. 
$\mathrm{Na} 1^{\mathrm{a}}$ parte Ignografica, nos governamos e houvemos respeyto para determinar os comprimentos das linhas ao tiro de mosquete; mas agora respeytaremos somente aos tiros do canhão; e como a principal defença contra elle seja o mesmo canhão oppondo ás baterias do inimigo outras baterias deve o reparo ser capaz de nelle se plantarem; pello que a grocura [sic] dos reparos se rege comummente pella que embebe o parapeyto, e a artelheria montada em suas carretas, e pello espaço que disparada recua.

E porque conforme Dogen pag. 87, e Fritach pagina 143 hum canhão montado em seu reparo occupa 18 pés [5,94m], recua 10 ou 12 [3,30m ou $3,96 \mathrm{~m}]$ que fazem $30^{103}$ [9,90m] será necessaria a esta grocura [sic] na parte superior do terrapleno de mais do que occupa o parapeyto, que se este for de 24 pés [7,92m] (como o fazem os Holandezes) vem a montar 54 pés $[17,82 \mathrm{~m}]$ toda a largura superior do reparo reprezentada na linha B7.

A largura inferior AG será tanto mais quanto forem as bazes das escarpas exterior G5, e a interior AC, a saber esta outro tanto como a altura CB, do reparo ao menos, para que os soldados, e moradores possão comodamente subir por toda a parte; a exterior G5 não he sempre certa, porque pende [depende] da qualidade da materia de que he revestido o reparo, que se for so de terra alguns The asignão a metade de sua altura, o que seguem Fritach, e Dogen; outros the dão os $2 / 3$, e ainda outros o fazem igual a dita altura, o que tambem pende [depende] da diversidade das terras de que he

\footnotetext{
${ }^{103}$ O autor não deixa claro se estas medidas foram fornecidas já transformadas em pés portugueses ou se em pés Rinthlândicos, em geral utilizados pelos autores holandeses. Se em pés portugueses os trinta indicados correspondem a $9,90 \mathrm{~m}$ que é o espaço que se necessita para fazer operar uma peça de artilharia. As velhas fortalezas nos dias atuais quando apresentam um espaço mais reduzido é porque a plataforma original foi ocupada por construções posteriores, principalmente quando estas fortalezas foram transformadas em quartéis, como são os casos dos fortes do Barbalho e de S. Pedro, em Salvador.
} 
feyto, mas sendo de pedra e cal bastará que seja ao quinto da altura como diremos adiante; e porque suppuzemos a altura de 20 pés Portuguezes [6,6m], a largura superior de 54 [17,82m], será a inferior nos reparos de terra de 84 ou 86 [27,72m ou 28,38m]; e nos revestidos de pedra e cal será de 78 [25,74m].

Mas porque a terra que sahir do fosso póde ser mais que a que embeber este reparo, principalmente nos que forem revestidos de muralhas, por haver de sahir alguma terra dos alicerces, e as mesmas muralhas occuparem parte do corpo do reparo, se fará este alguns pés mais groço, e ficará melhor para os effeytos apontados, como tambem para haver mayor praça para se assentarem cavaleyros no cazo que os haja, que foy o motivo que obrigou a alguns AA [autores] a determinar larguissimos os terraplenos, e quando não haja cavaleyros se hirão enchendo os baluartes com a dita terra que sobejar, porque (conforme diremos adiante) serão melhores os baluartes cheyos que vazios.

Fritach e Dogen com outros, varião as ditas grossuras, como tambem a altura dos reparos, conforme o numero dos lados da figura, por exemplo em hum pentagono a fazem menor que em hum exagono, e nesta figura menor que em hum eptagono, e assim por diante, porquanto dizem que será batido com menor numero de canhões, poys o inimigo vem com menos força a sitiar hu'a praça menor, do que vem contra hu'a mayor, porque a força do exercito expugnante se proporciona com a força da praça expugnada. A isto diz Ville liv. $1^{\circ} \mathrm{Cap}^{\circ} 30$ que será necessario que os da praça fação convenção com o inimigo para que não traga mais artelheria que aquella a que bem puderem rezistir os reparos da praça feytos em menos conta; e que he couza redicula imaginar que o expugnador haja de proporcionar as suas forças com as da praça, quando puder vir com muyta mais ventagem. 
Erard de Barleduc suppoem que o menor exercito vem armado com 12 canhões, e monições para 12000 tiros, os quais diz podem penetrar com roina quazi 12 toezas [23,76m], e por tanto quer que o reparo se faça ao menos de 13 toezas [25,74m], ou 78 pés $[25,74 \mathrm{~m}]$ na largura superior, e ainda diz que esta se aumentará se o inimigo vezinho for tão poderozo que possa pôr exercito armado de mayor numero de canhões.

Porem esta concideração he muyto methafizica, e falla nella por suppozição, nem se deve conseder que ainda que fosse tal a penetração com roina seria necessario aumentar a grossura do reparo, poys não podia cahir toda a terra aroinada no fosso, e nella se podião os defensores novamente reparar: pello que a largura que temos determinado he muyto suficiente, e so naquella parte em que se houverem de levantar cavaleyros será necessario aumentalla segundo se verá na sua descripção.

$$
\text { Cap. }^{\circ} 3 .^{\circ}
$$

\section{DOS PARAPEYTOS.}

Sobre os terraplenos, os quais são como ja se disse no Cap ${ }^{\circ}$ antecedente para rezistir a bateria, e para com sua altura cobrir o interior da praça se fazem os parapeytos para defender e cobrir os soldados, e canhões deputados á defença, e por isso se dizem parapeytos, porque reparão e defendem os peytos dos soldados, do qual effeyto se conhece claramente a sua muyta utilidade, e necessidade, a qual he tanta que se não poderia chamar perfeyta aquella fortaleza a que faltarem.

Alguns AA [autores] os fizerão de forma de hu'a quarta parte de circulo como se ve na figura 33 obrados de tijollo, discursando 
que por serem desta forma sendo batidos, resaltarião as ballas com pouco danno; mas he imaginação aeria, porque com a roina que as balas farião nos tijolos ninguem poderia estar detras delles á defença.

Bonajuto Lorine a quem segue o Capitão Antonio Sarti no quezito 23 quer que o parapeyto se faça alto da parte de fora pendendo para dentro da praça, porque dizem que assim reziste toda a grossura do parapeyto aos tiros da artelheria dos offensores, e que ficão assim melhor cubertos os defensores; e que tambem se conserva melhor do danno que lhe cauzão as chuvas, porque poderão estas escoar para a parte de dentro da praça onde farão menor danno do que farião correndo pella escarpa do parapeyto que suppoem ser de terra, a qual de sua natureza esta sugeyta a injuria que nella fazem as aguas; e para que os soldados possão ver e defender com a mosquetaria a estrada encuberta, e mais lugares de fóra faz sobre o dito parapeyto outro parapeytinho da altura de hum homem, detraz do qual atirem os mosqueteyros subindose sobre o parapeyto principal como se ve na figura 31 e para servir [Est.15] da artelheria abre canhoneyras pelas quais se possa servir.

O Cavaleyro Tensine aprova a mesma invensão do parapeyto pendente para dentro, excepto que reprova o parapeytinho sobre elle para atirarem os soldados, porque diz que se bem o mosqueteyro que estiver detraz do dito parapeytinho estará seguro do mosqueteyro inimigo que estiver de fora para o offender, com tudo não estará seguro dos tiros de artelheria, a qual atirando contra o dito parapeytinho em poucos tiros o desfará todo, pello que elle se serve de outro modo fazendo no dito parapeyto grosso não so canhoneyras para a artelheria, mas outras tambem differentes para a mosquetaria, as quais faz 15 pés $[4,95 \mathrm{~m}]$ distantes hu'a da outra, profundas 2 pés e meyo [0,825m], e compridas 16 [5,28m] deyxando 2 pés [0,66m] ultimos para fazer a 
fresta para o mosquete, porq' suppoem o parapeyto todo de 18 pés [5,94m] de largo, e diz que em cada hu'a das ditas aberturas poderão assistir dous soldados, que enquanto hum atirar, o outro carregará o mosquete, e o dará ao primeyro que dispara, os quais soldados se mudarão a miudo, e quer provar que por este modo ficão seguros os ditos mosqueteyros, porque diz que não podem ser offendidos mais que dos tiros perpendiculares da artelheria os quais não poderão offender mais que hum só mosqueteyro, oppondose aos mais tiros toda a grossura do parapeyto.

Mas nem de hum modo, nem de outro remedeão a falta que tem o parapeyto pendente para dentro, porque alem de por este modo poderem so disparar muy poucos mosqueteyros, nem ainda o farião com a segurança que se imagina, porque pella mesma fresta por onde disparão poderão ser offendidos dos mosqueteyros de fora, e com a artelheria brevemente será desfeyto o dito parapeyto naquellas partes onde fica fraco com as ditas aberturas, e assim ficará inutil para a defença que se pertende fazer; por onde sendo feyto naquella forma com declividade para dentro da praça servirá mais de fechar nella os deffensores, do que cauzarlhes ventagem para a defença, que he o que se procura.

O melhor modo he o comum de que o parapeyto seja mais alto da parte interior, e mais bayxo da exterior dando comodidade para que de toda a parte detraz delle se possa disparar: a duvida he quanta deve ser a altura interior como tambem a exterior, e de que grossura se deve fazer.

Antonio de Ville liv. $1^{\circ}$ Cap. ${ }^{\circ} 31 \mathrm{o}$ faz alto pella parte interior 4 pés [1,32m] athe 4 e $1 / 2$ [1,48m] o mais, por razão de poderem os canhões atirar livremente por sima delle, a que os Italianos chamão atirar a barba, escuzando canhoneyras as quais impugna no alto do reparo, porque diz que são perjudiciays [sic] á praça por muytas ra- 
zões: primeyramente havendo canhoneyras estará o inimigo certo dos lugares de donde os da praça poderão atirar com a artelheria, e poderá apontar a sua contra os tays lugares, a saber contra as canhoneyras e quando os de dentro atirarem ao mesmo tempo o farão os de fóra com que facilmente succedera que desmontarão a artelheria da praça.

Outra razão he que hum mesmo canhão não poderá atirar que acerte os pontos quando descobrir a abertura da canhoneyra, e aquellas q' forem feytas no extremo da cortina para defender a face do baluarte opposto será necessario que sejão muyto abertas, ou ficarão tão fracas por cauza da obliquidade, que o inimigo as desfara facilmente ficando então os de dentro sem parapeyto, como se póde ver na figura 34, onde as pontas A são tão fracas que não Est.17 poderão rezistir aos canhões, e ainda quando o inimigo lhe não atirasse so o sopro, e o fogo do canhão interior desfará as ditas pontas, com que abrira muyto a canhoneyra.

Alem de tudo isto diz que as canhoneyras são dificultozas de fazer, porque se ellas são de terra não se sustentão facilmente; se são revestidas de muralha os tiros do inimigo farão muyto danno aos artilheyros da praça por cauza das lascas, e salpico das pedras: se em lugar de muralha se revestirem de madeyra o fogo as queymará, pello que conclue que he melhor escuzalas e formar os parapeytos de modo que os canhões possão atirar por sima delles ${ }^{104}$,

\footnotetext{
${ }^{104}$ Pelo visto o autor é partidário dos parapeitos à barba. Esta polêmica da construção dos parapeitos arastou-se durante quase todo o tempo da arquitetura militar abaluartada. Para evitar a combustão da madeira ou a injúria que poderia provocar sobre os defensores o desprendimento de lascas de pedras ou tijolos dos parapeitos foi criada a chamada taipa militar uma espécie de construção em taipa como solo-cal com alta concentração do ligante (Vellozo descreve no Cap. 25 da $2^{\text {a }}$ parte do seu livro). Esta construção poderia absorver os projéteis. Nos parapeitos das fortalezas do Barbalho e de S. Perdro, o Mestre de Campo Engenheiro Miguel Pereira da Costa utilizou na construção dos parapeitos um massame de alta resistência feito de areia, cal e pó de tijolo, cuja composição já tivemos a oportunidade de examinar no NTPR.
} 
e por isso os faz somente altos os ditos 4 pés [1,32m], ou 4 e $1 / 2$ $[1,485 \mathrm{~m}]$ da parte interior, e da exterior tanto menor (o que não evita) q' a linha vizual va descobrir a raiz da contraescarpa ou quando os fossos forem estreytos, que se possa descobrir a estrada encuberta, ou ao menos a explanada. A grossura de 20 athe 25 pés [6,60m até $8,25 \mathrm{~m}]$; e para que os soldados possão atirar mais cubertos, no alto do parapeyto se serve de hu'a fileyra de barricas, ou meyas barricas, cheyas de terra, ou de sacos, ou sestos cheyos de terra dos quays se fará bom provimento nos armazens porque so se hão de servir delles em tempo de sitio, para os soldados poderem atirar pellas frestas que ficão entre hum e outro.

Francisco Tensine pello contrario louva as canhoneyras, e impugna os parapeytos á barba, porque diz que seria impossivel ao artilheyro ficando descuberto ajustar a pessa ao parapeyto sem que elle ficasse morto ou ferido da mosquetaria inimiga, e as mesmas pessas desmontadas; e que não basta o reparo dos sestões, porque estes sendo batidos pella frente, e pelos lados, brevemente serão desfeytos, por cuja cauza diz o mesmo Tensine que elle no sitio de Giuliers por cobrir a gente, e a artelheria mandou levantar o parapeyto mais dous pés $[0,66 \mathrm{~m}]$ com terra e fachina o qual era so de tres $[0,99 \mathrm{~m}]$, deyxandolhe suas canhoneyras nos lugares oportunos, e onde não houve lugar de o levantar fes cavar hum fossete por dentro ao pé delle para que os soldados ficassem mais bayxos, e assim cubertos, e defendidos ${ }^{105}$.

Nesta duvida mais me inclino eu tambem a artelheria jogue por canhoneyras porque o parapeyto se fes para cobrir e defender

\footnotetext{
${ }^{105}$ Este tipo de montagem para defender os operadores das peças de artilharia pode ser observado com desenho nas normas que o Conde de Lieppe fez para o exército português, no tempo de Pombal.
} 
os peytos dos homens como se disse no principio, logo he necessario que tenha tal altura que se consiga este fim mas sendo tal que os canhões possão atirar por sima delle he bayxo para cobrir os homens porque hum canhão fica so alto do chão tres pés $[0,99 \mathrm{~m}]$ quazi, o que he pouco para cobrir hum homem, e ainda pouco para cobrir as mesmas carretas as quais sendo ferradas são de altura de cinco pés $[1,65 \mathrm{~m}]$, de modo que ficão avançando dous pés $[0,66 \mathrm{~m}]$ por sima do parapeyto com que poderão ser vistas e quebradas com a artelheria de fóra, logo o parapeyto se não deve fazer tão bayxo.

Nem se póde dizer que pella altura dos terraplenos a artelheria com o recuar e o mesmo os soldados afastandose do parapeyto depoys de dispararem ficão logo cubertos, porque a isto se responde ao menos em quanto chegão a disparar terão perigo e melhor he que o posão fazer mais seguros tendo o parapeyto altura capaz de os cobrir.

Pello que será esta de seis pés $[1,98 \mathrm{~m}]$ pella parte interior como fazem os Holandezes geralmente com sua banqueta de hum pé $[0,33 \mathrm{~m}]$, ou pé e meyo [0,495m] de alto, e de largo tres ou tres e meyo $[0,99 \mathrm{~m}$ ou $1,155 \mathrm{~m}]$ com suas canhoneyras para jogar ${ }^{106}$ a artelheria, as quais podem estar feytas muytas e tapadas com terra, e no tempo do sitio abrirem-se as que forem necessarias, e ficarem tapadas as que não servirem por não enfraquecerem o parapeyto, e impedirem que os soldados possão estar detraz dellas estando abertas; so no extremo da cortina consedo que he melhor que a artelheria jogue a barba vista a dificuldade e muyta obliquidade

${ }^{106}$ Esta expressão antiga - jogar a artilharia - corresponde, atualmente, a atirar com a artilharia. 
das canhoneyras, e tambem dos cavaleyros, porque a altura destes faz que com menos que tenha o parapeyto se possão encobrir detraz delle os defensores, mas não nos flancos, nem tambem nas faces, sem que obstem as razões de Antonio de Ville, as quais so convencem contra as canhoneyras abertas no extremo da cortina junto do flanco para defender a face opposta porque nas mais senão dá a obliquidade que se da naquellas.

So se podia oppor contra todas o que diz na primeyra e segunda razão, mas em quanto á primeyra se responde que ainda que o inimigo sayba certamente de donde se the ha de atirar não he certo nem facil que logo emboque a canhoneyra e descavalque a pessa, e a troco deste risco fica o commodo da artelheria se asestar mais cuberta e a gente que a manea ${ }^{107}$, como tambem os soldados a somarem a dar a carga sobre a banqueta poys sendo o parapeyto bayxo ficão muyto expostos a mosquetaria inimiga.

A segunda se responde, que ainda que os lados da boca da canhoneyra não dem lugar a se descobrir tanto com a pessa quanto se poderia descobrir ficando a barba sobre o parapeyto com tudo se descobre todo o sitio necessario, e todas as do parapeyto dos flancos se podem apontar muy livremente a contraescarpa onde o inimigo poderá ter plantado a sua bateria alem de que nas fortalezas ha muytas pessoas das quays humas se derigem a hum sitio, outras a outro.

A forma em que se fazem as ditas canhoneyras diremos adiante em capitulo particular.

\footnotetext{
${ }^{107}$ Forma arcaica de manejar ou movimentar.
} 


\section{$\operatorname{Cap}^{\circ}{ }^{\circ} .^{\circ}$ \\ DA GOSSURA DOS PARAPEYTOS}

Proporcionão alguns AA [autores] a grossura do parapeyto conforme o numero dos lados da figura a saber que fazem

$\begin{array}{llllllll}\text { No } & 4 & 5 & 6 & 7 & 8 & 9 & \text { et. }^{\text {a }}\end{array}$

A largura superior.

$\begin{array}{lllllll}9 & 11 & 12 & 15 & 17 & 21 & \text { et. }^{\mathrm{a}}\end{array}$

A inferior.

$\begin{array}{lllllll}12 & 14 & 15 & 18 & 20 & 24 & \text { et. }^{\mathrm{a}}\end{array}$

Porem isto he arbitrariamente, e sem fundamento porque nenhu'a figura de sua natureza pede menos largura de parapeyto huma que outra e assim se no quadrado bastão 9 pés [2,97m], para que he no eneagono $21^{\mathrm{s}}$ [6,93m]. E se nesta figura são necessarios 21 [6,93m] como bastão no quadrado $9^{\mathrm{s}}[2,97 \mathrm{~m}]$. A razão que asignão não he bastante, a saber que o exercito expugnante não traz tanto poder e artelheria contra hu'a fortaleza quadrada como contra outra de mais lados e assim não he necessaria tanta grossura no quadrado como nas mais figuras porque ja se respondeu acerca dos terraplenos que isto valeria se o inimigo estivesse com nosco por este acordo.

Poderão dizer mais que hu'a figura pequena na qual he ordinariamente o quadrado não pode receber tanta grossura de parapeyto como outra figura mayor a respeyto do que as grossuras comem e estreytão as praças dos baluartes e huma figura mayor ficaria diminuta se se the não dessem tays grossuras que fossem capazes de fazer toda a rezistencia, o que tudo he verdade mas isto 
nasce da grandeza ou pequenhez do lado de cada figura, e não do numero delles; que se hu'a figura quadrada fosse de grandes lados poderia receber muyto mayor grossura de parapeyto do que se essa mesma figura fosse de pequenos lados; assim mesmo em hum pentagono de grandes lados se poderia accommodar mayor grossura que em outro pentagono ou exagono de pequenos lados; pello que pella grandeza deste he que se ha de governar a largura e não pello numero dos lados da figura.

Admitimos por tanto a grossura superior do parapeyto de 9 athe 21 pés [2,97m até $6,93 \mathrm{~m}$ ], conforme for a grandeza do lado da figura, a saber, no menor lado se faça de 9 pés [2,97m], e daqui se va crescendo athe 21 [6,93m] conforme forem crescendo os lados da figura, assim se ira engrossando o parapeyto quanto mais puder ser athe o dito termo, ou tambem engrossando mais onde se temer bateria, como nas faces e flancos e menos nas cortinas, conforme judiciozamente parecer ${ }^{108}$.

A altura exterior será tanto menos que a interior quanto for a quinta parte da largura, a saber, sendo esta de 21 pés [6,93m], e a altura interior $6[1,98 \mathrm{~m}]$ será a exterior de 1 e 4/5 [0,594m]; sendo a largura de 17 pés $[5,61 \mathrm{~m}]$ será a altura exterior de 2 e $3 / 5$ $[0,858 \mathrm{~m}]$, e a interior sempre certa de 6 pés $[1,98 \mathrm{~m}]$.

Nesta forma sem demaziada largura do fosso defronte da face se descobrirá toda a largura da estrada encuberta; porque seja a largura superior do parapeyto de 21 pés [6,93m], a differença das alturas interior, e exterior reprezentada na porção IO será de 4

\footnotetext{
${ }^{108}$ Este princípio de engrossar "judiciosamente" os parapeitos na direção onde se poderia temer bateria pode ser encontrado na construção das fortalezas do Barbalho e de Santo Antônio Além do Carmo, pois os parapeitos do Norte e do Oeste são claramente mais espessos, justamente nas direções onde se poderia esperar o ataque.
} 
e 1/5 [1,58m], logo continuando a linha IH athe Z, porquanto são Fig. 32 Est. $16^{a}$ equiangulos os triangulos IOH, IXZ, serão proporcionays IO para $\mathrm{OH}$, como IX para XZ; mas as tres primeyras são sabidas IO de $4 \mathrm{e}$ $1 / 5$ [1,58m], OH de $21[6,93 \mathrm{~m}]$ e IX de 26 [8,58m], a saber toda a altura interior do parapeyto IR de 6 [1,98m] com RX altura do terrapleno de $20[6,6 \mathrm{~m}]$ que he o mayor termo asignado no Cap. ${ }^{\circ}$ 2. ${ }^{\circ}$ por tanto sahirá XZ de $130[42,9 \mathrm{~m}]$, de que tirando XP de 25 [8,25m] se o parapeyto for emediato sobre a muralha restão 105 [34,65m] na linha PZ, e fazendo o fosso desta largura que não he demaziada (como diremos adiante) se descobrirá do alto da face toda a estrada encuberta e se houver estrada de rondas no alto da muralha ainda ficará menor a linha FZ, e descobrirá melhor a dita estrada encuberta; e assim mesmo dos flancos se descobrirá mais de a metade de toda a cortina no plano do fosso; porque suppondo este de 18 pés $[5,94 \mathrm{~m}]$ de fundo que he bastantissimo, o terrapleno os mesmos 20 pés $[6,6 \mathrm{~m}]$, o parapeyto de 6 [1,98m] he toda a linha IXY de 44 [14,52m]; supponhase o mesmo perfil da fig. 32 como se fora cortado em hum dos flancos, logo dizendo se IO de 4 e 1/5 [1,58m] dá $\mathrm{OH}$ de 21 [6,93m], IY de 44 [14,52m] dará 220 [72,6m] pella linha YK, de que tirando YB de 121 [39,93m] resta BK de 99 $[32,67 \mathrm{~m}]$; e porque no Cap. ${ }^{\circ} 14^{\circ}$ da $1^{\text {a }}$ parte se permitio a cortina nas grandes praças athe 500 [165m]: logo dos flancos com toda aquella altura de terrapleno no parapeyto e fosso ainda se descobre mais de a metade da cortina na sua raiz como se propôs.

A largura inferior ou baze do parapeyto será tanto mais que a superior quanto for a metade de sua altura exterior e hum pé $[0,33 \mathrm{~m}]$ mais que somente deve ter pella parte interior, o que tudo se verá melhor no perfil. 
Resta somente determinar o lugar do parapeyto o ordinario he [Est.15] que se faz logo a face exterior da muralha como se ve na figura 31: porem nas praças grandes onde ha bastante largueza nas areas dos baluartes he melhor que o parapeyto se retire hum pouco para dentro, deyxando entre elle e a face exterior da muralha hum espaço de

[Est.16] 5 ou 6 pés [1,65 ou 1,98m] como se ve na figura 32, o qual servirá de estrada para as rondas fazendolhe seu parapeyto diante o qual costuma ser hum pano de tijolo para resguardo dos que nella andarem.

A sua utilidade se conhece da muyta necessidade que ha das ditas rondas em hu'a praça de guerra, e dos muytos proveytos que dellas se seguem, de que em outro lugar se dirá; serve tambem aquella estrada como de banqueta ao parapeyto, que he certo custará mais a desfazer ficando mais retirado da superficie exterior da muralha e se sustentará melhor ainda no cazo que caya algu'a parte delle.

Cap. $^{\circ} 5^{\circ}{ }^{\circ}$

DAS MURALHAS.

As muralhas formão a parte exterior do reparo e o sustentão; porem muytos AA [autores] com Antonio de Ville liv. $1^{\circ}$ Cap $^{\circ} 29$ as querem regeytar como inuteys para a defença e dizem que de qualquer materia que sejão feytas rezistem menos que a terra e que são mais depreça aroinadas pella bateria do inimigo: dizem que a sua roina e pedras enchem o fosso, e servem de subida para a brexa; dizem tambem que os pedaços e lascas das pedras fazem grande danno aos defensores; que as minas dentro das muralhas fazem mayor effeyto e danno que na terra em razão da mayor rezistencia que naquellas acha a polvora inflamada imitando nisto 
ao rayo que fas mayor effeyto onde acha mayor rezistencia como a experiencia ha mostrado.

Em abono dos reparos de terra diz Dogen liv. ${ }^{\circ} 1^{\circ} \mathrm{Cap}^{\circ} 10^{\circ}$ que posto que batidos e começados a aroinar se reparão facilmente ainda entre os perigos do conflicto, concertandose de noute para servirem no dia seguinte de novo impedimento ao inimigo, e persentindose nelles mina póde mais facilmente ser cortada, e aventada pellos defensores q. ${ }^{\text {do }}$ os muros são terreos, do que quando são revestidos de muralha de pedra e cal.

Diz mais que as ballas que dão na terra não fazem mais que entrar sem cauzar lascas e pedaços q' firão a gente, nem fazerem tanta roina como nas muralhas, e que as minas cauzão menores effeytos, as quais razões confirmão com o exemplo das praças de Holanda, onde não costumão revestir as fortificações com paredes de pedra, posto que naquelle paiz a haja em abundancia, como testemunha Fritach liv. $1^{\circ}$ Cap $^{\circ} 9$ pag. 28.

Porem sem embargo destas razões se póde dizer que não se deve absolutamente preferir o reparo de terra nua ao revestido de muralha, porq' este impede grandemente os assaltos repentinos, ou declarados os quais os inimigos não poderão executar senão por escadas, cujo aparato he muy grande, e seu uso incerto; juntamente impede que a guarnição e payzanos possão sahir de noyte $\mathrm{q}^{\text {do }}$ haja algum mal intencionado: e sobre tudo he obra firme e duravel, o que não tem a terra que he necessario andala reparando cada dia e nem com tudo isso se conserva.

Quanto as razões sobreditas, a primeyra q' de qualquer materia que sejão feytas as muralhas rezistem menos que a terra se responde, ou póde responder, negando que rezistão menos se os muros forem bem groços, e com bastante escarpa, e apoyados com a terra de encosto. 
Quanto a segunda, a roina e pedras dos muros enchem o fosso se responde que he o mesmo nos reparos de terra, e com mayor razão, porque como necessariamente para se sustentarem hão de ter mayor escarpa, esta faz que com menos roina se facelite a sobida ${ }^{109}$.

A terceyra razão que os pedaços e lascas das pedras fazem danno aos defensores, isto se evita se os muros não subirem athe o alto, mas sobre elles se assentar o parapeyto so de terra e ainda que a muralha suba athe sima, a terra que se lhe encosta por detraz mais alta pella parte de dentro para formar o parapeyto basta para livrar deste perigo ${ }^{110}$.

A quarta que as minas fazem mayor effeyto dentro das muralhas de pedra se responde que tambem são mais custozas de fazer as ditas minas, não estando as muralhas como a terra sugeytas a serem cavadas com pá e enchada: e quanto a poder a mina mais facilmente ser cortada e aventada, tambem havendo muralhas se podem melhor fazer contraminas ${ }^{111}$ pellas quais se consiga este effeyto.

Que os reparos de terra sendo batidos facilmente se reparão de noyte, o mesmo póde ser nos revestidos de muralhas: e se os vales de terra se reparão de noyte sobre as mesmas ruinas, hindo

\footnotetext{
${ }^{109}$ Neste capítulo Vellozo defende claramente as muralhas de pedra e cal argumentando, contra os teóricos holandeses. Uma das razões que apresenta no parágrafo é que o ângulo de talude é mais acentuado com o uso da cortina de pedra dificultando ser escalada pelo inimigo.

${ }^{110}$ Para evitar o inconveniente das lascas de pedra que voam contra os defensores, Vellozo está propondo o parapeito com taipa que, como sabemos, era uma taipa especial estabilizada com cal e, conseqüentemente, de grande resistência e durabilidade.

${ }^{111}$ Galerias feitas pelos defensores para ouvir e atalhar as escavação de minas sob as fortificações, uma técnica que vem da remota antiguidade, mas que se tornou muito comum e mais destruidora quando foram descobertos e empregados os explosivos, no caso, a pólvora.
} 
formando e ajuntando nova terra para servir de novo reparo e parapeyto, detraz do qual se defendão, isto mesmo tambem póde fazerse sobre as ruinas das paredes, que se não diz que estas se não reedifiquem de noyte, nem de dia, durando o sitio.

Quanto ao exemplo das praças de Holanda que são so de terra as suas muralhas, se responde, que nem so em Holanda ha praças fortificadas, muytas em outras muytas partes o são, e melhor que em Holanda, e são revestidas de muralhas, e não farião os Principes este dispendio se não fora necessario, e util.

Poderão replicar que se fazem este gasto das muralhas he porque he necessario para o sustento das terras, e não porque seja melhor para a guerra, mas para o tempo desta he que se necessita mais de que a fortificação se sustente e tenha em pé logo para o tempo da guerra he que são necessarias as paredes: pello que havendo cabedal e tempo não he gasto escuzado o revestir as fortificações, principalmente entre nós onde ha pouco cuydado das couzas publicas ${ }^{112}$.

A cerca da altura das muralhas Bonajuto Lorine e outros dos antigos a fazem somente alta quanto he a altura do fosso e dahi para sima fazem o reparo de terra, deyxando entre elle e a muralha huma estrada para as rondas vigiarem.

Outros affeyçoados a opinião dos que dizem que as muralhas não servem de mayor rezistencia, e por outra parte vendo quam mal sem ellas os terraplenos se sustentão, seguem hum meyo que he fazerem-nas somente altas athe o meyo dos terraplenos, e dahi deyxando hu'a estrada de 6 athe 10 pés [1,98 até 3,3m] de largo com hum parapeyto de taypa ou tijolo bem argamaçado detraz do qual possa

${ }^{112}$ Observe-se que este hábito é coisa muito antiga entre nós! 
jogar a mosquetaria e por ficar mais bayxo defenderá melhor o fosso, levantão o resto do reparo só de terra, sobre o qual formão outro parapeyto tal que a artelheria possa jogar sobre elle por toda a parte, ficando o dito parapeyto como cavaleyro em roda de toda a fortificaEst. 17 ção, como se ve na figura 35, em que BC reprezenta a muralha desde o fundo do fosso athe 10 ou 12 pés [3,3 ou $3,96 \mathrm{~m}$ ] sobre o plano do terreno natural; $\mathrm{G}$ mostra a estrada de 6 athe 10 pés [1,98 até 3,30m] de largo. $\mathrm{X}$ o parapeyto para os mosqueteyros. $\mathrm{Z}$ o resto do reparo sobre esta estrada, com seu parapeyto da grossura ordinaria detraz do qual se alojará a artelheria.

Este modo não me parece máo, so necessita de mais largura a dita estrada, porque as roinas do cavaleyro não embaracem a assistencia dos mosqueteyros, e tambem o seu parapeyto deve ser mais largo capaz de rezistir a artelheria, e nos angulos flanqueados necessita de hu'a groça traveça porque de fora se não pudesse enfiar a dita estrada.

O modo comum he que as muralhas subão tão altas como o terrapleno, mas ainda nisto ha variedade acerca do cordão, porque huns o poem no alto da muralha outros aos dous terços, outros aos tres quartos de sua altura, cada hum conforme quer caprichar; nesta variedade, eu o poria no alto immediatamente por baixo do parapeyto, porque me parece ficão assim as muralhas parecendo mais alterozas e ficão tambem mais fortes sobindo a escarpa athe asima, e serve tambem ali o dito cordão para tornejar com as bazes das guaritas, o que me parece melhor do que começar o pião para a baze da guarita sobre o cordão como he necessario quando este fica mais bayxo ${ }^{113}$ : porem nisto vay pouco, so havendo estrada de

\footnotetext{
${ }^{113}$ Observar as preocupações estéticas da aplicação da modenatura, no caso o cordão ou bocel. Este tema é, também, bastante analizado no tratado de Serrão Pimentel.
} 
rondas no alto do reparo como se disse no $\mathrm{Cap}^{\circ} 4 .^{\circ}$, porquanto a altura exterior do parapeyto he muy pouca será necessario que o plano da dita estrada fique dous pés $[0,66 \mathrm{~m}]$ mais bayxo do que a altura do terrapleno, e assim mesmo o cordão ficará no plano da dita estrada, a qual seria bom que fosse empedrada de secho [seixo] miudo como são as calçadas das ruas, e que tenha algu'a correnteza para escoar as aguas que ali forçozamente se hão de ajuntar e correr dos parapeytos, as quais se lhe dará sahida por canos de pedra que se podem fazer nos angulos dos baluartes por bayxo do cordão de hu'a e outra parte das guaritas, e tambem no meyo das cortinas; mas o parapeyto desta estrada como he so para resguardo de que os soldados de noyte não cayão no fosso, basta que seja de hu'a meya parede de palmo e meyo [0,33m] de groço athe dous palmos $[0,44 \mathrm{~m}]$, e a altura será de 4 pés $[1,32 \mathrm{~m}]$.

Outra duvida he sobre as grossuras das muralhas no cazo que se hajão de fazer, porque huns querem que se fação delgadas, e de tanta grossura somente quanta baste a conservar o reparo em pé, e a que a terra se não desfaça e escorregue com as chuvas, e inclemencias do tempo: porq' dizem que fazendose a muralha delgada, mais depreça se segura o reparo acabandose a dita muralha em menos tempo, e que tambem se dispende menos cabedal que na groça: e outra razão he que sendo batida a muralha pello inimigo e cahindo encherá menos o fosso, e por conseguinte fara menor subida do que faria se fosse grosso, pello que dizem que se o reparo de terra for bem feyto, e com ordem, nos devemos mais confiar na sua grossura que na da muralha, a qual neste cazo querem fazer encostada ao mesmo terrapleno, sem que fique aplumo pella parte de dentro, porque no cazo de cahir sendo batida fique a terra com sua escarpa capaz de per si so se poder sustentar. 
Outros pello contrario aseverão que isto não convem, e que as muralhas se devem fazer reays, e groças, capazes de poder rezistir a qualquer contraste, dizem que havendo de se fortificar se não póde escuzar o muyto custo, e que assim quem se rezolver a fortificar hu'a praça deve procurar de o fazer de modo que a fortificação dure (se puder ser eternamente) mas fazendo a muralha delgada não se póde esperar que dure muyto tempo porque se as obras de muralha grossisima, e cubertas, padecem com as injurias do tempo, das que forem delgadas se não poderá esperar que durem muyto.

Dizem mais que em todas as fortificações são muyto necessarias as contraminas, e sortidas as quais se não podem bem fazer se a muralha não he groça. Estas são as razões que por hu'a e outra parte se alegão, das quais as segundas são hoje as seguidas por todos universalmente; porque $\mathrm{q}^{\text {to }}$ á presteza de fazer a obra se remedea com mayor numero de operarios; e quanto ao enchimento do fosso não he de grande concideração a grossura da muralha de dous pés $[0,66 \mathrm{~m}]$ mais ou menos: que se deva attender á grande despeza isto se não póde negar, mas he quando esta for superflua; porem faltar á bondade da obra com o pertexto [sic] de poupar gastos, isto se não deve admitir principalmente quando a materia he sugeyto de fortificar e singir cidades he so obra de Principes, aos quais nunca convem o vicio da avareza, e a nobreza da obra pede que seja feyta com grandeza ${ }^{114}$.

Porem a grossura não se faz a mesma em toda a altura da muralha, mas face mais groça na parte inferior hindo adelgaçando assim como vay sobindo, o que se chama feyta a escarpa, e fica

\footnotetext{
${ }^{114}$ Faz, de certa forma, uma exortação ao Rei de Portugal para fazer fortificações decentes, pois os soberanos portugueses mostravam-se sempre avaros nos investimentos para fortificar os seus domínios especialmente as suas colônias.
} 
formando hum triangulo rectangulo cuja hipotenuza reprezenta a escarpa hum lado a altura outro a baze da muralha a qual dizem alguns AA [autores] que se faz assim porque as ballas dando nella obliquamente não fassão tanto effeyto, como farião se a muralha fosse aplumo pella parte de fóra; mas a razão verdadeyra he porque como a muralha ha de sustentar em bayxo mais pezo do que em sima necessitava tambem em bayxo de mais grossura.

Na provincia de Alem Tejo em todas as fortificações que nella se fabricarão se fizerão as muralhas que acabassem no alto em quatro pés de groço $[1,32 \mathrm{~m}]$, e na baze contada do plano do fosso tanto mais quanto for a quinta parte da altura athe a raiz do cordão, e isto he hoje o mais comum, e so quando os materiays com que se fabricar a muralha forem fracos, e o terrapleno for pouco pinque que se não sustente a mayor parte em si proprio, se póde admitir a escarpa ao quarto, e o mais ao terço da altura da muralha.

Tambem se poderá admitir ao sexto, e ao setimo ${ }^{115}$ no cazo da muralha haver de subir a pouca altura e o terrapleno haver de pezar pouco sobre ella, e tambem segundo a diversidade do terreno em que se abrem alicerces.

Antonio de Ville pergunta qual se deve fazer primeyro se as muralhas, se os terraplenos e diz que por seu votto as muralhas, fundado em que fazendose estas primeyro com seos contrafortes se accomodará entre elles a terra mais bem assentada e unida, e logo que tambem se botará a melhor terra junto das muralhas, e outros lugares mais perto das baterias e a peyor mais longe.

\footnotetext{
${ }^{115}$ Para os que não estão familiarizados com a nomenclatura esclarecemos que estas expressões definem o que chamamos de arrasto da muralha na relação de 1:6 e 1:7 sistema que ainda usamos atualmente, inclusive na definição da pendência dos telhados. Estes números em porcentagem de inclinação das muralhas correspondem a $16,66 \%$ e $14,28 \%$, respectivamente, em relação à vertical.
} 
Pello contrario em outras partes se fazem primeyro os terraplenos, com o pertexto [sic] de que assim carregarião menos as muralhas sendo estas feytas depoys delles assentados: por rezolução digo que no tempo da guerra he mais acertado obrar primeyro os terraplenos, porque estes podem servir sem as muralhas, e estas não servem sem os terraplenos porem no sosego da paz importa de pouco que humas ou outras se obrem primeyro antes he mais facil que se vão obrando juntamente os terraplenos assim como vão sobindo as muralhas e isto he o que se faz ordinariamente: dos alicerces, escolha dos materiays para a fabrica das muralhas e modo de obrar os terraplenos diremos no fim desta segunda parte.

\section{$\operatorname{Cap}^{\circ}{ }^{6} .^{\circ}$ \\ DOS CAVALEYROS}

São os cavaleyros huns terrenos mais levantados sobre os reparos da praça os quais são assim chamados por semelhança da ventagem [vantagem] que tem hum homem a cavallo para descobrir mais longe, que outro que esta a pé; assim mesmo estando sobre os cavaleyros se descobre e offende mais ao longe com a artelheria ao inimigo, obrigando-o a acamparse mais distante, e a começar de lá os aproxes, com mais trabalho e desperdicio de tempo, sendolhe tambem necessario fazellos mais fundos, e as trincheyras, reductos, baterias, e outras obras mais altas para se poder cobrir.

Servem tambem para se cobrirem alguns lugares enfiados, e opporse a outros exteriores mais elevados; assim mesmo defendem grandemente o plano dos baluartes, como muytas vezes tem 
succedido, sendo o inimigo desalojado dos postos que nelles havia ganhado, pella offença que se lhe fazia dos cavaleyros.

Não falta quem os reprove com razões pouco fundamentays: porque dizem que por ficarem retirados não podem bem expelir ao inimigo; que são deficeis de fabricar por serem levantados sobre os reparos, e que em razão de sua altura cauzão grande despeza que são alvo a bateria do inimigo que tanto que este se lhe aproxima não ficão ja servindo por se não poder apontar a artelheria para bayxo sem se descobrir ou diminuirem-selhe em grande parte os seus parapeytos que embaração as cortaduras e havendo-os o inimigo rendido se serve delles com grande ventagem contra a praça.

Aponta todas estas razões Antonio de Ville a que se responde, quanto a primeyra, que são de pouco effeyto para expelir o inimigo por ficarem retirados do parapeyto do reparo, que este defeyto se supre com sua altura, poys por respeyto della descobrem muyto ainda que estejão retirados; e quanto á segunda, que a dificuldade de sua fabrica não he tão grande que senão possa executar, como se ha feyto em muytas praças; nem o que he para mayor segurança, e ventagem contra o inimigo se deve regeytar por respeyto do trabalho e despeza.

Em quanto a se dizer que são emprego dos tiros contrarios se responde, que sejão ou não sejão, he necessario ao inimigo levantar suas baterias mais altas recebendo no entretanto grandissimo danno, mayor do que elle fará contra os cavaleyros, por serem estes obrados com vagar e perfeyção, e pello contrario as trincheyras do inimigo serem feytas com muyta seleridade em occazião de sitio.

O dizerem tambem que são de pouco effeyto quando o inimigo se lhe aproxima se responde, que ao menos sempre se descobre delles a area dos baluartes proximos, o que não he tão pouco. 
Em quanto ao dizerem que impedem as cortaduras se responde que os cavaleyros situados na cortina (que he o seu proprio lugar) não impedem as cortaduras, porque estas se fazem nos baluartes, por onde o inimigo comummente intenta ganhar a praça como por lugar mais commodo sem nunca prudentemente o intentar pellas cortinas segundo se dirá no ataque das praças.

E no que toca a dizerem que havendo o inimigo rendido algum cavaleyro se serve delle com ventagem contra a praça se responde que se esta razão he valida, não se fação tambem baluartes, porque rendido algum se póde o inimigo servir delle contra a praça; e se a tal razão não vale contra os baluartes, menos vale contra os cavaleyros, os quais o inimigo não póde ganhar antes dos baluartes, e emquanto os não ganhar sempre delles se lhe fará grande offença, por tanto os devemos julgar por uteys sem embargo das razões contrarias.

Resta dizer a sua forma, situação, e mais circunstancias, e supposto esta materia esteja bem tratada no Methodo Luzitanico parte $1^{\text {a }}$ secção $1^{\text {a }}$ Cap. ${ }^{\circ}$ 34. pag. 142 onde se podia ver, com tudo, como nem todos podem ter o dito Methodo, será percizo [sic] dizer a forma, e aonde se fabricão.

Alguns os fazem dentro do corpo do baluarte, o que se não deve admitir porque impedem totalmente as cortaduras, so em cazo de urgente necessidade para se oppor a algum padrasto.

Outros os fabricão sobre os angulos da espalda, e ainda neste lugar não são os melhores, porque não defendem mais que a area do baluarte proximo, e será forçozo fazer outro cavaleyro da outra parte o que he de grande custo.

Finalmente os que melhor os situão he no meyo das cortinas, porque assim conseguem o descortinar e defender as areas dos dous baluartes colaterays igualmente. 
A sua forma póde ser redonda, ouvada, quadrada, ou Est.18. ${ }^{a}$ porlongada [prolongada], como tudo mostra a figura 36, tenho por melhor esta ultima.

Costumão fabricarse afastados do parapeyto do reparo dez ou doze pés [3,30m ou 3,96m], o Engenheyro Portuguez liv. $2^{\circ}$ Cap ${ }^{\circ} 8$ pag. 130 quer que sejão apartados do parapeyto da cortina quatro braças e meya [9,90m], mas isto he demaziado, porque obriga a fazer os terraplenos das cortinas muyto largos, e o fosso por largo que seja não póde dar terra para tanto, e alem disso quanto mais retirados são os cavaleyros, mais depreça se cobre o inimigo dos seus tiros aproximandose a estrada encuberta. A frente se fará de 100 athe 150 pés [33m até $49,5 \mathrm{~m}$ ], conforme for o comprimento da cortina, e os lados serão de 55 athe 60 pés [18,15 até $19,8 \mathrm{~m}$ ], isto se entende na linha inferior que na superior sera tanto menos quanto forem as bazes das escarpas. Estes lados com a frente formarão angulos de 110 athe 120 graos o mais, conforme for o poligono fortificado hindo aumentandose de grao em grao, assim como tambem se vão aumentando os lados da figura, mas nunca se excederá o dito termo.

Pella parte interior se lhe fara hu'a rampa, ou sobida de 5 athe 6 pés [1,65 até $1,98 \mathrm{~m}$ ] de largo se for feyta de terra porque he força tenha em tal cazo sua escarpa interior; entre esta e a escarpa interior do reparo se deyxa outra estrada semelhante a que se deyxou entre a sua frente e o parapeyto do reparo.

A altura destes cavaleyros quer o dito Methodo Luzitanico que seja de 10 athe 14 pes [3,30 até 4,62m], e o Engenheyro Portuguez the asigna tres braças e meya $[7,70 \mathrm{~m}]$, em cujas medidas ha hu'a grande differença, e assim me parece de razão tomar o meyo entre ellas, e fazello alto de 16 athe 18 , pés [5,28 até $5,94 \mathrm{~m}$ ], salvo se a necessidade pedir mayor altura; o talud ou baze da escarpa 
exterior se fara igual a ametade [metade] de sua altura, e a escarpa interior se fará igual a altura do reparo.

O parapeyto do tal cavaleyro será de vinte athe 24 pés $[6,60 \mathrm{~m}$ até $7,92 \mathrm{~m}$ ] de largo na sua baze; sua altura interior será de 3 pés e $1 /$ 2 athe 5 palmos [1,15 até $1,10 \mathrm{~m}$ ], e a exterior será tanto menos de sorte que a linha vizual por sima do parapeyto va descobrir a estrada encuberta defronte do meyo da cortina, que he a mayor largura do fosso, ou ao menos se descubra toda a area de revelim sendo que ali o haja, e diz o mesmo Methodo que será melhor ficar sem altura exterior, fenecendo a sua linha superior no extremo da linha interior da lezira ${ }^{116}$ que se deyxou entre o cavaleyro e o parapeyto do reparo; a altura interior tambem costuma ter escarpa em razão da terra se sustentar melhor, e costuma ser esta de hum pe [0,33m] de baze.

E porque havendo de fazerse cavaleyros nas cortinas necessariamente deve ser nellas mais largo o reparo the asignamos de 75 athe 80 pés Portuguezes [24,75m até $26,4 \mathrm{~m}]$, que he bastante largura.

\author{
$\operatorname{Cap}^{\circ}{ }^{\circ} .^{\circ}$ \\ DOS FLANCOS CUBERTOS COM \\ ORILHÕES, OU ESPALDAS.
}

O que athe agora se explicou nos capitulos antecedentes acerca do perfil, toca mais particularmente ás faces e cortinas; mas os flancos como tão principays na fortificação segundo temos incul-

\footnotetext{
${ }^{116}$ Segundo definição de Serrão Pimentel: Margem, Lizira, ou Berma he uma margem de terra que se deixa entre o Parapeito da Falsabraga, \& o Fosso; mas como nòs não costumamos fazer Falsabraga, e sahem as muralhas de dentro do Fosso não se fazem estas Bermas salvo quando a muralha émuito alta se faz então nela, ou deixa húa Berma da mesma muralha para maior segurança, \& fortaleza da obra.
} 
cado no $\mathrm{Cap}^{\circ} 15^{\circ}$ da primeyra parte ignografica, necessitão ainda de outro cuydado, e arteficio para melhor cobrir a artelheria que nelles se poem, porque não seja vista de fóra the acrescentarão os orelhões, ou espaldas, e isto he o que ja dissemos no Cap ${ }^{\circ} 15$ que os flancos se diferenciavão segundo os accidentes exteriores em flancos cubertos, e descubertos.

Os Holandezes os não costumão fabricar fundandose em que os seus flancos rectos ficão bem cubertos com as obras exteriores que sempre fazem defronte das cortinas, que quazi sempre são tão fortes como a mesma praça, e cobrem de sorte aos flancos que não póde o inimigo batellos sem primeyro ganhar a obra exterior, e athe esse tempo se acha o flanco sem danno algum capaz de rebater ao inimigo: mas esta razão tambem padece suas objecções.

Supponha-se que o inimigo não póde descobrir a artelheria dos flancos por cauza das obras exteriores com que se acha cuberta, pella mesma razão a artelheria da praça não podera descobrir as baterias do inimigo; a razão natural esta persuadindo esta verdade, porque aquillo que eu não posso ver, tambem não posso delle ser visto; alem de que cauza hu'a grande ventagem [vantagem] ao inimigo o senhorear-se de hu'a destas obras exteriores, que commummente são firmes, solidas, e bem obradas, para nellas plantarem as suas batarias, e desfazerem as defenças da praça.

Mas como ja dissemos que as praças de Holanda não podem servir de exemplo, por não serem unicas na Europa, onde ha outras muytas, muy fortes e de grande reputação, e todos os modernos reconheção a utilidade dos orilhões poys se segue delles a ventagem de haver na praça dous, tres, quatro, e mais canhões, de tal modo cubertos que o inimigo os não póde desmontar, os quais estão descobrindo o mineyro, batendo a galaria [galeria], varrendo o fosso, e tambem a brexa, 
de tal sorte que hum destes a quem os Italianos chamão Canone tradictore [itálico nosso] ${ }^{117}$, porque atira para dentro da dita brecha.

A forma que se costuma dar ao orelhão pella mayor parte he redonda; ${ }^{118}$ o Conde de Pagan, e Antonio de Ville os fazem em forma quadrangular a que chamão espaldas; hu'a e outra couza se Est. 18 ve na figura 37, e diz o mesmo Ville liv. $1 .^{\circ}$ parte $1 .^{a}$ Cap. 24 que tem por melhor a espalda quadrilatera, que o orelhão redondo, porque he de menos despeza, e que no lanço RY se podem alojar mais soldados e artelheria mais commodam ${ }^{\text {te }}$ que na redondeza que se The acrescenta; ás quais razões apoya o Capitão Diogo Henriques de Vilhegas liv. $2^{\circ} \mathrm{Cap}^{\circ} 10$, a que acrescenta outras 3, a saber, por ser melhor defendido da cortina, por ter o inimigo mais que romper, e por se cobrir melhor o flanco; mas como não prova alguma destas razoens, e antes se demonstra o contrario, aprovamos antes os orelhões redondos.

Que se demonstre o contrario se prova facilmente (excepto no que toca á mayor despeza, a qual com tudo he tão pouca que se póde desprezar, alem de que fica bem recompensada essa mayoria com a mayor utilidade) porque quanto a razão de Antonio de Ville de que se podem alojar mais soldados, e artelheria mais Fig. ${ }^{a} 37$ Est.[18] commodamente no lanço RY do que na redondeza RXY que se the acrescenta, se ve manifestamente o engano e erro, poys conforme Euclides, o mais breve espaço do ponto $\mathrm{R}$ ao ponto $\mathrm{Y}$ he o da linha

\footnotetext{
${ }^{117}$ Canhão traidor. Da maneira como escreveu o nosso autor com um só "n" a palavra em italiano significaria cânone, mas o sentido na frase é de canhão que, mesmo no italiano antigo, se escrevia cannone.

${ }^{118}$ Nos parágrafos seguintes o nosso autor faz uma defesa cerrada do baluarte com orelhão redondo. Esta forma, entretanto, é praticamente inexistente no Brasil e Vellozo não conseguiu influenciar com este desenho nenhum exemplar em Pernambuco, que tenhamos conhecimento. $\mathrm{O}$ acabamento arredondado do ângulo da espalda no hornaveque do Forte dos Reis Magos no Rio Grande do Norte não se constitui em orelhão.
} 
recta RY, he logo mayor o da circular RXY: logo como póde ser que no mayor espaço cayba menor numero de gente do que no mais pequeno[?]; nem a redondeza impede a commodidade do alojamento assim da artelheria como dos soldados, porque no redondo se fazem muyto bem as canhoneyras, e se atira mais livremente para hu'a e outra parte; alem de que a dita redondeza he pouco sencivel, por ser a porção RXY hum pequeno arco de hum circulo grande.

Em quanto ás razões do Capitão Diogo Henriques de Vilhegas a primeyra em que diz que he melhor defendida da cortina a espalda plana do que o orelhão redondo he de pouco momento, porque he manifesto que de todos os pontos da cortina de que se podem tirar linhas rectas, e por ellas fazer tiro a todos os pontos da recta RY, se podem tambem tirar a todos os da linha circular RXY, sem haver algum que não fique do mesmo modo descuberto.

A segunda que o inimigo tem mais que romper sendo espalda plana, do que sendo orelhão redondo se responde que he erro, poys por ser mayor a linha circular RXY do que a recta RY, serão proporcionalmente mayores as partes daquella, que as desta; alem da mayor fortaleza na linha circular que não tem angulos, que são mais faceis de romper.

A terceyra de que se cobre melhor o flanco com espalda plana, que com orelhão redondo, tambem he falça [sic], porque sempre fica no mesmo sitio o ponto $\mathrm{Y}$ o qual he necessario salvar, ou arruinar para poder offender o flanco, o qual sem razão se diz que fica melhor cuberto com a espalda plana, que com o orelhão redondo; e desta mesma opinião he o Capitão Antonio Sarti no quezito 17, e tambem Erad [sic] de Barleduc liv. 2 Cap. ${ }^{\circ} 23$ pag. 20. 


\section{Assentado que he melhor o orelhão redondo que a} espalda quadrangular, resta dizermos a forma de os desenhar.

Partem huns todo o flanco ordinariamente em tres partes iguais sendo grande, ou em duas sendo pequeno, das quais tomão hu'a para o flanco cuberto e sobre as outras duas formão orelhão, ou espalda.

O Methodo Luzitanico parte $1^{\text {a }}$ secção $1^{\text {a }}$ Cap ${ }^{0} 28$ pag. 114 parte o flanco quando he grande tambem em tres partes, quando he mediano em cinco, e quando pequeno em duas; quando o reparte em tres toma hu'a para o flanco cuberto; quando em cinco toma duas, e quando em duas, toma hu'a.

Monsieur de Vauban, e o seu decipulo Ozanam os fazem iguais á terça parte do flanco.

O autor do novo methodo de fortificar a Franceza lhe dá sempre em todos os poligonos sete toezas seja o flanco grande ou pequeno.

O Conde de Pagan toma sempre a metade do flanco para o orelhão: Antonio de Ville, e Pedro Sardi the dão os dous terços.

Blondel, e Rogers lhe asignão 10 toezas; nesta variedade me parece melhor partir sempre o flanco pello meyo, seja grande ou pequeno, porque se for assim não ficará defectuozo o orelhão, nem o flanco cuberto, e se for grande ambos ficarão com bastante capacidade.

A sua construcção segundo traz o Methodo Luzitanico no Cap $^{0}$ apontado he a seguinte ${ }^{119}$.[:] Partase o flanco AB pello meyo (segundo a opinião que seguimos) no ponto $\mathrm{M}$, do qual se tire a linha $\mathrm{MN}$ ao angulo do baluarte opposto; na dita linha se tome

\footnotetext{
${ }^{119}$ A demonstração geométrica que se segue deve ser observada na Fig. 37 e não na Fig. 38, como indicado na nota da margem do texto.
} 
sempre MY igual a terça parte do mesmo flanco AB; outro tanto se tome na face EA produzida athe R; dos pontos Y, e R, com o mesmo intervallo YM, ou AR se descrevão dous arcos que se cruzem no ponto $\mathrm{Z}$, do qual como de centro no papel com o compasso, e na campanha com hum cordel se descreva a redondeza RXY, e ficará formado orelhão; mas se houver de ser espalda não ha mais que lançar a linha RY, e ficará feyta.

Da mesma sorte se obrará no cazo que se não tome a metade do flanco para nelle se descrever o orelhão, mas os dous terços como querem huns, ou os tres quintos como querem outros.

Muytos quando os baluartes são demaziadamente grandes em lugar de sahirem com os orelhões ou espaldas para fora, entrão com elles para dentro do corpo do baluarte, no que aumentão alguns palmos o flanco; esta opinião seguem o Conde de Pagan, Fig ${ }^{a} 38$ Est. 18 e Monsieur de Vauban, e se faz partindo o flanco OQ tambem pello meyo no ponto $\mathrm{P}$, e a sua ametade $\mathrm{PQ}$ proxima a cortina se retira para dentro 20 ou 25 pés [6,6 ou $8,25 \mathrm{~m}$ ] como se ve na mesma figura 38 no baluarte $\mathrm{ONK}$, e se tira a linha VF perpendicular sobre a demigola, e igual a ametade do flanco PQ, e ultimamente tirando a linha PF ficará feyta a espalda OPF; mas querendo fazer o orelhão dos pontos $\mathrm{O}$, e $\mathrm{P}$ com a distancia $\mathrm{PF}$, ou $\mathrm{QV}$, que he a mesma, se descreverão dous arcos que se cruzem no ponto $\mathrm{D}$, do qual como de centro se descreverá a redondeza PLO, e ficará formado o orelhão, mas isto so se faz nos baluartes demaziadamente grandes, em que as faces são tambem muyto grandes, pellas não fazer mayores, que fiquem fora da sua divida proporção, e tambem porque a grandeza das demigolas permite cortarselhe aquella parte, sem ficarem defectuozas. 


\section{$\operatorname{Cap}^{\circ}{ }^{8} .^{\circ}$ \\ DOS FLANCOS ALTOS E BAYXOS.}

Antigamente se fazião hu'as cazas nos flancos com suas canhoneyras para disparar a artelheria por cuja razão se chamavão cazas armadas, e em latim casa armata ${ }^{120}$, e dahi corrupto vocabulo caza mata; seu plano era o livel da estrada encuberta, mais bayxo, ou mais alto conforme a opinião do Engenheyro que as fabricava; por sima erão cubertas de abobedas sobre as quais se formavão outras baterias altas: a sua largura era na terça parte ou ametade do flanco: a retirada ou fundo era tambem vario segundo a cada hum parecia necessario para o manejo da artelheria, e conforme permitia a capacidade da demigola para nella se fundar a dita caza mata, e juntamente ficar lugar bastante para a serventia do baluarte.

Porem mostrou a experiencia os grandes incomodos destas cazas matas, porque disparando a artelheria se enchião com a fumaça de tal modo que ali se não podia aturar, nem ver para tornar a carregar, não obstante de se lhe abrirem por sima alguns respiradouros para sahir o fumo: ${ }^{121}$ tambem o estrondo da artelheria as

\footnotetext{
${ }^{120} \mathrm{O}$ termo deve ter derivado diretamente dos tratadistas militares italianos, mas o autor não erra quando diz que a origem é do latim, porque o termo casa-ce era utilizado nesta língua, em lugar de domus, quando queria significar casinhola ou pequena casa (Virgílio). Vegécio chamava de casa a tenda do soldado.

${ }^{121}$ Este procedimento de projeto criando casamatas foi cada vez mais combatido, a partir da segunda metade do Século XVII, não somente pelo inconveniente da fumaça, mas, principalmente pelos gases derivados do carbono que se originam da combustão da pólvora $\left(\mathrm{COeCO}_{2}\right)$ que são mortais, quando inalados em determinada quantidade. Em 1729, Azevedo Fortes já declarava o seu desuso ao afirmar: e neste lugar [praças-baixas] se fazião as casas-matas, que já hoje se não usão pelas razões que veremos no discurço deste Tratado. Muitos historiadores não afeitos a terminologia militar das fortificações chamão de casamatas os cômodos abobadados das fortalezas incorporados ao terrapleno sob a plataforma dos canhões e alguns desenhistas das fortificações, no passado, nominavam desta maneira tais espaços criando confusão, como no caso da Fortaleza de S.José, em Macapá. A casamata por definiçãoé armada e abriga uma ou mais peças de artilharia. Vejamos como casamataédefinida por Serrão Pimentel: Casamatahehúa Praça cubertadeabobada a moda de húa casa quesefaz nosflancos dosbaluartes, onde se aloja artitheria para se atirar no inimigo [...]. A definição dada por Azevedo Fortes está na mesma linha quando afirma: [...] tinhãosuascanhoneirasporondejugava a Artelhariadebaixo daabobeda.
} 
abalava de sorte, que muytas vezes bastou este aballo para sua roina, e muyto mais sendo ajudado da bateria do inimigo.

Por tanto se resolverão os modernos a fazer em lugar das cazas matas hu'as praças descubertas e detraz dellas outras mais altas, porque sendo descuberta por sima a praça bayxa ficava livre dos inconvenientes referidos, e desta sorte he que se dividem os flancos em altos e bayxos segundo dizemos no principio deste Cap ${ }^{\circ}$.

Costumaose construir estes flancos bayxos no espaço do flanco cuberto; o seu plano deve ficar no meyo da altura do fundo do fosso athe o cordão, ou raiz do parapeyto, o qual para servir na praça bayxa deve ter 18 pés $[5,94 \mathrm{~m}]$ de largo, e de alto no interior seis $[1,98 \mathrm{~m}]$, e quatro $[1,32 \mathrm{~m}]$ no exterior, com suas canhoneyras para as pessas que commodamente puderem caber, dando a cada hu'a 12 pés [3,96m], e para ainda poderem jogar mais folgadamente se alargará o plano da dita praça bayxa para a parte do angulo da espalda 8 ou 10 pés [2,64 ou 3,3m], e tambem da parte da cortina, correndo o lado da praça bayxa por hu'a linha parallela a razante: o fundo ou retirada deste parapeyto deve ter ao menos 24 pés $[7,92 \mathrm{~m}]$, ao mais $30[9,9 \mathrm{~m}]$.

Monsieur de Vauban faz os seus flancos retirados em arco, e sem duvida que quando este não for demaziado que he muyto melhor que o que he em linha recta, porque alem de poder accommodar mais soldados, e mais artelheria (como ja provamos do orelhão redondo) reziste mais aos tiros da artelheria inimiga; os merlões das canhoneyras ficão mais fortes, como trazem Pfefinger liv. $4^{\circ} \mathrm{Cap}^{\circ}$ $6^{\circ}$ pag. 202; o nosso Engenheyro Portuguez liv. $2^{\circ}$ pag. 114.

O fim porque se fazem estes flancos ou praças bayxas he o mesmo porque ja antigamente se fazião as cazas matas, a saber, porque sendo aquella praça melhor defendida que tem mayores 
flancos quizerão com esta invenção multiplicalos para assim accommodar mayor numero de artelheria, que he a principal defença quando ja o inimigo tem entrado no fosso, e intenta passalo cuberto com a galeria, ou traveça, e de nenhum modo se póde conseguir melhor o intento de alojar muyta artelheria, e toda capaz, e dezembaraçada para jogar ao mesmo tempo do que fazendo muytos flancos huns mais altos que os outros.

Esta he a razão porque Vauban não so faz primeyro e segundo flanco, mas tambem terceyro, dando a cada hum 12 pés [3,96m] de alto, principiando o primeyro do fundo do fosso.

A serventia para a dita praça bayxa deve ser por hum corredor de abobeda de 7 ou 8 pés [2,31 ou 2,64m] de alto, e outro tanto de largo, que atravecará o corpo do reparo, como tudo se ve na Est. 19 figura 39 na qual a letra A mostra a estrada de rondas no alto da muralha; B o parapeyto detraz della; C o plano da praça bayxa, que fica em meya altura do fundo do fosso athe o cordão; D a entrada da abobeda para acodir á praça bayxa; E parapeyto do flanco alto; F mostra hu'a serventia em ladeyra, ou em degraos descuberta entre duas paredes que deve haver do alto do baluarte athe a praça bayxa, e dahi athe o fosso dezembocando nelle por hu'a porta onde esta a letra Z: as mais circunstancias se explicão miudamente no Methodo Luzitanico $P^{\text {te }} 1^{\text {a }}$ Cap $^{0} 29$ onde se podem ver ${ }^{122}$.

Isto he havendo hu'a so praça bayxa, que he so o que nas nossas praças se costuma fazer porem nas grandes praças, e baluartes bem abertos se póderão fazer duas praças bayxas, e neste cazo se repartira a altura do fundo do fosso athe o cordão em tres partes iguais, e na altura da primeyra parte inferior se fará o plano

\footnotetext{
${ }^{122}$ A letra "D" e "F" não se encontram representadas no desenho original.
} 
da primeyra praça bayxa, na altura da segunda parte o plano da segunda praça bayxa, e na terceyra parte o plano da praça alta, a qual sempre deve ficar no livel da altura do terrrapleno do baluarte: as ditas praças bayxas terão ambas a largura e fundo ja dito, e a mesma grossura de parapeytos, e serão revestidas de muralhas de pedra e cal: mas então he necessario que os 20 ou 25 pés [ 6,6 ou $8,25 \mathrm{~m}$ ] de retirada para o orelhão se tomem para fóra na face produzida por não comer tanto as demigolas.

Não falta com tudo quem as queyra reprovar oppondo as seguintes objeções.[:]

A primeyra que os flancos ou praças bayxas expoem a praça a risco de ser perdida por hu'a entrepreza, porque por respeyto de sua pouca altura poderá o inimigo por ellas escalar a praça e rendella.

Mas a isto se responde que no tempo da paz se deve sobre o parapeyto do flanco bayxo fazer hu'a parede de pedra e barro, ou de pedra seca de dous $[0,44 \mathrm{~m}]$, ou dous palmos e meyos $[0,55 \mathrm{~m}]$ de groço e 12 ou 14 [2,64 ou 3,08m] de alto para estrovar [estorvar] as entreprezas que se poderião fazer em razão da pouca altura do tal flanco, a qual parede se derruba facilmente quando a necessidade o pede, e isto alem das mais cautellas que se apontão no Methodo Luzitanico Capos 30 e 31 para segurar as praças bayxas nem he facil que por ellas se ganhe hu'a praça, porq' para os acontecimentos repentinos bastão as defenças exteriores, a saber a estrada encuberta, o fosso, e as obras que dentro nelle se podem fazer, como adiante se dirá; e quando sucedese que a fortaleza fosse entrada pella praça bayxa, seria antes effeyto de grande descuydo que defeyto da praça bayxa poys se suppoem que deve haver cuydado, e a vegilancia necessaria, sem a qual fica sugeyta ao mesmo perigo toda a fortaleza por qualquer de suas partes. 
A segunda objecção he, que tanto que o inimigo tiver feyto sua espalda, ou travez no fosso fica logo cuberto do danno que se lhe póde fazer da praça bayxa em razão da sua pouca altura, e por tanto he escuzada.

Mas a isto se responde que na praça bayxa se devem pôr tres canhões groços, os quais como offendem com tiros mais horizontays, obrarão com mais eficacia que de outra qualquer parte da fortaleza, e assim custará ao inimigo $\mathrm{m}^{\text {to }}$ mais tempo muyto mais trabalho, e dobrado risco o cobrirse, principalmente porque nunca poderá fazer a sua galaria [galeria] tão solida que rezista aos tiros dos ditos canhões da praça bayxa, porque segundo refere Goldman liv. 1. ${ }^{\circ} \S$ da Ortrogafia [sic], hum canhão de $48^{123}$ atirando a distancia de 400 pés [132m] passa hum parapeyto de 20 [6,6m] de groço; hum meyo canhão de $24^{124}$ a distancia de 300 pés [99m] entra na terra 12 [3,96m]; o quarto canhão de $12^{125}$ a distancia de 200 pés $[66 \mathrm{~m}]$ penetra quazi 7 [2,31m], suppondo que atirão contra hum parapeyto ou reparo de boa terra, e bem unida, o que não podem ter as galarias que são obradas com muyto temor, e preça.

A terceyra objecção que oppoem he que os defensores que assistem na praça bayxa estão arriscados a serem offendidos das ruinas da praça alta cauzadas pella bateria inimiga, e que por tanto senão deve fazer praça bayxa.

\footnotetext{
${ }^{123}$ Esta indicação da capacidade do canhão era, normalmente, feita pelo peso das balas qua lançava o artefato, explicitado em arráteis e suas frações em onças. Com este valor de $48[\sim 22 \mathrm{~kg}]$ seria uma categoria de canhão, aproximadamente, do tipo comum ou batemuros. Para se ter uma idéia mais completa do assunto consultar o Cap. I do nosso livro: As fortificações portuguesas de Salvador quando "Cabeça do Brasil".

${ }^{124}$ Seria um canhão de 24 arráteis [ $11 \mathrm{~kg}$ ] de bala, que entra na categoria de meio canhão, cognominado de brecante.

${ }^{125} 12$ arráteis $[5,5 \mathrm{~kg}]$ de bala.
} 
A isto se responde que este risco era no tempo que a praça alta se fundava em abobedas sobre a bayxa quando esta por ser cuberta tinha o nome de caza mata, porque arruinando o inimigo as paredes sobre que as abobedas se fundavão vinhão estas abayxo com risco e danno dos que assistião na caza mata, mas depoys que se fes descuberta tomando o nome de praça bayxa evitou este inconveniente, porque como a praça alta fica retirada couza de 24 athe 30 pés $[7,92$ até $9,9 \mathrm{~m}$ ], ainda que a roina occupe 8 ou 10 pés [2,64 ou 3,3m] sempre ficão livres 16 , ou 20 [5,28 ou $6,60 \mathrm{~m}]$ em que se póde accommodar a gente; alem de que assim como se vay fazendo a roina podem os defensores hir tirando a terra, ou materiays da muralha para dentro da fortaleza, e dezembaraçando o sitio da praça bayxa.

Tambem para evitar este risco das bombas que cahirem na praça bayxa fazem os modernos hum fosso de 18 palmos [3,96m] de largo, e outro tanto de fundo, e desta sorte fica seçando o inconveniente sobredito.

A quarta objecção he que fabricandose praças bayxas se diminue a gola, e a area do baluarte pelo terreno que o occupão as duas praças bayxas, e duas altas em cada hum delles.

Mas respondese a isto negandose o antecedente, porque na deligniação da obra se attende logo a que fique bastante capacidade para a gola, e area do baluarte, alem do terreno que occupão as praças bayxas e altas, com seus parapeytos, dandose por esse respeyto o comprimento necessario as demigolas e flancos, e por tanto não se póde dizer que se minorão as gollas, e a area do baluarte quando ficão da largueza necessaria para a commodidade dos defensores.

A quinta objecção he, que a praça bayxa conserva sua defença somente em quanto se não arroina a porção do flanco que ha 
entre ella, e o angulo da espalda do baluarte, e que arroinda [arroinada?] a dita porção do flanco fica a praça bayxa toda exposta, e por tanto inutil, e assim que he escuzada.

Respondese a isto, que aquella porção do flanco não póde ser mais facilmente arroinada que qualquer outra parte da fortaleza a que o inimigo puzer bateria, e nem por isso se deyxão de fazer todas aquellas partes que podem aumentar a defença e embaraçar ao inimigo; e como da praça bayxa se ajuda muyto a defença, e se embaraça o inimigo na passagem do fosso, não se devem desprezar pela razão de que arruinada a parte do flanco que as cobre, ficarão descubertas e inuteys; quanto mais que os defensores devem estar continuamente reparando todas as ruinas que o inimigo vay fazendo com suas baterias.

A sexta objecção he que as praças bayxas não servem mais que para defença da brecha que o inimigo abre na face do baluarte, ou na cortina; mas esta so conveniencia não he de tão grande consequencia que por ella se despreze o muyto custo que fazem as ditas praças bayxas, logo não se devem fazer.

Respondese que não defendem somente a brecha feyta na face do baluarte, ou na cortina, mas que tambem fazem oppozição a bataria que o inimigo costuma fazer na contraescarpa, e a brecha que abre na mesma contraescarpa $\mathrm{p}^{\mathrm{a}}$ decer ao fosso, que arruinão e desfazem a galaria, ou travez com que o inimigo pertende atraveçar o mesmo fosso; e ainda que somente servicem para defender as sobreditas brechas da face e cortina, não era esta tão pequena conveniencia que se desprezasse a troco de poupar o mayor custo; porque so para impedir este ultimo fim, e accometimento do inimigo he que se fes toda a fortificação. 
Acrescentão mais alguns que os Holandezes não costumão fazer praças bayxas, e dahi arguem, que ou não devem ser boas, ou se podem escuzar.

A isto se responde que a cauza de as não fabricarem he que de ordinario fazem as suas fortificações de terra, em que se não podem bem sustentar os orilhões [sic], segundo o que ja se disse no Cap. ${ }^{\circ} 7^{\circ}$; e por tanto suprem a falta das praças bayxas com obras exteriores, mas nem por isso ficão melhor defendidas as suas fortificações, poys ha mostrado a experiencia que dezembocado o fosso está quazi perdida a praça, o que não he assim quando ha praças bayxas.

Contra o uso das altas quando ha aquellas se propoem tambem outras objecções, como largamente refere o Cap. ão Diogo Henriques de Vilhegas na sua Academia liv. $2^{\circ}$ Cap. ${ }^{\circ} 11 \S 3^{\circ}$ e são as seguintes.[:]

Primeyramente dizem que as praças altas expoem a evidente perigo os defensores que assistem nas bayxas, em razão de que na occazião da pelleja se podem ascender os barriys [sic] de polvora que ali estão destapados para o uzo da artelheria pellos estopins e buchas das pessoas que se disparão da praça alta, e cahem acezos na bayxa.

A isto se responde que nas praças altas se devem, e costumão carregar as pessas com as cargas em cartuchos de papel groço, ou de pano, e havendo de atirar ao plano do fosso se deve atacar a balla com hum taco de madeyra para que apontando a pessa para bayxo não corra a balla, e que os artilheyros praticos da praça bayxa não devem ter os barriys de polvora destapados como suppoem o argumento, mas cubertos, e em lugar seguro para que estejão livres deste risco; e por esta razão he que no Methodo 
Luzitanico pag. 122 acerca da fabrica das praças bayxas se acrescentou na serventia de hu'a para outra hu'as recameras ou payos cubertos de abobeda para nelles ter a polvora resguardada.

A segunda objecção he que a praça alta não descobre mais que a terça parte do fosso, por ficar retirada atras da praça bayxa, e assim não he de grande consequencia, e por tanto se póde escuzar.

A esta se responde, que ainda que as praças altas não descubrão mais que a terça parte do fosso são de grandissima utilidade, e consequencia, poys descobrem aquella parte que corre junto á face do baluarte opposto, que he por donde o inimigo pertende [pretende] senhoriarse delle, atravesando por ali o fosso com a galaria, ou travéz, para dar o assalto pella brecha que tiver disposta com sua bateria na face, como mais exposta ao ataque, e mais facil de por ali invadir a praça, e assim que se consegue hu'a grande utilidade em si aumentar a defença com se descobrir da praça alta aquella parte do fosso.

Respondese mais, que he falso dizerse que da praça alta se descobre somente a terça parte do fosso, porque se descobre tambem a contraescarpa, e aquella parte da estrada encuberta que corre desde o angulo da contraescarpa para o do baluarte, na qual parte o inimigo costuma plantar sua bateria, como em sitio mais commodo $\mathrm{p}^{\mathrm{a}}$ dali desmantellar as defenças dos flancos, e contra este sitio se faz grande oppozição da dita praça alta, o que não he de pequena consequencia: descobre-se tambem o portilho que o inimigo abre na contraescarpa defronte da face do baluarte, pello qual portilho dezemboca no fosso, e pertende atravessallo por meyo da galaria ou travez, a qual the será necessario fabricar mais levantada a respeyto de se poder cobrir da artelheria da praça alta, o que tudo são effeytos de grande importancia que se conseguem por meyo da dita praça alta, duplicando as defenças da bayxa, e dando mais trabalho e risco ao inimigo. 
A terceyra objecção he que os tiros da praça alta para o plano do fosso ficão muyto oblicos, e por tanto de pouco effeyto, donde parece que se a praça alta he para defender o fosso fica frustrado o intento.

A isto se responde que a praça alta não he só para defender o fosso, mas tambem para defender a contraescarpa, e a estrada encuberta; e dado cazo que so fora para defender o fosso, ainda que os tiros sejão oblicos nem por isso deyxão de fazer grande effeyto, e obrigarão ao inimigo a serlhe necessario para se cobrir a levantar os seus reparos a mayor altura, com mayor trabalho e dilação, como se tem dito na reposta [resposta] da segunda objecção.

A quarta he que os defensores que assistem na praça alta ao manejo da artelheria são tão molestados pello fumo que sobe da bayxa, e os cega de tal modo que não podem descobrir o sitio a onde devem atirar, e por tanto fica frustado o fim para que se fabrica a dita praça alta.

A esta objecção se responde negando-a, porque a experiencia mostra que por ser a praça bayxa descuberta se desfaz logo o fumo, principalmente correndo qualquer ar de vento; e como naturalmente o fumo sobe, e da praça alta se atira a posto inferior, sempre fica descuberta a pontaria; e cazo negado que o fumo a impedira, podiase ter feyto certo signal em que se assestar a pessa no sitio conveniente, para que ainda que adiante houvesse fumo sempre o tiro va derigido á parte da pontaria que primeyro se fes, e tambem se faz outro signal nas cunhas ${ }^{126}$ da pessa para que esta sempre

\footnotetext{
${ }^{126}$ As antigas peças de artilharia não possuíam mecanismo para fazer a elevação do cano. Na parte posterior do tubo (zona da culatra) era colocada uma cunha de madeira que descansava sobre a travação da carreta ou do reparo. A cunha ao ser empurrada abaixava o cano do canhão e ao ser, progressivamente, retirada fazia movimento contrário.
} 
atire pello mesmo ponto; e isto he tambem o q' se pratica quando se atira de noute, tendose feyto de dia as marcas em que deve atirar a pessa: quanto mais que os soldados, e artilheyros praticos não devem fazer por este e por outros respeytos os tiros da praça alta e bayxa em hum mesmo tempo, mas disparadas as pessas da alta, se devem então disparar as da bayxa para no entretanto se irem revezadam ${ }^{\text {te }}$ carregando humas, e disparando outras, para assim ter ao inimigo em hum continuo tormento quando a occazião o pede; com o que disparadas as pessas da praça bayxa em quanto se tornão a carregar, fica muyto lugar de se desfazer o fumo para que as pessas da alta se descubra livremente a pontaria.

A quinta objecção he a respeyto do custo que fazem as praças altas, as quais parece se podião escuzar quando ha praças bayxas, cavaleyros, e outros lugares donde se defender a fortaleza.

A esta se responde, que quando se attende a melhor defença, e mayor segurança da praça, se não deve reparar no custo; e se não ha cabedal para isso, não se segue dahi que a obra seja escuzada, antes se segue que ficará a fortaleza imperfeyta, e em perigo de se perder, que he muyto mayor damno [sic] que o do gasto da fabrica, e o mayor damno [sic] sempre se deve evitar, ainda que seja a troco do menor, quando não póde ser de outro modo.

\section{Assentada por tanto a grande utilidade que se segue} de haver praças bayxas, resta dizermos a forma do seu desenho, a qual he a seguinte.[:]

Fig. ${ }^{a}$ 40Est.[20] Do revez do orelhão AF se tomem nove palmos [1,98m] de $\mathrm{A}$ athe $\mathrm{E}$; e na producção da cortina $\mathrm{CD}$ se tomem de $\mathrm{C}$ athe $\mathrm{B}$ outros nove palmos, e então se tire a linha EB, a qual será a fundamental da dita praça bayxa, da qual para dentro se dará a grossura da muralha ordinaria de quatro pés [1,32m], e della para fóra se 
The dará a largura da baze da escarpa, a qual (como temos dito no Cap $^{\circ} 5^{\circ}$ in fine) deve ser a quinta parte da sua altura.

A altura destas praças bayxas ja dizemos no principio deste Cap. ${ }^{\circ}$ que deve ser a metade da altura da muralha, tomada do fundo do fosso athe o cordão; sem embargo de que o Engenheyro Portuguez $\mathrm{Cap}^{\circ} 7^{\circ}$ pagina 118 faz a dita altura na grande e mediana fortificação, nove palmos $[1,98 \mathrm{~m}]$ mais alta que o livel da campanha, mas na pequena lhe dá so seis palmos [1,32m]; quem quem quizer escolha aquella de que mais se agradar, com tanto que nunca seja mais bayxa q' o livel da estrada encuberta.

Supposto dizemos no principio deste Cap. ${ }^{\circ}$ que o fundo que deve ter a dita praça bayxa, alem do parapeyto deve ser de 24 , ou 30 pés $[7,92$ ou $9,9 \mathrm{~m}]$ ao mais, que he o que basta para o recuo da artelheria; deve tambem ter de mais o que se lhe dá para largura superior do fosso, que se faz entre ella e o flanco alto, que costuma ser de 12 athe 18 pés [3,96 até $5,94 \mathrm{~m}$ ], e assim vem a ser todo o fundo da praça bayxa de 60 athe 66 pés [19,80 até 21,78], que he o mesmo com pouca differença que the da Monsieur de Vauban.

Costuma este selebre [sic] autor, e tambem o do novo methodo de fortificar á Franceza fazer tanto estas praças bayxas (a que dá o nome de flancos bayxos) como os altos em arco, porque dizem que desta sorte rezistem melhor aos tiros da artelheria inimiga accommodão mais defensores, e ficão os merlões das canhoneyras mais robustos o que confirma o nosso Engenheyro Portuguez, não sendo a volta com excesso, o que tambem he defeyto, e para evitar este tomão entre as pontas do compasso a distancia entre os pontos E e B, e com ella descrevem para a parte Fig. ${ }^{a}$ 41 Est. [20] do fosso dous arcos que se cruzem no ponto $\mathrm{X}$, do qual como de centro descrevem com a distancia $\mathrm{XE}$, ou $\mathrm{XB}$, o arco $\mathrm{BE}$, que vem 
a ser a sexta parte de hum circulo; da mesma sorte obrão para formar o flanco alto curvo, porque tomão no revez do orelhão do

Fig. ${ }^{a} 41$ Est.[20] ponto B para dentro nove braças [19,8m], e outras nove na produção da cortina do ponto E para dentro, e dos pontos $\mathrm{F}$ e $\mathrm{H}$ onde se terminão as ditas nove braças como de centros descrevem para a parte do fosso dous arcos que se cruzem no ponto $\mathrm{Z}$, do qual como de centro com a distancia $\mathrm{FH}$, descrevem o flanco curvo FGH, e com esta mesma distancia se descrevem os primeyros dous arcos que asima dizemos.

$$
\operatorname{Cap}^{\circ} 9
$$

DO BALUARTE, SE POR SER GRANDE REQUERE MAYOR NUMERO DE GENTE

PARA GUARDALLO, E DEFENDELLO DO QUE REQUERE SENDO PEQUENO.

Não ha couza tão clara que não padeça suas objecções, e assim houve alguns auctores que se oppuzerão a os baluartes reays especialmente por duas razões que refere o Capitam Antonio Sarti no quezito 18, hu'a he que dizem que estes baluartes (alem da mayor despeza que se faz em sua fabrica) necessitão de muyta gente assim em tempo de paz, como muyto mais em tempo de guerra para os guardar e defender, a respeyto da que necessitão os baluartes que não são reays, a saber os baluartes mais pequenos, e que do mayor numero de gente se segue ordinariamente a falta de mantimentos na praça, o que tem sido muytas vezes cauza de esta se perder.

A segunda razão he, que sendo o baluarte grande se dá mais campo ao inimigo para fazer suas baterias, por cuja cauza dizem que elle terá depoys mayor facilidade, e commodo para poder dar o 
asalto com mayor numero de soldados, pela grande brecha que houver feyto para introduzirse dentro.

Porem estas razões são de nenhum vigor; primeyramente acerca da mayor despeza se deve conciderar se he necessaria, e della se segue melhoria para a defença, e sendo assim não se deve escuzar, porque do contrario se podia seguir a perda da praça, que he o que se deve antever e evitar, a troco de todo o custo.

Quanto ao mayor numero de gente se responde que no tempo da paz tanto necessitará o baluarte pequeno como o grande, porque sendo estes córpos de figura e forma semelhante requerem as mesmas sentinellas no angulo flanqueado, e nos da espalda, sem que requeyra mais o baluarte grande que o pequeno, nem tão pouco mayor numero de rondas; e no tempo da guerra nunca estes corpos podem receber tão grande numero de gente, que lhe não seja necessaria mais para rebater hum assalto, e opporse a toda a força e violencia do inimigo, e por tanto nunca a grandeza dos corpos rezulta em danno, mas em beneficio da defença: de mais que nem sempre por ser o recinto grande necessita de ser todo em roda igualmente guarnecido, poys não póde ser por toda a parte igualmente combatido, e assim por onde o for com mais força he necessario largueza para que cayba a gente que das outras partes vem a socorrer; e pello contrario se os baluartes forem pequenos não terá o governador lugar de se aproveytar da sua gente para onde the for necessario fazer mais esforço, e assim perderá pella estreyteza do baluarte a defença q' póde fazer no grande, e por esta cauza perderá a praça.

Quanto ao que se diz na segunda obejeção [sic] que com a grandeza do baluarte se da lugar e commodo ao inimigo a fazer mayor brecha com sua bateria; se responde que por mais numerozo 
que seja o exercito do inimigo nunca uza de derrubar mais com suas baterias que hum espaço de 120 pés $[39,6 \mathrm{~m}]$ de comprido mais $10[3,3 \mathrm{~m}]$ menos 10 [3,3m], seja a face do baluarte de 300 pés [99,0m], seja de 400 [132,0m], ou seja ainda mayor, no qual espaço de 120 pés [39,6m] medido a olho ferquenta [sic] depoys e profunda a bateria, ou tambem se valle de fornilhos e mina, e de amontoar fachina no fosso ao pé da brecha para facilitar a sobida; e cometeria erro em perder tempo a bater toda hu'a face, se pouco mais, ou ainda menos de a metade lhe basta: por tanto podese afirmar que as oppozições feytas contra os baluartes reays são de nenhum vigor, e que fazendo-os antes grandes que pequenos que se seguem as golas espaçozas, as quais servem para nellas se fazerem com largueza as praças bayxas, e ficar passagem livre e larga para os soldados, e serventia do baluarte: alem disto sendo necessario cavar hu'a contramina se poderá fazer com perfeyção, não receando aquelles impedimentos que sucederião no baluarte pequeno: sendo necessario fazer hu'a ou mais cortaduras se poderão fazer grandes, e reays, bem differentes daquelles que se fazem nos baluartes pequenos, pelo que estes se devem alargar quanto possa ser sem inconveniente, nem disformidade.

\author{
$\operatorname{Cap}^{\circ} 10$ \\ SE OS BALUARTES DEVEM SER \\ CHEYOS OU VAZIOS.
}

Esta duvida he so nos baluartes grandes, a saber se nestes o reparo deve ser so da mesma largura que nas cortinas ainda que no meyo fiquem vazios, ou se devem inteyramente terraplenar; 
Fritach liv. $1^{\circ} \mathrm{Cap}^{\circ} 9$ diz que o mais ordinario he fazerem-se vazios, porque assim fazem menos despeza, e são mais proprios para descobrir as minas dos inimigos.

Porem Antonio de Ville liv. $1^{\circ}$ Cap. ${ }^{\circ} 30$ diz que nenhu'a pessoa bem entendida na fortificação contradirá que são melhores os baluartes cheyos que vazios, e que nas melhores praças os vio sempre fazer cheyos; o fim he para haver grande praça onde formar hum grande numero de soldados para sustentar o combate, $\mathrm{e}$ a defença, e para haver lugar de fazer fossos, e intrincheyramentos para retiradas, as quais devem ser sempre mais altas que as de fóra.

Diz mais que pello contrario nos baluartes vazios ou a brecha seja feyta pella artelheria, ou por mina de ordinario não ficará de traz della bastante lugar sobre a largura do reparo para fazer intrincheyramentos, pello que será forçozo fazellos no bayxo, e neste lugar não se poderão fazer mais altos que os reparos, e mais obras exteriores, segundo requere a maxima geral da fortificação, que as defenças mais proximas do centro da praça devem ser mais altas que as de fora; e se então se devem entulhar, mal, e com preça será melhor fazello de antemão, e com vagar; e por tanto os baluartes cheyos são melhores que os vazios.

Nem obstão as rezoens [sic] contrarias, porque quanto a mayor despeza se tem ja dito sobre outros particulares, que esta se não deve escuzar quando he necessaria; e quanto a descobrir as minas do inimigo, tambem nos baluartes cheyos se fazem contraminas pellas quais se possão aquellas descobrir, e impedir.

Não querem estar por estas razões o Conde de Pagan, Monsieur de Vauban, o nosso Engenheyro Portuguez, e o autor do methodo dos tres guias, porque todos em oppozição de Antonio de Ville, aprovão os baluartes vazios, e intentão provar que 
nos baluartes cheyos se não faz tão bem a cortadura como nos vazios, tirando nestes hu'a cortina de hum flanco ao outro, que ficara logo guarnecida de seu fosso, o qual no baluarte cheyo será necessario fazer com grande trabalho, e despeza.

Dizem tambem que no baluarte de praça vazia se podem fazer dentro nelles armazens, tanto para as monições de guerra, como de boca ${ }^{127}$, que he hu'a grande conveniencia, mas sem embargo desta, e das mais apontadas pellos ditos AA [autores], eu tenho

por melhores os baluartes cheyos seguindo a Pfeffinger, e a outros com o dito Antonio de Ville, e ainda alem das razões que este auctor aponta ha tambem outra de muyta concideração em favor dos cheyos, que he poderem-se nelles fazer cavaleyros, assim para descobrir melhor as partes da campanha, como para se opporem a algum padrasto; e finalmente tem quantidade de terra para reformar os lugares arruinados, tapar as brechas que o inimigo fizer, e que não falta nelles materia para se fazerem cortaduras formadas por hum parapeyto, como em seu lugar diremos.

\author{
$\mathrm{Cap}^{0} 11^{\circ}$ \\ SE SÃO MELHORES OS BALUARTES \\ ATACADOS ÁS CORTINAS, OU SEPARADOS DO \\ CORPO DA PRAÇA.
}

O Cap ${ }^{\mathrm{am}}$ Francisco Tensine Cap ${ }^{\circ} 17$ pag. 37 dispoem os baluartes de sua fortificação separados do corpo da praça, porque diz que perdendose o baluarte, com dificuldade póde o inimigo entrar

\footnotetext{
${ }^{127}$ Dentre os muitos exemplos podemos citar baluartes vazios na famosa Praça de Almeida, em Portugal.
} 
dentro do recinto da fortaleza, pello impedimento da desunião, havendo huma estrada no meyo larga 10 pés [3,3m], e parallela ás cortinas, a qual estrada he defendida dos outros baluartes que estão dos lados.

Acrescentão os que seguem esta invenção que pella dita estrada se terá o commodo das sortidas, e que no tempo da paz podem estar estes baluartes sem sentinellas, ou guardas, principalmente nas cidades habitadas, por se não poder sobir a elles estando tapadas as portas.

Porem tudo isto he sem fundamento, porque quanto ao que primeyramente se diz de não poder o inimigo entrar dentro na fortaleza a respeyto da estrada que sepára o baluarte se responde, que sempre quem for senhor do baluarte, o será tambem da dita estrada, a qual facilmente se entulhará com a materia que cahe dos angulos dos flancos batidos, e quando esta não baste, com a mesma terra do baluarte a tapara de modo que as portas das sortidas fiquem inuteys, e tambem o fique a defença dos flancos dos outros baluartes, e com isto poderá o inimigo dentro da mesma estrada, sem impedimento, nem estorvo algum minar, e voar o reparo interior na gola do baluarte, e por ali senhorear-se da praça.

Quanto poys a dizerem que em tempo de paz podem estes baluartes separados estar sem sentinellas se responde, que quando assim fosse podia ser muyto perjudicial [sic], poys se tantas entreprezas de que estão cheyas as istorias tem tido effeyto contra lugares guardados, porque não sucederá o mesmo contra os baluartes separados, e dezemparados, nos quais tendo o inimigo entrado, terá a mesma ventagem sem embargo de estarem separados, que tem em outra qualquer praça depoys de haver ganhado hum so baluarte. 
Nem se póde replicar que tambem em muytas partes se não costumão em tempo de paz guardar as obras exteriores que ficão fóra do fosso, as quais depoys descreveremos, porque ha muyta diferença em ser o corpo principal da fortificação depoys do qual não resta mais que hum simples muro, o qual ainda he força ser aberto em todos os angulos, ou serem obras exteriores, que ainda que não sejão guardadas, he com tudo sempre guardado o corpo da praça, da qual se poderá rebater os que forem entrados por entrepreza nas ditas obras exteriores, e impedir aos que os quizerem socorrer: pello que a invenção dos baluartes separados não he para ser seguida, porque alem das sobreditas razões, diminuem os flancos, a saber, diminuem sertamente aquelles dez pés [3,3m] que occupa a estrada que fica entre elles e o corpo da praça, e são mais custozos, porque he necessario fazeremse dous muros para sustentar as terras nas suas golas, e formar a estrada para a separação, os quais dous muros se escuzão sendo os baluartes atacados ao corpo da praça; assim que tendo estes igual defença, e sendo menos custozos se devem preferir.

\author{
$\operatorname{Cap.~}^{\circ} 12 .^{\circ}$ \\ DAS OBRAS QUE SE COSTUMÃO FAZER \\ DENTRO NOS FOSSOS
}

Huma das principays obras (e muyto util) que se fazem dentro do fosso he a falsabraga, $\mathbf{m}^{\text {to }}$ uzada entre os Holandezes: no nosso Methodo Luzitanico $P^{\text {te }} 1^{\text {a }}$ Secção $1^{\text {a }}$ Cap $^{0} 41$ pag. 181 se faz menção dellas com bastante extenção, e diz que são as falsasbragas semelhantes ás barbacans que antigamente se fazião antes de haver 
artelheria ao pé das muralhas e torres, (de que ainda hoje se vem algumas em varias praças da Europa, e no nosso Portugal) para rezistir aos Arietes e Catapultas, maquinas com que no tempo antigo se batião as muralhas, porque recebendo ali os golpes das maquinas se preservavão os muros, enchendo para isso de terra aquelle espaço que ficava entre o muro da barbacan, e a muralha principal, porque assim ficavão estas mais bem resguardadas.

Fazem-se as falsasbragas defronte das cortinas, levantadas sobre o plano do fosso; alguns querem que tambem se haja de fazer defronte das faces dos baluartes, mas nesta parte as julga o mesmo Methodo Luzitanico com Antonio de Ville inuteys, e dão a razão de que daquella parte se não póde atirar senão para a contraescarpa, e quando se queyra atirar contra a face do baluarte opposto será tão obliquamente por sima do parapeyto, que sejão de pouco ou nenhum effeyto.

Entre ellas e a cortina se deyxa hum espaço de 35 athe 40 pes [11,55m até $13,2 \mathrm{~m}]$ alem de 15 athe 20 [4,95m até $6,6 \mathrm{~m}]$ que se The dá para grossura do seu parapeyto; mas esta largura se lhe dá em cazo de serem as muralhas de pedra e cal, por livrar os defensores que nella assistem dos estilhaços, e lascas que rezultarão no cazo de que o inimigo bata a cortina, posto que raras vezes, ou nunca sucede; mas sendo o reparo so de terra sem ser revestido de muralha bastarão 18 athe 20 pés [5,94 até $6,6 \mathrm{~m}$ ]. O seu parapeyto se póde engroçar em cazo de necessidade athe 24 pés $[7,92 \mathrm{~m}]$, dandoselhe 6 [1,98m] de alto com sua banqueta interior, com sua escarpa exterior e interior, como se da aos parapeytos dos reparos: tambem pedindo-o assim a occazião se pódera levantar a 8 ou 9 pés [2,64 ou 2,97m] fazendolhe duas ou tres banquetas, como parecer necessario. 
Logo que se vay cavando o fosso se deyxa naquella parte a terra que ha de servir para o parapeyto, por ser mais solida, e tambem por evitar a despeza que se faria sem necessidade algu'a havendo de moverse essa terra e tornarse outra vez a trazerse ao mesmo lugar para se fabricar o parapeyto.

Alguns AA [autores] não aprovão as falsasbragas havendo praça bayxa, porque dizem que o fogo que desta se fizer incomodará muyto aos defensores que na dita falsabraga estiverem: dizem outros (suppondoas muyto altas) que impedem a defença que se faz dos flancos bayxos, e ainda dos altos, mas a ambas estas objecções se responde, que como as admitimos somente elevadas seis pés $[1,98 \mathrm{~m}]$ o mais sobre o plano do fosso, nem o fogo que se faz da praça bayxa maltratará aos defensores que nella estiverem, e muyto menos impedem a defença que se faz dos flancos altos e bayxos, por the ficarem estes mais superiores.

Querem outros que se fação em roda de todo o recinto da praça, opinião que seguio o Conde de Pagan, fazendo-as tão apartadas do corpo principal da praça, que se pudessem entre ellas e a muralha fabricar cazas, e accommodar moradores como em arrebalde da praça, mas o auctor anonimo, e outros muytos dos modernos, reprovão esta forma de falsasbragas, não as admitindo mais que defronte das cortinas, sendo o principal defeyto que the notão (alem de outros mais) o ficarem as suas faces enfiadas da campanha, o que reputão por grave defeyto.

Dizem tambem os da opinião contraria as falsasbragas, que tendo o inimigo ganhado a estrada encuberta ficará superior ao seu parapeyto, e lhe fará tal offença que ninguem podera estar detraz delle, e que por tanto são de pouco serviço, e utilidade: ao que se responde, que sem embargo de que o inimigo fique superior 
na altura ao dito parapeyto, por isso mesmo de elle ficar mais bayxo o não poderá offender sem se descobrir aos defensores que estão no alto da muralha, da qual ainda que ja tenha os seus parapeytos em parte arroinados, sempre se the ha de fazer muyto danno: e como o dito parapeyto por bayxo póde mal ser batido da artelheria inimiga, contra a mosquetaria se póde reparar guarnecendo-o de saquinhos de terra, ou de cestos; e os defensores detraz delle atirando a contraescarpa debayxo para sima podem fazer as suas pontarias mais cubertos. Contra os que entrarem no fosso farão huma grande offença, e sendo necessario se póde conduzir aos flancos da dita falsabraga alguma peça de artelheria que por ficar horizontal fará muyto danno contra qualquer traveça com que o inimigo intente passar o fosso, pello que sempre a dita falsabraga he util, e necessaria, e muyto mais não havendo praças bayxas.

Demais que diante dos flancos XY no meyo do espaço que Fig. ${ }^{a} 42$ Est. 20 fica athe o refossete se podem fazer duas capoeyras enterradas como mostrão as letras $\mathrm{M}$ e $\mathrm{M}$, as quais se hirá por hu'a decida que principiará perto da serventia $\mathrm{O}$, ou tambem de dentro da falsabraga, e será cada huma destas capoeyras capaz de vinte, ou vinte e cinco mosqueteyros; e porque se não emposse nellas a agua da chuva se lhe dará vazão para o refossete: outra capoeyra se fará no sitio $\mathrm{H}$, a qual póde ter a sua entrada pello refossete; e estas tres capoeyras podem estar feytas de antemão e no tempo do sitio será util fazerem-se outras muytas em diversos lugares como adiante se dirá.

Diante das faces dos baluartes apartados dellas dez pés [3,3m] será bom fazer hum muro de sete ou outo $[2,31 \mathrm{~m}$ ou $2,64 \mathrm{~m}]$ de alto, e tres ou quatro [0,99m ou $1,32 \mathrm{~m}]$ de groço, como se reprezenta na mesma figura 42 , o qual muro servirá para entre elle 
e a muralha do baluarte se recolher o que cahir da bateria sem occupar o fosso, ficando por estorvo o dito muro para o assalto; e para melhor se faz perpendicular, e faz o mesmo effeyto que a estacada que alguns poem ao pe do reparo, e melhor ainda que a estacada, porque por detraz delle mais seguramente ainda de dia se póde recolher para dentro pellas portas falsas o entulho que cahir da muralha, e para este intento se estenderá o dito muro tanto que cubra a entrada $\mathrm{O}$ para mais segurança dos que trabalharem; e quando se não possa retirar para dentro o entulho, debayxo delle se meterão alguns barriys de polvora com seus rastos bem feytos para na occazião do assalto se fazerem voar os inimigos: nem estorva este muro que diante delle se faça huma larga capoeyra contra o portilho que o inimigo abrir na contraescarpa; e póde ser tal esta capoeyra que dentro nella se possa accommodar hu'a ou duas pessas de artelheria do genero de pedreyros ${ }^{128}$ dos que chamão de Braga que se armão sobre hu'a forquilha, ou cavalete com os quais se fará grande danno contra o dito portilho; e ficando enterradas não serão offendidas de fora, principalmente sendo as suas canhoneyras cubertas por sima com fortes vigas, com fachina e terra, por tanto espaço quanto baste para cobrir as pessas; e com este intento quando se faça o muro sobredito se lhe podem fazer a espaços arcos de tijolos cujos vãos serão tapados de pedra seca, para que sendo necessario abrir a dita capoeyra, se cave por bayxo de hum destes arcos ficando o muro como de antes fazendo o mesmo effeyto, e cobrindo a serventia e passagem da gente para a dita capoeyra, e mais serviço necessario em defença e reparação da brecha.

\footnotetext{
${ }^{128}$ Canhões que atiram com balas de pedra.
} 
A forma de desenhar as ditas falsasbragas he a seguinte.[:] Fig. ${ }^{a} 42$ Est. 20 Partase o flanco AG em tres partes iguais das quais se tirem linhas parallelas á cortina; dos pontos $\mathrm{X}$ onde a primeyra linha parallela topar com as faces dos baluartes produzidas se tirem os flancos da falsabraga XY, os quais flancos se farão perpendiculares sobre as razantes ${ }^{129}$, e em angulos obtuzos com a cortina da falsabraga, a qual cortina ha de correr parallela á da praça, e distante della quanto for a terça parte do flanco; as faces da falsabraga ficarão na mesma direytura das faces dos baluartes sem que topem nos angulos das espaldas, porque entre ellas, e os ditos angulos se ha de deyxar ficar hum espaço de dez ou doze pés [3,3m ou 3,96m] de largo para serventia para o fosso, como se ve na mesma figura notado com a letra $\mathrm{O}$.

Suposto q' o que temos dito das falsasbragas se entende ser so nos fossos secos, com tudo ainda ha alguns autores que as admitem tambem nos aquaticos, mas neste cazo será percizo [sic] levantar o seu parapeyto de sorte que fique elevado sobre o livel da agua dous ou tres pés $[0,66 \mathrm{~m}$ ou $0,99 \mathrm{~m}]$, e desta sorte vira a impedir a vista aos que estão na praça bayxa, e tambem será necessario engroçar tanto o seu parapeyto que possa rezistir ao pezo da agua, e revestillo por fora de algum muro de formigão que o não desfaça a agua, com que nestes termos me parece que será melhor não as fazer, especialmente se houver obras exteriores que são muyto melhores: quem com tudo the agradarem póde ver os diversos modos de as fazer que aponta o Methodo Luzitanico nas figuras 78 e 80, e tambem o modo de Monsieur de Vauban que aponta o Engenheyro Portuguez Estampa 10 figura 9.

\footnotetext{
${ }^{129}$ Como já foi explicado anteriormente, pelo próprio Vellozo, são as linhas imaginárias que se formam com o prolongamento das faces do baluarte até encontrar a cortina.
} 


\section{$\operatorname{Cap}^{\circ} 13 .^{\circ}$ \\ DAS CAPOEYRAS E COFRES.}

Ja no capitulo antessedente [sic] falamos em capoeyras, agora diremos o que são, donde, e para que se fazem.

Capoeyras e cofres diz o nosso Methodo Luzitanico no Cap ${ }^{\circ}$ 42 pag. 185 que são obras quazi da mesma especie das falsasbragas, so com a diferença, que estas ficão sobre o plano do fosso, e aquellas enterradas nele.

São diversos os sitios em que os AA [autores] as fazem, porque huns as querem no meyo do fosso, outros defronte dos angulos da espalda; alguns defronte dos flanqueados; ${ }^{130}$ não falta quem as fabrique nos angulos da contraescarpa, e tambem ha outros que as admitem dentro do corpo da praça nas gollas dos baluartes, e tambem no meyo das cortinas; nesta variedade eu escolhera fazellas defronte dos angulos da espalda, ficando com a frente olhando

Est. 21 para a face do baluarte opposto, como se ve na figura 43, porque neste sitio defendem a passagem do fosso, descortinão toda a sua contraescarpa, e a face do baluarte; com tudo pode haver cazo em que seja conveniente fazellas em outra parte, o que fica a eleyção do Engenheyro por cuja direcção correr a obra.

Sua forma sempre he prolongada como se ve na figura sobredita, e como dizemos no $\mathrm{Cap}^{\circ}$ antecedente que serão capazes de nellas poderem estar vinte athe vinte e cinco homens será percizo [sic] que tenhão de comprido de sessenta athe setenta e cinco pés [19,8 até $24,75 \mathrm{~m}]$, asignando tres pés [0,99m] (como he dado) para

\footnotetext{
${ }^{130}$ Os significados de ângulo flanqueado e de ângulo da espalda podem ser relembrados, para os que não estão familiarizados com a terminologia, no Cap. 6 da $1^{\underline{a}}$ Parte e na Fig. 2, Est. 1.
} 
cada soldado: de largo se the costumão dar dez pés [3,3m], e de fundo seis ou sete $[1,98$ ou 2,31m], ficando sempre dous [0,66m] deste elevado o seu parapeyto sobre o plano do fosso com suas torneyras [sic ${ }^{131}$ para jogar a mosquetaria, e sua banqueta para os defensores poderem chegar a disparar as armas; este parapeyto vay fenecer incencivelmente [sic] no plano do fosso da mesma sorte que fenece o parapeyto da estrada encuberta na explanada.

O Methodo Luzitanico pag. 186 lhe asigna so trinta pés [9,9m] de comprido, na concideração de serem so para dez mosqueteyros, e supposto nós lhe demos dobrado comprimento, e ainda mais de dobrado, he na suppozição de admitirem mais defensores; cada hum the poderá dar o comprim ${ }^{\text {to }}$ que the parecer conveniente respeytando ao numero de gente que lhe ha de meter, dando sempre tres pés $[0,99 \mathrm{~m}]$ para cada homem, com a mesma largura e profundidade.

Muytos fazem estas capoeyras cubertas por sima de taboões, os quais assentão sobre hu'a groça viga em a qual abrem hu'as torneyras [sic] como se ve na figura 44; não são peyores nesta [Est.21] forma, porque tem a conveniencia de ficarem assim os defensores amparados das bombas e granadas que o inimigo lhe póde lançar, e tambem porque não venha armado a prova de mosquete a deytar dentro nellas granadas de mão, sem embargo que diz Tensine que tem para si que de cem tiros que o inimigo a tire por acazo acertará a cahir hum dentro da capoeyra, não tendo esta mais que dez pés [3,3m] de largo; e diz mais que nem poderá chegar de perto a lan-

\footnotetext{
${ }^{131}$ Como pode ser observado em outras passagens do texto o autor, algumas vezes, comete o engano de trocar as letras de palavras, que em outras partes estão escritas corretamente. Este, também, nos parece um engano cometido com a palavra troneira, porque não encontramos a palavra torneira nos capítulos explicativos da terminologia para castramentação, que podem se encontrados em Serrão Pimentel e Azevedo Fortes.
} 
çar granadas de mão ainda que venha armado a prova de mosquete, em razão da violenta bateria que com estes se the ha de fazer, a qual quando os não mate, ao menos sempre ha de dar com elles por terra.

Com tudo sem embargo das sobreditas razões sempre he util que sejão cubertas, e não so de tabões, mais ainda em lugar destes com groças vigas que possão rezistir ao golpe, e pezo das bombas, se suceder que ali caya alguma; e ainda para melhor se cobrem por sima de terra, e se the deyxão pelos lados, e por sima entre viga e viga algumas abertas para claridade, como tambem para sahir o fumo das escorvas, que como he continuado não deyxa de embaraçar.

A melhor serventia para estas capoeyras he pelas portas falsas, sahindo destas a huma cava que se faz descuberta no fundo do fosso, porque por esta vão os soldados mais cubertos para ellas; outros lhas fazem quando ha orelhões, ou espaldas encostadas a linha do reves; seja nesta ou naquella parte, sempre se devem fazer de sorte que os defensores possão entrar, e sahir da capoeyra sem que sejão descubertos pelo inimigo.

Os cofres são outra forma de capoeyras mais pequenas, que se fazem de madeyra a prova de mosquete; quando ha pranxões de suficiente groçura estes bastão, mas quando as taboas são delgadas se lhe poem dobradas, e apartadas hu'a da outra couza de dous palmos $[0,44 \mathrm{~m}]$, e o vão se enche de boa terra bem batida, e sempre se lhe deyxão suas torneyras [sic] para os soldados poderem atirar.

Costumão fazerse no meyo das cortinas, ou nos angulos flanqueados dos baluartes, e tambem nos das espaldas, como se ve Est.22 na figura 45, notados com a letra $\mathrm{N}$; não falta quem os faça no meyo das faces, mas neste lugar como tambem nos angulos flanqueados os reprova Antonio de Ville; dando por razão que se 
não devem fazer naquellas partes que costumão ser atacadas, porque o inimigo cuydará muyto em os senhorear, e depoys servirse delles para passar o fosso como se fora galaria; e diz mais que ignora como se poderá fazer serventia para os que são fabricados nos angulos flanqueados sem que seja furando todo o corpo do baluarte, ou fazendo hum corredor por todo o comprimento do flanco e face, e assim que em o inimigo passando o fosso cortará a commonicação, ficando por este modo o cofre inutil, e talvez cortados os defensores que estiverem dentro e se não poderem retirar a tempo, e assim concorda o seu parecer com os que os fazem no meyo das cortinas, e tambem nos flancos defronte da praça bayxa o que tambem seguimos, porque os fabricados no meyo da cortina defendem ambas as faces dos baluartes de huma e outra parte, e os defronte do flanco defendem muyto bem a face do baluarte que The fica opposto, lavão toda aquella parte do fosso, e atirão contra a brecha, e tem facil serventia pela porta falsa.

Parte delles são enterrados no plano do fosso, e parte elevados sobre o mesmo plano, porque assim ficão mais cubertos da artelheria inimiga.

A sua capacidade será a que baste para poderem estar outo ou dez soldados; o nosso Methodo Luzitanico ainda admite athe doze, dando tres pés $[0,99 \mathrm{~m}]$ a cada hum, mas Antonio de Ville os não admite de mais de quinze athe vinte pés [4,95m até $6,6 \mathrm{~m}]$, e assim não ficão sendo capazes de mais de cinco athe sete defensores, mas accommodamonos mais á sobredita opinião do Methodo Luzitanico; tambem lhe faz este auctor hum fosso em roda para que o inimigo entrando no principal da praça os não possa suprender [sic] com facilidade; e guarnece toda a margem exterior deste fosso com huma estacada, cujas portas serão ferradas, 
porque com esta se dificulta mais o acesso ao inimigo: diz mais o mesmo auctor que havendo perigo de fogo se cobrirão os tays cofres com couros de boy crús que rezistem melhor que os curtidos.

Estas estacas devem ter ao menos outo ou nove pés $[2,64 \mathrm{~m}$ ou $2,97 \mathrm{~m}]$, para se poderem enterrar tres athe quatro $[0,99 \mathrm{~m}$ até $1,32 \mathrm{~m}]$, para assim ficarem seguras, de sorte que o inimigo facilmente os não possa arrancar; tambem se podem admitir athe dez pés $[3,3 \mathrm{~m}]$ de comprido, e meyo pé $[0,165 \mathrm{~m}]$ de groço, sem embargo que o dito Methodo Luzitanico lhe asigna somente hum quinto de pé $[6,6 \mathrm{~cm}]$, mas desta groçura são muy delgadas: entre huma e outra estaca se deyxa meyo pé $[0,165 \mathrm{~m}]$, ou pouco menos, para que por entre ellas não possa passar hum homem.

O fosso que asima dizemos, supposto que os AA [autores] the não determinem largura, nem profundidade, com tudo the asignamos doze athe quinze pés [3,96m até $4,95 \mathrm{~m}$ ] de largo, e seis [1,98m] de fundo, que he o que nos parece bastar.

Estas capoeyras, e cofres que temos dito não he percizo [sic] que se fabriquem logo que a praça se fortifica, porque basta que se fação na occazião do sitio, depoys de se ver a parte a que o inimigo encaminha o seu ataque; mas he forçozo que nos armazens haja toda a prevenção de pranxões, taboados, barrotes, estacas ferradas, pregos, e toda a sorte de ferramentas, e mais petrechos necessarios para a sua fabrica, e tambem q' na praça haja officiays mecanicos para a sua construcção.

Ja dissemos que os cofres que ficão nos flancos ao pé da praça bayxa tem facil serventia pela porta falsa que fica no revez do orelhão, e pella mesma se faz tambem a commonicação para o cofre do meyo da cortina (quando nestas não ha porta falsa) por hum corredor cavado no plano do fosso principal. 
Póde haver alguem que duvide e ignore o modo com que se fincarão as estacas que guarnecem a margem do fosso que se faz diante dos cofres, que por haverem de ser ferradas como se diz, e mostra a figura 46 não tem donde recebão o golpe do malho, mas Est.22 para isso se faz hum páo a que chamão os officiays mecanicos craveyra, o qual se encaxa na ponta do ferro da estaca, e recebendo este pao en si os golpes do malho, faz cravar a estaca tudo o que he necessario.

\author{
$\operatorname{Cap}^{0} 14 .^{\circ}$ \\ DAS DIVERSAS ESTACADAS \\ QUE SE FAZEM DENTRO E FORA \\ DO FOSSO.
}

Havendo tratado nos dous capitulos antecedentes das obras que se costumão fazer dentro nos fossos, não parece vir fora de seu lugar tratarmos neste prezente capitulo das diversas estacadas que dentro e fora delles se fazem, para mayor defença da praça, e embaraço do inimigo.

Fazem-se estas estacadas bem no meyo do fosso quando são aquaticos para impedirem a passagem ao inimigo quando o intente fazer em bateys, e para isso he forçozo que tenhão toda a altura da agua que tiver o fosso, e mais sete palmos [1,54m], seis [1,32m] que he forçozo tenhão cravados no fundo do fosso para sua segurança, e hum [0,22m] que hão de sobrepuchar [sobrepujar], por sima da agua; as suas pontas sempre será conveniente que sejão ferradas, ou ao menos aguçadas sendo madeyra rija; a sua grossura será de meyo pé $[0,165 \mathrm{~m}]$ ao menos, se for demais não perderá 
por isso; de menos não se admitem por delgadas: a distancia entre hu'a e outra basta hum pé $[0,33 \mathrm{~m}]$, que como he para impedir o tranzito as embarcações em que o inimigo intentar atraveçalo, não poderá conseguilo sem grande demora, ficando entretanto exposto aos tiros dos defensores.

Alguns the poem hu'a viga furada a espaços de sorte que pellos buracos encayxe nas pontas de ferro, vindo a ficar estas á superficie da agua, porque estas vigas impedem melhor a passagem as embarcações.

Sem embargo disso o Methodo Luzitanico as não aprova, dizendo que estas estacadas alem de serem de muyto custo impedem as sortidas, e tambem a entrada dos socorros que vem em bateys, e assim que he melhor de espaço a espaço meter hu'as estacas groças ferradas com as pontas agudas, e pôr de hu'as a outras cadeas de ferro fortes, porque estas impedem o tranzito ao inimigo, e quando he necessario se tira huma destas para se passar pello espaço entre huma e outra estaca, que póde ser de dez athe doze pés $[3,3 \mathrm{~m}$ até $3,96 \mathrm{~m}]$, athe catorze $[4,62 \mathrm{~m}]$ o mais, e que são por este modo de menor despeza; a forma destas estacadas com corEst. 22 rentes se mostra na figura 47.

Tambem nos fossos secos se fazem estas estacadas, mas mais Est. 23 chegadas a muralha como se mostra na figura 48, para por meyo dellas se impedirem as entreprezas, poys senão poderá dar o assalto sem primeyro se romper a estacada, e para que o inimigo não consiga isto com facilidade será conveniente que sejão fortes, e bem cravadas, e só com meyo palmo $[0,165 \mathrm{~m}]$ de vão entre huma e outra estaca, e tambem com as pontas ferradas.

Quando ha refossetes se lhe faz da mesma sorte huma estacada na margem exterior, da mesma altura e grossura que a que 
fica asima dita, porque embaração muyto ao inimigo a sua passagem, e lhe fazem perder tempo, e ficarem expostos aos tiros da praça em quanto não se desembaração daquelle obstaculo.

Alem das estacadas que temos dito se fazem em diversas partes dentro dos fossos se praticão outras no meyo das estradas encubertas, de tal altura que só sobrepuchem [sobrepujem] as suas pontas por sima do parapeyto, para que não sejão vistas, nem batidas da campanha.

O nosso Methodo Luzitanico no Scholio ao Cap ${ }^{\circ} 33$ da $1^{\text {a }}$ parte secção $1^{\mathrm{a}}$ pag. 141 quer que se fação somente seis pés $[1,98 \mathrm{~m}]$ afastadas do parapeyto, porque entrando o inimigo na estrada encuberta não tenha largueza para se revolver.

Por dentro destas estacadas se lhe costuma pôr hu'a cinta ou facha pregada de largura de meyo pé $[0,16,5 \mathrm{~m}]$, ou ao menos de dous quintos de pé $[0,12 \mathrm{~m}]$, a qual serve não so para fortificar mais a dita estacada, mas para por sima della atirarem os defensores, descançando sobre ella as armas.

Faz se tambem outra estacada sobre o arcem $^{132}$, ou explanada afastada do parapeyto som $^{\text {te }}$ tres pés $[0,99 \mathrm{~m}]$, para que commodamente possão os soldados atirar por entre ellas, e defendelas com dardos ou outras armas; a sua altura nunca excederá de quatro pés $[1,32 \mathrm{~m}]$; a grossura ao menos sera de dous quintos de pé $[0,12 \mathrm{~m}]$; e outro tanto será a distancia que se deyche entre hu'a e outra estaca; as suas pontas se farão agudas, no cazo que não haja meyos de se ferrarem.

O auctor do Methodo Luzitanico no Scholio atraz citado as não aprova, porque diz que não estão livres do inconveniente de

${ }^{132}$ Daí deve ter-se sido originada a palavra aceiro ou terreno desbastado de vegetação em torno de uma propriedade. 
se poder o inimigo cobrir com ellas encostando-lhe fachina e terra, e traz por exemplo o que fes o Marquez de Caracena no sitio que pôs ao castello de Villa Viçoza, mas a isto se responde que estas estacadas não se fazem se não em praças pequenas de limitada guarnição para evitar alguma escalada repentina, porque em praças reays não são necessarias.

Ultimamente se fazem outras estacadas no corpo da muraTha a que chamão pentens [pentes], cravadas de sorte que fiquem perpendiculares ao corpo da muralha, parte cravadas nella, e parte que ficão no ar, o seu comprimento quer o Methodo Luzitanico que seja de seis pés $[1,98 \mathrm{~m}]$ para entrarem tres $[0,99 \mathrm{~m}]$ na muralha, e ficarem os outros tres de fora; o Engenheyro Portuguez os admite de dez palmos [2,2m], quatro [0,88m] para fóra; Pfeffinger ainda os estende athe outo pés $[2,64 \mathrm{~m}]$, parecer com que nos conformamos, por impossibilitarem assim melhor as escalladas, que he o principal fim porque se fazem, e tambem para evitarem a fuga dos soldados da praça, especialmente quando o reparo não he revestido de muralha de pedra e cal, porque sendo de terra, como he força tenha mayor escarpa, facilmente, e com qualquer leve ajuda se lanção por ella abayxo.

O sitio mais proprio em que estes tays pentens se accommodão são sobre o corpo da muralha a raiz do parapeyto, porque nesta parte fazem conseguir melhor o fim para que se fazem. Não falta quem os queyra aos dous terços da altura da muralha, mas aqui não são tão proprios.

Querem tambem alguns auctores que os haja por baixo dos parapeytos das praças bayxas, e Antonio de Ville he de parecer que tambem se ponhão nas obras exteriores, que como estas sejão comumente de terra, e bayxas, e por tanto faceys de escalar, 
servem nesta parte (como tambem nas mais) de evitar as entreprezas, e o dezertarem os soldados como ja temos dito.

A toda a sorte de estacadas que temos dito se fazem assim dentro do fosso, como na estrada encuberta; e sobre a explanada se lhe fazem suas portas em forma de cancelas que se fechão por dentro com ferrolhos e chaves, e terão varias de espaço a espaço, para melhor se poderem retirar os defensores quando sejão percizados [sic] a fazello.

A madeyra para todas ellas sempre se procurará seja da mais duravel; na Europa he o carvalho, e o pinho, mas este so para as dos fossos aquaticos por se conservar incorrupta debayxo da agua: neste paiz da America em que escrevemos sendo que haja necessidade de se fazerem, não faltão madeyras de boa qualidade, e muyta duração.

$$
\text { Cap. }^{\circ} 15 .^{\circ}
$$

DAS PORTAS, TRANZITOS ${ }^{133}$, E PONTES.

Todas as praças uniformemente necessitão de portas para serventia da guarnição e moradores, humas mais, outras menos, porque as de mediana grandeza lhe bastarão duas, hu'a em correspondencia da outra, mas as praças a que legitimamente se póde dar o nome de reays, e que tem de outo baluartes para sima não lhe bastão menos de tres, muytas ha que tem quatro, e outras cinco, de que não faltão exemplos na Europa.

${ }^{133}$ O termo tranzito significa, no caso, a circulação, geralmente coberta por abóbada de berço, que vai da porta de entrada da fortaleza até o pátio. Está, quase sempre, ladeado pelos alojamentos da guarda: corpos de guarda que costumão ter aos lados, como diz Vellozo textualmente mais adiante. 
Fazem-se no meyo das cortinas, por ser o lugar mais proprio para ellas, ou tambem mais encostadas a hum que a outro flanco, e dá a razão o Methodo Luzitanico no Cap. 35 pag. 147 para que fiquem fronteyras a alguma rua da praça, o que sempre se deve procurar por evitar o perjuizo [sic], e dispendio de demolir idificios [sic].

Não falta quem fizesse as portas nas faces dos baluartes, e tambem nos flancos, mas em qualquer destas partes tem muytos incomodos, e so se poderião admitir nelles por alguma urgente necessidade.

A sua fabrica deve reprezentar robustês, e valentia, e por isso escolherão os Architectos a ordem Toscana, por ser a mais valente das cinco ordens da Architectura civil; outros admitem a Dorica, porque alem de se compor de partes fortes e robustas, tem mais galhardia, e são mais aparatozas ${ }^{134}$.

Varias são as medidas que lhe asignão os AA [autores] na sua largura e altura, porque Adão Fritach quer que o vão das portas em praças reays sejão de dez athe doze pés Geometricos [2,78 até $3,33 \mathrm{~m}$ ] e catorze athe quinze [3,89 até $4,17 \mathrm{~m}$ ] de alto, entrando o vão do arco; Mathias Dogen as faz de doze de largo [3,33m], e outro tanto de alto (terão pouco de fermozas) Fournier, e Rojas o mesmo que Fritach, mas tem a differença, que aquelles auctores fallão de pés Geometricos, e este de Rinthlandicos. Medina Barba as faz de dez pés Geometricos [2,78m] de largo, e treze e meyo de alto [3,75m]; Glodman [Goldman] lhe dá mayor largura e altura que nenhum outro auctor, porque lhe asigna treze pés Rinthlandicos $[4,01 \mathrm{~m}]$ para a largura, e a altura em proporção sexquialtera, que são dezanove e meyo $[6,02 \mathrm{~m}]$, não ha duvida

\footnotetext{
${ }^{134}$ Estas considerações simbólicas das ordens remontam ao tempo de Vitrúvio e passa pelos tratadistas do Renascimento sendo sempre lembrada pelos engenheiros militares.
} 
que serão vistozos, mas ficão demaziadamente altos em razão da mais obra que levão por sima da volta do arco, e será necessario que o liminar ou soleyra desça muyto abayxo do livel do terreno natural da praça.

O Methodo Luzitanico no referido capitulo 35 pagina 148 The asigna outo athe dez ou onze pés Portuguezes [2,64 até 3,30 ou $3,63 \mathrm{~m}]$, e sua altura de doze athe catorze [3,96 até 4,62m], e isto ainda regulando a grandeza da praça, e altura das muralhas.

Finalmente o nosso Engenheyro Portuguez lhe dá doze athe dezaseis palmos [2,64 até 3,52m] de largo, e a sua altura em proporção sexquialtera ${ }^{135}$, que he dezouto athe vinte e quatro palmos [3,96 até $5,28 \mathrm{~m}]$; nesta variedade digo que se fação de quinze palmos de largo $[3,3 \mathrm{~m}]$, e vinte $[4,4 \mathrm{~m}]$ de alto, que he hum terço mais de sua largura, ou em proporção sexquitercia ${ }^{136}$, porq' assim não incorrerão no defeyto de muyto altas, nem tambem no de pouco vistozas.

O limiar [liminar] ou soleyra destas portas sempre deve ser dous palmos $[0,44 \mathrm{~m}]$ ou dous e meyo $[0,55 \mathrm{~m}]$ mais bayxo que o livel da campanha, para que assim fiquem menos expostas as baterias inimigas, que cuyda muyto em ver se as pode romper.

A madeyra para as portas será de boa qualidade, e de groçura de meyo palmo $[0,11 \mathrm{~m}]$ ao menos, ou de dous terços de palmo $[0,14 \mathrm{~m}]$, e ainda são por dentro forradas com taboado da mesma qualidade de grossura de dous dedos, e atraveçado de sorte que cada taboa de persi prenda todos os pranchões que ficão ao alto; por fora são todas as juntas chapeadas com barras de ferro ao alto de largura de tres dedos,

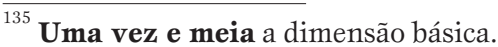

${ }^{136}$ Como o autor mesmo explica é uma vez e um terço a medida básica que é a largura da portada.
} 
ou pouco menos, e pregadas de palmo a palmo com pregos de cabeça redonda e grande, algum tanto ouvada; costumão levar dous ferrolhos fortes e groços, o primeyro quazi na altura de meya porta, o segundo mais abayxo, de sorte que prenda hum postigo que se faz em huma das meyas portas; o uso destes postigos ${ }^{137}$ he para q' antes de se abrirem as portas, e se franquear a entrada aos payzanos que querem entrar, ou sahir aos seus tratos, se botar por elles huma patrulha fora que vay reconhecer todo o contorno da praça, e examinar se ha nelle inimigo emboscado, ficando entre tanto a guarda postada sobre as armas, e reconhecendose que está a campanha limpa e dezembaraçada de inimigo, então se abrem as portas todas: tambem se fazem estes postigos para se abrirem de noute em algum incidente forçozo, mas como em outra parte havemos de tratar mais miudamente do uso destes postigos, então diremos o mais; a sua altura costuma ser de tres athe quatro pés $[0,99 \mathrm{~m}$ até $1,32 \mathrm{~m}]$, e a a largura de dous $[0,66 \mathrm{~m}]$, que he o que basta para entrar e sahir hum homem commodamente.

Fazem alguns por sima destes tays postigos outros atraveçados da altura de meyo pé $[0,165 \mathrm{~m}]$, e do comprimento que couber em cada hu'a das meyas portas, para no cazo do inimigo querer forçar a porta ou arrumar petardo se poder por elles defender com os mosquetes.

Por dentro se segurão estas portas com duas trancas que correm por dentro do groço da muralha, e na hora de fechar as portas se correm por hu'as argolas de ferro que tem nas cabeças pregadas, e se apertão com cunhas; a grossura destas trancas será de dous terços de palmo $[0,146 \mathrm{~m}]$, as quadradas são melhores que as redondas.

\footnotetext{
${ }^{137}$ São pequenas portas que se fazem na porta maior de uma fortaleza, para que se avite a abertura das portas pesadas para a passagem de poucos membros da guarnição.
} 
Os tranzitos das portas para dentro das praças se fazem sempre mais largos que estas outro tanto como a metade de sua largura, ou pouco mais, isto he que tendo a porta quinze palmos [3,3m] de largo como lhe asignamos, terá o tranzito vinte e dous e meyo, athe vinte e quatro $[4,95 \mathrm{~m}$ até $5,28 \mathrm{~m}]$; o seu comprimento he toda a largura do terrapleno, cuberto por sima de abobeda de hum tijollo ao alto ${ }^{138}$ nas paredes das ilhargas se lhe fazem suas frestas amiudadas de dous palmos $[0,44 \mathrm{~m}]$ de largo pella parte do tranzito, e hum quarto de palmo $[5,5 \mathrm{~cm}]$ pella parte interior dos corpos de guarda que costumão ter aos lados, como logo diremos; a sua altura póde ser de outros dous palmos athe dous e meyo [0,44m até $0,55 \mathrm{~m}]$ o mais.

Fazem se estas frestas para que no cazo que o imigo [inimigo] chegue a entrar no tranzito possa dellas ser combatido; deve advertir-se que não fique hu'a defronte da outra, mas desencontradas, para que livremente possão os soldados atirar sem que se offendão huns aos outros.

Muytos fazem estes tranzitos direytos como se ve na figura Est. 23 49 , outros se fazem em volta, de sorte que a porta interior fique toda desencontrada da exterior, para que no cazo que o inimigo chegue a arrumar petardo, não leve este ambas as portas, e assim são julgados estes por melhores, mas esta volta redonda não principia logo do pé da muralha, senão depoys de correrem as paredes do tranzito direytas por espaço de dez athe doze pés [3,30 até $3,96 \mathrm{~m}]$, dahi por diante se leva em volta athe o fim, como se reprezenta na figura 50 .

${ }^{138}$ Azevedo Fortes, quando trata de abóbadas resistentes a bombas, recomenda abóbadas reforçadas, mais espessas, de tijolos, como desenhamos no nosso texto sobre As fortificação portuguesas de Salvador, p. 164 e não tão singelas como sugeridas por Vellozo. 
A porta interior algum auctor ha que a faz direyta com sua verga por sima; outros a fazem de arco, e isto he o mais seguido, mas lizo sem ornato nenhum; da mesma sorte as portas de madeyra são de menos fabrica e grossura que as exteriores, porque não necessitão de tanta fortaleza, e se fechão com hum so ferrolho pella parte exterior da praça, nem nestas portas se fazem os postigos que dissemos nas outras.

No meyo destes tranzitos se costumão fazer huns encarnes de pedra de cantaria que correm por toda sua altura, e tambem pella volta da abobeda, servem para por elles sobirem e decerem os orgãos, ou rastrilhos (adiante diremos o que são, e o de que servem). O Methodo Luzitanico os quer logo immidiatamente a entrada da porta principal, de sorte que esta nem pouco, nem muy aberta possa impedir o seu uso, mas sendo nesta parte não dão lugar a que o inimigo possa ser offendido das frestas, e de sima da abobeda, e assim julgo serem melhores mais apartados da porta principal, porque entrando o inimigo nessa parte do tranzito que fica entre o dito rastilho, e a porta prinicipal, receberá grande danno dos defensores que estão dentro dos corpos de guarda, e tambem em sima da abobeda, na qual se deyxão quando se fabricão varios buracos feytos em pedras que se metem na mesma abobeda entre os tijollos, pelos quais buracos se lanção granadas de mão, panellas de polvora, bombas, e outros artificios de fogo, que incomodão notavelmente ao inimigo que ali chegou a entrar.

Estes buracos se fazem de varias formas, os melhores são redondos; o Methodo Luzitanico parte $1^{\text {a }}$ Cap. 36 pag. 153 quer que estes buracos sejão mais estreytos na parte inferior, e mais largos na superior, dando de diametro a esta dous pés e meyo $[0,825 \mathrm{~m}]$, e hum pé a inferior $[0,33 \mathrm{~m}]$, mas temos estas medidas 
por demaziadas, e assim julgamos que na parte superior bastão dous palmos $[0,66 \mathrm{~m}]$, e na inferior hum palmo $[0,33 \mathrm{~m}]$, o mais hum e hu'a polegada $[2,75 \mathrm{~cm}]$, por onde cabe hu'a suficiente bomba, ou panella de polvora; sempre se fazem mais altos que a grossura da abobeda, para que fiquem as suas bocas mais elevadas que a superficie superior da abobeda, e no tempo da paz estão tapadas com qualquer taboa.

Fazem-se tambem logo ao entrar da porta ao pé da muralha em toda a sua largura interior huas covas, ou fojos de altura de seis pés $[1,98 \mathrm{~m}]$, e outo $[2,64 \mathrm{~m}]$ de comprido, os quais se fechão com duas portas a modo de alsapão, que abertas encostão as paredes do tranzito, e fechadas descanção sobre dous pilares de pedra que ha dentro nos ditos fojos; estas portas de dia estão fechadas, mas de noute se abrem, e levantão por humas argolas de ferro que tem no meyo, ou nas cabeças, e neste lugar podem ser duas, hu'a em sima, outra embayxo, nas quais se prendem huns cabos pelos quais com muyta facilidade se levantão e abayxão: tem estas portas ou alsapões seus lemes ou dobradiças fortes que pregão em hu'a viga que se assenta e segura no pavimento do tranzito; advirtase que estas portas devem ser de boa groçura para poderem com o pezo dos carros que entrão e sahem da praça carregados.

No fundo deste fojo se cravão humas estacas da groçura de tres athe quatro polegadas $[8,25 \mathrm{~cm}$ ate $11 \mathrm{~cm}]$, e de quatro palmos [0,88m] de alto, com as pontas ferradas, e bem aguda; na occazião se tem as portas destes fojos levantadas, e sendo que o inimigo intente forçar a porta como o faz com percipitação [sic], cahem muytos nos ditos fojos, e mizeravelmente morrem cravados nas pontas das ditas estacas, sem que os seus lhes possão valer. 
Resta dizermos que o resto do pavimento do tranzito se faz em ladeyra sobindo para dentro da praça, tudo quanto o liminar, ou soleyra da porta deceu para bayxo do livel do terreno natural, de sorte que venha a fenecer nelle sem degrao, por razão dos carros não darem esse salto.

Advirtase que nos fossos aquaticos não so se deve assentar a soleyra do livel da agua para sima, mas tanto mais alta quanto baste para que as aguas do inverno não cheguem a sobrepuchar [sobrepujar] por sima, e entrem pello tranzito dentro, e talvez cheguem a inundar a praça, especialmente se o fosso recebe agua corrente.

Resta dizermos das pontes as quais são feytas de madeyra na forma seguinte, segundo as descrevem varios auctores: o seu comprimento he toda a largura do fosso; na sua largura varião os auctores; mas o comum he que por ellas possão passar dous carros ao mesmo tempo, hum entrando outro sahindo, sem que se encontrem, e para isto diz o nosso Methodo Luzitanico Cap ${ }^{\circ} 39$ pag. 160 que the parece bastão catorze ou quinze pés Portuguezes $[4,62 \mathrm{~m}$ ou $4,95 \mathrm{~m}$ ], o que he suficiente largura.

Querem alguns (e não sem bom fundamento) que dentro do fosso se armem huns groços e fortes cavaletes de madeyra de boa Est.2[5] duração como se reprezenta na figura 51, sobre os quais se assentem groças vigas de carvalho, ou outra madeyra duravel, sobre as quais se atraveção pranxões tambem de boa qualidade de madeyra de quatro polegadas de groço, pregadas ou cavilhadas com cavilhas da mesma madeyra, ou de outra ainda mais rija; e os ditos cavaletes se lhe assentão os pés sobre lages, ou sobre alvenaria para os livrar de que com a humidade da terra se corrompão [sic], e aprodeção [sic] depreça; e tambem se escorão com boas escoras postas ao viez para sua mayor segurança, poys por estas pontes 
passão couzas de muyto pezo, como seja artelheria groça, carros de monições e mantimentos, cavalaria, e tudo o mais de que tem necessidade hu'a praça de guerra.

$\mathrm{O}$ bom fundamento (como assima dissemos) com que assim as fabricão alguns auctores, he para que sendo forçozo (como succede muytas vezes) desmancharem-se porque o inimigo se não sirva dellas contra a praça, se possa consiguir com muyta facilidade, e em breve tempo, e ainda aproveytarse a madeyra para tornar a servir. Pelos lados se lhe fazem suas guardas (a que neste paiz chamão corrimões) para a gente não cahir no fosso; basta que tenhão dous pés ou dous e meyo de altura [0,66 ou $0,82 \mathrm{~m}]$, e ainda athe tres $[0,99 \mathrm{~m}]$.

Querem outros que estes postes ou cavaletes sejão fichos [fixos], para o que cravão no fundo do fosso cinco madeyras groços (aqui lhe chamão esteyos) tres aplumo que são os do meyo, e os dous hum de cada banda que servem de escoras aos outros; sobre as cabeças destes esteyos se assentão madres de grossura de dous palmos em quadro com encarnes ${ }^{139}$ a meya madeyra, que encayxão nas cabeças dos esteyos em que se tem feyto mechas; entre a primeyra ordem destes esteyos e a segunda, se deyxão quinze athe vinte palmos [3,3m até $4,4 \mathrm{~m}]$ de vão somente, e no mais quanto as vigas e pranxões se obra como asima se tem dito.

Ainda o nosso Engenheyro Portuguez quer que sobre o pavimento destas pontes se deytem cinco ou seis polegadas [13,75cm ou $16,5 \mathrm{~cm}]$ de saybro ${ }^{140}$ para sobre elle se calçar de seyxos miudos, porque diz que

\footnotetext{
${ }^{139}$ Rebaixos para ensamblar peças de madeira.

${ }^{140}$ O vocábulo saybro [saibro] tem algumas variações semânticas de lugar para lugar. Parecenos, entretanto, em função da leitura de certos textos e documentos portugueses dos séculos XVII e XVIII, que o significado era o mesmo que usamos atualmente na Bahia, isto é, um solo do tipo "arenoso", muito usado para fazer argamassas "de barro", onde o argilomineral predominante é a caulinita sendo, por isto mesmo, mais estável e com pequenas variações dimensionais na secagem.
} 
assim fica a ponte mais capaz de sustentar grandes pezos, e ter boa duração; antes de se lançar o saybro adverte que se alcatroem os pranxões, e que as guardas ou corrimões sejão oleadas ao menos de dous em dous, ou de tres em tres annos, para terem mais duraçã ${ }^{141}$ : pellas ilhargas dos pranchões em todo o seu comprimento se the poem huns bordos de altura das mesmas cinco ou seis polegadas para sustentarem esta tal calçada, e não se desmancharem com a continuação da passagem.

Sendo que se fabriquem nesta forma será $\mathrm{m}^{\text {to }}$ conveniente que os esteyos se lhe queyme tudo o que hão de entrar na terra ${ }^{142}$, e ainda hum palmo $[0,22 \mathrm{~m}]$ mais, e se alcatroem tambem, porque desta sorte mostra a experiencia que se conservão bem de bayxo da terra sem corrupção.

Muytos em lugar destes esteyos the fazem pilares de pedra ou tijollo, o que sem duvida he de mais duração que os esteyos de páo, e como se podem na occazião derribar facilmente os não regeytamos.

Não faltou quem em algumas praças as fizesse todas de pedra, não se póde negar que são mais vistozas, e de muyto mayor duração, mas fazem muyto mayor despeza, e são perjudiciays [sic], porque se póde o inimigo encobrir com ellas; e sendo que haja tempo para se demolirem sempre entulhão o fosso, razões porque hoje não são admitidas.

Estas pontes que temos descripto se chamão dormentes, e principiando sobre a contra escarpa do fosso donde as pontas das suas vigas são embebidas, não chegão a soleyra da porta, mas ficão apartadas della couza de doze pés [3,96m], porque daqui athe a porta

\footnotetext{
${ }^{141}$ Observar que a madeira ao relento era tratada com óleo ou alcatroada para ter maior duração. Tivemos a oportunidade de encontrar em uma das cortinas do Forte de São Pedro manchas de alcatrão que possivelmente foi utilizado para tratar os reparos (carre tas) da aua artilharia.

${ }^{142}$ É uma prática que é ensinada desde Vitrúvio e que, até hoje, é muito empregada nas regiões rurais para proteger postes e estacas fincados no terreno.
} 
se faz outra ponte mais estreyta a que chamão levadiça, porque se levanta e abayxa todas as vezes que he necessario; estas tays pontes levadiças se fazem tão fortes como as dormentes, sobre quatro traves que de hu'a e outra parte prendem em barrotes de hum palmo em quadro $[0,22 \times 0,22 \mathrm{~m}]$, e sobre as ditas traves assentão os pranxões tão groços como os da ponte principal, pregados ou cavilhados como elles, mas esta ponte levadiça não costuma ter corrimões.

Os barrotes sobre que se fazem fichas [fixas] as ditas traves terão de cada parte mais hum palmo $[0,22 \mathrm{~m}]$ de comprido do que tiver de largo a ponte levadiça; o primeyro barrote que ajusta com a ponte dormente, e assenta sobre a primeyra madre a meya madeyra será quadrado em quina viva, e nas pontas que excedem a largura da ponte se lhe pregão humas argolas de ferro groças para nellas prenderem as cadeas porque se levanta a dita ponte levadiça; as pontas do segundo barrote que fica encostado a soleyra da porta serão redondas para encayxarem em humas cavas tambem redondas que se fazem em huns cachorros de pedra que ficão aos lados dos pés direytos do arco da porta, e na mesma altura da soleyra, para nelles se moverem em forma de eyxo, quando se quer levantar ou abayxar a ponte como se tem dito. Advirtase que se a ponte dormente for por sima calçada de sexos como dizemos asima, que esta levadiça o não será, em razão do grande pezo com que ficaria e se não poderia levantar com facilidade, como muytas vezes he necessario, mas será percizo [sic] que fique mais alta para igualar com a dita parte dormente.

Varios são os engenhos porque se costumão levantar e abayxar estas pontes levadiças, como aponta o nosso Methodo Luzitanico Cap. ${ }^{\circ} 39, \S 3 .^{\circ}$ pag. 165 , mas o mais commum he o de frechas, e o mais uzado por mais faceis. 
São poys as frechas huns paos compridos vinte pés $[6,6 \mathrm{~m}] \mathrm{o}$ menos; de groçura de hum palmo [0,22m] esforçado no meyo, mas para as pontas se adelgaça de sorte que fique em dous terços de pe $[0,22 \mathrm{~m} \text { ou um palmo }]^{143}$; no meyo se lhe poem hum eyxo redondo da groçura de meyo palmo $[0,11 \mathrm{~m}]$ reforçado, o qual encayxa em huns cachorros de pedra que ficão por bayxo da abobeda, embebidos na muralha athe o meyo, no mesmo livel das frestas: no portal se deyxão huns claros a que chamão frestas, que principião sobre os seguintes do arco, e vão athe asima abertos; servem para por elles andarem as ditas frechas livremente; nas pontas exteriores se the fazem fichas [fixas] hu'as cadeas de ferro groças, as quais terão nas pontas huns gatos tambem de ferro que prendem nas argolas q' asima dissemos se poem nas cabeças do primeyro barrote; estas cadeas terão de comprido o que baste para que bayxa a ponte levadiça fiquem as frechas assentadas no plano da fresta, e parallelas ao orizonte: as cabeças interiores destas frechas se prendem de hu'a a outra com hum barrote para não jogarem e se lhe poem outras correntes mais curtas pelas quais se abayxão as ditas frechas quando a ponte se quer levantar; alguns the fazem ficha [fixa] no meyo do barrote que prende as frechas hu'a so corrente, mas esta não he a que basta para com facilidade se levantar e abayxar a ponte levadiça: quem quizer ver outros modo [sic] consulte o Methodo Luzitanico no referido Cap $^{\circ} 39$ onde achará varios.

Tambem se costumão fazer outras pontes levadiças no meyo das dormentes, e tambem logo no principio junto a contraescarpa

\footnotetext{
${ }^{43}$ Existe uma incongruência no texto desta frase entre a descrição e os valores indicados. Se a peça tem no meio o valor de 1 palmo $[0,22 \mathrm{~m}]$, mas para as pontas se adelgaça, não pode ter dous terços do pé $[0,22 \mathrm{~m}]$ na extermidade porque corresponde ao mesmo valor. Ou o valor inicial é de um pé ou então o segundo é $\mathbf{2} / \mathbf{3}$ de um palmo. A palavra esforçado significa reforçado.
} 
do fosso, mas isto he so nas praças mediocres, que tem limitada guarnição, a qual he percizo [sic] não fatigar com muytas guardas; mas nas praças reays que se suppoem bem guardadas, e não temem entreprezas, se não costumão fazer.

As pontes para os revelins, ou outra alguma obra exterior com que se cubrão as portas principays supposto sejão mais curtas nem por isso devem ser menos fortes, poys por ellas passa tudo o mesmo que pelas outras, e assim devem ser obradas com as mesmas circunstancias que as da praça, para terem a duração necessaria.

Tambem quando se fazem as pontes levadiças no meyo das domentes, se lhe costumão fazer huns corpos de guarda pella parte interior, a hum lado da ponte sobre esteyos particulares de hum pé $[0,33 \mathrm{~m}]$ de groço, sobre os quais se traveja, e asoalha de taboado ordinario; e com o mesmo se lhe formão as paredes, para na occazião poderem ser demolidas com facilidade, ou queymadas, quando se não podem desmanchar.

O comprimento destes corpos de guarda será de vinte palmos $[4,4 \mathrm{~m}]$ o mais, e a sua largura de quinze [3,3m], para poder levar sua tarima ${ }^{144}$; a altura a esta proporção, e o seu pavimento ficará justamente no livel do da ponte. Alguns os fazem apartados algum tanto da ponte principal, e com commonicação para ella por outra pontezinha de largura e comprimento de quatro pés $[1,32 \mathrm{~m}]$, mas tenho esta tal pontezinha por escuzada, como tambem o he o mesmo corpo da guarda havendo revelim que cubra a porta.

\footnotetext{
${ }^{144}$ Atualmente o termo mais conhecido entre nós é tarimba, que quer dizer cama ou estrado de dormir para o soldado. O termo arcaico tarima, porém, está mais ligado à sua origem árabe que quer dizer o mesmo.
} 


\section{$\operatorname{Cap}^{0} 16 .^{\circ}$ \\ DOS RASTRILHOS, E ORGÃOS.}

No capitulo antecedente falamos muyto de passagem nos rastrilhos ${ }^{145}$ e orgãos, agora neste capitulo como em seu proprio lugar diremos o que são, e o de que servem.

Os rastrilhos são os primeyros que tiverão o uzo nos tranzitos das portas, e assim são antiquissimos; a sua forma he de duas maneyras, a primeyra de grade como de ferro, a segunda como de cansela, ou seja com os barrotes ao alto, ou com elles atraveçados, como tudo se

Est. 26 mostra nas figuras numero 52, são feytos de boa madeyra de grossura de meyo pé $[0,165 \mathrm{~m}]$; sua altura será tanta que deyxados cahir fechem todo o vão do tranzito athe asima da abobeda, sobre a qual se armão huns sarilhos por força dos quais se levantão e abayxão os ditos rastrilhos, e ficão dentro de huma caza que para isso se faz em sima da abobeda; as pontas dos páos que ficão ao alto serão ferradas, e agudas, de sorte que possão encayxar em huns buracos que se fazem no pavimento do tranzito em humas lages que nelle se metem: querem alguns que todo este rastrilho seja chapeado de ferro, cravado com pregos groços, porque desta sorte são mais fortes, e rezistem mais ao fogo, se o inimigo os intentar queymar; os de forma de cansela são melhores que os outros, especialmente dos que são feytos com os páos atraveçados, que de nenhuma sorte admitimos: os que são feytos com paos ao alto sempre carecem de hum barrote em sima, outro em bayxo que os prenda para que não joguem, entalhados a meya madeyra, porque se forem sobre postos carecerão de ser muyto largos os encayxes de pedraria que se fazem embebidos nas paredes dos

\footnotetext{
${ }^{145}$ Isto vem a ser uma porta guilhotina que se abre e se fecha movimentando-se para cima e parabaixo.
} 
lados, como ja dissemos no capitulo antecedente, e da mesma sorte a abertura da abobeda, o que se escuza, fazendose na forma referida.

Tambem devem ter as pontas ferradas, e serão os páos desta forma de rastrilhos ao menos de hum palmo [0,22m] de groço, e chapeados de ferro podendo ser para o fim que temos dito, e tambem para que fiquem bem pezados de sorte que possão tanto estes como a outra forma de rastrilhos ja explicada quebrar qualquer substentaculo que o inimigo the chegue a meter de bayxo, como se tem visto repetidas vezes em que se conseguirão as entreprezas, permiditadas [premeditadas], e neste cazo se deyxão cahir de pancada, para com a violencia desta fazerem em pedaços o que se lhe meter debayxo, o q' não bastou na entrepreza de Amiens sem embargo de que o rastrilho quebrou, e afundou em parte o carro que lhe meterão debayxo, porque chegando o socorro destinado entrou e rendeu a praça.

Bonajuto Lorine quer que haja segundo rastrilho no fim do tranzito pouco distante da porta interior, o que aprovão varios auctores, e com elles o nosso Methodo Luzitanico, porque em quanto o inimigo trabalha em romper o primeyro rastrilho, ha tempo para acodirem os defensores a reforçar os corpos de guarda, e a sobirem aos terraplenos, e a defenderem a porta, ficando por este meyo desvanecida a entrepreza intentada.

Com tudo os modernos ensinados da experiencia desprezarão estas formas de rastrilhos, e inventarão outros a que chamarão orgãos; são estes huns páos soltos, tão compridos que ainda que o inimigo os chegue a cortar, sempre venhão abayxo, sem nunca sahirem do groço da abobeda; devem ser de madeyra forte e duravel com hum palmo em quadro $[0,22 \mathrm{~m} \times 0,22 \mathrm{~m}]$ o menos de groço, as suas pontas tambem devem ser ferradas na forma que temos dito dos rastrilhos, para 
encayxarem ao cahir em huns buracos que se fazem no pavimento do tranzito, como ja se disse para os rastrilhos. No alto da caza em sima da abobeda se faz ficho [fixo] hum páo redondo em duas colunas de pedra, com seus encarnes tambem redondos em que o dito páo redondo possa encayxar, e voltar livremente, para o que se lhe poem em hu'a das cabeças hu'a roda por força da qual se faz voltar o dito páo, no qual se fazem fichos [fixos] os cabos que prendem em argolas Est.26 pregadas nas cabeças dos páos, o que tudo se reprezenta na figura 53.

Tambem para mayor segurança e cahirem os ditos páos a plumo se fazem fichas [fixas] por bayxo da abobeda nas paredes do tranzito duas traves, distantes hu'a da outra quanto baste para que os páos possão cahir e levantarem-se folgadamente sem embaraço com se ve na figura 53: a distancia em que devem ficar os páos huns dos outros, he somente de meyo pé $[0,165 \mathrm{~m}]$, e nada mais.

Toda a razão que os auctores modernos tiverão para fabricarem nesta forma os chamados orgãos, he porque sucedendo que o inimigo consiga o porlhe algum substentaculo debayxo para que não venhão de todo abayxo, suceda isto so nos que apanhar o tal impedimento, mas os mais sempre venhão abayxo e fechem o tranzito, e por esta so razão he este invento hoje abraçado de todos.

\author{
$\operatorname{Cap}^{0} 17^{\circ}$ \\ DOS CORPOS DE GUARDA QUE \\ SE FAZEM ENCOSTADOS ÁS PAREDES DO TRANZITO
}

Fazem-se os corpos de guarda respeytando a capacidade da praça, porque em hu'a real que tem guarnição grande, necessita percizamente [sic] de ser grande, mas em hu'a praça mediocre, 
ou pequena basta que sejão pequenos, ou de mediana grandeza, em razão da menor guarnição que estas praças costumão ter; nos tranzitos que são direytos se fazem as suas paredes parallelas as do dito tranzito, deyxandose primeyro hum corredor de outo pés [2,64m] de largo, o qual mostra a letra A de huma, e outra parte, e Fig.49Est.23 fica este corredor encostado ao terrapleno com porta para o dito corpo da guarda, para por ella se poder vir a combater o inimigo pellas seteyras que ficão no comprimento do dito corredor, que será de dez athe doze pés [3,33m até 3,96m], com huma parede de dous pés $[0,66 \mathrm{~m}]$ de groço que o divide do corpo da guarda; o comprimento deste mostrão as letras EF que será de trinta athe quarenta pés $[9,9 \mathrm{~m}$ até $13,2 \mathrm{~m}]$ respectivamente á grandeza da praça como dissemos no principio, e a sua largura será de vinte athe vinte e quatro pés $[6,6 \mathrm{~m}$ até $7,92 \mathrm{~m}]$, no meyo da qual podem haver colunas que sustentem a abobeda ${ }^{146}$ de que deve ser cuberto; deve de ter sua porta para o tranzito de quatro pés $[1,32 \mathrm{~m}]$ de largo, e outo [oito ou 2,64m] de alto; alguns the fazem duas janellas aos lados da porta, não sey para que fim, podendo em lugar de cada janella ter duas seteyras de que se póde fazer fogo sobre o inimigo, e assim em lugar daquellas se farão estas.

As tays janellas com outra porta se the farão na cabeceyra que olha para a parte da praça, como se ve na figura notadas com as letras I e P; esta porta que basta seja do tamanho da outra, serve para por ella acodirem os soldados á defença do tranzito; dentro destes corpos de guarda se fazem humas escadas de largura de quatro pés $[1,32 \mathrm{~m}]$ que sobem ao alto do terrapleno, para por ellas mais

\footnotetext{
${ }^{146}$ Em geral estes espaços do corpo da guarda são cobertos com abóbadas de berço e assim não necessitam das tais colunas. Elas só teriam sentido se a cobertura fosse feita com abóbada de aresta dividindo o vão em dois módulos estruturais.
} 
promptamente acodirem os soldados á defença necessaria, ou a largar o rastrilho. Deve tambem haver nestes corpos de guarda suas tarimas [modernamente, tarimbas] para os soldados de noute poderem descançar, que de dia assistem no tranzito, e assim mais nos paizes frios suas chaminés para os soldados de noute se aquentarem, e ainda acrescenta o nosso Methodo Luzitanico que se the fação suas cantareyras, e almarios [armários], mas julgo estes por desnecessarios, porque os soldados entrão e sahem de guarda todos os dias, e não levão com sigo couza alguma que hajão de guardar.

Como estes corpos de guarda ficão encostados aos terraplenos, costumão receber muytas humidades destes em tempo de inverno as quais são cauza de muytas enfermidades que os soldados recebem ${ }^{147}$; para evitar estas se lhe faz hum

Est. 24 corredor como mostra na figura 50 a letra N; este corredor será so de huma parte, porque da outra que leva a escada que temos dito não necessita delle.

Costumão alguns auctores quando as praças são de mediana guarnição não fazer mais que hum corpo de guarda, mas neste cazo sempre he percizo [sic] que da outra parte opposta se lhe faça hum corredor de outo pés $[2,64 \mathrm{~m}]$ de largo para os soldados acodirem á defença que se faz pellas seteyras que olhão para o tranzito; eu porém sempre lhe fizera os dous corpos de guarda,

\footnotetext{
${ }^{47}$ Chamamos a atenção para o problema crônico das fortalezas sentido desde muito pelos especialistas da engenharia das fortificações. Os cômodos que se encontram adossados ao terrapleno, ou recoberto com uma camada de terra que amenizava o efeito das bombas, sofrem com as infiltrações que não podem ser contidas eficientemente, mesmos com as técnicas modernas de impermeabilização que só resolvem o problema parcialmente. Pelo desenho o que Vellozo está propondo é um contramuro, mesma técnica que empregamos atualmente, em certos casos, para controle de umidade, mas que já era conhecido desde Vitrúvio. No restauro da Fortaleza do Barbalho propusemos como solução definitiva afastar o terrapleno das paredes, já que os reparos de terra não têm atualmente a função de absorver o impacto dos pelouros e a explosão das granadas.
} 
porque sendome forçozo fazer o corredor sobredito, que leva as mesmas paredes, com so a mayor despeza da abobeda e parte da parede da cabeceyra que olha para a praça se consegue a obra, e por tão pouco não he de razão desprezar a melhor defença, e a melhor commodidade dos soldados.

Quando os tranzitos são direytos se lhes costuma pôr diante da porta interior outros corpos de guarda fortes, guarnecidos com sua estacada em roda, e esta com sua porta; este corpo de guarda se faz quando se teme algu'a rebelião, especialm ${ }^{\text {te }}$ em praças conquistadas de novo, e aponta o nosso Methodo Luzitanico o exemplo do que obrarão os Castelhanos quando tomarão Evora; mas quando as praças são de vassalos naturays se podem escuzar estes corpos de guarda.

Cap. $^{\circ} 18 .^{\circ}$

DAS CANHONEYRAS.

Supposto temos repetidas vezes fallado em canhoneyras e dito o fim porque se fazem, que he para a artelheria jogar mais cuberta, e menos risco do artilheyro, e dos mais que com elle trabalhão, com tudo não dissemos a sua forma, nem as suas medidas, o que faremos neste capitulo com toda a clareza.

Varios são os modos de que uzão diversos auctores, porque huns as fazem direytas, isto he, tão largas pella parte da praça, como pela parte da campanha, como mostra a letra A; outros mais Fig. ${ }^{a} 54$ Est.27 largas da parte da praça, e mais estreytas da parte da campanha, como se ve notada com a letra B; outros tão largas de huma como de outra parte, e estreytas no meyo, e destas ha tres formas, como 
mostrão as letras C, D, E; outros mais largas da parte da campanha, e mais estreytas da parte da praça, como mostra a letra F; outros em redentes como reprezenta a letra G; finalmente fazendo-as mais largas da parte da campanha, vão estreytando-as para dentro athe certa distancia, e dahi as tornão a alargar para dentro da praça athe a face interior de dentro do parapeyto, como mostra a letra $\mathrm{H}$, e este ultimo modo he seguido de Antonio de Ville, Pedro Sardi, o auctor anonimo do novo modo de fortificar á Franceza, do Abbade de Fay, e do nosso Methodo Luzitanico, porque em todos os outros modos achão muytos inconvenientes, e assim nós tambem seguiremos o mesmo desenho, que he de seis palmos Fig. ${ }^{a} 55$ Est. 27 [1,32m] na boca interior IM, tres na gola [0,66m] NP, e esta deve entrar outros tres palmos na groçura do parapeyto, como $Q R$, e na boca exterior XZ dez palmos [2,20m]; nesta forma ficão os merlões menos expostos as ruinas, e as ballas inimigas muytas vezes se desvião, e não fazem tanto danno; (merlão se chama toda aquella porção de parapeyto que fica entre huma e outra canhoneyra) adverte o Methodo Luzitanico, e com muyto acertado fundamento, que as pontas da golla $\mathrm{N}$, e $\mathrm{P}$, se fação redondas, porque ficão assim menos expostas a serem rompidas pellas ballas inimigas.

Adverte mais o mesmo auctor que as canhoneyras porque so hão de jogar pessas pequenas, como por exemplo sacres ${ }^{148}$, e falconetes ${ }^{149}$, não necessitão de tamanha golla como os canhões, e colobrinas, mas não asigna o quanto devem ter de menos, e so o deyxa ao discurso do Engenheyro director da obra, sem embargo

\footnotetext{
${ }^{148}$ Os sacres ou sagres são pequenas peças de artilharia, equivalentes ao 1/4 de colubrina, que lançavam balas de cerca de 5 arráteis ou $2,29 \mathrm{~kg}$.

${ }^{149}$ Falconetes são peças ligeiramente menores que os sacres. Lançam balas de 1 a 4 libras (equivale ao arrátel) ou seja de $459 \mathrm{~g}$ a $1,836 \mathrm{~kg}$.
} 
do que lhe asignamos dous palmos athe dous e meyo [0,44m até $0,55 \mathrm{~m}]$, conforme for a groçura da pessa, e como estas sempre são mais curtas tambem faremos o comprimento da golla QR mais curto, dandolhe os mesmos dous palmos ou dous e meyo, para que a joya da pessa saya fóra della.

As canhoneyras não se costumão revestir de parede de pedra e cal, ou de tejollo, por evitar os muytos estilhaços, que fazem, os quais matão mais gente que as mesmas ballas, mas com huma camiza de adobes, ou de taypa de pilão que leva cal e area ${ }^{150}$, ou saybro, como sabem os artifices que as costumão fabricar.

Outros querem que sejão revestidas de taboões prezos, e seguros com traveças, e estacas pella parte interior, como diz Bonajuto Lorini, mas são muyto sugeytas a se queymarem com o fogo da mesma artelheria que por ellas labora. Pfeffinger quer que o revestimento das canhoneyras seja feyto de varas de salgueyro, enlaçadas e tecidas hu'as com outras, prezas em estacas, que se fazem firmes sobre o parapeyto; sendo que este modo se queyra executar, não falta neste paiz (em que escrevemos) materia apta para o intento, no $\operatorname{sip} \hat{0}^{151}$.

Temos dito athe aqui a forma em que se fazem as canhoneyras, e com que medidas, resta dizermos em que altura devem principiar, a qual deve ser de quatro athe cinco palmos [0,88m até $1,10 \mathrm{~m}]$ o mais, respeytando a altura das carretas; a distancia de hu'a a outra canhoneyra póde ser (segundo as medidas

\footnotetext{
${ }^{150}$ É o sistema construtivo empregado nas Fortalezas de S. Pedro e do Barbalho, sendo que nesta última foi ainda acrescido o pó de tijolo para aumentar a resistência.

${ }^{151}$ Não obstante o autor propor, em muitos casos, soluções que seriam mais adequadas para a Europa, donde era originário, adquiriu uma experiência de Brasil que o tornou apto a recomendar, com muita propriedade, os materiais locais, como o cipó. Em outra passagem do texto recomenda o bagaço da cana para fazer a faxina dos terraplenos.
} 
que traz o Methodo Luzitanico) de doze, quinze, athe vinte pés [3,96m, 4,95m até $6,6 \mathrm{~m}]$ ou ainda mais, conforme o mayor, ou menor numero dellas que se quizerem abrir no parapeyto; mas esta distancia que o dito auctor toma para a parte exterior do merlão, tomaremos nós para a parte interior da praça, sendo o menor termo os doze pés [3,96m] que dissemos em razão de ficar entre pessa e pessa capacidade não só para o seu manejo, mas para haver banqueta sufficiente para os soldados poderem sobir ao parapeyto a dispararem as armas sobre o inimigo.

Sem embargo de que o que temos dito athe aqui parece que bastava para se saberem deligniar as canhoneyras, poys temos asignadas as suas medidas, com tudo para os menos inteligentes póde não bastar, e assim he forçozo acrescentar o seguinte.[:] Assentado o numero de canhoneyras que se pertendem [pretendem] abrir na face de hum baluarte, no flanco, ou na cortina, levantado o parapeyto naquella altura que temos dito de quatro ou cinco palmos $[0,88 \mathrm{~m}$ ou $1,10 \mathrm{~m}]$ o mais, se asignarão os pontos do meyo de cada huma das ditas canhoneyras, como por Fig. ${ }^{a} 55$ Est.27 exemplo o ponto $Q$, do qual sobre a linha interior do parapeyto EL se levante a perpendicular QV; para huma e outra parte do ponto Q se tomem tres palmos [0,66m], a saber QM, e QI; do mesmo ponto $Q$ na linha $Q V$, se tomem outros tres palmos $[0,66 \mathrm{~m}]$ athe o ponto R; deste dito ponto $\mathrm{R}$ se tomem para huma e outra parte as distancias RN, RP cada huma de palmo e meyo [0,33m], de sorte que tirandose a linha PN seja esta de tres palmos $[0,66 \mathrm{~m}]$, e parallela com a linha interior do parapeyto EL: do ponto $\mathrm{V}$ na linha exterior do mesmo parapeyto se tomem cinco palmos $[1,10 \mathrm{~m}]$ para cada parte, e se signalem os pontos X, e Z, o que assim feyto tirem-se as linhas IN, NZ, MP, PX e ficará descripta, a canhoneyra, 
e assim se obrará nas mais, excepo [excepto] se se lhe quizer fazer a golla PN mais estreyta, para as pessas de menor calibre como ja dissemos.

Para as canhoneyras que se fazem nos flancos curvos, ou sejão altos ou bayxos, se não levanta a perpendicular que dissemos do meyo da canhoneyra, mas desse tal ponto se tira hu'a linha parallela ao revez do orelhão, ou espalda, e no mais se obra como fica dito, ou tambem como ensina o Engenheyro Portuguez no $\mathrm{Cap}^{\circ} 6$ do liv. $4^{\circ}$ pag. 194 onde se póde ver; mas o resgamento [rasgamento] de nove palmos [1,98m] que lhe dá, me parece pouco nos parapeytos groços; nos que não chegarem ao ultimo termo da groçura que admitimos se poderão fazer como elle ensina; e ainda dizemos mais, que nos parapeytos que forem mais delgados se não devem dar tamanho resgamento [rasgamento] á boca exterior das canhoneyras, por não ficar o merlão muyto fraco, e assim me parece que nos parapeytos de vinte e hum pé de groço $[6,93 \mathrm{~m}]$ que admitimos por ultimo termo mayor se the dem os ditos dez palmos [2,20m] de boca, e os mesmos se dem tambem nos parapeytos de vinte athe dezasete pés [6,6m até $5,61 \mathrm{~m}$ ] excluzive, e nos de dezasete athe treze [5,61 até 4,29m] excluzive, se dem nove palmos $[1,98 \mathrm{~m}]$, e nos de treze athe nove pés $[4,29 \mathrm{~m}$ até $2,97 \mathrm{~m}$ ] ultimo termo menor que admitimos se lhe dem outo palmos $[1,76 \mathrm{~m}]$ somente, porque desta sorte sempre descobrirão os mesmos pontos da campanha; sendo o parapeyto mais estreyto se lhe póde tambem diminuir a boca interior fazendo-a so de cinco palmos [1.10m], mas menos nada, em razão da pessa de artelheria poder enconteyrar-se par hu'a ou outra parte conforme for necessario. 


\section{$\operatorname{Cap}^{0} 19 .^{\circ}$ \\ DOS LEYTOS PARA LABORAR A \\ ARTELHERIA}

\section{Os leytos (a que muytos chamão explanadas) ${ }^{152}$ para} laborar a artelheria, são percizamente [sic] necessarios, e se fazem de bom lagedo rijo, e apicoado de picão groço na forma seguinte.[:]

No terrapleno que fica debayxo da cantoneyra se cavão cinco palmos e meyo athe seis [1,21m até $1,32 \mathrm{~m}$ ] de terra, com outo pés $[2,64 \mathrm{~m}]$ de largo junto ao parapeyto, vinte e cinco athe vinte e sete $[8,25 \mathrm{~m}$ até $8,91 \mathrm{~m}]$ de comprido, e quinze athe dezaseis [4,95m 5,28m] de largo no principio; isto assim feyto se the assenta huma grade de madeyra duravel, que tenha hum palmo em quadro de groço [22x $22 \mathrm{~cm}]$, ou ao menos meyo pé [0,165m]; em falta da grade se póde estaquear com estacas de seis [1,32m] athe outo palmos $[1,76 \mathrm{~m}]$ de comprido, o mais miudas que o terrapleno possa admitir ${ }^{153}$; sobre estas se fará hum massame de pedra e cal de tres palmos athe tres e meyo $[0,66 \mathrm{~m}$ até $0,77 \mathrm{~m}]$ de alto, sobre o qual se assentarão as lages de boa qualidade de pedra (como dissemos ao principio) as mayores que possa ser, bem ensopadas em cal com palmo e meyo [0,33m ou um pé] de groço, ou ao menos hum palmo; as juntas serão bem unidas, e tomadas com

\footnotetext{
${ }^{152}$ Estes leitos seriam as plataformas sobre as quais a peça de artilharia opera. Chamá-los de esplanadas não seria conveniente porque poderia fazer confusão com a esplanada, (arcém ou glacis) que está depois da estrada coberta. Sobre estes leitos, ver a interpretação do detalhe construtivo que fizemos no nosso texto sobre As fortificações portuguesas de Salvador p. 163. Desenhos esclarecedores deste detalhe são também encontrados no (Le Triomphe de la Méthode) Traitédel'attaque dès places de Monsier de Vauban Ingenieur du Roi, publicação apresentada por Nicolas Faucherre e Philippe Prost. p. 18 e 19.

${ }^{153}$ Ensinamento claramente vitruviano sobre o qual tivemos oprotunidade de refletir em texto apresentado ao First International Congress on Construction History.
} 
cal de betume ${ }^{154}$ : o nosso Methodo Luzitanico seguindo a Sardi, e a Vilhegas quer que as lages tenhão pé e meyo [0,49m], ou pé e hum quarto $[0,41 \mathrm{~m}]$ de groço, mas isto he difficultozo de achar, e por isso me accommodo com ellas de palmo e meyo [0,33m], e ainda de hum palmo $[0,22 \mathrm{~m}]$, mas nada menos, se puderem ter mais, serão melhores, com tanto que sejão de cinco palmos [1,10m] de comprido para sima, dous e meyo [0,55m] de largo, e as fiadas correrão todas por igual.

Alguns auctores fazem estes leytos mais altos da parte interior, e mais bayxos junto ao parapeyto, com o fundamento de que assim recua menos a artelheria, e mais depreça se chega ao parapeyto.

Outros pelo contrario os fazem mais altos junto ao parapeyto, e mais bayxos na parte interior, dizendo que assim fica a artelheria mais cuberta depoys de recuar, mas este fundamento de aereo, e assim se não deve admitir, porque rezultão delle dous gravissimos inconvenientes, o primeyro que recua muyto a artelheria por achar o pavimento em declive; o segundo que custa muyto, e necessita de muyta gente para se chegar outra vez ao parapeyto por lhe ser forçozo subir.

Os melhores são os que se fazem a livel tão altos em hu'a como em outra parte, e nesta forma os faremos nós tambem; e so em cazo de necessidade os faremos mais altos hum pé $[0,33 \mathrm{~m}]$ na parte interior, porque sendo mais forcejão muyto as carretas, o que he cauza de se espedaçarem. A necessidade que asima

\footnotetext{
${ }^{154}$ Esta cal de betume é, possivelmente, originária da extinção da cal viva com óleo o que forma uma espécie de massa impermeável. Pode tratar-se, também, do famoso "tetim" ou "titin" referido em um texto de Frias da Mesquita comentado em nosso texto sobre As fortificações Portuguesas de Salvador, p. 151.
} 
dizemos so se dará quando os terraplenos forem mais estreytos, de sorte que não possão as pessas ter tanto recuo, porque se não póde dar outra.

Póde succeder que se não ache lagedo capaz, neste cazo se farão de madeyra na seguinte forma.[:] Tomem-se quatro traves de boa e duravel madeyra, de hum palmo [0,22m] de groço em quadro, e do comprimento que se quizer dar ao leyto, as quais se assentarão sobre estacas cravadas no terrapleno, da mesma qualidade de madeyra de sete ou outo palmos $[1,54 \mathrm{~m}$ ou $1,76 \mathrm{~m}]$ de comprido, e tambem hum $[0,22 \mathrm{~m}]$ de groço sobre cujas cabeças se pregarão as ditas traves com pregos fortes e compridos; o vão entre trave e trave se encherá de terra bem batida, e anivelada, e por sima de tudo isto se assentarão pranxões de madeyra escolhida, de groçura de meyo palmo $[0,11 \mathrm{~m}]$, não falta quem os queyra mais groços, mas isto he o que basta, e serão pregados nas traves de sorte que as cabeças dos pregos fiquem embebidos na madeyra.

O Methodo Luzitanico parte $1^{\text {a }}$ Secção $1^{\text {a }}$ Cap $^{\circ} 32$. $\S 3^{\circ}$ pag 134 tratando destas explanadas de madeyra, alem de fazer os barrotes mais delgados, os assenta atraveçados, isto he parallelos ao parapeyto, e sobre elles poem os pranxões ao comprido, mas com licença de hum tão grande engenho me parece não ser conveniente esta forma, porque sucedendo correr hu'a roda da carreta por sima da junta que fazem dous pranxões facilmente os descomporá, o que não succede correndo por sima delles sendo postos atraveçados.

Advirtase que as traves que ficão da parte de fora devem ser postas bem a face, de sorte q' só as pontas dos pranxões assentem sobre ellas. A terra do terrapleno entre os sobreditos leytos deve ficar no seu mesmo livel, nem mais alta, nem mais bayxa. 
Alguns fazem tanto estes leytos de madeyra, como os de pedra em fórma de parallelogramo rectangulo, tão largos adiante, como atraz; não reprovamos esta fórma, mas dizemos que quem não quizer poupar madeyra ou lagedo os faça como the parecem melhores.

O Engenheyro Portuguez diz que sem embargo de que a mayor parte dos auctores fação os leytos de lagedo, o seu parecer he de que se fação de madeyra, a qual póde estar cortada; e aparelhada recolhida em armazens, para na occazião se poderem servir delles, porque os de lagedo estão sugeytos ás bombas que os desfaz em estilhaços com grande danno dos defensores mas como os de madeyra (supposto não fação estilhaços) estejão sugeytos a serem espedaçados com as mesmas bombas, poys não poderão rezistir ao grande impulso, não os devemos preferir aos de lagedo, so donde o não houver como ja se disse.

Bonajuto Lorini quer que se possão fazer estes leytos sobre quatro rodas que se possão mover de hu'a para outra parte; o Methodo Luzitanico diz que lhe parece terem suas conveniencias, mas que tambem the acha seus incommodos, e eu julgo serem empraticaveys pella difficuldade de mover semelhantes maquinas, ainda que andem sobre rodas.

$$
\operatorname{Cap}^{\circ} 20^{\circ}
$$

DAS CIDADÉLAS.

Cidadellas, ou citadellas como alguns the chamão, são huns fortes de quatro, cinco, athe seis baluartes, que se incorporão no recinto da praça fortificada, parte dos baluartes 
da qual fica olhando para a campanha, e parte para dentro da praça; Antonio de Ville no seu Governador de praças aponta varias razões porque se fazem sendo o principal para sugeytar e ter em obediencia os moradores quando são sediciozos, e pouco obedientes, ou quando são povos de novo conquistados, que sempre aspirão a antiga liberdade, e tornar ao dominio do seu Principe natural, e as cidadellas os fazem conter obedientes; de hu'a e outra couza ha muytos exemplos que escuzamos repetir.

Fazem-se tambem quando em algum dos lados da praça ha sitio sufficiente para mayor defença desta, e para refugio da guarnição no cazo de ser a praça entrada, porque ou da cidadella se expelle outra vez ao inimigo ou não tendo outro remedio se capitula, tendose a principio recolhido a ella todo o preciozo dos moradores para o livrar do saque.

Comummente uzão os auctores de eleger os sitios mais elevados que ha no recinto da praça para nelles formarem as ditas cidadellas, e não ha duvida que estes tays são os melhores e mais proprios para o intento, sem embargo de que póde haver occazião ou motivo de as fabricar em sitio plano, isto succede infalivelm ${ }^{\text {te }}$ quando as praças fortificadas são em campanha raza, ou quando por dentro dellas passa algum rio em que he necessario fundar a cidadella na margem delle, o que se fará sempre da parte da corrente, mas de sorte que não fique dominada de algum alto donde possa ser batida ${ }^{155}$.

Dissemos no principio deste capitulo que as cidadellas são huns fortes de quatro, cinco, athe seis baluartes, dos quais dous sempre olham para dentro da praça, e os mais para a campanha; as

\footnotetext{
${ }^{155}$ Este alto seria um padrasto cujo significado já foi explicitado anteriormente.
} 
cidadellas de quatro baluartes são rarissimas, ainda que no nosso reyno ha algumas; de seys baluartes ha poucas, e de sete ainda menos, porque tem huns inconvenientes; de cinco ha muytas por toda a Europa ${ }^{156}$, e são hoje as mais uzadas por terem bastante capacidade para dentro nellas se fabricarem quarteys para o presidio, armazens para munições, e petrechos de guerra, e tambem para as de boca, e assim seguiremos esta ordem de as fazer pentagonicas $^{157}$.

Muytas vezes succede haver dentro do recinto da praça algum sitio $\mathrm{m}^{\text {to }}$ elevado no qual he força fabricar a cidadella, mas neste cazo não lhe fica proprio o nome, mas sim o de castello, mas estes tem hum grande inconveniente como aponta o Methodo Luzitanico $\mathrm{Cap}^{\circ} 12^{\circ}$ pag. 327 que he que no cazo de rendida a praça fica exposto a se entregar tambem por não poder ser socorrido, sem embargo disso muytos se tem defendido valerozamente [valorosamente].

O nosso Engenheyro Portuguez Cap. ${ }^{\circ} 12$ pag. 152 repara com bem judicioza razão em hum grande erro em que tem cahido todos os auctores, e diz que he erro bem patente, porque em hu'a praça grande cujos flancos são bem grandes, e as tenalhas fortes e robustas fazem as da cidadellas que olhão para a campanha pequenas, e com

${ }^{156}$ As cidadelas pentagonais com baluartes em ponta de lança foram propostas desde o Renascimento e a de cinco pontas são aquelas apontadas mais detalhadamente por Pietro Cataneo em I quattro primi libri di Architettura.p. 12 e 13.

${ }^{157}$ Desde os primórdios da formação da Cidade do Salvador que, na administração de Diogo Botelho, era reclamada a feitura de uma cidadela, influência possível dos conselhos de Frias da Mesquita. Este chegou, inclusive, a fazer um projeto de cidadela para Salvador, que pode ou não ter sido executado. No Século XVIII, o projeto de fortificação desta cidade feito pelo Brigadeiro Massé, com a parceria de Mestre de Campo Miguel Pereira e o Capitão Gaspar de Abreu, previa a construção de uma cidadela exatamente pentagonal, como recomendava Vellozo, que deveria ser edificada no local da atual abadia de São Bento, mas que foi, finalmente, deslocada na proposta para a Mouraria, em vista da resistência dos monges de arredar o pé de onde estavam. 
flancos limitados, e que havendo esta praça ser atacada, mais facilmente o poderá ser pella cidadella, por ter esta menos força, e que entrada ella fica logo perdida a praça, e que assim para obviar este tam grande inconveniente he percizo [sic] fazer as tenalhas que olhão para a campanha tanto ou ainda mais fortes que as mesmas da praça principal, mas isto se entende quando o sitio em que se fes a cidadella póde ser atacado, porque ha sitios tays, e tão fortes por natureza, que qualquer leve fortificação nelles he inexpugnavel: a tenalha que olha para dentro da praça de menos força necessita.

$\mathrm{Na}$ figura 56 se ve desenhada hu'a cidadella pentagonica, cuja proporção de suas partes he a mesma que as da praça principal, e assim he escuzado o repetillas, e so sera percizo [sic] advertir que dos angulos flanqueados da praça principal A e $\mathrm{B}^{158}$ se tirão dous ramais que venhão a entestar com as cortinas da cidadella, tomando desta toda a defença possivel, ficando por este modo sendo so meyos baluartes os da praça principal como se ve na sobredita figura 56 .

Muytas vezes não póde ser a cidadella regular, ainda que a praça em si o seja, porque tal he o terreno que della ha para fora que não admite regularidade alguma, o que se tem visto em muytas praças da Europa, especialmente quando as cidadellas são fundadas em sitios altos que nos planos he mais facil o chegar-se á regularidade.

Ha tambem alguns sitios eminentes fóra do recinto da praça que he necessario ganhar, porque o inimigo se não senhore-e [sic] delles e ponha bateria contra a praça com que lhe faça notavel danno; nestes tays (sendo capazes) he percizo [sic] fazerem-se cidadellas; muytos auctores the não querem neste cazo chamar assim, se não fortes, como por exemplo o de Sam Christovão na

\footnotetext{
${ }^{158}$ Estas letras (A e B) não estão indicadas na Fig. 56.
} 
praça de Badajos; o de Santa Luzia na nossa de Elvas, e outros muytos em diversas praças, assim nossas, como na mais Europa; estes fortes costumão ter huns caminhos cubertos para dentro da praça a que chamão linhas de commonicação [sic], por onde são socorridos na occazião, e no cazo de serem rendidos por elles se retira a guarnição; algumas destas linhas ou caminhos costumão ser por bayxo do cham [chão], e são os mais seguros, como o da praça de Elvas para o referido forte de Santa Luzia.

Todas as cidadellas devem ter duas portas (alguma ha que tem tres) a primeyra para dentro da praça por onde se lhe mete a guarnição, a segunda para a campanha, para por ella poder ser socorrida no cazo que os payzanos intentem ganhala por cauza da rebelião.

Os fortes asima ditos nunca devem ter mais do que huma [cidadela], e essa fronteyra á praça, porque para a campanha não tem necessidade della.

Os fossos das cidadellas se comonicão com o da praça principal, como tudo mostra a referida figura, e o seu desenho, como tambem o das muralhas he o mesmo que temos ensinado para as praças respeytando ao comprimento do lado da figura.

$$
\operatorname{Cap}^{\circ} 21 .^{\circ}
$$

DAS OBRAS EXTERIORES EM GERAL

\section{Obras exteriores são todas aquellas que se fazem para cobrir as partes da praça principal, e consequentemente para lhe aumentar a defença; constão de revelins, hornaveques, tenalhas, coroas, ou obras coroadas, obras cornas, meyas luas, caudas de andorinha, barrtes [barretes] de clerigo, e contraguardas.}


Revelim he hu'a que consta de duas faces que formão angulo para a parte da campanha assentada sobre o angulo da contraescarpa do fosso defronte da cortina, tomando sua defença das faces dos Est. 29 baluartes oppostos como se reprezenta na figura 57 varios são os revelins de que tratão os auctores como diremos adiante.

Hornaveques são hu'as obras avaçadas para a campanha com dous lados rectos, e no terceyro dous meyos baluartes oppostos Est. 29 ao inimigo, como se ve na figura 58; ha tres castas delles, a saber os que tem os dous lados ou ramais mais abertos da parte da campanha, e mais fechados da parte da praça se chamão convergentes; os que pello contrario os tem mais abertos da parte da praça, e mais fechados da parte da campanha, se chamão devergentes [sic]; os terceyros são os que tem os ramais parallelos.

Tenalhas são humas obras exteriores que diferem dos hornaveques em que em lugar dos dous meyos baluartes tem so hum angulo reintrante, e então quando nesta forma se obrão se chamão simples, e quando tem dous angulos internos reintrantes, e hum externo saliente se chamão dobres, o que tudo reprezentão Est. 30 as figuras 59, e 60, adiante diremos a sua deligniação.

Coroas, ou obras coroadas se chamão aquellas que tendo dous meyos baluartes nos lados, tem tambem hum ou mais baluartes inteyros

Est. 30 no meyo, como se mostra na figura 61, a qual he assim chamada, porque coroa e cerca em roda parte da fortificação principal da praça.

Obras cornas, não tem differença dos hornaveques, e por isso escuzamos dizer a sua definição ${ }^{159}$.

\footnotetext{
${ }^{159}$ Da maneira que foi colocado parece que são dois elementos de defesa embora semelhantes. Na realidade seria menos complicado dizer no mesmo parágrafo: Hornaveque ou Obra Corna, porque o termo hornaveque tem origem holandesa de horn, ou seja, chifre ou corno.
} 
Meyas Luas differem muy pouco dos revelins; fabricão-se defronte dos angulos flanqueados, e o lado que fica interiormente olhando para elles se faz circular em forma de huma porção de Lua, e isto he porque são fabricadas sobre o redondo da contraescarpa, como se ve na figura 62.

Caudas de andorinha he huma obra que differe somente da tenalha simples em que os ramais desta são parallelos entre si, e os da cauda de andorinha são convergentes, isto he, mais fechados da parte da praça como a figura 63 .

Barretes de clerigo são semelhantes as tenalhas dobres excepto, que os seus ramays são convergentes para a parte da pra- Est.31 ça, como se mostra na figura 64 .

Ultimamente contraguardas, he o mesmo que meyas Luas, segundo os auctores modernos, que os antigos não tratarão dellas, por não serem ainda conhecidas.

Regras gerays que se devem observar nas obras exteriores.

Primeyra, que fiquem dentro do tiro de mosquete da praça $\mathbf{p}^{\mathbf{a}}$ se defenderem com mais ventagem $[\mathrm{sic}]^{160}$.

Segunda, que a sua altura seja so a que baste para se varrer o campo ao inimigo.

Terceyra, que todas sejão abertas pella parte da praça, para que no cazo de serem entradas pello inimigo fique este descuberto, e exposto aos tiros da praça.

\footnotetext{
${ }^{160}$ É um princípio que prevalece até os dias atuais feitas as devidas adaptações, pois recomenda-se que os obstáculos só são efetivos se tiverem a cobertura das armas dos defensores.
} 
Quarta, que havendo duas obras exteriores huma mais avançada a campanha que a outra fique a mais proxima da praça mais levantada que a mais afastada, para poder della ser batida, no cazo que o inimigo a ganhe.

Deligniação dos revelins simples e sua situação.

Os revelins sempre se fazem defronte das cortinas especialmente nas que tem portas para as cobrir; a sua deligniação he na seguinte forma.[:]

Fig. ${ }^{a}$ 6Est. 31 Do angulo da contraescarpa A defronte do meyo da cortina se levante hu'a perpendicular indefinita para a parte da campanha nella se tome a linha $\mathrm{AB}$ igual a ametade da mesma cortina; do ponto $\mathrm{B}$ se tirem as linhas $\mathrm{BC}$, e $\mathrm{BD}$, em direytura dos angulos da espalda, as quais linhas se terminarão na contraescarpa e ficará formado o revelim.

\section{Por outro modo}

Fig. ${ }^{a}$ 65 Est. 32 Do ponto medio da cortina S se levante hu'a perpendicular indefinita para a parte da campanha; desta alem do fosso se corte para a capital a linha $\mathrm{EH}$ igual aos tres quartos, dous terços, ou ametade da face VZ; do ponto E se lancem linhas em dereytura dos angulos flanqueantes $\mathrm{Y}$, e X, athe toparem com a contraescarpa, e ficará desenhado o revelim, o qual por este modo cobre toda a cortina, e ficão as suas faces EF, e EG, defendidas das faces dos baluartes, e tambem tomão alguma defença dos flancos. 
Por outro modo

Conforme traz o Engenheyro Portuguez.

Toma este auctor sete braças $[15,4 \mathrm{~m}]$ nas faces dos baluar- Fig. ${ }^{a} 66$ Est. 32 tes, principiando dos angulos da espalda, como por exemplo de $\mathrm{A}$ athe $\mathrm{B}$; tira depoys a linha $\mathrm{BB}$, a qual divide em outo partes iguais, e com a distancia de sete descreve dos ditos pontos B, e B, para a parte da campanha dous arcos que se cruzem no ponto $\mathrm{N}$, do qual tira as linhas NX, e NZ, em direytura dos pontos BB, e fica deligniado hum grande revelim, dentro do qual faz outro revelim mais pequeno, que desenha na seguinte forma.[:]

Toma na cortina bayxa nove braças $[19,8 \mathrm{~m}]$ de huma e outra parte, como de D para E, e com a distancia EE (que he o resto da cortina) descreve para dentro do revelim grande dos mesmos pontos EE, como de centros dous arcos que se cruzarão no ponto $\mathrm{F}$, então tirando deste dito ponto $\mathrm{F}$ as linhas $\mathrm{FG}$, e FH, em direytura dos ditos pontos EE, ficará deligniado o pequeno revelim.

Adverte o dito auctor que nos poligonos da pequena fortificação se tomem somente quatro braças e meya [9,9m] sobre a cortina bayxa, para dahi tirar as faces do pequeno revelim.

\section{Por outro modo}

Segundo o nosso Methodo Luzitanico.

Do ponto V meyo da cortina se levante huma perpendicular Fig. ${ }^{a} 67$ Est.3[3] indefinita, como por exemplo VCO, a qual cortara sempre pello meyo o angulo da contraescarpa C; nella se tome a porção CO igual aos tres quartos da sobreface $\mathrm{AL}$; dos pontos $\mathrm{S}$ e $\mathrm{T}$, extremos da cortina se tomem nella as porções $\mathrm{SN}$, e TM, iguais a sexta parte da capital $\mathrm{CO}$, e do ponto $\mathrm{O}$ se tirem as linhas $\mathrm{OM}, \mathrm{ON}$, 
[Fig. ${ }^{a}$ 68Est.33] as quais determinarão na contraescarpa as faces do revelim O5, e O8, isto he para o quadrado, mas para o pentagono se tirarão as faces OX, OV em direytura dos pontos $\mathrm{M}$, e N, meyo dos flancos rectos, e no mais se obrara do mesmo modo.

Fig. 68 Est. 33

Para o exagono, heptagono, e todas as mais figuras dahi para sima, se tomem para capital os quatro quintos da sobreface AL, e do dito ponto $\mathrm{O}$ se tirem as linhas OR OY, em direytura dos angulos da espalda dos baluartes as quais cortarão a contraescarpa nos pontos $\mathrm{E}, \mathrm{F}^{161}$, e formarão as faces do revelim.

\section{Por outro modo} Segundo Martias ${ }^{162}$, a quem segue Melder ${ }^{163}$.

$\mathrm{Na}$ perpendicular indefinita que se levanta do angulo da contraescarpa toma deste auctor trinta toezas, ou 180 pés $[59,4 \mathrm{~m}]$ para capital do revelim como $\mathrm{AB}$; do extremo $\mathrm{B}$ tira as faces $\mathrm{BE}$, $\mathrm{BF}$, em direytura dos angulos da espalda $\mathrm{D}$, e C, mas esta capital he pequena, e dahi se segue ficar o angulo flanqueado do revelim mayor que recto o que se não admite, nem tambem menor de sessenta graos.

Outros differentes modos puderamos aqui trazer, mas estes nos pareceu serem os que bastão para os curiozos, quem ainda se não contentar com estes consulte a Pfeffinger liv. $3^{\circ} \mathrm{Cap}^{\circ} 2, \S 1^{\circ}$ pag. 131 onde achará outros diversos, mas seja por este ou por aquelle modo, nunca a differença he grande.

\footnotetext{
${ }^{161}$ Os pontos E e F não estão indicados no desenho.

${ }^{162}$ Não nos foi possível até o momento identificar o tratadista a quem Vellozo fazia referência. Seria Martz?

${ }^{163}$ Gerard Melder foi engenheiro militar do Século XVII, de possível origem alemã, mas, segundo Marini, seguidor dos teóricos da arquitetura holandesa e de princípios do Conde de Pagan.
} 
No que toca ao seu perfil, tambem são diversos conforme o capricho de cada hum dos auctores que temos apontado; o nosso Methodo Luzitanico lhe dá para a baze do reparo AB Fig. ${ }^{a}$.70 Est.34 de 24 athe 44 pés [7,92 até 14,52m], conforme for a grandeza do revelim.

de talud exterior do reparo $\mathrm{DB}$, de 2 athe 6 pés $[0,66 \mathrm{~m}$ até $1,98 \mathrm{~m}]$.

de talud interior do reparo $\mathrm{CA}$, de 4 athe 8 pés $1,32 \mathrm{~m}$ até $2,64 \mathrm{~m}]$.

de altura do reparo FD ou EC, de 4 athe 8 pés $[1,32 \mathrm{~m}$ até $2,64 \mathrm{~m}]$.

de largura superior do reparo EF, de 18 athe 30 pés $[5,94 \mathrm{~m}$ até $9,9 \mathrm{~m}]$.

de largura inferior $\mathrm{AB}$, de 24 athe 44 pés [7,92m até $14,52 \mathrm{~m}]$. de baze do parapeyto do reparo GF, de 8 pes athe 16 e $3 / 4$ [2,64m até $5,52 \mathrm{~m}]$.

de talud exterior do parapeyto $\mathrm{HF}$, de 2 pes athe 3 e $3 / 4$ [0,66 até $1,23 \mathrm{~m}]$.

de talud interior do parapeyto IG, sempre 1 pé [o,33m].

de altura exterior do parapeyto MK, de 4 athe 5 pés [ 1,32 até $1,65 \mathrm{~m}]$.

de altura interior do parapeyto IL, 6 pés $[1,98 \mathrm{~m}=9$ palmos ou 1 toeza].

de largura superior do parapeyto KP, de 5 athe 12 pés $[1,65 \mathrm{~m}$ et[e $3,96 \mathrm{~m}]$.

de largura da banqueta GNMO, 3 pés [0,99m].

de altura da banqueta $\mathrm{MO}, 1$ pé e $1 / 2[0,49 \mathrm{~m}]$.

de largura do terrapleno OE, de 7 athe 13 pés [2,31 até $4,29 \mathrm{~m}$ ]. de lezira ou berma BQ de 3 athe 6 pés [0,99 até 1,98m]. 
de largura superior do fosso QR, de 30 athe 54 pés $[9,9 \mathrm{~m}$ até $17,82 \mathrm{~m}]$.

de talud interior e exterior do fosso QV, e XR, de 3 athe quatro pés $[0,99 \mathrm{~m}$ até $1,32 \mathrm{~m}]$, e não seja nunca mayor.

de profundidade do fosso XT, ou VS, de 6 athe 8 pés $[1,98 \mathrm{~m}$ até $2,64 \mathrm{~m}]$.

de que rezulta a largura inferior do fosso ST, de 24 athe 46 pés $[7,92$ até $15,18 \mathrm{~m}]$.

Advirtase que as menores medidas deste perfil são so para aquelles revelins, que se fazem de repente, a que chamão temporarios, por algum insidente que os obriga a fazer apreçadamente; as mais medidas se tomarão regularmente conforme for a grandeza do revelim, ou outra qualquer obra exterior porque serve para todas.

Pfeffinger pagina 183 tras o perfil seguinte tambem para todas as obras exteriores.[:]

$A$ baze do reparo $A B$, de 48 athe 60 pés [15,36m até $19,20 \mathrm{~m}]$. O talud interior do reparo AC, de 14 pés $[4,48 \mathrm{~m}]$. A baze da escarpa exterior do reparo de 8 pés. DB [2,56m] A altura do reparo DF, de 14 pés [4,48m]. A baze do parapeyto GF, de 18 pés [5,76m]. A escarpa interior do parapeyto GI, 1 pe e $1 / 2[0,48 \mathrm{~m}]$. A escarpa exterior do parapeyto $\mathrm{HF}$, de 4 pés [1,28m]. Largura da banqueta superior de 3 pes. MN [0,96m]. Largura inferior da banqueta GO de 3 pes e $1 / 2$ [1,12m]. Altura da banqueta GN 1 pe e $1 / 2[0,48 \mathrm{~m}]$. Altura interior do parapeyto IL 6 pés $[1,92 \mathrm{~m}]$. 
Altura exterior HK 3 pes e 1/2 [1,12m].

A berma BQ de 6 pés $[1,92 \mathrm{~m}]$.

A largura superior do fosso 72 e dous [72 pés? 23,04m] QR.

A escarpa interior do fosso QS de 7 athe 14 pés [2,24 até $4,48 \mathrm{~m}]$.

A escarpa exterior TR o mesmo.

A profundidade do fosso TX, ou SV de 14 pés $[4,48 \mathrm{~m}]$.

Advirtase que este auctor tras estas medidas por toezas, que cada hu'a são seis pés regios de França, mais pequenos que os pés Portuguezes, e desses he que fallamos ${ }^{164}$.

Dos revelins reforçados com flancos.

Monsieur de Vauban depoys de desenhado o revelim sim- Fig. ${ }^{a} 71$ Est. 35 ples, para the fazer flancos toma sobre cada demigola cinco toezas, ou trinta pés regios como $\mathrm{BD}$, e CE, e levanta sobre os pontos $\mathrm{D}$, e E, perpendiculares a cortina, as quais cortarão as faces do revelim nos pontos F, e G, e estes determinarão os flancos DF, e EG.

Monsieur Ozanam faz estes flancos nos revelins muy pequenos, e dá a razão, que he por não descobrir muyto os flancos da praça principal, no que parece anda bem advertido.

O abbade de Fay, com o auctor do novo methodo de fortificar a Franceza lhe não deteminão comprimento certo a estes flancos, mas o deyxão á dispozição do Engenheyro director da obra.

\footnotetext{
${ }^{164}$ Em virtude desta observação entendemos que Pfeffinger tenha assinalado na sua relação de medidas os valores em toezas e Pés Régios da França, com valor de 0,32m, segundo a tabela de Serrão Pimentel, logo, mais pequenos que os pés Portuguezes como diz Vellozo. Entretanto, não está muito claro porque no manuscrito o nosso autor diz $e$ desses é que falamos. Seriam os pés portugueses de 0,33 ou o Pé Régio?
} 
Dos revelins em forma de tenalha.

Deligniado o revelim simples por qualquer dos modos que fica ensinado, se lhe produzem as suas faces para diante do seu fosso, e nellas se tomem trinta toezas, ou cento e outenta pés regios $[57,60 \mathrm{~m}]$, principiando da contraescarpa do seu fosso, como por Fig. ${ }^{a}$ 72 Est. 35 exemplo de A para B; tomem-se quinze toezas ou noventa pés $[28,80 \mathrm{~m}]^{165}$ do angulo C, que faz a contraescarpa do seu fosso com a do fosso da praça athe o ponto $\mathrm{D}$, do qual se tirem as linhas $\mathrm{BD}$, e ficarão descriptas as contraguardas que formão com o revelim a tenalha.

O seu fosso he sempre parallelo aos ramais DB, como tambem o he o fosso do revelim as suas faces. O Engenheyro Portuguez faz a mesma deligniação, excepto que toma na face produzida de A athe $B$ de 23 athe 27 braças [50,6m até 59,4m], e na contraescarpa CD toma so outo, ou nove braças [17,6m ou $19,8 \mathrm{~m}]$.

Alguns the acrescentão hum pequeno revelim entre as duas contraguardas que desenhão na forma seguinte.[:] Do angulo do Fig. ${ }^{a}$ 73Est. 36 fosso das contraguardas E se levante hu'a perpendicular de 120 pés regios $[38,4 \mathrm{~m}]$ como $\mathrm{EF}$; partam-se as faces das contraguardas pello meyo nos pontos $\mathrm{G}$ e $\mathrm{H}$; tirese do ponto $\mathrm{F}$ extremo da capital hu'a linha recta em direytura dos pontos $\mathrm{G}$ e $\mathrm{H}$, meyo das faces the topar com a contraescarpa, e formará as faces do pequeno revelim.

O seu fosso terá de 42 athe 48 pés de largo, e o demais he como nas contraguardas.

\footnotetext{
${ }^{165}$ Conversão em Pé Régio de 0,32m.
} 
Dos revelins em forma de hornaveques.

Deligniado primeyro o revelim pello terceyro modo que aqui Fig. $^{a} 74$ Est. 36 trazemos; pello ponto do seu angulo flanqueado lançaremos huma linha parallela a cortina da praça, na qual se tomem de hu'a e outra parte do dito angulo flanqueado duas porções cada hu'a igual a quarta parte da cortina da praça, como por exemplo AA; destes ditos pontos AA se levantem duas perpendiculares para a campanha cada hu'a de vinte braças, ou 200 palmos [44,0m], nas quais se signalarão os pontos CC em distancia de 36 palmos [7,92m] dos pontos AA; por estes ditos pontos $\mathrm{C}, \mathrm{C}$, e pellos extremos das perpendiculares $\mathrm{AB}$ se tirem as faces BD de 270 athe 315 palmos [59,4m até $69,3 \mathrm{~m}$ ]; os ramais DE se tirarão em direytura do ponto $\mathrm{G}$ na face do baluarte onde vem parar as faces do revelim produzidas; e os flancos se tirarão do ponto $\mathrm{B}$ athe encontrarem a contraescarpa do fosso do revelim no ponto A.

Querendose fazer hum revelim na frente desta tenalha se tomarão doze pés [3,96m] sobre as faces dos meyos baluartes des- Fig. ${ }^{a} 74$ Est. 36 de o angulo da espalda $\mathrm{B}$ athe $\mathrm{F}$, e com a distancia $\mathrm{FF}$ dos mesmos pontos $\mathrm{F}$ e $\mathrm{F}$ como de centros se descreverão dous arcos para a parte da campanha que se cruzem no ponto $\mathrm{H}$, e ficará descripto o revelim, cujo fosso he parallelo as suas faces, e em tudo igual ao do revelim principal, e meyos baluartes; defronte dos angulos flanqueados destes, e tambem do segundo revelim se the faz seu redondo como se tem ensinado nos fossos da praça principal.

Dos hornaveques simples.

Os hornaveques, ou obras cornas (que tudo he o mesmo como ja dissemos) se fabricão defronte das cortinas ou tambem do angulo flanqueado, porem são melhores quando cobrem a cortina, 
do q' quando cobrem o baluarte, especialmente tendo os lados parallelos, porque cobrindo os baluartes com lados parallelos, quazi não tem outra defença que da cortina, e esta não muyto eficaz, a respeyto da grande distancia, a que se acrescenta, que não póde deyxar de ficar assim a obra muyto estreyta, e assim sendo forçozo levantallos defronte dos baluartes será percizamente [sic] necessario que os seus ramais sejão convergentes, isto he que da parte da praça sejão mais estreytos, e vão alargando para a parte da campanha, por não encobrirem toda a face do baluarte, mas ficar descuberta alguma parte della para dahi poderem ser defendidos os seus ramais.

Se se fizerem defronte da cortina sempre os seus ramais serão parallelos, excepto quando no cazo desta ser muyto pequena nos obrigue a fazellos convergentes para the aumentar o lado exterior; devergentes [divergentes], que he mais largos da parte da praça e estreytos da parte da campanha rara ou nenhuma vez succede, a sua deligniação he a seguinte.[:]

Sobre o parapeyto da estrada encuberta se lancem duas linhas parallelas para a parte da campanha de sorte, que se forem produzidas para a parte da praça fiquem em direytura dos flancos

Fig. ${ }^{a} 75$ Est. 37 dos baluartes como por exemplo KF, IE; em cada huma dellas se tomem o mais athe setecentos e dez pés [234,3m]; tirese a linha FE, e sobre cada hum dos extremos della se faça hum angulo de 25 graos como FEG, EFH: hum destes por exemplo FEG se parta pello meyo com a recta EL a qual produzida se hira encontrar com a linha FH no ponto C; feyto isto de EG se corte ED igual com FC, e serão por tanto FC, ED as faces dos meyos baluartes. Dos pontos $\mathrm{D}$ e $\mathrm{C}$ se tirem as linhas $\mathrm{CB}$ e DA parallelas com os ramais FK e EI cada huma de $3 / 5$ da face FC, ou ED: ultimamente se tire a cortina $\mathrm{AB}$, e ficara deligniada a obra corna, ou hornaveque. 
Por outro modo, e com mayor facilidade.

Tirados os ramais KF e IE na forma sobredita, e o lado exte- Fig. ${ }^{a} 76$ Est.37 rior $\mathrm{EF}$, este se parta em tres partes iguais; tomem-se as capitays FM, EN iguais cada huma a dita terça parte de EF; tirese tambem a linha $\mathrm{MN}$ que será igual a $\mathrm{EF}$, partase tambem esta em tres partes iguais a saber $\mathrm{NA}, \mathrm{AB}$, e $\mathrm{BM}$, e estas determinarão a cortina $\mathrm{AB}$, e as duas demigolas AN, e BM; para determinar os flancos se tirem as linhas $\mathrm{ME}, \mathrm{NF}$; tomese a distancia perpendicular que ha do ponto $\mathrm{R}$ onde estas linhas se cruzão athe a cortina, e igual a elle se levantem os flancos $\mathrm{AD}, \mathrm{BC}$ perpendiculares a cortina; finalmente dos pontos $\mathrm{D}$ e C, extremos dos flancos, se tirem as faces DE, CF, e ficará desenhado o hornaveque que se costuma fabricar defronte da cortina na fortificação regular: a deligniação dos outros se obrará por semelhante methodo tendo sempre respeyto ao lugar.

\section{Nota}

Nas operações sebreditas se involvem [sic] duas praxes, a primeyra quando a cortina he determinada pellas faces; a segunda em que as faces se determinão pella cortina.

\section{Por outro modo.}

Levantemse dos angulos da espalda da praça A e C duas per- Fig. ${ }^{a} 77$ Est. 38 pendiculares com $\mathrm{AB}$, e $\mathrm{CD}$, cada hu'a de 720 pés [237,6m], ou ainda mais se a necessidade de descobrir alguma bayxa o pedir; lancesse a linha $\mathrm{BD}$ a qual se parta pello meyo; e nos ramais DC, e BA se tomem as duas porções DG, e BF cada hu'a igual com a metade da dita linha DB; dos pontos $\mathrm{G}$ e F se tirem as duas linhas $\mathrm{FD}$, e GB as quais se cruzarão no ponto N; partão-se as linhas NB, 
e ND pello meyo nos pontos $\mathrm{H}$, K, e ficarão determinadas as faces $\mathrm{HD}$, e KB; o que assim feyto, partase a cortina da praça em duas partes iguais no ponto $\mathrm{L}$, do qual se tirem aos pontos $\mathrm{H}, \mathrm{K}$ as linhas LH, LK que cortarão as linhas da defença nos pontos M e I, e assim tirada a linha IM será esta a cortina, e os flancos serão MK, IM com que ficara desenhado o hornaveque.

Fig. ${ }^{a} 77$ Para se the fazer o seu revelim defronte da cortina não ha mais que produzir a cortina IM athe topar com os ramais nos pontos $\mathrm{O}$, e P, depoys tomar a distancia PI ou MO, e com esta das extremidades da cortina IM como de centros se descrevão dous arcos que se cruzem no ponto X, o qual será o extremo da capital, e deste ponto $\mathrm{X}$ tirando as linhas $\mathrm{XV}$, e $\mathrm{XZ}$ em direytura dos pontos $\mathrm{P}$ e $\mathrm{O}$ athe a contraescarpa e ficará deligniado o revelim, que no mais será como o do corpo da praça.

Pareceme bastarem estes modos, quem quizer ver mais consulte a Pfeffinger, aonde achará muytos de varios auctores; ao Engenheyro Portuguez, e ao nosso Methodo Luzitanico.

Das obras cornas diante dos baluartes.

Ja dissemos que estas obras cornas feytas defronte dos angulos flanqueados, devem os seus ramais principiar mais estreytos da parte da praça, e hirem alargando para a parte da campanha, para tomarem algu'a defença das faces do baluarte porque sendo parallelos tomão muyto pouca da cortina; a sua deligniação Fig. ${ }^{a} 78$ Est. 38 he na forma seguinte.[:] Produzase a capital do baluarte de A athe B couza de 520 , athe 540 pés $[171,6 \mathrm{~m}$ até $178,2 \mathrm{~m}]$, para hu'a e outra parte do ponto B se levantes [sic] duas perpendiculares como por exemplo BC e BD, cada hu'a de 156 pés [51,48m]; sobre os extremos destas ditas perpendiculares D e C se levantem outras de 
96 pés $[31,68 \mathrm{~m}]$, como $\mathrm{DF}$ e $\mathrm{CE}$; dos pontos $\mathrm{C}$ e $\mathrm{D}$, que são os angulos da defença ou flanqueantes se tirem pelos pontos $\mathrm{E}, \mathrm{F}$, as linhas DEH, e CFG de E para H, e de F para G se tomem de 150 athe 180 pés $[49,5 \mathrm{~m}$ até $59,4 \mathrm{~m}$ ], e serão as faces $\mathrm{EH}, \mathrm{FG}$, e dos pontos $\mathrm{G}, \mathrm{H}$, se tirem duas linhas ao meyo das faces do baluarte e estas serão os ramais que se terminarão na estrada encuberta junto a contraescarpa; o mais se fará como na obra corna defronte da cortina, com seu revelim sendo necessario.

Fazemse tambem estas obras cornas em cazo de necessidade mais avançadas a campanha para descobrir algu'a bayxa, em que o inimigo se pode ocultar, e então se lhe acrescenta hu'a coroa, e se lhe flanqueão os seus ramais; vejase Pfefinger [sic] liv. 3. Cap. 12 pag. 164.

\section{Das tenalhas.}

\section{O lugar da tenalha he o mesmo que o do hornaveque} defronte da cortina, rarissimas vezes se fazem defronte do angulo flanqueado a respeyto de sua muyta fraqueza. A sua deligniação para a tenalha simples he a seguinte.[:]

Lancem-se os ramais AC e BD, do mesmo modo que se exe- Fig. ${ }^{a}$. Est. 39 cutou para a fabrica dos hornaveques, excepto que devem ser menores, a saber de 450 , athe 550 pés [148,5m até $181,5 \mathrm{~m}$ ]; ajuntem-se os dous ramais com a linha DC, a qual se parta pello meyo no ponto $\mathrm{F}$, do qual se levante a perpendicular FE para a parte da praça, igual á quarta parte de $\mathrm{CD}$; tirem-se as linhas $\mathrm{CE}, \mathrm{DE}$, com as quais fica descripta a tenalha simples.

Para se fazer a tenalha dobre se tirem os ramais na mesma forma que se fes para simples $\mathrm{AC}$ e BD, ajunteselhe a linha CD a Fig. ${ }^{a} 80$ Est. 39 qual se parta pelo meyo no ponto $\mathrm{G}$, deste dito ponto $\mathrm{G}$ se levante 
a perpendicular GE tambem para a parte da praça e igual a hum quarto de $\mathrm{CD}$; tirem-se as linhas $\mathrm{CE}, \mathrm{DE}$; produzase a perpendicular EG para a parte da campanha tanto que GF seja a metade de GE; cortem-se as linhas CE e DE pelo meyo nos pontos $\mathrm{K}, \mathrm{H}$ e tirem-se do ponto $\mathrm{F}$ as linhas $\mathrm{FK}$, e FH, e será ACKFHDB a tenalha dobre.

Estas obras são muyto inferiores aos hornaveques, porque nos angulos reintrantes tem o inimigo hum espaço quadrangular donde não póde ser offendido de nenhuns [sic] tiros dos defensores, excepto com granadas que se lhe lanção de sima do parapeyto, e assim só se devem fazer quando não ha tempo para outra obra, e sempre he conveniente por-lhe diante hum revelim, o qual se descreverá na seguinte forma.[:]

Fig. ${ }^{a} 81$ Est.40 Tirese a capital EK igual a ametade de qualquer das faces da tenalha como DF, ou FC; do ponto $\mathrm{E}$ se tirem as faces do dito revelim em direytura do meyo das referidas faces da tenalha $\mathrm{I}$, e $\mathrm{H}$, athe toparem com a contraescarpa do seu fosso, e ficará descripto o tal revelim, cujo fosso terá somente de largo a metade da largura do fosso da tenalha.

\section{Das coroas}

As coroas ou obras coroadas, se costumão fabricar nas mesmas partes que os hornaveques, supposto que estas obras podem cobrir mayor parte da praça do que occupão os hornaveques, e muytas vezes se fabricão a roda delles, mas o seu uso principal he para cobrir e occupar alguns padrastos, ou outeyros que de fora dominão o corpo da praça, a respeyto de que o inimigo se não senhoree delles, com grave detrimento da mesma praça. 


\section{A sua deligniação he na seguinte forma.[:]}

Como a coroa he parte de alguma fortificação regular devese observar primeyro que figura se accommoda melhor, e mais propriamente ao sitio que se ha de fortificar, e occupar com a coroa, e havendo observado esta figura, isto he, vendose no lugar se se accommoda melhor hum pentagono ou exagono etc. deligniem-se tantos baluartes dessa figura elegida quantos couberem no dito lugar, observando que os angulos dos meyos baluartes não sejão menores de 60 graos, nem mayores que recto. Costumão tambem estes baluartes serem mais pequenos que os da praça principal, o que assim supposto descrevamos principalmente a construcção de huma coroa que tenha hum so baluarte inteyro.

Produzase indefenitamente a capital do baluarte, e se a co- Fig. ${ }^{a} 82$ Est. 40 roa se houver de fundar defronte da cortina, do meyo desta se levante hu'a perpendicular tambem indefenita; na capital produzida se tomem de B angulo flanqueado do baluarte para D 450 athe 460 pes [148,5m até $151,8 \mathrm{~m}]$, e na perpendicular que se levantou da cortina se podem tomar de 700 athe 750 pes [231m até $247,5 \mathrm{~m}$ ], porque assim ainda os lados da coroa ficão dentro do tiro de mosquete que se atirar dos baluartes da praça. Logo no ponto $\mathrm{D}$ da recta $\mathrm{BD}$ se faça o angulo BDI que seja igual a ametade do angulo da figura que se quizer accommodar no sitio, e para a outra parte do mesmo ponto $\mathrm{D}$ se faça o angulo BDK igual a outra ametade do angulo da figura, e ficara todo o angulo IDK igual ao angulo inteyro da figura elegida: isto feyto nos lados do dito angulo ID, e DK se tomem $450,500,[148,5 \mathrm{~m}$ e $165,0 \mathrm{~m}]$ ou quando muyto 600 pes [198m]; dos extremos I e K se tirem as linha IM, KM em direytura dos flancos do baluarte, e ficarão determinados os lados da coroa IM, KM pelo parapeyto da estrada encuberta; mas se estes lados 
MI, MK excederem o tiro de mosquete, neste cazo será percizo [sic] encurtar mais a capital BD.

Veja-se logo a que angulo da figura regular se iguala, ou aproxima o angulo KDI, supponhamos por exemplo que he igual, ou proximo ao de hum heptagono, fortifiquemse neste cazo os dois lados DI e DK pellas proporções ensinadas do heptagono, e ficará feyta a coroa com o baluarte inteyro DHG no meyo, e os dous meyos baluartes nos lados MIF, MKO.

Se a coroa houver de ter mais baluartes inteyros por assim importar, os lados da dita coroa se lancem de qualquer parte defronte da cortina donde tomem defença, mas com tanto que nunca excedão o tiro de mosquete, e dentro desses lados se fação os baluartes necessarios com a proporção da figura que melhor se accommodar naquelle lugar.

Por outro modo para as coroas defronte da cortina.

Do extremo da Capital do revelim (sendo que o haja) se levante hu'a perpendicular para a campanha de 600 pés [198m], e nos poligonos de mais de sete lados se póde estender athe 660 [217,8m], e ainda mais segundo o pedir o sitio que se quer occupar, e seja esta a linha $A B$.

Fig. ${ }^{a} 83$ Est. 41

Advirtase que no cazo que não haja revelim se deve formar sobre a cortina da praça hum triangulo equilatero, cujo angulo do vertice reprezentará o extremo da capital do revelim.

Do ponto B para hu'a e outra parte se descrevão dous arcos com a distancia de outros 600 pés; dos angulos da espalda sobre as faces se tomem de 24 athe 36 pés [7,92 até $11,88 \mathrm{~m}$ ] e se signalem os pontos $\mathrm{C}$ e $\mathrm{D}$, dos quais com a distancia de 670 pés [221,1m] se descrevão outros dous arcos que cortarão os primeyros nos pon- 
tos E, F; lancem-se as linhas BE, BF, e os ramais se tirem dos pontos $\mathrm{E}, \mathrm{F}$, em direytura dos pontos $\mathrm{C}$ e $\mathrm{D}$ que se tomarão nas faces, athe toparem com a contraescarpa. Partam-se pello meyo as linhas $\mathrm{BE}, \mathrm{BF}$, e dos pontos medios $\mathrm{G}, \mathrm{H}$, se levantem perpendiculares para a parte da praça de 90 athe 120 pés [29,7m até $39,60 \mathrm{~m}$ ], como GI, e HK; tirem-se as linhas da defença pellos pontos I e K; tomemse dos pontos E e F 186 pés [61,38m] para as faces, e 96 [31,68m] para complemento da linha da defença, de cujos extremos se tire a cortina, e dos desta se levantem os flancos, e ficará desenhada a coroa.

Por outro modo tambem para defronte das cortinas.

Do ponto medio da cortina do corpo da praça se levante hu'a Fig. ${ }^{a} 84$ Est.41 perpendicular de 1060 pes [349,8m], como por exemplo AB; do mesmo ponto medio $\mathrm{A}$ com a mesma distancia $\mathrm{AB}$ se descreva hum semicirculo; e do ponto B se tomem para hu'a e outra parte 560 pés, como $\mathrm{BC}$ e $\mathrm{BD}$, ás quais se lhe tirarão linhas parallelas em distancia de 135 pés $[44,55 \mathrm{~m}]$, as quais parallelas se terminarão nos ramais que se tirão dos pontos $\mathrm{C}$ e D em direyto dos angulos da espalda $\mathrm{O}, \mathrm{P}$, athe topar na contraescarpa; dividaose estas parallelas em quatro partes iguais, e servirá cada hu'a dellas para demigolas, como EF, EG, KL, e IH, e as duas que ficão serão para as cortinas GK, e FI; dos pontos K, G, F, I se levantem os flancos perpendiculares ás mesmas cortinas, e estes serão terminados pelas linhas da defença razante, as quais tambem determinarão as faces, e fica descripto a coroa. 
Produzase a capital do baluarte outro tanto como a cortina, como por exemplo AB sobre esta linha se faça para hu'a e outra parte hum triangulo equilatero como $\mathrm{ABC}$, e $\mathrm{ABD}$; dividaose os lados $\mathrm{BC}$ e $\mathrm{BD}$ em cinco partes iguais, tome-se hu'a destas para as demigolas, e ficão tres para as cortinas; para as capitays se produzão os lados $\mathrm{AC}$ e $\mathrm{AD}$ athe que $\mathrm{CG}$ e $\mathrm{DE}$ sejão iguais dous quintos de $\mathrm{DB}$, ou $\mathrm{BC}$, e tambem a capital BF seja igual aos mesmos dous quintos; tirem-se ultimamente as linhas da defença razantes, e levantando os flancos dos extremos da cortina, estes determinarão as faces; dos pontos E e G se tirarão os ramais EL, GM, em direytura dos angulos da espalda do baluarte, athe se encontrarem com a contraescarpa do fosso.

Outro modo de coroas com espaldas

Póde succeder que não baste hu'a coroa para cobrir algum posto ou valle mais fundo, por não estender os seus ramais tanto que fiquem fóra do alcance do tiro de mosquete, neste cazo se the farão espaldas na forma seguinte.[:]

Do angulo do parapeyto da espalda se levantem perpendiculares para a campanha de 900 athe 1500 pés [297,0 até $495 \mathrm{~m}$ ], como por exemplo AB, e CD; cortem-se destas perpendiculares de 600 athe 900 pés [198,0m até $297,0 \mathrm{~m}$ ] conforme for o seu comprimento, como AE, CF; levantemse dos pontos E, F, para a parte da campanha as perpendiculares EH, FG de 120 pés [39,6m]; dos pontos $\mathrm{G}, \mathrm{H}$, se tirem os ramais em direytura dos pontos $\mathrm{A}$ e $\mathrm{C}$ the toparem com a contraescarpa; dos pontos $\mathrm{G}$ e $\mathrm{H}$ se tirem outras perpendiculares athe toparem as linhas $\mathrm{AB}, \mathrm{DC}$, como HI, GK; 
isto feyto, sobre os pontos B e D se descrevão dous angulos cada hum de 120 graos, e produzindo os seus dous lados da parte da campanha, estes se encontrarão no ponto L; com a distancia BL, ou DL se faça do ponto L para a parte da praça o triangulo iscoceles [sic] BMD, cujo vertice será o ponto M; deste ponto se tirem pelos pontos B, L, D, as capitais indefinitas; partase qualquer dos lados interiores $\mathrm{BL}$, ou $\mathrm{LD}$, em quatro partes iguais, e se tomará hu'a destas para cada demigola, e outra para flanco, o qual com a cortina formará angulo de 100 graos: ultimamente pellas extremidade dos flancos se tirarão as linhas razantes athe encontrarem as capitais, e ficarão deteminadas as faces.

O resto se faz como nas outras obras exteriores, excepto que a grossura do parapeyto dos flancos HI e GK não tem mais que nove pes, para que a face do baluarte se possa facilmente arruinar no cazo que o inimigo se chegue a fazer senhor da obra.

\section{Das meyas Luas}

\section{Ja dissemos que as meyas luas differem muy pouco dos} revelins, e acrescentamos agora, que o seu angulo não seja menor de 60 graos, nem mayor de 90; que a sua altura seja mediocre, e que fiquem apartadas do reparo principal menos de tiro de mosquete, para que se possão bem defender, e offender ao inimigo: sempre devem ter capacidade para alojar 150, ou ao menos 100 soldados; a sua deligniação he a seguinte.[:]

Da linha capital QV produzida se corte ou tome alem do fosso Fig. ${ }^{a} 87$ Est.43 a porção ZX igual aos dous terços da face do baluarte ZV, e dos pontos $\mathrm{H} 4$ nos quais se encontrão as linhas das demigolas dos revelins que deve haver de huma e outra parte se lancem ao ponto $\mathrm{X}$ as duas linhas rectas $\mathrm{HX}, 4 \mathrm{X}$; produzãose as faces do baluarte $7 \mathrm{~V}$ 
athe que cortem as linhas $\mathrm{HX}, 4 \mathrm{X}$ nos pontos 8 e 9, e o arco formado pella contraescarpa nos pontos 3 e 3 ; ou tambem em lugar das faces produzidas se tirão as fixantes $2 \mathrm{~V}, 6 \mathrm{~V}$, porque estas produzidas determinarão as faces, e flancos da meya Lua, os quais flancos se não costumão fechar, e assim ficará deligniada a meya Lua.

Tambem succede haver occazião em que estas se fabricão de fronte das cortinas, e então se tira a capital do meyo dellas perpendicular a mesma cortina, e a deligniação destas he semelhante á dos revelins.

Entre as obras exteriores he esta a mais debil, assim por não ser capaz de grande numero de defensores, como por se defender mais dificultozamente da praça, e assim só se devem admitir com as circunstancias seguintes. [:] Primeyra que de hu'a e outra parte tenhão revelins que as defendão; segunda que somente constem de faces, sem flancos, porque de outra sorte sendo ganhadas pello inimigo não poderá este ser offendido dos revelins.

Finalmente que fiquem muyto dentro do tiro de mosquete, como dissemos no principio, e ainda assim havendo tudo isto, he a sua utilidade duvidoza, por cuja razão se não devem fazer sem alguma particular necessidade.

Não falta quem para mayor cautella queyra que se fação minadas, porque no cazo de que o inimigo as chegue a ganhar, não podendo ser recuperadas se possão desmantelar por meyo das ditas minas.

Fazem-se estas por hum corredor de abobeda de cinco ou seis palmos [1,1m ou $1,32 \mathrm{~m}]$ de vão encostado a parede da contraescarpa, com entrada pello fosso: será bom que na parede contraria que fica encostada á terra se fassão [sic] alguns arcos que fique vazio o seu vão para por dentro delles se poder abrir a 
camera para a polvora quando seja necessario, e melhor será que o corredor se continue pella capital da meya Lua.

Outros em lugar destes corredores fazem hum posso no sentro [sic] da meya Lua (o mesmo he nos baluartes) dentro do qual escutão o roido dos mineyros do inimigo, e tratão de hirem a encontralos para os estorvar como se dirá na defença das praças em capitulo particular das contraminas: de qualquer modo o intento he facilitar o trabalho, tendo feyto antecipadamente tudo o que puder ser para que quando seja necessario voar alguma destas obras reste só meter a polvora, e darlhe fogo; ou ao menos que reste pouco que fazer para conseguir este intento.

Quem quizer ver outra construcção bem mais apurada, entre muytas que trazem varios auctores, consulte o nosso Methodo Luzitanico parte $1^{\text {a }}$ secção $1^{\text {a }}$ Cap $^{0} 19$ pag. 73 .

Das caudas de andorinha

São as caudas de andorinha (como ja dissemos) semelhantes as tenalhas simples, e a sua differença consiste so nos ramays em serem huns parallelos e outros não; o seu desenho he produzir os flancos para a parte da campanha 660 pes [217,8m] quando estes são perpendiculares á razante, mas sendo-o á cortina, se tirarão os ramays com a mesma distancia dos angulos da espalda, de sorte que com as faces dos baluartes formem angulos de 60 graos; e o mais se obra como na tenalha simples.

$\mathrm{O}$ pequeno revelim he tambem semelhante, e semelhantemente feyto ao que se poem diante das ditas tenalhas simples.

Monsier Ozanam faz o seguinte desenho.[:] Dos angulos da Fig. ${ }^{a} 88$ Est.44 espalda se levantem para a campanha perpendiculares á cortina do comprimento que quizerem com tanto não exceda o tiro de mosquete, 
como por exemplo $\mathrm{AB}$, e $\mathrm{CD}$; lancese a linha recta $\mathrm{DB}$, e do seu ponto medio $\mathrm{F}$ se levante para a parte da praça a perpendicular $\mathrm{FG}$ igual a terça parte de BF; dos pontos $\mathrm{B}$ e D se tirem ao meyo da cortina $\mathrm{E}$ as rectas $\mathrm{BE}$, e $\mathrm{DE}$, the toparem com a contraescarpa do revelim, e ultimamente se tirem dos pontos D e B as linhas DG, e $\mathrm{BG}$, e ficara o desenho concluido, e o mais se faz como no revelim.

Dos barretes de clerigo.

Fig. ${ }^{a} 9$ Est.44 Ja dissemos tambem que os barretes de clerigo são semelhantes as tenalhas dobres, e que so differem dellas, em terem os seus ramays mais abertos da parte da campanha, e mais fechados da da [sic] praça; a sua construcção he facil, porque não ha mais que fazer huma cauda de andorinha como fica descripta asima, cujas faces AC, EC se partão pello meyo nos pontos B e D; do ponto $\mathrm{C}$ se levante para a campanha a perpendicular CF de 270 pés $[89,1 \mathrm{~m}]$; do ponto $\mathrm{F}$ se tirem as faces $\mathrm{FB}$, e FD, e todas as mais medidas são como no revelim, e ficará concluido o barrete.

O mesmo Ozanam faz o seu desenho nesta forma;[:] façase a cauda de andorinha pello seu modo ensinado; partãose pello meyo as faces $\mathrm{AB}$, e $\mathrm{BC}$; partase huma destas ametades em tres partes iguais, e se levante do ponto B para a parte da campanha a perpendicular BD igual ás duas terças partes de $\mathrm{AB}$, e do ponto $\mathrm{D}$ se tirem as duas faces $\mathrm{DE}, \mathrm{DF}$ ao meyo das primeyras faces, e se faça o resto como no revelim.

Das contraguardas.

Ultimamente as contraguardas dissemos serem semelhantes ás meyas Luas, excepto que se não fazem tão avançadas a campanha: fazem se so defronte do angulo flanqueado para me- 
lhor cobrir o baluarte impedir a chegada do mineyro, e a limpar a parte da estrada encuberta que fica defronte do angulo flanqueado e faces do baluarte, e sempre se fazem parallelas a contraescarpa do fosso principal, tirando as suas faces da contraescarpa do fosso do revelim em distancia de 24 pes [7,92m]; outros querem que seja de ametade da golla do baluarte, e o Conde de Pagan quer que seja de 9 pes [2,97m]; a capacidade do sitio ensinará a fazella mais ou menos restricta, como parecer melhor.

Temos dito athe aqui o que nos parece bastar a cerca de toda a sorte de obras exteriores; quem ainda se não satisfizer, e quizer ver outros diversos modos de as desenhar, consulte ao nosso Methodo Luzitanico, ao Engenheyro Portuguez, e a Pfeffinger, aonde achará com que satisfazer ao seu dezejo, e muyto em que aprender.

Tambem encontrará nos ditos auctores diversos perfiys, e poderá usar daquelle de que mais agradar.

$\operatorname{Cap}^{\circ} 22^{\circ}$

DAS TRAVEÇAS.

Toda a mais sorte de obras differentes das ja descriptas nos capitulos antecedentes, e que particularmente não são nomeadas com nome proprio se chamão traveças, como são as linhas fortificadas em forma de hum parapeyto sobre algum dique, ou avenida para impedir a passagem.

He esta huma boa defença para fortificar commodamente, e com grande preça [sic] qualquer posto principalmente quando o inimigo assalta de improvizo, e que não ha lugar de levantar qualquer forte. 
Sam tambem estas traveças muyto uteys e proveytozas na campanha, honde ha lugares paulozos, e passagens estreytas.

Do mesmo modo tem grande uso para fortificar as pontes, portas, e mais passagens estreytas diante de hu'a villa ou lugar, as quais não sendo fortificadas podem subitamente ser assaltadas do inimigo.

No que toca a sua fabrica não ha regra nenhu'a certa, e que se deva seguir necessariamente; formão-se conforme a preça [sic] e o lugar a juizo do Engenheyro, para o que conduzirão muyto os seguintes exemplos.[:]

Seja por exemplo hum caminho estreyto alagado de huma e outra parte que se haja de fortificar com grande preça [sic]; isto se fará commodamente em forma de huma tenalha simples, ou dobre conforme for a largura do lugar; dividase a dita largura em outo partes iguais, e de cada lado se tome hu'a outava parte para cortina sobre Fig. ${ }^{a} 91$ Est. 46 a qual se levantem os flancos TR de outra outava parte, ou pouco menos: nos pontos $O$, que são aos $3 / 8$ de toda a dita largura se levantem perpendiculares, como OZ, cada hu'a igual a $\mathrm{OQ}$ outra outava parte; e tirando as faces $\mathrm{ZQ}$ será feyta a tenalha dobre que fecha o caminho, como se ve na figura notada a dita tenalha com a letra G.

A segunda traveça $\mathrm{H}$ he ainda mais facil; tomarseha para cada hu'a das cortinas hum terço de toda a largura do caminho e no meyo do outro terço se levantará a perpendicular XZ igual com $\mathrm{XO}$ ametade do dito terço e se tirem as faces $\mathrm{OZ}$, com que ficara cuberto o caminho.

Quando se queyra fazer a traveça em forma de hum baluarte como se ve na figura $\mathrm{Y}$ se póde tomar para as cortinas de huma e outra parte hum terço de toda a largura, e a outra terça parte para capital, igual com a demigola e os flancos iguais com a metade da dita capital ou demigola. 
Podese tambem fazer a traveça em forma de revelins como se ve na dita figura a traveça $X$ : poderseha fazer de outras mais formas, conforme ocorrer mais presto ao juizo do Engenheyro.

Da mesma sorte o perfil destas obras não tem regra certa, pella preça com que ordinaria são feytas; so he necessario advertir que seja capaz de fazer rezistencia, e que diante tenha hum fosso de quinze ou vinte pés de largo [4,95m ou $6,60 \mathrm{~m}]$, e seis athe outo de alto [1,98m até $2,64 \mathrm{~m}]$, o qual pode fenecer em bayxo em hu'a linha, sendo do feytio de huma cunha; em fim vem a ser que o perfil se faça conforme o tempo der lugar.

Ha tambem outra sorte de traveças que se fazem dentro das fortificações para retiradas, e para prevenção do danno das granadas, e ballas de fogo quando o inimigo aperta com ellas os sitiados, retirandose a gente detraz das ditas traveças, como fizerão no ultimo sitio de Bolduc honde os sitiados levantarão muytas destas traveças detraz das quais se guardavão das granadas com que se offendião; mas estas tem ainda menos fabrica, porque não são mais que huns reparos de parede, ou valado de terra quando baste para detraz delles se esconderem, e repararem do danno que de fóra the podem fazer.

\author{
$\operatorname{Cap}^{\circ} 23 .^{\circ}$ \\ DA FORTIFICAÇÃO DAS PRAÇAS SITUADAS \\ JUNTO DA AGUA, E DAQUELLAS POR DENTRO \\ DAS QUAIS PASSA ALGUMA RIBEYRA.
}

Os lugares postos junto de agua, como na margem de algum rio, ou lagoa, são de diversas sortes, porque ou o rio he tam largo que excede o tiro de mosquete ou he tão estreyto que da outra 
parte nos póde offender a mosquetaria do inimigo: tambem póde ser tal o rio ou ribeyra, que posto que no inverno, quando ha cheyas, tenha muyta largura, no verão se seque, e se possa facilmente vadear: algumas praças são situadas no meyo da agua, de que por toda a parte são cercadas, ficando como em ilha: por meyo de outras he que passa o rio, ou ribeyra: finalmente outras são situadas a borda do mar em alguma obra ou porto, e assim he necessaria diversa construcção em suas fortificações, se bem de qualquer modo que sejão tem estas praças grande ventagem a respeyto das que são postas em campanha raza, poys daquella parte que são cercadas da agua necessitão de menos reparos.

Quando a largura do rio excede o tiro de mosquete, e se não póde facilmente vadear, basta que aquelle lado da praça que fica banhado seja fortificado com redentes, com seus flancos pequenos a distancia de 400 ou 500 pés [132,0m ou 165m]: no meyo póde haver huma plataforma para com a artelheria desta se defender todo o rio contra as embarcações do inimigo quando intentem navegalo para a passagem, e ainda para mayor segurança, para que os inimigos não tomem quartel da outra parte do rio, e assim tambem nos embaracem a navegação e passagem será necessario fazer hum forte tal que per si se possa defender, e para este cazo he a prepozito fazer hum meyo quadrado, ou meyo exagono, com advertencia que o lado que olhar para a praça ficará aberto, ou somente fechado com hum leve muro quanto só baste a encanar a agua: e se da praça se puder defender com a mosquetaria a margem opposta do rio, por este não ser tão largo que exceda o tiro de mosquete, então basta em lugar do forte hum revelim, ou hum baluarte.

Sendo a ribeyra tal que no verão se seque, ou que seja tão pouco abundante que se possa vadear em tal cazo posto que banhe 
algum lado da praça deve ser tambem fortificada por esta parte como pellas outras, salvo que poderá escuzar fosso pella banda do rio.

Quando a praça for dentro de alguma lagoa se terão as mesmas conciderações a cerca da largura da agua que a cerca, de se poder ou não poder vadear para conforme isto se the dar mais ou menos robusteza em sua fortificação, assim no que toca á forma, como ao perfil, o que se julgará conforme a importancia, e circunstancia do lugar.

Póde succeder que o rio entre por dentro da praça, e neste cazo sendo tão estreyto que possa caber por hum ou dous arcos, se formarão estes no meyo de huma cortina, e se metera por elles, mas devem ser asegurados com cadeas de ferro, das quais ficará huma á superficie da agua; e para que não estorvem a passagem dos barcos quando o rio for capaz de navegação, se abayxarão de dia as cadeas, e de noute quando se fechão as portas se levantarão com algum engenho, que deve haver em hum lado destes arcos, como adverte Antonio de Ville liv. $1^{\circ}$ Cap $^{\circ} 63$.

Sendo o rio mais estreyto, e que cayba por hum ou dous arcos menores, melhor se segurão estes fechando-os com huns orgãos que cayão do alto da abobeda do arco, e para que estes orgãos fiquem seguros primeyro se lançará no fundo do rio hum alicerce de fortes pedras de cantaria que sustentem as pontas das vigas, e no vão do arco se atraveçará huma forte viga com seus pontaletes para as ilhargas que as sustentem contra a força da corrente, para que esta viga sustente as cabeças dos orgãos, que com a força da agua não puchem pellas cordas que os prendem sobre tudo da parte de dentro se fará hum pequeno corpo de guarda na entrada do rio, o qual corpo de guarda póde ser debayxo do reparo com huma janella sobre o canal, para que não possa sahir, nem entrar alguem sem ser visto. 
Podese tambem segurar esta entrada com fortes grades de ferro, e de mais com huma palissada cravados os páos no meyo da corrente do rio.

Mas porem sendo elle tão largo como toda a cortina, não he então necessario fazerlhe arcos, mas deychalo entrar francamente, e da mesma sorte sahir: he com tudo so necessario de huma, e outra parte do canal levantar hum parapeyto com seus redentes, ficando a praça fortificada á parte de cada huma das duas margens do rio, com hu'a ponte no meyo para comonicação de hu'a para outra fortificação, a qual ponte com seu parapeyto póde tamber [também] servir para defender o rio com mosquetaria, e ainda com artelheria.

Os lugares junto do mar se he alguma villa ou cidade que se queyra guardar, e os inimigos tem onde dezembarquem afastado della para a poderem accommeter, e sitiar por terra, nem este dezembarque se póde ivitar [sic] com hu'a ou duas fortalezas, neste cazo necessita a tal cidade de ser fortificada inteyramente como se fora em hu'a campanha raza, excepto que da parte do mar não carece de tantas grossuras, e tambem basta que tenha menores corpos, por esta razão não faltou quem fosse de voto que a cidade da Bahia de todos os Santos nesta America se devia fortificar real e inteyramente da parte de terra, porque não se podendo prohibir o dezembarque pela largura grande da Bahia, podião os inimigos pôr hum exercito em terra, e accommeter a cidade; e ganhala, ficando frustadas todas aquellas fortificações que so respeytão ao mar, como são aquellas que so se fazem para defença e guarda do porto; ${ }^{166}$

\footnotetext{
${ }^{166}$ Parece voz geral entre os engenheiros militares que a Cidade do Salvador tinha problemas sérios de defesa pela dimensão de sua baía. A maioria era também de opinião que a defesa deveria se circunscrever á mancha urbana da cidade, em virtude de ser difícil evitar o desembarque ao inimigo.
} 
para as quais basta eleger hum sitio donde melhor se descubra, e enfie o caminho que fazem as embarcações; e como estas fortificações não podem ser batidas do mar basta que tenhão huma boa praça para a artelheria, e se procurará que esta fique o mais bayxa que possa ser, e por tanto será bom (podendo ser) que a fortaleza tenha duas baterias huma pouco mais alta que a mayor enchente da maré, e quanto possa ser proxima a agua, ou dentro nella.

A dificuldade he nos alicerces da parte do mar quando não ha alguma penha ou recife sobre que sejão fundadas: mas sendo o sitio importante se deve buscar remedio a todas as dificuldades que se offerecerem, ainda que seja com custo, o que costuma succeder em todas as obras junto do mar.

Se o lugar para os alicerces se descobrir de maré vazia se examinará a qualidade delle se he lodo, area, ou pedra.

Sendo lodo ou area se procurará alimpar, e profundar o melhor, e mais que possa ser, athe se topar com algum terreno mais duro, e para isto se poder conseguir aconselharão, e uzarão os antigos cercar primeyro o lugar em que se havia de cavar com dous fios de estacas por cada lado bem juntas e unidas humas as outras, e tão altas como a altura da mayor enchente, as quais estacas depoys forravão de taboões de modo que ficasse feyto hum tanque dentro da agua, cujas paredes erão em forma de cayxões formados dos ditos taboões que pregavão nas estacas: enchião estes cayxões ou paredes de terra ou greda, para sustentar a agua, e para que com o pezo da terra (que deve ter grossura bastante) se não abrão os cayxões hão de ser leadas [sic] as cabeças das estacas com traveças que as prendão hu'as as outras; o que assim preparado esgotavão o tanque; ou lugar que ficava dentro destas paredes e havia de servir para fundar os alicerces, e depoys de esgotado o 
cavavão athe achar firme: e sucedendo ser necessario cavar muyto fundo, dentro neste vão fundavão outras cayxas mais fundas para sustentar as primeyras que senão arruinacem para dentro, e para impedir tambem a agua que podia brotar por bayxo das primeyras, pello que he necessario acautelar no principio que a primeyra cava se faça com largueza.

Feyta assim a cava para o alicerce todo elle cravavão de estacaria de qualquer madeyra sendo verde (entendese aqui por alicerce todo o vão da fabrica, que todo elle para bem ha de ser mociçado de bom massame de pedra e cal) e este modo póde servir para fundar dentro de hum rio os alicerces dos pillares para algu'a ponte, quando se não possa devertir o rio do seu alvio ${ }^{167}$ : mas so se deve emprender esta obra quando o rio for bayxo, porque hindo alto difficultozamente se poderá obrar de modo que se consiga a empreza.

E quando importe fundar a todo o custo dentro de algum pego, ou dentro do mar he então necessaria outra industria, e mais tempo, e assim obrarseha do seguinte modo ${ }^{168}$.[:]

No lugar onde se ha de fundar se carregará algum bayxel velho de pedra tanto athe que o pezo o leve ao fundo, e sempre sobre elle se hirá botando mais e mais pedra perdida em muytos annos, athe que o mar com sua frialdade congelando-a, e ajuntandolhe alguma area, musgo, e lodo, venha ali a criar hum torrão solido que sobrepuche [sobrepuje] por fóra da agua, o qual se hirá cada vez

\footnotetext{
${ }^{167}$ Forma arcaica de dizer desviar o rio do seu leito.

${ }^{168} \mathrm{O}$ autor descreve, em seguida, a técnica do enrocamento onde fala de usar o artifício de colocar pedras brutas sobre barcas velhas e fazê-las afundar, para ser o ponto de partida do dito enrocamento. O processo sugerido, embora curioso, não é uma idéia inusitada, pois aparece em tratados quinhentistas italianos, como o de Castriotto e Maggi: Della fortificatione delle cita. p. 77.
} 
aumentando com mais pedra perdida athe que em sima tenha bastante espaço para fundar a fortaleza, cuja muralha será revestida de pedraria athe toda a altura que a agua chegar, e ainda mais dous ou tres palmos; e este revestimento não deve ser singello, e de pedras ordinarias, mas deve de ser de pedras grandes postas com o mayor comprimento para dentro do groço da muralha, (a que chamão metidas ao tissão) e cortadas por vitola de modo que se prendão humas com as outras; a vitola póde ser do feytio que mostrão as figuras 92 Est.47 e melhor que todas as notadas com a letra $X$.

Nesta forma, e com semelhantes pedras foy feyta a torre de Sam Lourenço (chamada por outro nome a torre de Bogio) na barra de Lisboa: nesta forma se fes outra semelhante fortaleza na Bahia de todos os Santos nesta America ${ }^{169}$, nesta forma se fes outra na barra do Maranhão ${ }^{170}$, se bem esta foy mais facil, porque teve por primeyro fundamento hu'a lage que estava dentro do rio, que todavia de maré cheya se cobria com 12 e 13 palmos [3,96m e 4,29m] de agua: e nesta forma se tem feyto em outras partes, outras varias fortalezas dentro do mar: da mesma sorte com a mesma paciencia e desperdicio de tempo se formarão os molhes de Liorne [sic], de Messina, de Genova, e outras partes; e ainda que este modo pareça muyto inconstante, e incerto, como ja se tem feyto em varias partes, não se deve ter por obra perdida, ainda que no principio se veja succeder alguns desmanchos e roinas, mas devese ter constancia e paciencia, que estas, e o trabalho tem vencido grandes dificuldades.

\footnotetext{
${ }^{169}$ Está referindo-se à Fortaleza de Nossa Senhora do Pópulo e São Marcelo, conhecido também como Forte do Mar, no porto de Salvador. Sobre esta semelhança construtiva e de projeto tivemos oportunidade de fazer um estudo intitulado Morfologia dos fortes do mar da defesa de Salvador.

${ }^{170}$ Trata-se, certamente, do Forte da Barra, ou da Ponta de João Dias, em S. Luiz.
} 


\section{$\operatorname{Cap}^{0} 24 .^{\circ}$ \\ DOS FUNDAMENTOS, E ALICERCES \\ DAS MURALHAS.}

Rezervey para o fim desta segunda parte orthografica o tratar do fundamento e alicerces das muralhas, por me parecer o seu proprio lugar, poys he sem duvida que depoys de explicar toda a sorte de fortificações que se costumão fazer com seus perfiys, que diviamos então dizer o como se poem em execução; e sendo os alicerces a primeyra obra que se principia a executar por elles he tambem de razão que principiemos esta instrucção.

Não se devem as muralhas principiar a cazo, e donde quer se offerecer, mas devese conciderar com bastante cuydado a firmeza do terreno para se fundarem, porque por esta cauza não venhão depoys a padecer roina, como muytas vezes tem sucedido a edificios de grande fabrica, poys assim como as raizes das grandes arvores he necessario que prendão em terra firme, e que sejão groças e profundas, para que o tronco não aballe e caya da mesma sorte as muralhas he percizo [sic] que tenhão alicerces solidos, e largos para que não venhão finalmente aruinarse.

Por tanto Vetruvio (mestre sem duvida da Architectura civil) ${ }^{171}$ tratando dos alicerces das muralhas no Liv. $1^{\circ}$ Cap $^{\circ} 5^{\circ}$ dispoem que se cave tanto athe que se ache o terreno duro e firme, para cujo conhecimento se costuma fazer experiencia metendo-o em agua e tendo-o nella por espaço de hum dia, que se não se molificar, e desfizer he signal que he duro e firme, e por tanto dizem os Architectos que senão póde achar melhor firmeza para

\footnotetext{
${ }^{171}$ Neste caso Vitrúvio é citado textualmente, mas, ao longo do texto de Vellozo, está clara a influência deste antigo tratadista nos seus conceitos de construção e de arquitetura.
} 
alicerces que quando se achão aguas nascentes dentro da terra, porque o terreno por bayxo do seu nascimento he o mais seguro.

São tambem indicios de terreno firme se elle he duro de cavar, se donde se ha de fundar não nascem ervas costumadas a nascer em lugares humidos, se ahi não nascem arvores, ou nascem so aquellas que costumão nascer em terrenos duros, se o paiz á roda he seco e pedregozo que não haja perto aguas vertentes, porque estas com sua correnteza sempre trazem algum terreno movediço, e menos firme; se ao caminhar de carros e cavalos não soa o terreno onde se ha de fundar, ou perto delle, o que se conhece com hum vazo de agua se esta se não move batendo o terreno afastado della; o mesmo he lançado de alto sobre a terra grandes pedras, e outros pezos ${ }^{172}$.

Cavarsehão os alicerces mais largos do que ha de ser a muralha; alguns architectos dispoem que se cavem mais largos ametade, e ainda em alguns lugares mais; o que nas muralhas da fortificação seria muyto; a experiencia tem mostrado que basta deyxarlhe hum sepo a que outros chamão sapata de hum pé $[0,33 \mathrm{~m}]$, ou dous palmos $[0,44 \mathrm{~m}]$ mais largo que o resto da muralha, o qual sepo ficará no livel do fundo do fosso, e dahi para bayxo hirá o alicerce aplumo, quando por poupar o gasto se não queyra darlhe tambem alguma escarpa ao menos da parte exterior: o fundo do alicerse será muyto bem alivelado e limpo, ou antes com algum declive para a parte de dentro, para que a muralha peze contra o terrapleno, e esta deligencia de aplaynar o fundo do fosso se não escuzará ainda no cazo que a muralha seja fundada sobre rocha, ou quaisquer penedos sempre se aplaynarão para fazer leyto a muralha,

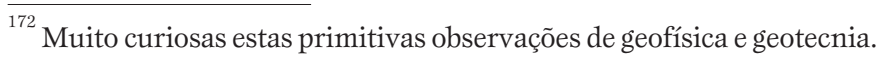


e se não se puder aplaynar toda a largura bastará que seja em bancos como degraos, e se hirá engroçando a parede sobre elles; e o mesmo ha de ser quando suceder ser necessario que a parede corra a traynel com o alicerse mais fundo de huma parte que de outra, que então se farão tambem os mesmos bancos pello comprimento da parede, de modo que sempre cada lanço fique alivelado no fundo onde começará a fundar com pedras das mayores que se puderem haver, e com boa cal.

Se o fundo do alicerce for pouco firme, e paulozo se cravará de estacas em dobrada largura do que ha de ser a parede, e as ditas estacas terão de comprido ao menos a outava parte do que ha de ser a altura da muralha, e terão de grossura o que corresponde á duodecima parte de seu comprimento antes mais que menos; cravarsehão miudas, metendo entre ellas outras estacas menores, athe que não fique lugar de meter mais ${ }^{173}$; cavilharsehão com outros paos atraveçados, e principalmente por fora, enchendo os vãos com cal e cascalho de pedra miuda, e por sima boas lages compridas e largas.

$\mathrm{O}$ instrumento para pregar as estacas seja qualquer que for não he necessario que o seu masso seja muyto pezado, porem que dê amiudados golpes, porque os que são muyto pezados quebrão e espedação as estacas, e o continuar os golpes amiudo vence toda a dureza e rezistencia do terreno, como se experimenta quando se quer pregar hum prego sutil em hum madeyro duro, que se se obrar com hum martello pezado não sucede tam bem como com hum pequeno, e com repetidos golpes.

\footnotetext{
Os ensinamentos são de Leon Batista Alberti no De Re Aedificatoria, que Vellozo cita textualmente em outras passagens: Si configgano molti pali e pertiche, dalla cima abrustolita, com la base rivolta in alto, in maniera tale Che l'area di quest'opera venga larga il doppio di quella che dovrà essere il muro; i pali devono essere lunghi almeno 1/8 dell'altezza che si vuol dare al muro, e grossi non meno di 1/12 della propria lungezza.
} 
Se cavando o alicerce se acharem aguas nascentes he muyto necessario ao fundar não poupar a cal, mas lançala em quantidade so traçada com area seca depoys de pregadas as estacas onde forem necessarias.

Estas poucas advertencias bastão para insinuar que os alicerces se devem fazer com toda a cautella, e deligencia, tomando primeyro boas informações dos praticos do paiz acerca da firmeza do terreno, e da forma em que se obrarão os alicerces de edificios que hajão durado muyto tempo.

So resta dizer que póde muytas vezes ser util por poupar gastos, ou talvez por evitar a fraqueza do terreno não fundar com hu'a so continuada cava, continuando a muralha em todo o alicerce, mas deychando alguns intervalos, como se se houvessem de plantar so pilares, ou columnas, onde formando arcos sobre os ditos pilares, sobre estes se forme o resto da muralha; mas quando houver de carregar mayor pezo sobre os ditos arcos, tanto mais robustos devem ser os pilares ${ }^{174}$.

\section{$\mathrm{Cap}^{\circ} 25$. \\ DA ESCOLHA DOS MATERIAYS PARA} A FABRICA DA MURALHAS.

Supposto que o conhecimento da bondade dos materiays mais toca aos mestrres [sic] e officiays que os manejão, e com elles obrão, e assim delles he que se deve tirar esta informação, com

\footnotetext{
${ }^{174}$ É um sistema construtivo interessante do qual já temos notícia desde os tempos medievais. São construídas umas espécies de tubulões, de secção quadrada, a intervalos regulares e, em seguida, ligados por cima um aos outros por arcos que vencem a distância entre eles e sobre estas arcadas sobem as paredes do edifício.
} 
tudo para poder julgar da bondade da obra, para ver se o mestre tem, satisfeyto á sua obrigação, e por de algum modo poder evitar os enganos que elles costumão fazer nas obras que tomão de empreytada ${ }^{175}$, he necessario que o Engenheyro que assiste as tays obras seja vegilante, e acautelado em os examinar, poys todo o engano nesta parte succede em danno da obra que elle deve zelar.

Os materiays comuns são pedra, cal, e area, e tambem tijollo: primeyramente em quanto á pedra he escuzado fazer tantas differenças como traz Vetruvio liv. $2^{\circ} \mathrm{Cap}^{\circ} 8^{\circ}$, porque para as fortificações nos devemos valer daquellas que mais promptamente offerece o paiz, ou talvez se achão dentro nos mesmos fossos, que com isso se segue o proveyto de os abrir, e se poupa o grande custo das conducções, porem he bom o sabellas accommodar bem na obra, segundo sua qualidade, porque hu'as são boas em hum lugar, outras em outro: as pedras vivas mais duras e mayores se meterão nos alicerces, e lugares mais humidos; as pedras mortas, e que tem especie de saybro, ou barro se não porão a face, mas servirão so para enchimento do groço da parede, ja fora do alicerce, e donde não houver humidade, porque metendo-se de sorte que fiquem ao ar principalmente em lugares que olhão para a marinha, ou lagos, ou para a parte do sul se consomem, e desfazem pouco e pouco; e são offendidas das giadas e nevoas, com que nesta parte da face da parede se porão as pedras de melhor temperamento quais são as que se achão logo no principio das pedreyras, que ao quebrar são mais brandas, e com o tempo se endurecem, e rezistem a todas as injurias do tempo.

\footnotetext{
${ }^{175}$ Forma "politicamente correta" de fazer referências às constantes falcatruas que cometiam os empreiteiros nas obras públicas, cuja documentação é extensa no particular.
} 
As pedreneyras segundo Vetruvio liv. $2^{\circ}$ Cap $^{\circ} 7$ sofrem muyto o ar [sic], e todo o grande pezo, mas com o fogo estalão e fazem aruinar a obra, mas este perigo so se temerá nos edeficios civiys [sic], na disgraça de algum incendio ${ }^{176}$.

Diz mais o dito Vetruvio, que as pedras com que se ha de fazer a muralha se quebrem no estio, e se tenhão descubertas por espaço de dous annos, e depoys de estarem provadas que no dito tempo não descobrirão alguma maldade, então se obrará com ellas: as mais asperas são melhores que as mais lizas, e lustrozas, e que banhadas de agua se não enchugão logo, porque estas não fazem boa preza com a cal o que sucede tambem com as pedras que ja estiverão postas em obras.

São tambem melhores as pedras cavadas da pedreyra, que aquellas que se achão sobre a superficie da terra, e nos alvios dos rios: as que banhadas em agua ficão muyto pezadas não durão em parages [sic] humidas: as espumozas como pedra pomes prendem belissimamente com a cal, e fazem a muralha como se fora de hu'a so pedra: finalmente se distinguirão as boas das roins observando as muralhas antigas, havendo porem respeyto a os varios aspectos do Ceo [céu], aos ventos, mares, ou outros lugares a que as muralhas estão voltadas, porque daqui nasce muyta cauza da corrupção das pedras.

Acerca da cal diz Vetruvio liv. $2^{\circ} \mathrm{Cap}^{\circ} 5^{\circ}$ que ella se deve fazer de pedra branca, e que aquella que for de mais forte e dura pedra será mais util para as muralhas; Catão Sensurino ${ }^{177}$ reprova a cal feyta de varias castas de pedra, quando seja misturada, e que a de seyxo he de todo inutil; escreve Leão Baptista Alberto liv. $2^{\circ}$ Cap $^{\circ}$

\footnotetext{
${ }^{176}$ É o que chamamos, atualmente, no estudo da degradação dos materiais de stress térmico. O assunto das pedras vem tratado no Livro II de Vitrúvio.

${ }^{177}$ Além de conhecedor dos tratadistas antigos de arquitetura o nosso autor conhecia autores antigos como Catão, o censor.
} 
$11^{\circ}$ que a cal boa deve ser a terça parte mais leve do que era a pedra de que foy feyta ${ }^{178}$, e que esta para fazer boa cal deve ser durissima, espeça e branca; e diz mais que a de cava he melhor que a outra pedra que se acha em sima da terra; e que a melhor de todas será a que se cavar de parte sombria e humida, que a de parte seca.

Para a desfazer depoys de cozida he necessario agua em abundancia, porem botandoselhe pouco e pouco, e depoys guardalla a sombra, e em lugar fresco, sem the misturar couza alguma, mais que cobrilla de area, e quanto mais tempo estiver assim guardada se fará melhor: se se quizesse guardar na mesma fornalha, ou em outra parte que estivesse ao vento, ao Luar, e ao Sol principalmente de verão se converteria em cinza, e perderia toda a força; se se obrar com ella tirada logo da fornalha não sofrerá tanta area como sendo antiga, e bem acondicionada.

A area se acha de tres sortes, a saber, a de cava, a de rios, e a do mar: a de cava a que comumente chamão os mestres pedreyros saybro he melhor que a de rios, e esta melhor que a do mar, por respeyto da mistura que tem de sal, se bem isto se poderia emmendar lavandoa em agua doce; a dos rios he melhor a que se acha nas correntes das ribeyras e outros riachos que correm de montanhas, e tem corrente impetuoza, do que a de rios abundantes, e que correm em planicies sem terem pedras em seus alvios: os signais para conhecer se he boa são, quando sobre ella não nasce erva, se apertandoa na mão ringe como sal, e não se une, e largandoa

\footnotetext{
${ }^{178}$ Isto é lógico e pode ser comprovado quimicamente. Sendo a matéria-prima da cal um calcário puro é composto basicamente de $\mathrm{CaCO}$, que ao ser queimado para se transformar em $\mathrm{CaO}$ (Cal Viva) perde $\mathrm{CO}$. Esta é, justamente, a fração que reduz de $1 / 3$ a parte perdida. Se a matéria-prima origìnal não é pura ou não foi bem queimada o resultado final sai destes parâmetros.
} 
fica a mão limpa; o mesmo he pondo-a em hum pano limpo de linho se depoys se sacodido torna a ficar limpo; se botando-a em agua e enxauguando-a [sic] não turva a agua, porque turvando-a he indicio de ter mistura de fango, ou poeyra, que faz não endurecer a cal por cuja cauza se fendem e rachão as obras ${ }^{179}$.

A area do mar segundo Leão Baptista Alberto Liv. $2^{\circ}$ Cap $^{\circ} 12$ não he bem empregada em paredes que resguardão o Sul, he melhor porem naquellas que resguardão o Norte: a que for groça e muyto grauda se meterá no groço das muralhas, nos fundamentos e lastros, e não nas abobedas de tijollo, ou entre pedrarias, porque não deycha unir os planos das pedras, ou dos tijollos; e depoys de enxuta a cal ficão no meyo vacuos com que a muralha vem a ficar desligada.

\section{No misturar a cal com a area a que os mestres alveneos} chamão fazer massa, quer Vitruvio Liv. $2^{\circ} \mathrm{Cap}^{\circ} 5^{\circ}$ que sendo a area saybro se metão tres partes delle e huma de cal; se a area for de rio ou do mar se metão duas partes de area e huma de cal, e assim se fará boa massa, e com boa tempera, e pello contrario se se the der mais area do que necessario, pella sua aspereza não fará boa preza, e se se the der menos do que requere ficará como lodo má para se obrar com ella.

Ajuda muyto a firmeza da obra (diz o mesmo Vitruvio) principalmente nos fundamentos, e em lugares humidos o misturar com a cal cacos de louça, pedaços de tijollo e telha ${ }^{180}$, os quais pella sua secura e aspereza enchugão a obra depreça, e a fazem endurecer.

\footnotetext{
${ }^{179}$ Também sobre a areia Vellozo vai buscar os conhecimentos de Vitrúvio, no Livro II, e de tratadistas do Renascimento como Leon Batista Alberti.

${ }^{180}$ A utilização de material cerâmico em pó na argamassa de cal traz propriedades pozolânicas à mistura. Temos alguns estudos no NTPR sobre 0 assunto, nos quais foi comprovado um aumento significativo da resistência mecânica e melhoria de outras propriedades. Encontramos em fortalezas do Período Colonial estas argamassas e aqui em Salvador, entre outros exemplos, podemos citar os parapeitos das muralhas da Fortaleza do Barbalho e do São Pedro e as plataformas dos canhões do fortinho da Lagartixa ou atual Santo Alberto.
} 
Tambem no traçar a cal com a area se ha de advertir a qualidade da pedra com que se ha de fazer a muralha, porque as pedras muyto secas querem a cal amassada com area do rio que he mais fresca; as pedras que são mais humidas a querem amassada [sic] com area de cava que he mais seca, e enchuga melhor: outras muytas advertencias nesta materia tras Leão Baptista Alberto Liv. $2^{\circ} \mathrm{Cap}^{\circ}$ $10^{\circ}$ a donde se podem ver, se bem melhor se aprenderão vendo obrar os mestres.

A cerca dos tijollos não intento agora dizer o tempo, dispozição, e modo de os obrar, isto se póde ver em Vitruvio no Liv. $2^{\circ}$ Cap. $^{\circ} 3 .^{\circ}$ so direy que são os melhores os que forem de barro mais puro e limpo, que não tenha mistura de area, ou saybro, ou de xechinhos [seixinhos]; e que seja o dito barro ou greda primeyro bem molhado, e muyto bem amassado, e depoys de secos ao vento e sol, sobre tudo sejão muyto bem cozidos, porque os que são de terra ou barro ariento são muyto pezados, e depoys se desfazem com as chuvas.

As muralhas feytas de tijollo são as melhores de todas por não serem sugeytas a grandes ruinas, e porque sendo batidas da artelheria fazem menos estilhaços que as de alvenaria, ou de cantaria; mas são caras: as de pedra e barro pella sua pouca firmeza se devem começar sobre o terreno natural da praça com bons alicerces, e a falta de cal deve ser recompensada com alguma mayor grossura, e tambem com mayor escarpa, em que o barato vem a ser pouco, e as ruinas mais promptas: as de alvenaria de pedra e cal bem feytas se devem preferir as de cantaria. 
Em falta de pedra se fazem muralhas de taypa ${ }^{181}$, são mais baratas, mas de pouca duração, principalmente nas obras descubertas, como são as da fortificação; a sua materia he so terra e esta quanto mais pingue, e grasça tanto melhor, mas não barro ou greda: para sua fabrica se armão huns taypays que são humas cayxas de madeyra como mostra a figura 93 seguradas Est.48 com quatro rolos de páo nos quatro cantos com suas cavilhas para depoys se poderem tirar, e mudar mais para diante; são os ditos taypays ordinariamente de taboas de sete the outo palmos $[1,54 \mathrm{~m}$ até $1,76 \mathrm{~m}]$ de comprido, e dous ou tres [0,44 ou $0,66 \mathrm{~m}]$ de alto: nas muralhas da fortificação he necessario que as duas traveças de sima sejão mais curtas para que a taboa de fora se incline a feyção da escarpa que ha de ter: a terra que se mete nos taypays vay molhada de agua, ou somente humidicida, e logo he muyto bem calcada com massos da feyção que mostra a figura 94 Est. 48

e não conciste a bondade desta obra principalmente mais que em ser batida.

Fazem-se tambem em falta de pedra as muralhas de formigão, a sua materia he terra e cal dentro dos mesmos taypays $^{182}$ como a taypa; a terra para esta obra quanto mais groça, arienta, e com mistura de pedrinhas, e cascalho tanto melhor; deve levar ao menos a terça parte de cal, e se levar ametade, a saber dous sestos de terra e hum de cal será melhor; e que a

\footnotetext{
${ }^{81}$ A descrição que se segue é da clássica taipa de pilão.

${ }^{182}$ Esta é uma afirmação interessante demonstrando que a taipa dita "de formigão" além de conter um solo com gravilhão era estabilizada com cal. Observe-se que, inclusive, a quantidade de cal era enorme - deve levar ao menos a terça parte de cal - muito além das proporções recomendadas atualmente para estabilização. Esta taipa deve ser o que alguns autores chamam de "taipa militar".
} 
cal seja quente, isto he, vinda do forno, e sendo feytas nesta quantidade, e bem batidas em nada sedem as de alvenaria na bondade, e talvez que nem tão pouco no custo.

Supposto temos dito o que parece que bastava para instrucção dos officiays Engenheyros que não hão de fabricar as muralhas com as proprias mãos, com tudo ainda nos parece ser conveniente dizer o modo com que as muralhas se devem obrar, para que bem instruidos nesta pratica senão deyxem enganar dos mestres empreyteyros, que não procurão mais que adiantar a obra seja bem ou mal obrada, e com os seus dividos materiays ${ }^{183}$.

Por quanto a fortaleza da muralha não conciste na muyta grossura fora de prepozito, mas na bondade dos materiays, e que com elles seja a muralha bem obrada, diremos as condições que deve ter conforme a informação dos mesmos mestres alveneos ${ }^{184}$, e por sua mesma lingoajem.

Hu'a parede ou muralha para que seja bem obrada, e como convem deve ter as condições seguintes.[,] a saber[:] será encabeçada, escantilhada, matacoada, lagrimada, e ugualhada: cabeças chamão aquellas pedras que são o governo para fazer cada fiada, e hão de ser postas das mayores, com o melhor leyto para bayxo, e a melhor face para fora, assentada sempre com o plumo na mão pellas partes exteriores, e cada pedra assentada com o camartello, de modo que nenhu'a fique em garrida, ides ${ }^{185}$,

\footnotetext{
${ }^{183}$ Novas referências à falta de lisura dos empreiteiros, que poderiam colocar em situação vexatória alguns engenheiros militares menos avisados ou que, mais raramente, estavam em conluio com eles. Não foram poucas as ocorrências de descaminhos da fazenda real registradas em documentos do Período Colonial, mais uma hábito nefasto que nos acompanha em muito maior escala até os dias atuais.

${ }^{184}$ Mestres de alvenaria.

${ }^{185}$ Deve ser uma corrupção da forma latina id est que significa quer dizer.
} 
tremula, ou pouco segura, porque estar na garrida chamão quando tem algu'a couza de bayxo que a faça bolir ${ }^{186}$.

Cada fiada será escantilhada, quer dizer que será de huma mesma grossura, porque escantilhão chamão a huma medida de páo, ou de cana com a qual se vay tentiando para que a parede em toda a parte seja de hu'a mesma grossura, isto he, da medida do escantilhão, do qual porem se não uza nas muralhas escarpadas, porque era necessario que em cada fiada fosse diverso: servem-se então do instrumento chamado arpa, que descreveremos adiante.

Será matacoada por dentro; matacões chamão a hua'as pedras miudas que enchem os vãos de dentro entre cabeça e cabeça, sem sahirem fora á face; depoys disto será lagrimada por fora com hu'as pedras como cunhas metidas entre as cabeças, e outras mais pequenas que se vão pondo á face para a muralha ficar bem lavrada, e igual com as cabeças: finalmente será ugualhada por sima a cada fiada com humas pedras bayxas e largas, e de bons leytos,

\footnotetext{
${ }^{186}$ Aqui existem algumas expressões interessantes cuja exegese é importante para o entendimento do texto e resgate da memória da antiga terminologia da construção, algumas das quais o nosso autor procura explicar. Destas palavras umas são conhecidas dos construtores mais antigos outras não. Assim vejamos: o termo encabeçada está explicado pelo autor e vem a ser a pedra de início, que deve ser uma pedra de face assentada convenientemente, pois nela é que se fixa a linha para alinhar e aprumar a fiada que se vai levantar. Escantilhada é uma fiada que se faz com o uso de escantilhão que é uma espécie de gabarito para dar inclinações que não são exatamente de $90^{\circ}$; um tipo de escantilhão seria o que se usa para dar talude às muralhas como apresentado no tratado de Castriotto de 1583, reproduzido em nosso trabalho sobre As fortificações de Salvador, p. 157; é o que Vellozo chama de arpa [harpa]. Mas, de maneira geral, pode-se chamar qualquer gabarito que sirva para repetir medida ou pendência. Matacoada seria o preenchimento dos vazios com pedras menores (matacões) para se obter maior compacidade da alvenaria. Lagrimada é uma expressão que não conhecíamos, mas a descrição de Vellozo deixa claro que trata-se do que chamamos de "embrechamento" e neste particular uma das muralhas mais bem embrechadas que conhecemos é a da Fortaleza do Morro de São Paulo, no arquipélago de Tinharé. Ugualhada [igualada] seria o bom acabamento do coroamento da muralha. Camartelo é o martelo clássico do pedreiro, que tem do lado oposto à safra, um acabamento em forma de talhadeira. Ficar em garrida é uma situação da pedra pouco firme, com possibilidade de deslocamento, porque a garrida são roletes ou rodízios para facilitar o deslocamento de pedras pesadas na cantaria.
} 
as quais ugualhas entre pedra e pedra se meterão pello meyo da parede com pedras menores, de modo que acabada de lavrar a fiada fique tão direyta por sima como pellas faces, e se advirta que sempre fiquem desencontradas as juntas das fiadas no que toca ás cabeças grandes; e nesta forma será bem obrada a muralha, não the faltando porem com a boa cal, e mais materiays.

\section{Scholio}

Alem das diversas materias para a fabrica das muralhas que dissemos no capitulo antecedente Fritach, e Dogen liv. 2 pag. 398 descrevem a forma dos sespedes ${ }^{187}$ com que tambem em Flandes se costumão revestir os terraplenos pella parte exterior em lugar de muralha dando a terra daquelle paiz commodidade a se cortarem os ditos sespedes na forma seguinte.[:]

Cortãose huns torrões de terra boa e firme cubertos e misturados de erva e raizes; são ordinariamente de comprimento de dous palmos $[0,44 \mathrm{~m}]$, com hum de largo [0,22m], e 3/4 de palmo [0,165m] de groço, a qual groçura vay diminuindo hum pouco para o cabo a fim de que a terra do reparo se accommode bem e firmemente com elles, e depoys de aparados pellos lados com hu'a pá de ferro cortadeyra se assentão igualmente na obra com erva para baixo, e toda a fiada se cobre com hu'a pouca de terra solta para melhor a igualar; a cada duas fiadas se mete hu'a camada de fachina solta, com a rama desfolhada para dentro, e os tallos para fora, mas com

\footnotetext{
${ }^{187}$ É o termo latino como referido em Vegécio. Trata-se de terra cortada em forma de paralelepípedos, conhecidos, também, vulgarmente como "torrão" nos documentos militares, expressão que é igualmente empregada por Vellozo mais adiante. Em construções civis eram utilizados para paredes de edifícios, porém, sem raízes. Em certos casos foi conhecido também pelo galicismo "gazon" ou "terra gazonada" principalmente quando era com raízes.
} 
tres ou quatro dedos retirados para dentro da fiada exterior, a fim de darem lugar a se aparar esta face com a pá cortadeyra, advertindo que quando se assentar cada fiada, os sespedes ou torrões della hão de cobrir as liações, isto he, as juntas dos outros torrões da fiada debayxo, como se fossem xilhares [silares] de cantaria, e cada sespede deve ser pregado com hu'a estaca pequena delgada de dous palmos $[0,44 \mathrm{~m}]$ de comprido, e que fique bem fincada no terreno do corpo do reparo.

Cada camada de fachina será cuberta de outra camada de terra solta bem socada, e igualada primeyro que se assentem as outras duas fiadas de torrões; e sendo obradas em tempo seco serão estas camadas de terra e fachina auguadas [aguadas]; e se the semeará nellas avea, e semente de grama.

Este he o modo com que se costuma fazer esta obra de torrão nas partes onde a commodidade para se tirarem, o que so he em prados, e terras frescas; porem sem embargo de que com elles se seguem as escarpas facilmente da conta que se querem; diz Dogen pag. 397, e 399 que mostrou a experiencia que nunca se unem bem, nem formão hum so corpo com o reparo, e que como são distintos entre si, e huns mais florentes e vivazes que os outros, a respeyto das ervas e raizes, não podem de tal modo unirse que pellas juntas não fiquem sugeytos ao sol e chuva, e outras inclemencias do tempo, e que por tanto o insigne architecto melitar Mauricio Principe de Orange ensinado da experiencia mandou desfazer em muytas cidades aquella camiza de sespede accomodando em seu lugar outra de terra banhada e bem batida, espalhandose no entremeyo quando se fabricava muyta semente de grama, e unindoa bem com o restante do terrapleno, porque desta maneyra ficava esta camiza sem as juntas dos sespedes pellas quais recebia o danno. 


\section{$\mathrm{Cap}^{\circ} 26$ \\ DO INSTROMENTO CHAMADO ARPA NECESSARIO PARA SE DAREM AS ESCARPAS AOS REPAROS, PARAPEYTOS, E MURALHAS.}

Para fazerem as escarpas uzão os officiays mecanicos de hum instrumento que em Frances se chama Harpe [itálico nosso] pella semelhança que tem com a harpa instromento muzico, e porque a sua discripção pertence aos Architectos melitares a descrevem na forma seguinte.[:]

Consta (segundo Fritach liv. $1^{\circ} \mathrm{Cap}^{\circ}$ 9) de hu'a taboa trianFig. 95 Est. 48 gular como DBH cortada em esquadria com o angulo B recto, cuja altura BD sera de quatro palmos $[0,88 \mathrm{~m}]$, a largura $\mathrm{BH}$ será conforme a proporção que se quizer tenha a baze ou talud da escarpa a respeyto da altura do reparo, ou muralha, como se se houver de dar a baze como ametade da altura será o lado $\mathrm{BH}$ de dous palmos $[0,44 \mathrm{~m}]$, que he ametade da altura DB.

Se houver de ser ao quinto como costumamos dar nas muralhas de pedra e cal se fara o dito lado $\mathrm{BH}$ de $4 / 5$ de palmo [0,175m] que vem a ser a quinta parte da dita altura $\mathrm{BD}$; ou se fará de hum palmo $[0,22 \mathrm{~m}]$ se se quizer a escarpa ao quarto, que he a cada quatro palmos $[0,88 \mathrm{~m}]$ de altura hum de talud, e semelhantemente segundo qualquer outra proporção.

A dita taboa triangular será de huma polegada ${ }^{188}$ de groço, e se encayxará segundo o comprimento da hypotenuza HD da regoa IK que será de dous dedos de groço, e larga 3/4 de palmo [0,165m] ou mais, e os seos extremos I, K serão cubertos com chapas de

\footnotetext{
${ }^{188}$ Não se trata da polegada inglesa, mas um valor aproximado que corresponde a $1 / 8$ do palmo, ou seja, 0,0275 , enquanto a polegada inglesa vale $0,0254 \mathrm{~m}$.
} 
ferro, para evitar que se não fendão com o seo uzo: distante do lado $\mathrm{BD}$ couza de $3 / 4$ de palmo [0.165m] se tirará hu'a linha parallela a elle, de dous athe dous palmos e meyo [0,44m até $0,55 \mathrm{~m}]$ de comprido, no fim da qual se fará o buraco X para receber o plumo CX, mediante o qual se conhecerá quando o instrumento está posto a perpendiculo, como se requere, aplicandose ao reparo, ou muralha, para segundo a inclinação da regoa IK se hir obrando a escarpa, e para que o plumo CX se não desvie muyto do buraco $\mathrm{X}$ para hu'a ou outra parte se the accommoda no meyo anel L, que o detenha; finalmente se lhe poem a argola $\mathrm{G}$ a qual serve para com hu'a mão se pegar no instrumento, e com a outra pella fenda $\mathrm{F}$, que se the fará parallela com o lado BD.

Desta maneyra descreve Fritach a harpa; a mesma descripção tresladarão Dogen Cap. ${ }^{\circ}$ ultimo, e Goldman liv. $2^{\circ}$ propozição 24 , excepto que a fazem mais pequena, querendo que o lado $\mathrm{BD}$ seja só de palmo e meyo [0,33m], ou ao mais de tres [0,66m], e BH respectivamente ao talud que se pertende, ficando melhor nesta forma pela facilidade de se mover.

Porem posto que se faça mais pequena ainda assim he de muyta fabrica; mais facilmente obrão os nossos officiays, os quais fazem duas regoas de ferro, que unem de modo que ellas formem a Est. 48 escarpa que querem como se ve na figura 96 então unindo ou assentando a regoa $\mathrm{AB}$ sobre a muralha, a outra regoa $\mathrm{AH}$ the mostra logo a escarpa que hão de hir seguindo, e esta deligencia fazem para assentar as mestras em cada fiada, e tambem lhe serve este instrumento para lavrarem as pedras para os cunhays, formando com o angulo menor GAB o leyto da pedra, e com o outro BAH o sobreleyto, ou como elles chamão com lingoagem barbara, tiranteza, e badanteza, a saber ao angulo do leyto que sempre he 
agudo chamão tirante, e ao angulo do sobreleyto que he obtuzo, e formão ambos sempre o valor de dous rectos chamão badante.

Ha tambem outra sorte de harpa, que serve para examinar a escarpa de todo o reparo ja feyto, e por esta cauza se chama sensoria

Est.49 tendo a principio nome de Sambuca munitoria; he na forma q' parece na figura 97 Dogen liv. 2 Cap. ${ }^{\circ}$ ultimo a descreve na forma seguinte: diz que a taboa KIPQ será de largura de hum pé ou palmo e meyo $[0,33 \mathrm{~m}]$, e de comprido quatro pés ou seis palmos [1,32m], a grossura de hum dedo; sobre ella assentará outra do comprimento que quizerem posta em esquadria, na qual se porá o perpendiculo MN que jogue livremente em hum buraco feyto para este effeyto na dita taboa perpendicular, ao pé da qual se pregará hu'a traveça para melhor a segurar que se não desvie da esquadria, e nella se uma outra triangular ORZ, da qual continua hu'a regoa que alcanse muyta parte da altura do reparo, e com tal inclinação qual houver de ser a da escarpa:

A dita regoa OX deve ser repartida em partes iguais respondentes aos pés da linha $\mathrm{OR}$ em q' estão signalados quatro pés $[1,32 \mathrm{~m}]$, e outras tantas partes the ficarão respondendo na linha OZ porem mayores por ser OZ hypotenuza do triangulo rectangulo OZR, e por tanto cada hu'a das partes de OZ será mayor que cada hu'a das de OR; e o restante da regoa ZX se repartirá tambem em partes iguais como as de OZ.

O seu uso he que havendose de examinar a escarpa de algum reparo se deve accommodar a linha IK com a da raiz da muralha, e a regoa com a declevidade encostará pella muralha asima, e se se ajustar ficando o perpendiculo em seu lugar se entenderá estar bem feyta a escarpa; mas se a dita regoa se não ajustar com ella não estará bem feyta, e necessitará que se lhe emmende a falta que tiver. Serve o mesmo exame para ver se está bem feyta a declividade do fosso. 
E sendo cazo que a regoa não possa ser tão grande que avance toda a altura do reparo ou muralha, se examinará a sua escarpa athe onde ella chegar, e depoys se continuará dali para sima, e juntamente se conhecerá a quanta altura tem subido o reparo, porque ajustada a regoa OX com a escarpa, a dita regoa mostrará os pés da altura perpendicular a que tem subido, que por isso se fazem mayores na regoa proporcionalmente para que mostrem a verdade na altura da linha perpendicular.

Nas muralhas que são feytas de torrão o melhor modo de conduzir direytas as suas escarpas he fincar na linha fundamental exterior de cada lanço da fortificação duas ou mais regoas de madeyra bem direytas, e de comprimento bastante inclinadas na proporção que se tiver assentado ha de ter a escarpa, as quais regoas se borneem [sic] bem, e se segurem com outras varas que a sostenhão e subjuguem para que não desmintão, e por ellas se cordea, e se aparão as fiadas para que a obra va liza e igual ${ }^{189}$.

\section{$\operatorname{Cap}^{\circ} 27^{\circ}$ \\ DO MODO COM QUE SE DEVEM OBRAR OS TERRAPLENOS.}

Tendo dito athe aqui a forma com que se devem fabricar as muralhas, e da escolha que se deve fazer dos materiays, seguese finalmente dizer o modo com que se devem obrar os terraplenos na fabrica dos quais se deve ter hu'a grande concideração, porque de serem bem obrados, e com as circunstancias necessarias pende [depende] a sua conservação, quando não forem revestidos de mura-

\footnotetext{
${ }^{189}$ É o mesmo processo que ainda de usa para guiar a construção de um muro com "arrasto".
} 
lhas, e se o forem pende [depende] a conservação destas; que podem ser arruinadas pella má dispozição dos terraplenos, ou sendo-o aquellas pella bateria inimiga, se arruinarão estes tambem se não tiverem tal união que per si so se possão sustentar, e sempre a fortificação deve ser por tal modo obrado, com que sem muralhas se pudesse sustentar, e nem sempre ha commodidade e cabedal para se fazerem muralhas de pedra, e he necessario valer da fortificação so de terra, por ser materia que em toda a parte se acha; pello que diremos as conciderações com que devem ser feytos neste cazo, porque de serem bem obrados pende [depende] a sua conservação.

Para isto se deve primeyro dar noticia das varias qualidades de terra de que largamente fazem menção alguns auctores, e segundo refere o insigne Architecto Vicencio Scamozi ${ }^{190}$ liv. $7 .{ }^{\circ}$ parte

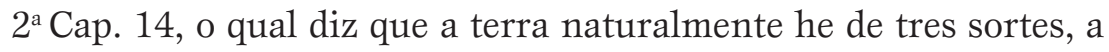
saber saybro, argila (que he o mesmo que greda ou barro) e terra ordinaria, que he a lavradia, e ainda desta diz que ha varias castas, porque ou he pingue e tenaz, ou magra e solta, arenoza, ou oliginoza; por oliginoza se entende aquella que tem huma certa humidade natural que sempre retem em si, differindo nisto da humida, porque esta com o tempo seca, e aquella nunca larga a humidade em mais ou menos graos.

Aquella terra que he magra e solta, ou arenoza não he boa para os parapeytos, nem he a melhor para os terraplenos, por não constituir corpo tenaz, que per si só se possa sustentar sem arrimo de muralhas fortes, ou algum outro sustentaculo e ajuda; e quando por pura necessidade se haja de uzar della quer Pedro Sardi na

\footnotetext{
${ }^{190}$ Observar que o autor conhecia até o tratado renscentista menos divulgado de Vincenzo Scamozzi (L'ideia della architettura universale) e que a suas citações são pormenorizadas de quem conhece a fonte principal e não como se vê amiúde referências de um texto célebre apud fulano e beltrano.
} 
Corona pagina 249, e 250 se meta na obra muyto bem banhada, e misturada com palha, ou feno mediocremente trilhado, e depoys com vimes e vergas de salgueyro, e outras varas sutiys de fachina de hum dedo ou pouco mais de groço, postas ás camadas como diz Delichio $^{191}$ pag. 87 , a saber fazendo huma cama de terra de meyo palmo $[0,11 \mathrm{~m}]$ de alto, a qual sendo muyto bem banhada se baterá muyto bem com os pizões, ou pilões (como aqui são chamados) depoys outra cama de fachinha sutil esfolhada que fiquem so as varas, sobre a qual hirá outra de terra como a primeyra banhada e batida, e assim sucessivamente se hirá continuando, e fazendo o terrapleno athe toda sua altura.

Como neste paiz em que escrevemos não ha vimes, nem vergas de salgueyro, se poderá em lugar destas usar de sipós de que he muyto abundante, e outras vergontas que não faltão de boa qualidade.

Podese tambem como diz Delichio pagina 89 misturar com esta terra solta ou arenoza esterco de cavalos, ou outras materias groças e podridas (como bagaceyra de engenho) ${ }^{192}$ que a fação unir, e as camas de fachina de quando em quando atraveçadas humas sobre outras, intrepondo-se todavia sempre cama de terra entre huma e outra fachina.

Do mesmo modo se obrará quando a terra for saybro, mas no que toca ás camas se podem fazer de palmo e meyo [0,33m] de alto athe dous palmos $[0,44 \mathrm{~m}]$, sem embargo de Pedro Sardi as fazer so de

\footnotetext{
${ }^{191}$ Deve tratar-se de referência ao tratadista alemão Wilhelm Dilich que viveu entre 1571 e 1655. O seu texto mais conhecido é Peribologia oder Bericht von Vestungs gebauen, editado em 1640 e dedicado ao Duque da Saxônia.

${ }^{192}$ É interessantísimo a demonstração da experiência acumulada por Vellozo de Brasil, especialmente em Pernambuco onde viveu e morreu, utilizando-se do abundante rejeito do bagaço de cana, para fazer faxina dos terraplenos, o que, diga-se de passagem, deve funcionar muito bem.
} 
meyo palmo $[0,11 \mathrm{~m}]$, e em sima do terrapleno, em as superficies que ficão expostas ao sol se deve procurar assentar alguma camada de melhor terra, e nella semear semente de grama, e não se achando esta, se uza da mesma grama verde cortada em pedaços, a qual se hirá regando por alguns dias athe que pegue, e outras mais ervas que pegão e crião raizes, unindo a terra; mas a grama se regula ser a melhor fazendo bom effeyto em defender o terrapleno de ser gastado das aguas da chuva: o mesmo se deve fazer nas camadas intermedias de terra, onde tambem se hirá lançando sevada, e avea para que rebentando fortifique o terrapleno como se faz em Flandes.

O barro he na qualidade contrario a terra arenoza e solta, como tambem ao saybro, e por ser terra graça ${ }^{193}$, dura, e viscoza, não he tão boa para os terraplenos, porque no tempo do estio abre grandes fendas, que embebendo depoys as aguas da chuva cauzão grande danno nas muralhas, e no tempo da obra se está seco rezulta o dito inconveniente, e se molhado quando se quer bater com os pizões, e calcar com os pés cauza grande trabalho pella demaziada viscozidade com que pega, sem que isso deyxe depoys de seco de abrir nos estio as fendas sobreditas.

Se de necessidade se houver de usar de barro será bom que se lhe va misturando outra terra se a houver, para assim lhe moderar a demaziada fortaleza, e viscozidade, e he necessario que nas muralhas com que este terrapleno for revestido se fação a espassos alguns buracos ${ }^{194}$ para escoar a agua da chuva que se embeber nas fendas e aberturas, que sempre lhe cauza o estio, posto que o barro seja misturado com outra terra magra, por ser tal a sua fortaleza que sempre mais ou menos se abrirá, segundo for misturado com

\footnotetext{
${ }^{193}$ No sentido que usamos de "gorda".

${ }^{194}$ Aquilo que chamamos atualmente de "agulheiros" das alvenarias de arrimo.
} 
mais ou menos terra, ou saybro, se bem sempre pellos buracos da muralha sahirá alguma desta terra ${ }^{195}$ com que fará algum abatimento nos terraplenos, e será necessario que de novo se reformem, e se the tapem as rachaduras.

A melhor terra he a lavradria [sic] não muyto forte, nem magra assim para os terraplenos, como para os sestões, sestos, e sacos para as trincheyras, de que em outro lugar se ha de tratar, porque a dita terra sendo banhada bastantemente, e bem batida se sustenta de per si sem cahir como a magra, nem abrir fendas como o barro.

E com tudo posto que o terrapleno seja de terra boa não se hirá fazendo tomultuariamente so por enchimento, mas hirseha [ir-se-á] lançando ás camadas, e batendo-a que será o melhor, ou ao menos esperar que com os pés dos serventes, e com a conducção dos carrinhos ella se abata, e calque. Pedro Sardi na Corona pagina 250 quer que as ditas camadas se fação de tres quartos de palmo $[0,165 \mathrm{~m}]$ de altura, e que banhando-a moderadamente se bata tanto que bayxe ametade: porem não he necessario que sejão de tão pouca altura; nem deyxará de ser muyto difficultozo bater tanto a terra que diminua a metade de sua altura; e assim se deve seguir o que dizem Fritach liv. $1^{\circ} \mathrm{Cap}^{\circ} 9^{\circ}$, e Dogen liv. 2 Cap. ultimo, os quais fazem cada camada de hum pe $[0,33 \mathrm{~m}]$ de alto, e dizem que

\section{sendo primeyro a terra aguada se bata tanto que diminua} hum terso, ou hum quarto de sua altura.

E para melhor effeyto se deve a terra purgar como dizem Pedro Sardi na Corona pag. 250, e Lorine pag. 124 espalhandose quando se faz cada camada com hum istrumento que chamão Ensinho, ou Ansinho (como tras Bluteau) que he feyto de hum páo com varios

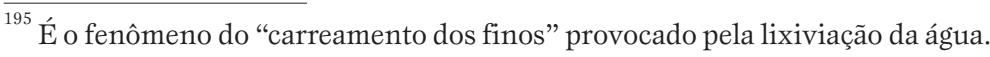


dentes, em o qual prende outro como cabo de enxada, mas mais comprido, e menos groço de que costumão usar os lavradores nas eyras para ajuntar a palha e a separarem do trigo; mas para o effeyto da terra deve ter o dito instrumento os dentes de ferro, e mais miudos, para poderem tirar todas as pedras, ainda que sejão bem miudas, para ficar a terra limpa, porque assim se unirá melhor.

Nas ditas camadas ou lastros de terra se hirão lançando as sementes de grama, de trevo, sevada, e avea, ou outras ervas com naturays em cada paiz que lancem muytas raizes e peguem facilmente; e quando a terra for boa bastara que se lancem camadas de fachina a cada cinco ou seis pés $[1,65 \mathrm{~m}$ ou $1,98 \mathrm{~m}]$ de terra, que na magra he necessario que a cada pé de terra de alto alternativamente se lance hu'a cama de fachina, ou ao menos a cada dous ou tres pés $[0,66 \mathrm{~m}$ ou $0,99 \mathrm{~m}]$ de terra segundo a sua qualidade.

Sendo o terreno de varias qualidades senão deve misturar, mas lançar separado accommodando a melhor casta de terra na parte exterior, e a infima no meyo; e devese advertir que se o terrapleno se fundar sobre terreno brando, ou de terra que ha sido revolvida, necessita de se lhe fazer hum simento [sic] da mesma terra, abrindo para isso hum modo de alicerse como se faz nas muralhas, porem menos fundo: deste modo ficará o reparo tão solido, e rezistira tanto as inclemencias do tempo, que per si so se poderá sustentar, e durar sem o encosto das muralhas.

Sobre o dito reparo depoys de feyto na sobredita forma se lhe plantão alemos, olmos ${ }^{196}$, e outras sortes de arvores agrestes,

\footnotetext{
${ }^{196}$ As árvores citadas são, seguramente, de origem européia. A primeira delas é difícil precisar a família, mas a hipótese mais provável é que seja uma betulácea, que tem variadas espécies. Quanto ao olmos temos mais certeza para afirmar que deve ser a um vegetal da família das ulmáceas, mas não existem elementos seguros para indicar uma das várias espécies possíveis. A hipótese mais provávelé a Ulmus carpinifolia ou Ulmus campestre, que é encontrada em toda a Europa, inclusive em Portugal, considerada pelo autor como árvore agreste.
} 
e que peguem em terrenos secos, o que não so serve de ornato, mas tambem de utilidade para haver lenha que gastar em tempo de sitio, e para fazer carretas sendo necessarias; para com as ramas e troncos junto com terra reparar as brechas, e para impedir a vista ao inimigo, ainda que levante plataformas, ou privarlha de todo estendendose de hu'a a outra arvore alguma tea de pano, ainda que este uzo apontado por Medina Barba no Exame pag. 118 he de pouco momento, porque em quaisquer esteyos, ou estacas fincadas nos terraplenos se podem armar as teas para cobrir a vista do inimigo.

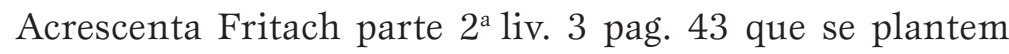
tambem salgueyros ${ }^{197}$ por toda a escarpa interior do reparo, porque servem na necessidade para se repararem as ruinas dos parapeytos, para fazer sestões; e outras obras, e diz que estas utilidades se experimentarão no sitio de Bolduc: em Milão estão cheyos os terraplenos destes salgueyros, e pella parte de dentro ao pé da sobida carreyras de alemos, que se regão com hu'a levada de agua, e servem as ruas entre elles de passeyo onde vão ordinariamente adevertirse todos os senhores e damas da cidade em seos coches.

Antonio de Ville diz que alguns não querem arvores nos terraplenos, porque dandolhe o vento na rama cauzão roido, impedindo que as sentinellas de noute oução e sintão o que vay fora da muralha, mas a isto se responde, que o remedio he deyxalas estar no tempo da paz, e no da guerra cortalas, se mostrarem inconveniente, ou so deceparlhe a rama com [como] diz Fournier Cap. $^{\circ} 13$.

\footnotetext{
${ }^{197}$ Vegetal da família das salicáceas. Em virtude dos usos estipulados por Vellozo deve tratarse da Salix viminalis.
} 
Finalmente se deve advertir que quando se fabricarem os terraplenos se deve deychar aberto o sitio em que houverem de ficar as portas e serventias, como tambem hirem-se logo obrando os canos para vazão das aguas para fora da praça nas partes convenientes, por não ser depoys necessario abrir de novo o terrapleno para este effeyto.

A terra para os parapeytos se não deve admitir senão da melhor qualidade, por serem os que ficão mais expostos, e que o inimigo costuma bater primeyro que tudo, para tirar as defenças. Deve ser esta terra não so purgada como a dos terraplenos, mas sirandada [cirandada] ${ }^{198}$; de sorte que fique bem limpa e apurada; devesse fazer a face exterior do parapeyto de taypa ou formigão, de grossura de dous ou tres pés [0,66m ou $0,99 \mathrm{~m}]$, com sua escarpa como temos dito, e por detras desta primeyra camiza se vay então botando a terra as camadas (como se fes nos terraplenos) de hum pé $[0,33 \mathrm{~m}]$ de groço e se devem socar athe ficarem em hum palmo; se quizerem bem the poderão meter no meyo de sua altura hu'a cama de fachina não muyto groça, com as circunstancias ja ditas nas dos terraplenos.

As banquetas sejão hu'a, duas, ou mais, tambem devem ser revestidas de formigão, porque se forem so de terra, ainda que esta seja muyto batida e socada, sempre a continuação do sobir e decer dos soldados as ha de dannificar.

Restava finalmente tratar da ordem das ruas, dispozição dos edificios, praças e mais partes interiores da fortaleza quando se haja de edificar alguma de novo em paiz despovoado, como póde suceder em alguma destas nossas conquistas; ou quando seja ja a

\footnotetext{
${ }^{198}$ Maneira antiga de dizer "peneirada".
} 
terra povoada restava a forma dos quarteys para os soldados, dos armazens para as armas, e para a polvora, dos payois para os mantimentos, hospitays, e mais ofecinas necessarias á conservação e commodo da guarnição melitar, mas como disto se trata no nosso

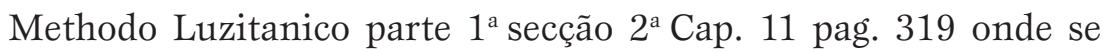
póde ver, nos aqui damos fim a esta segunda parte orthografica.

Fim da segunda parte.

3 
Estampas 


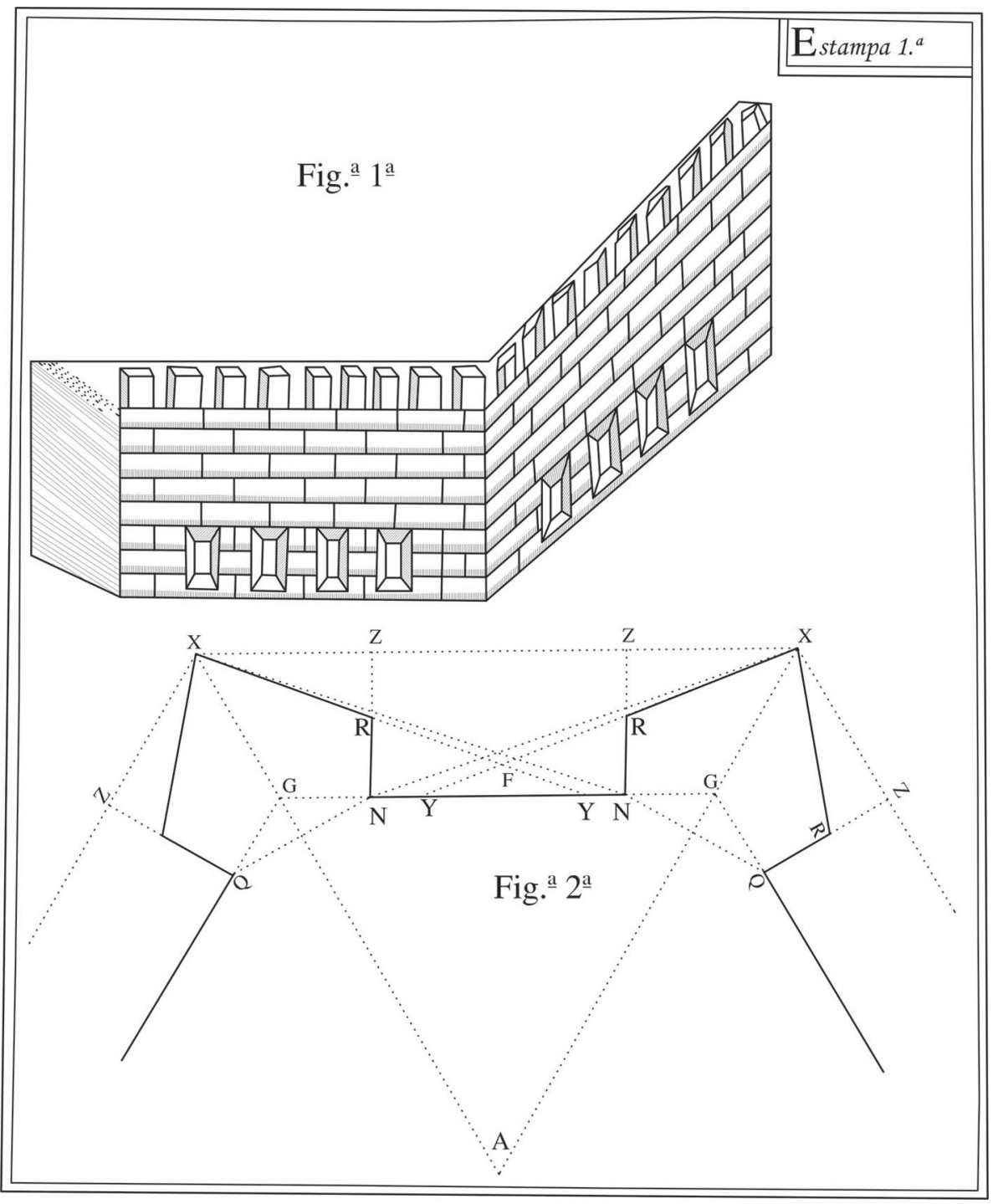




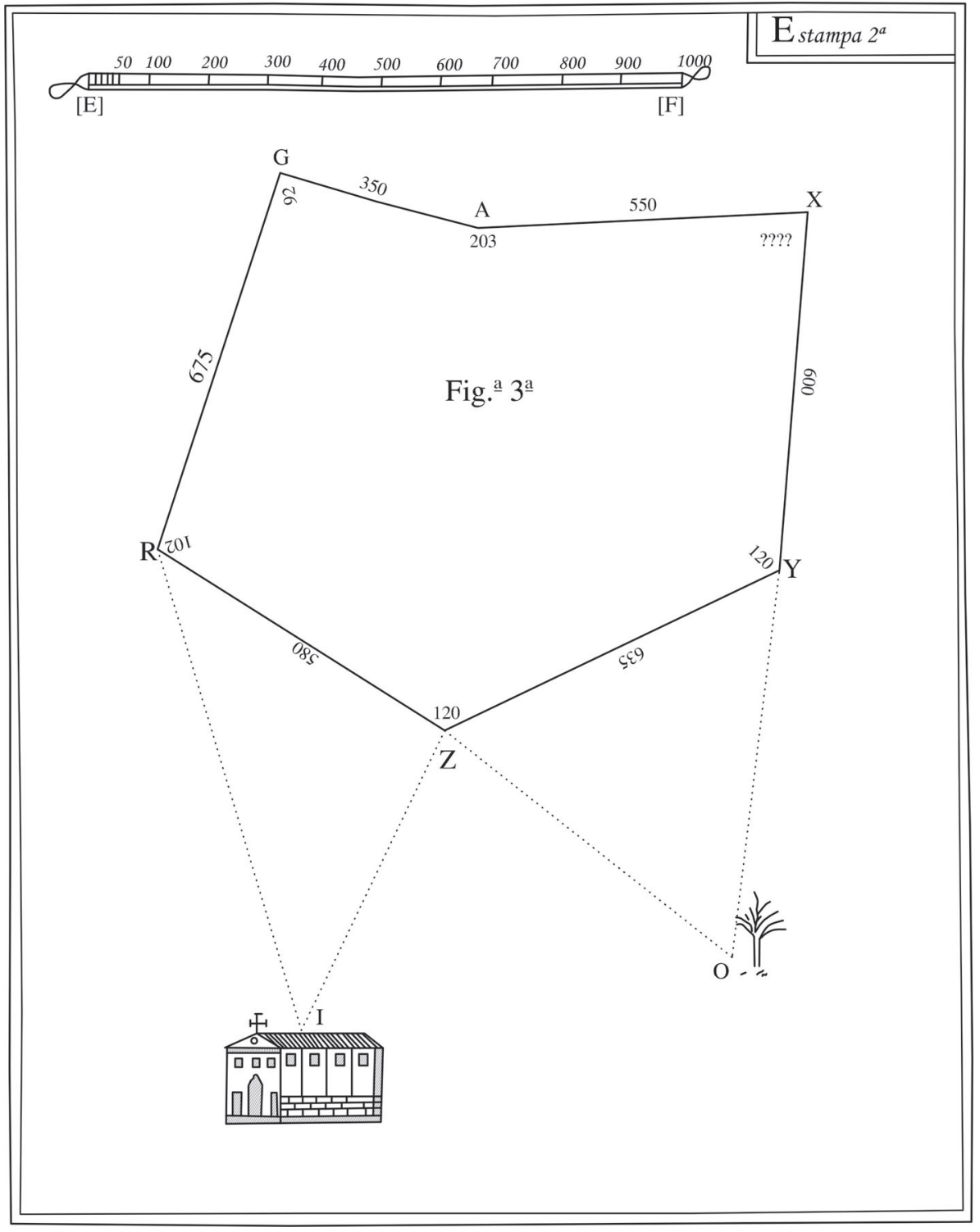




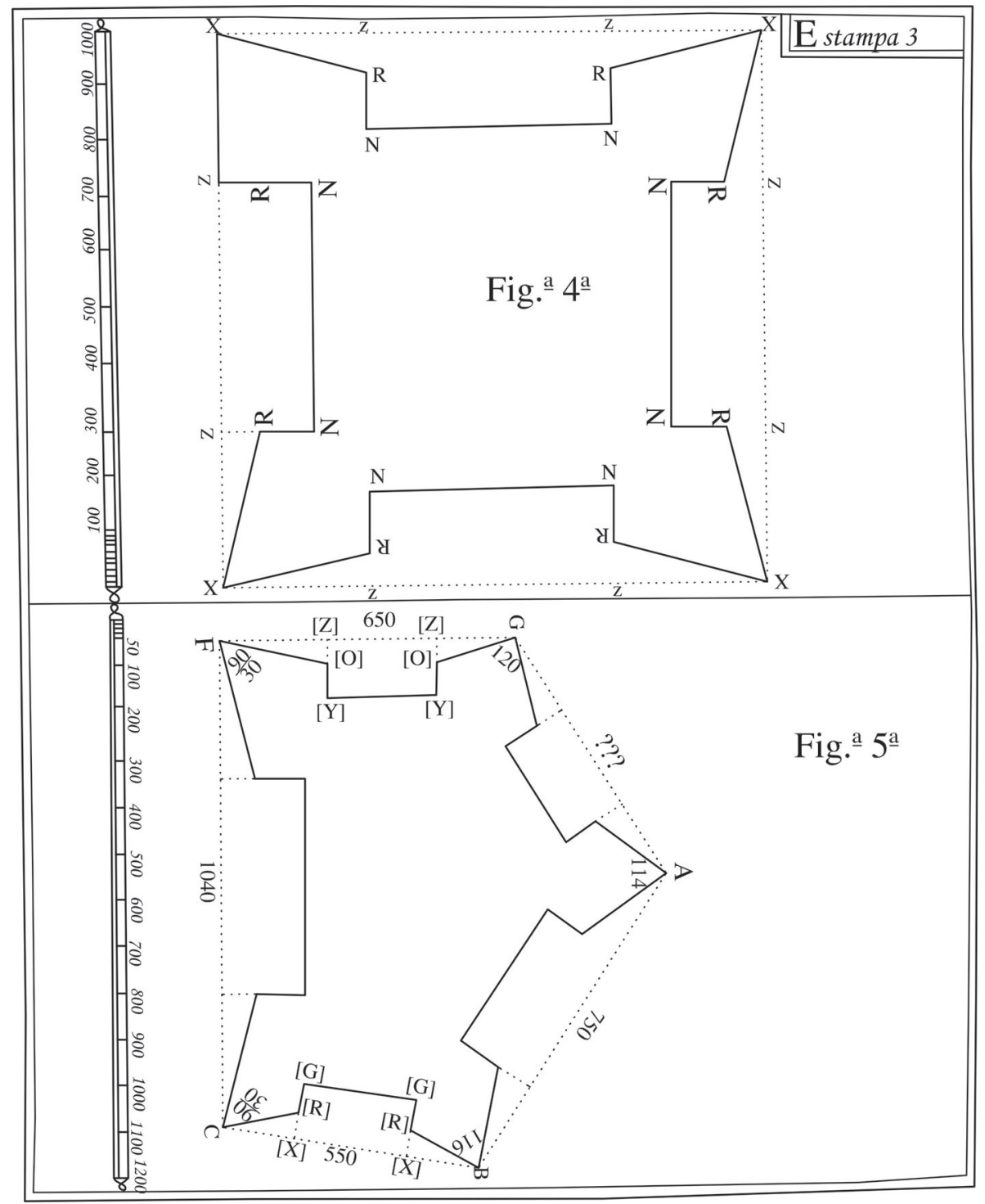




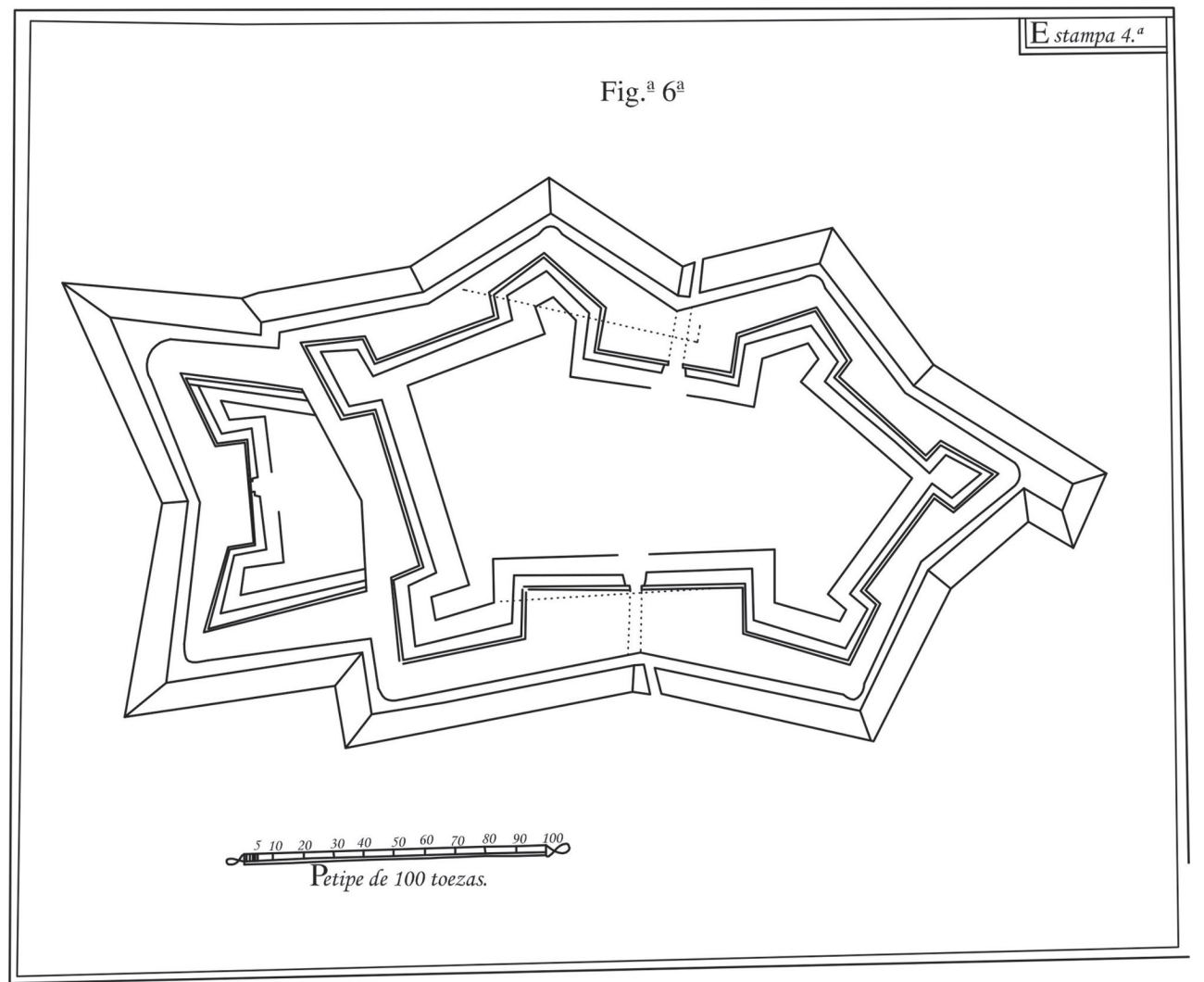




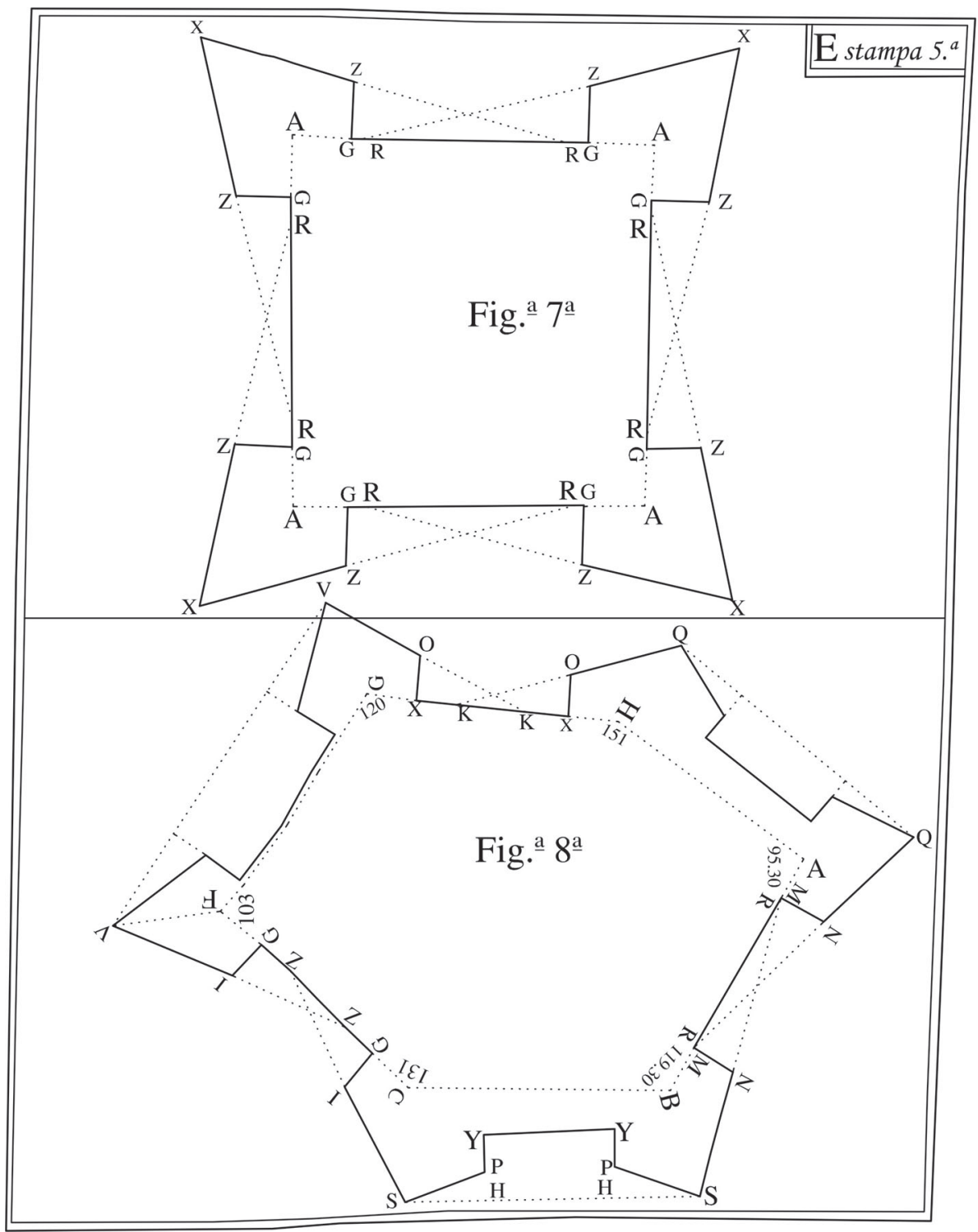




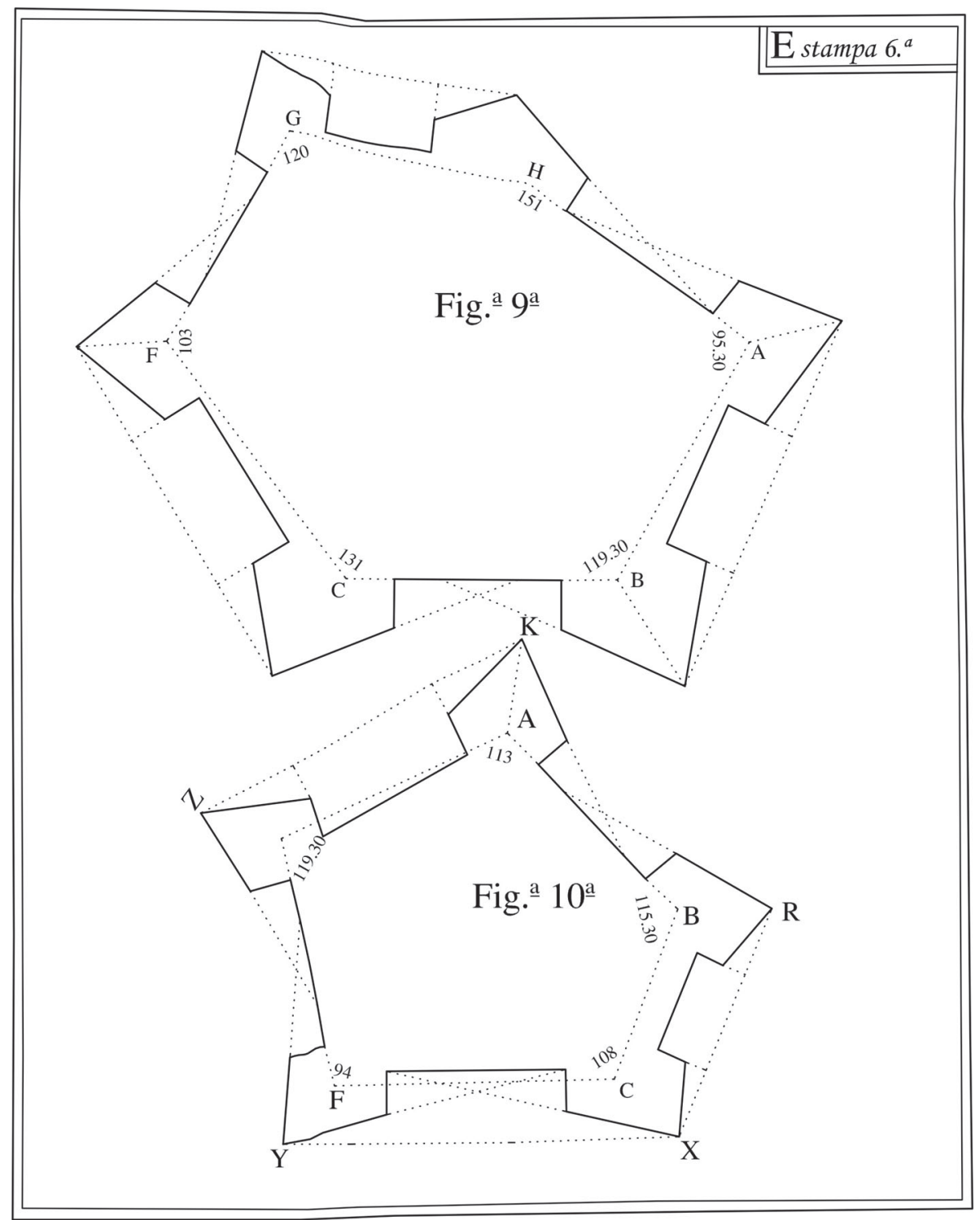




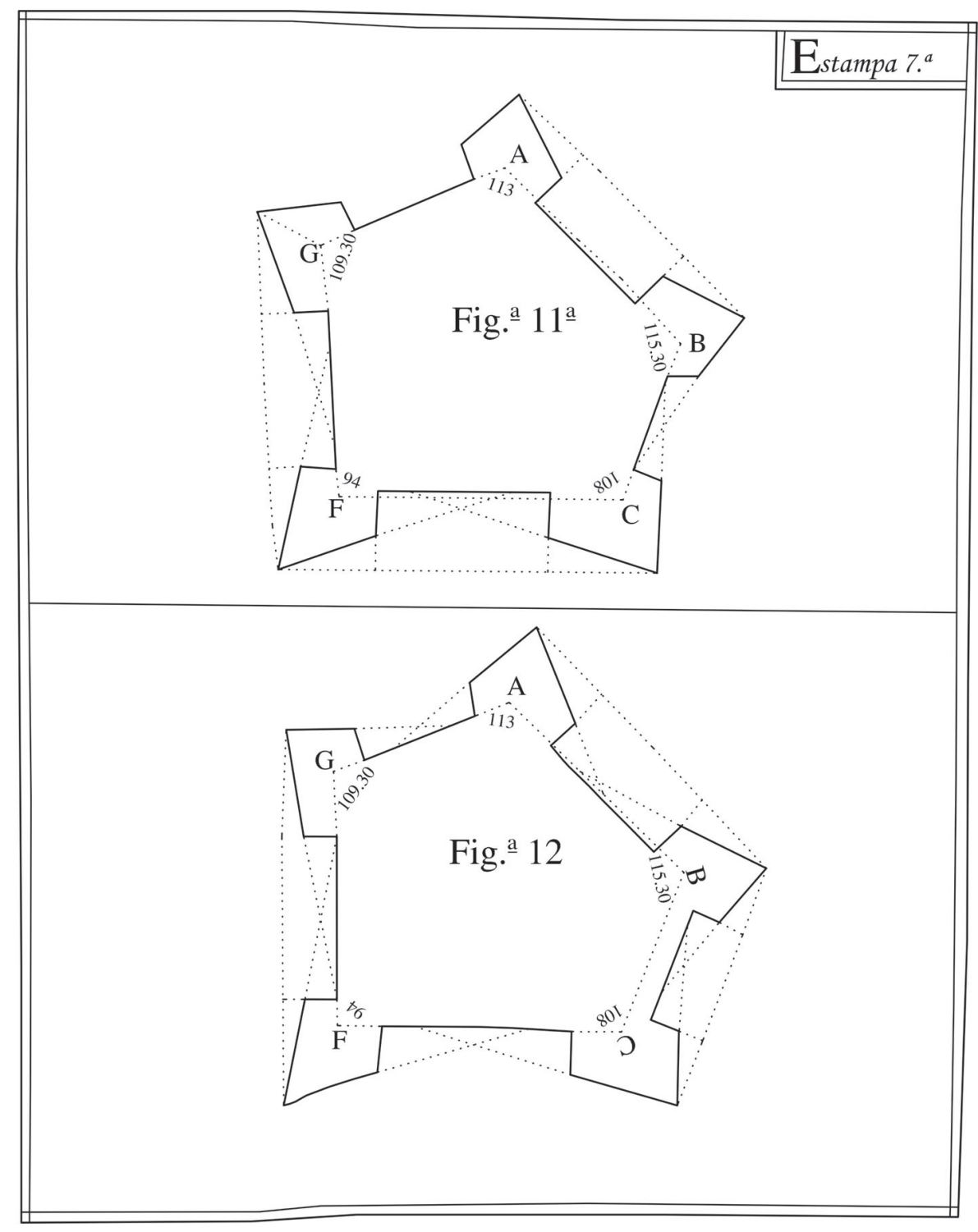




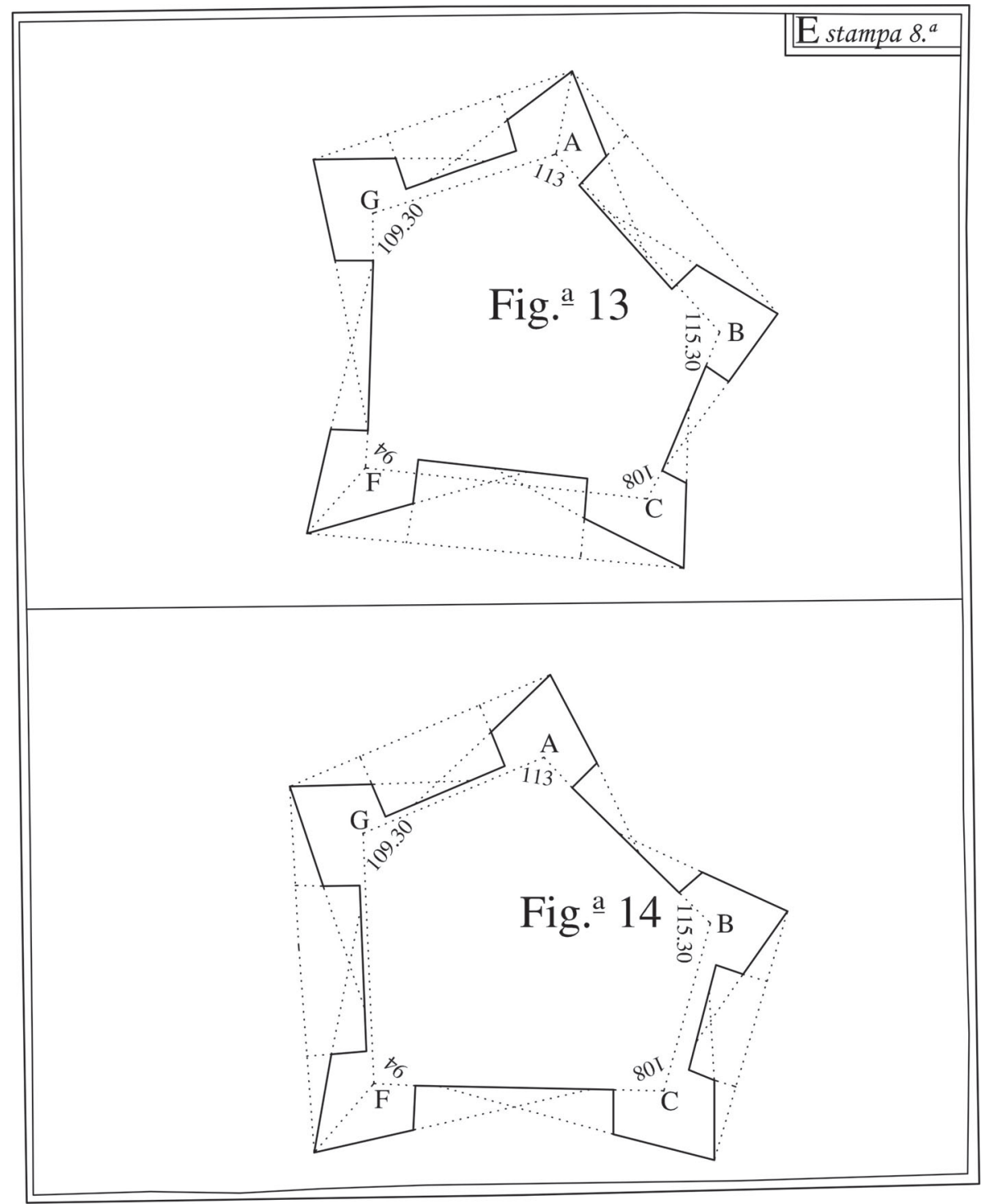




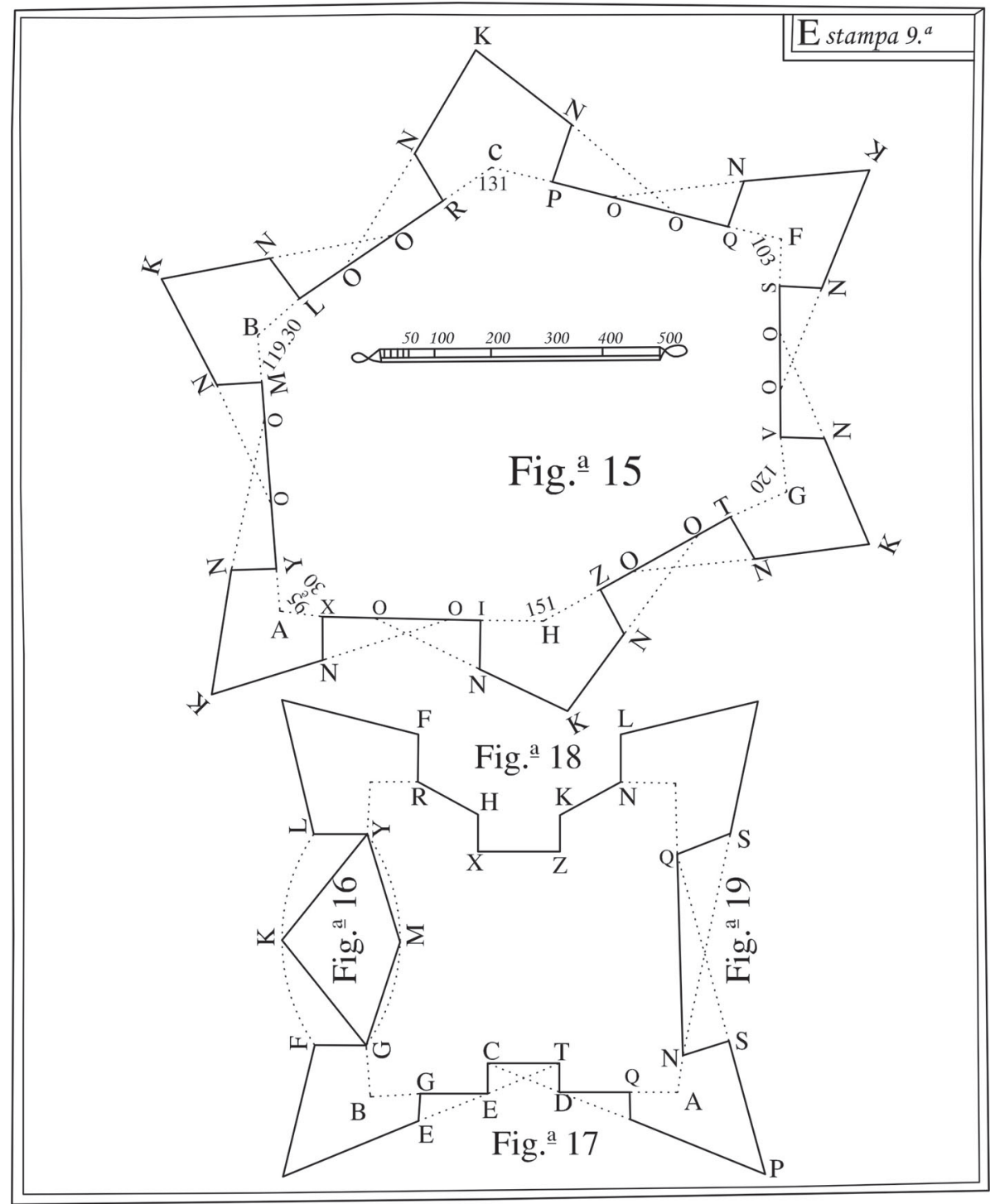




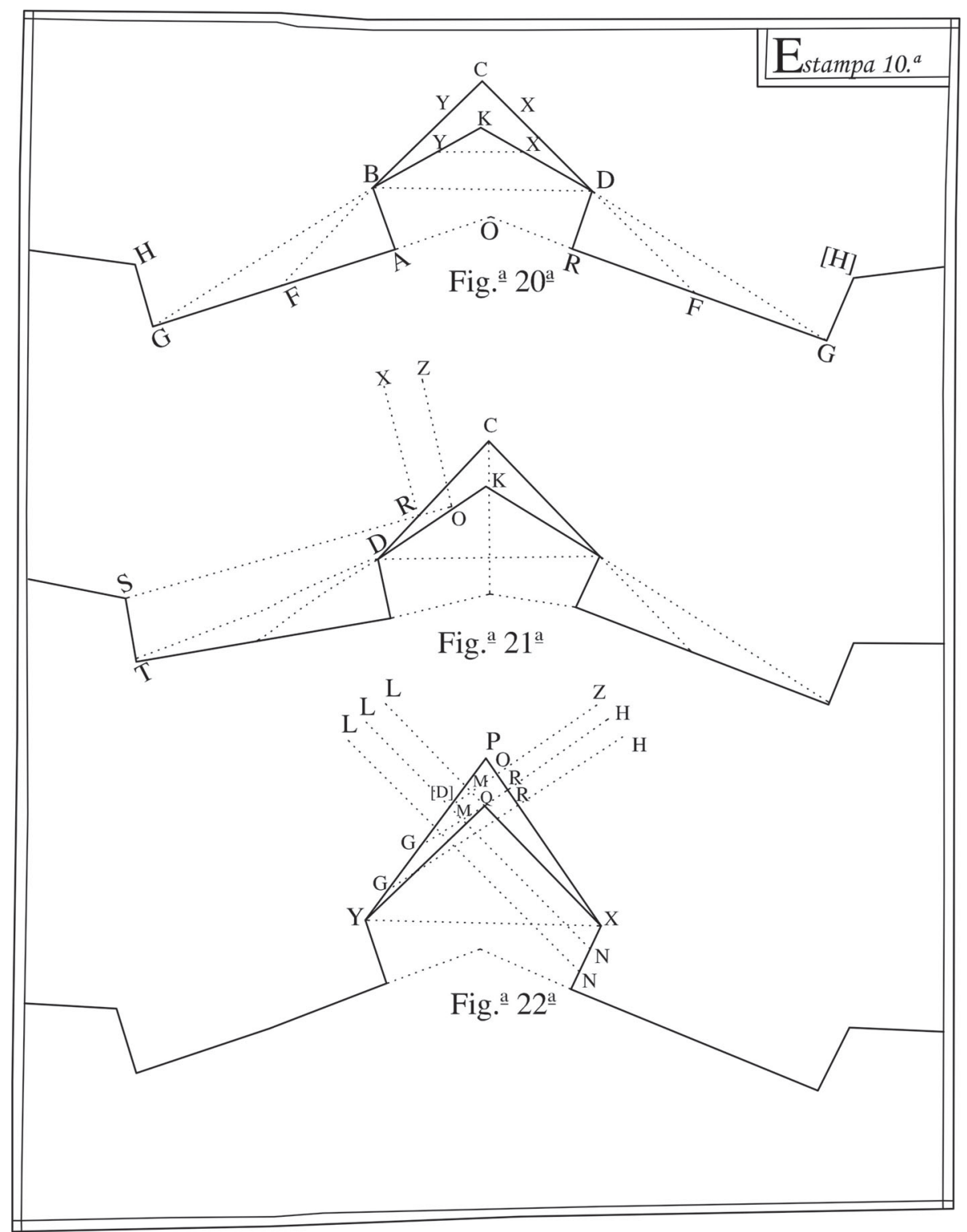




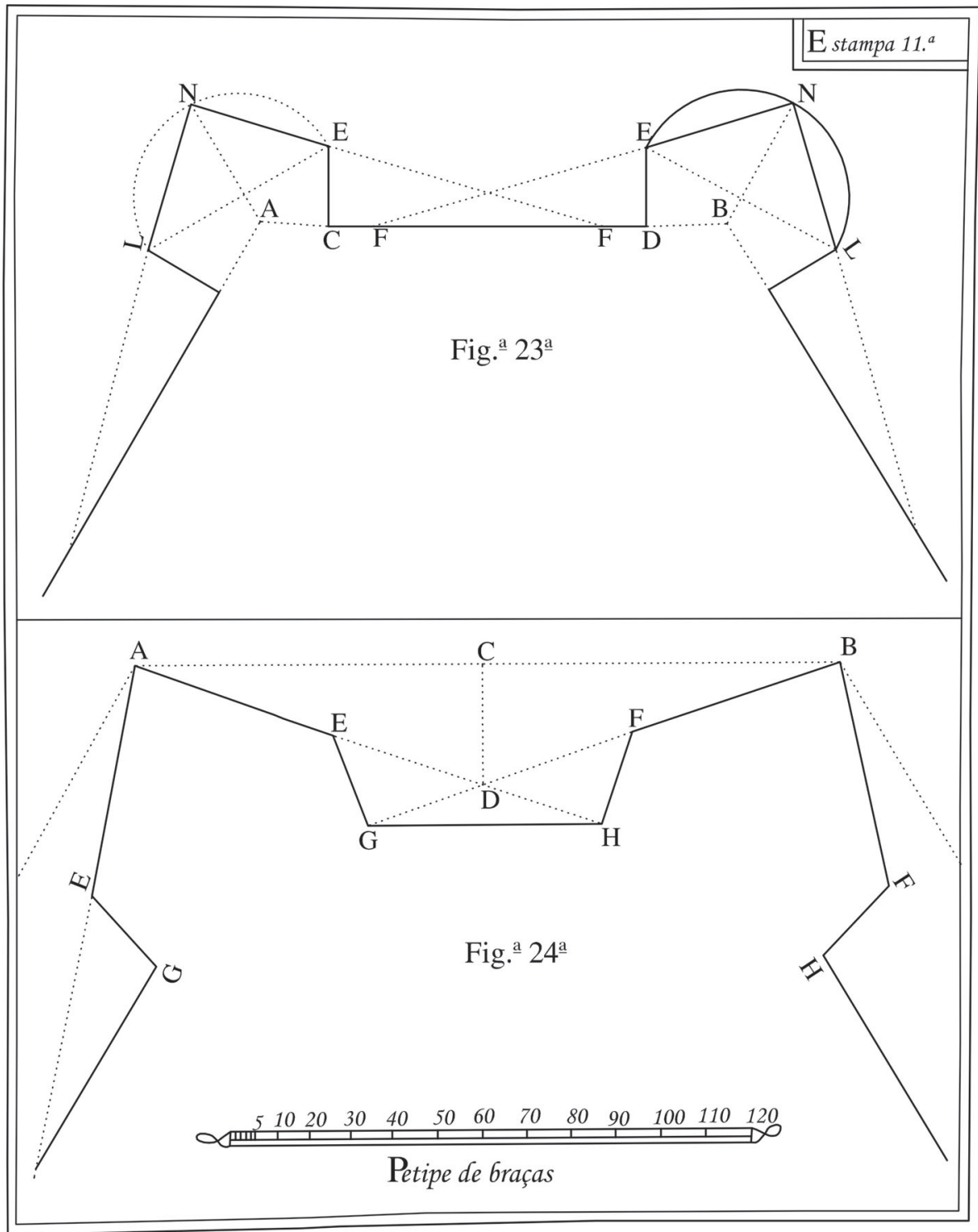




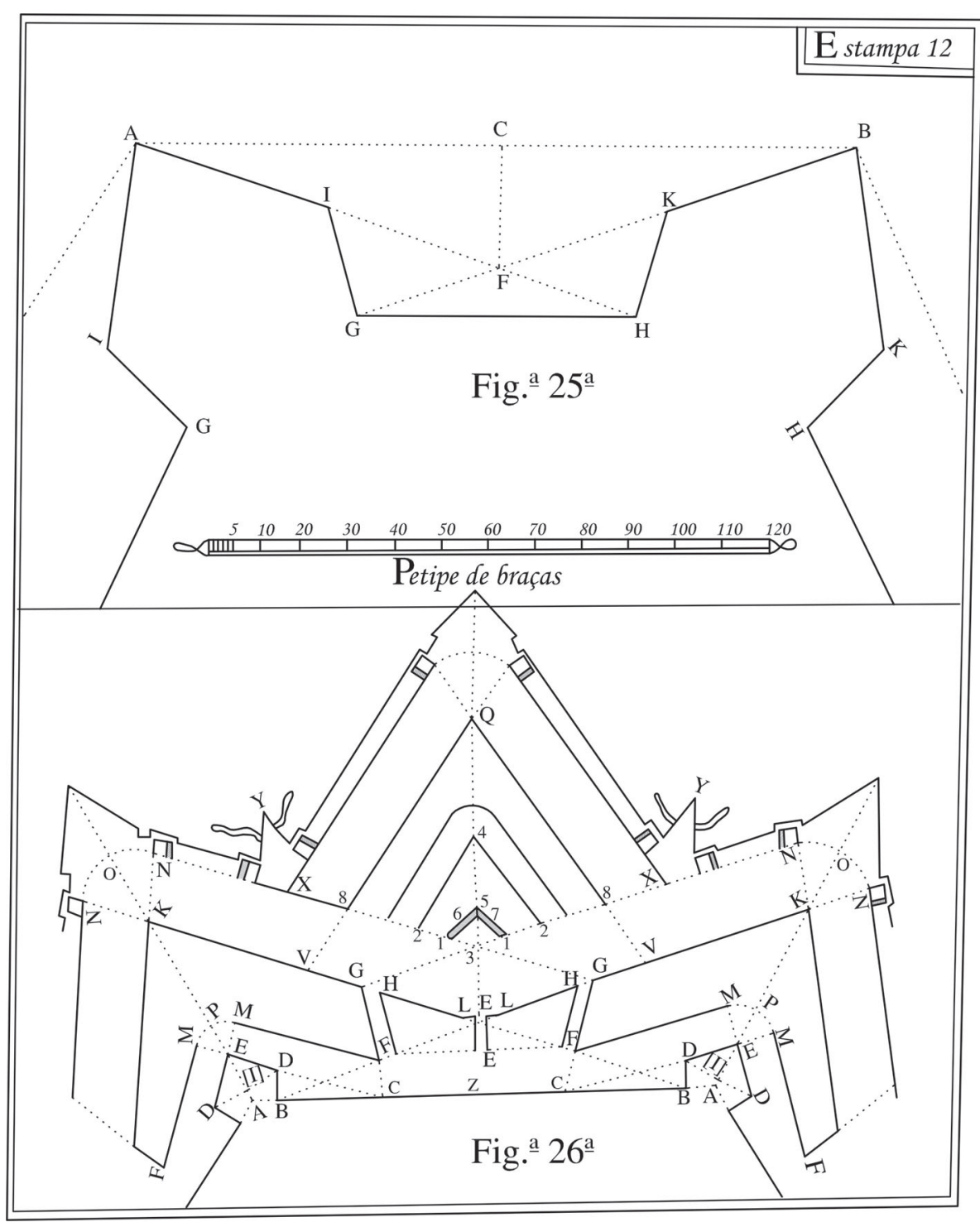




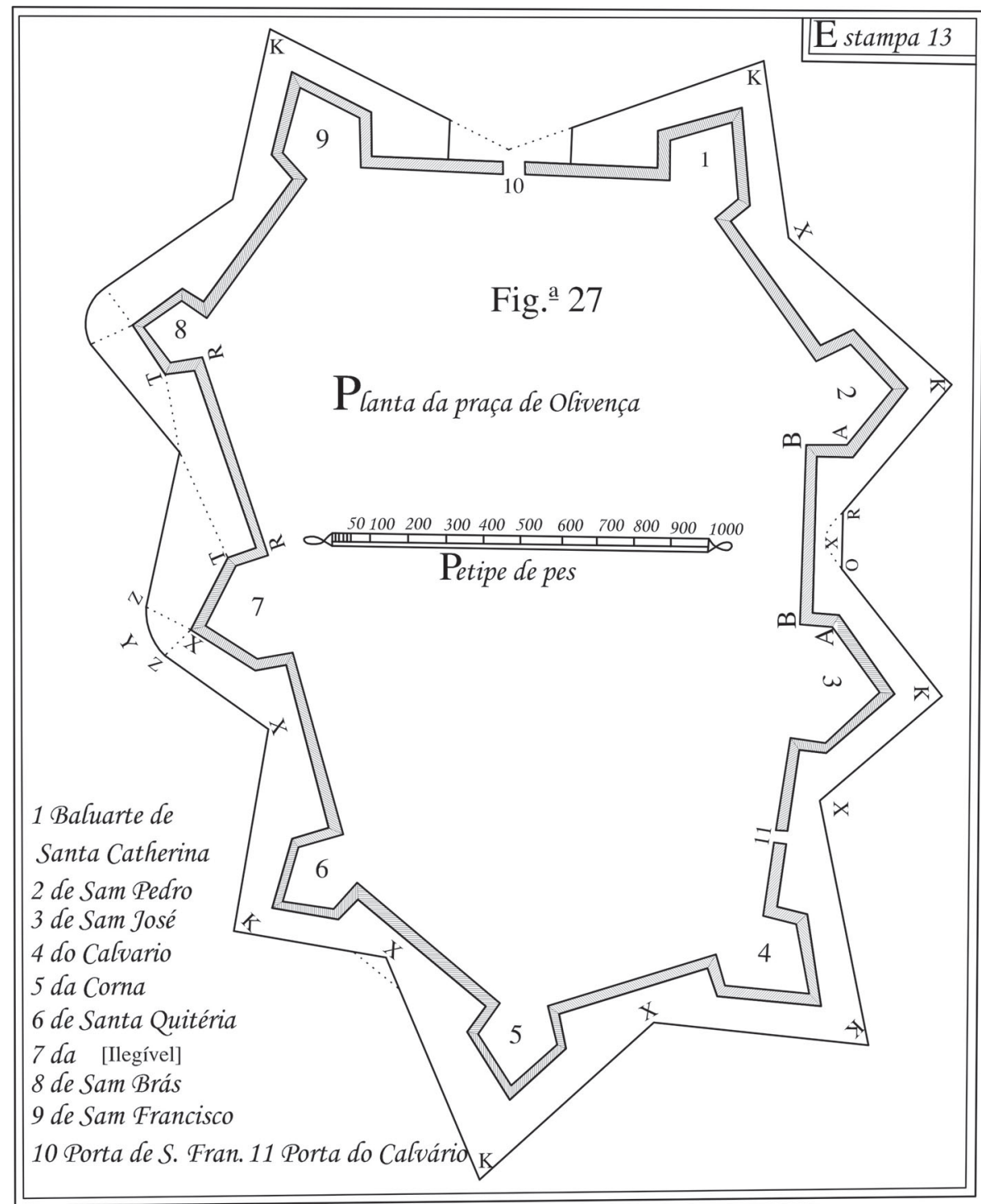




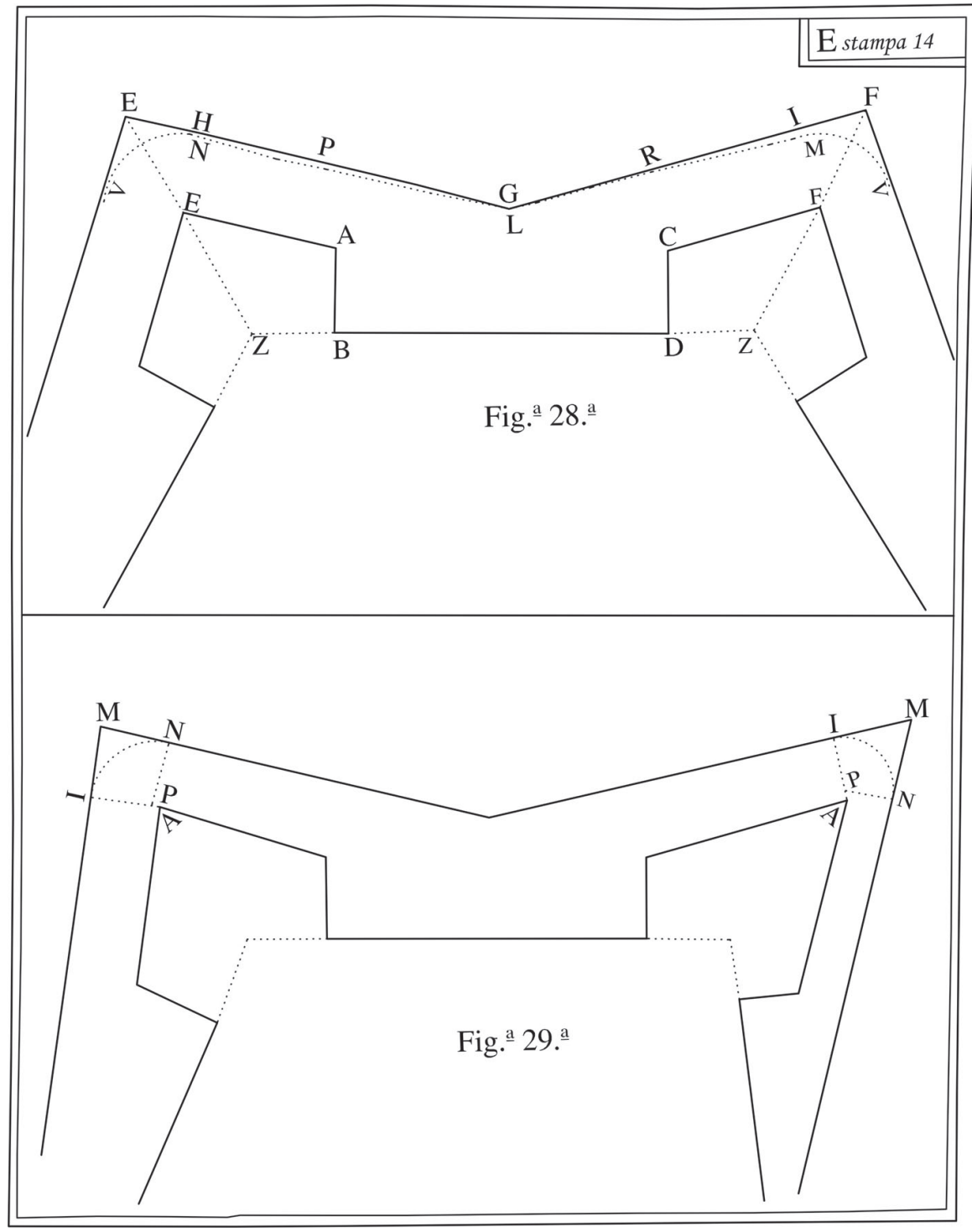




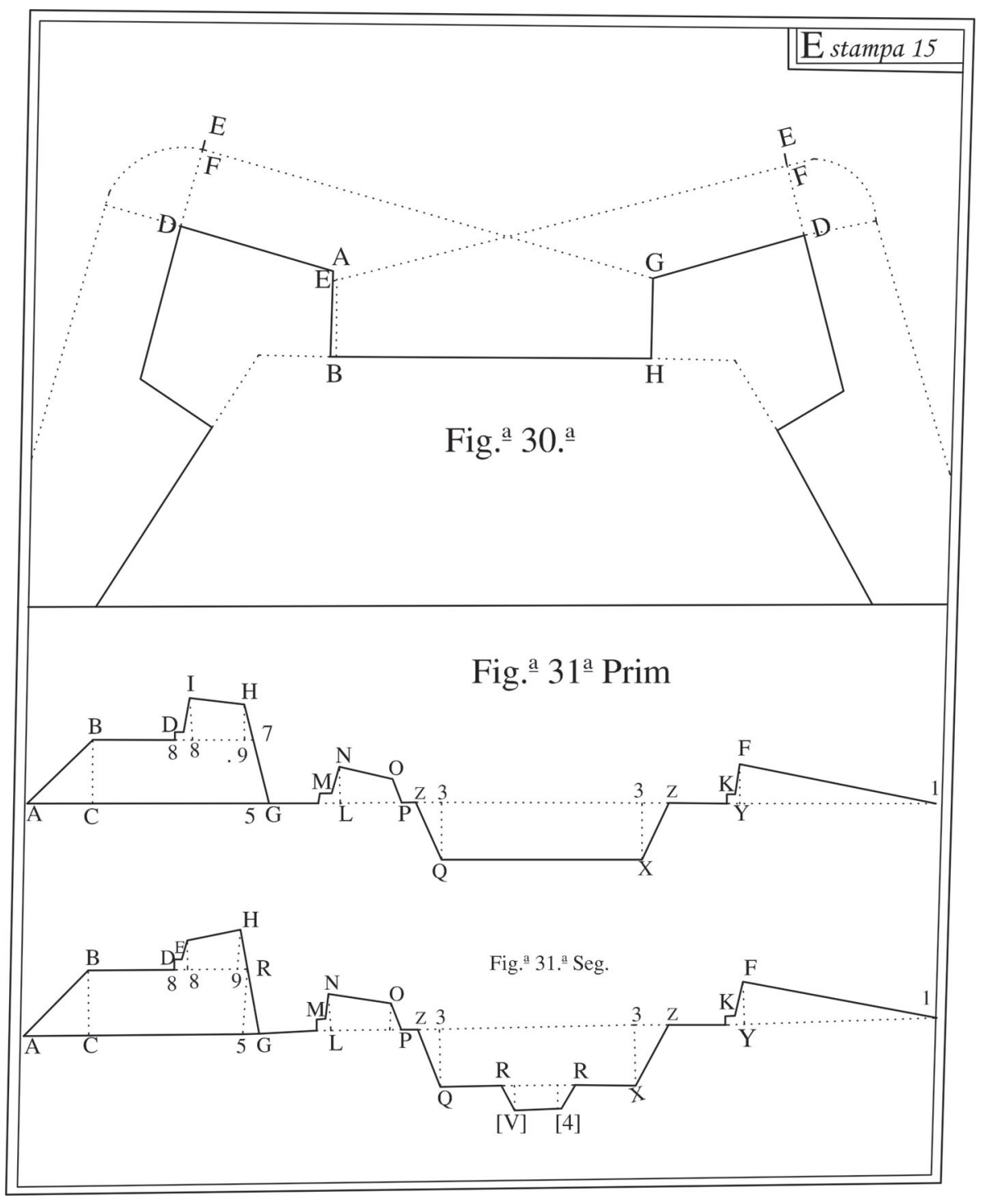




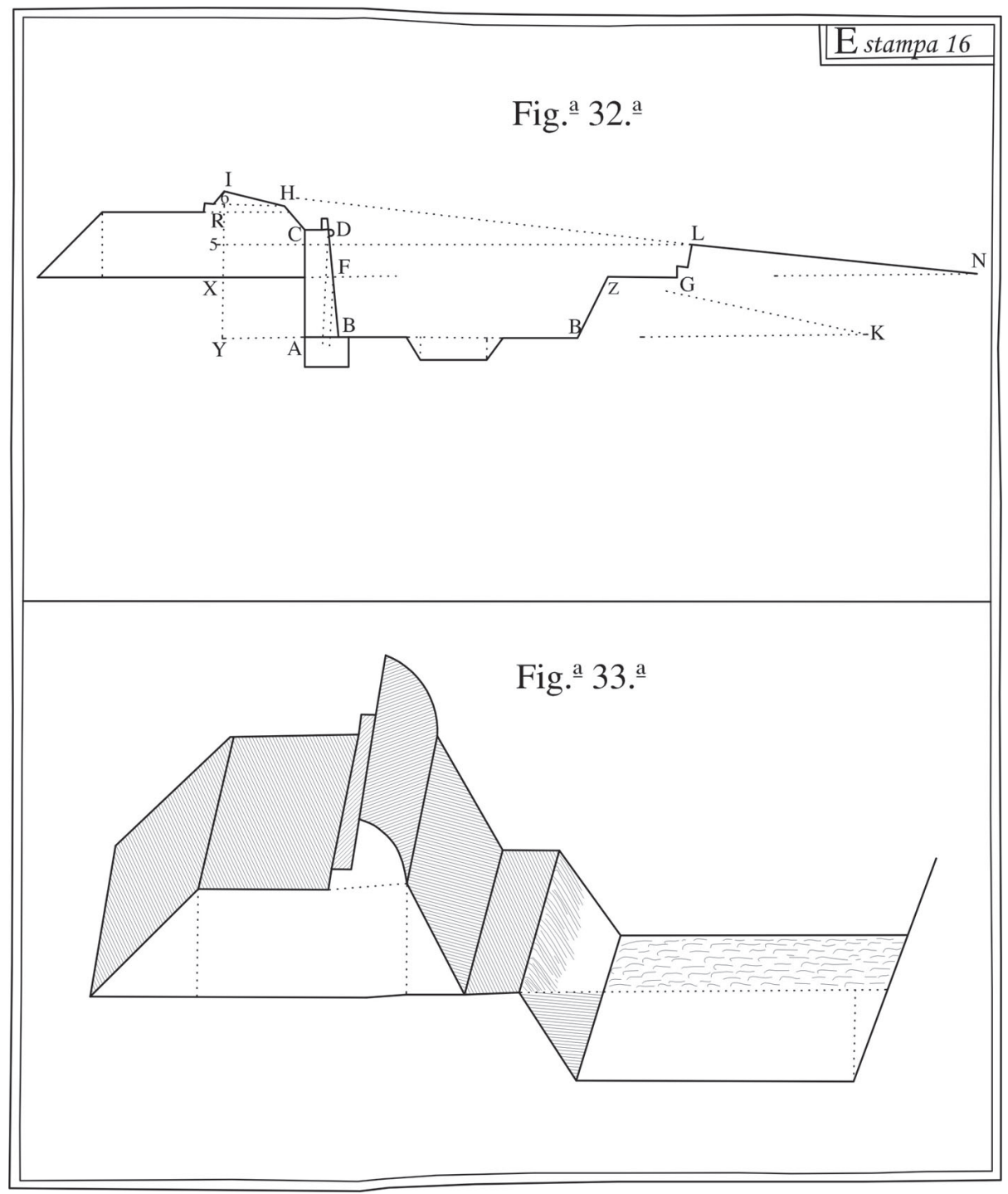




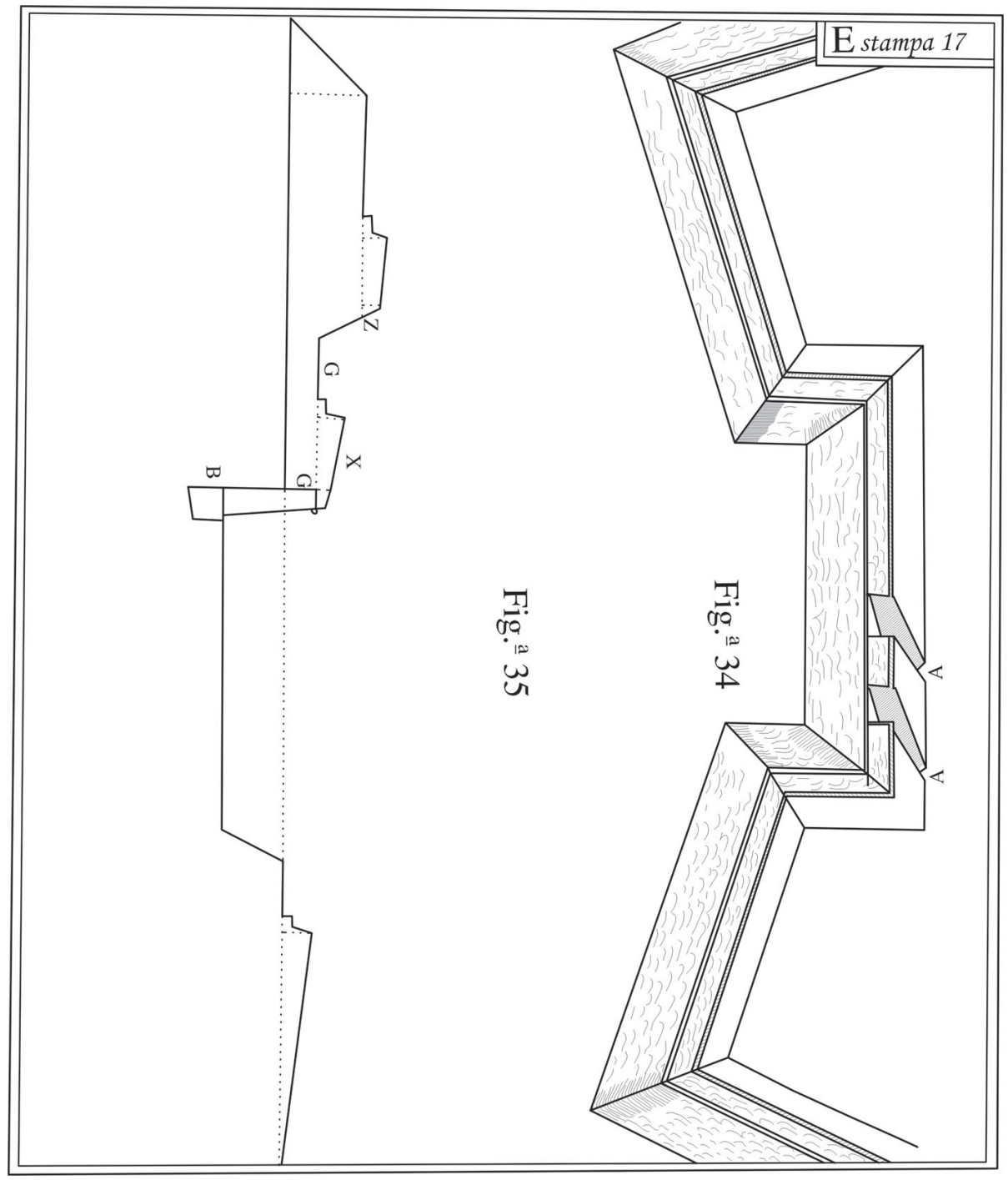




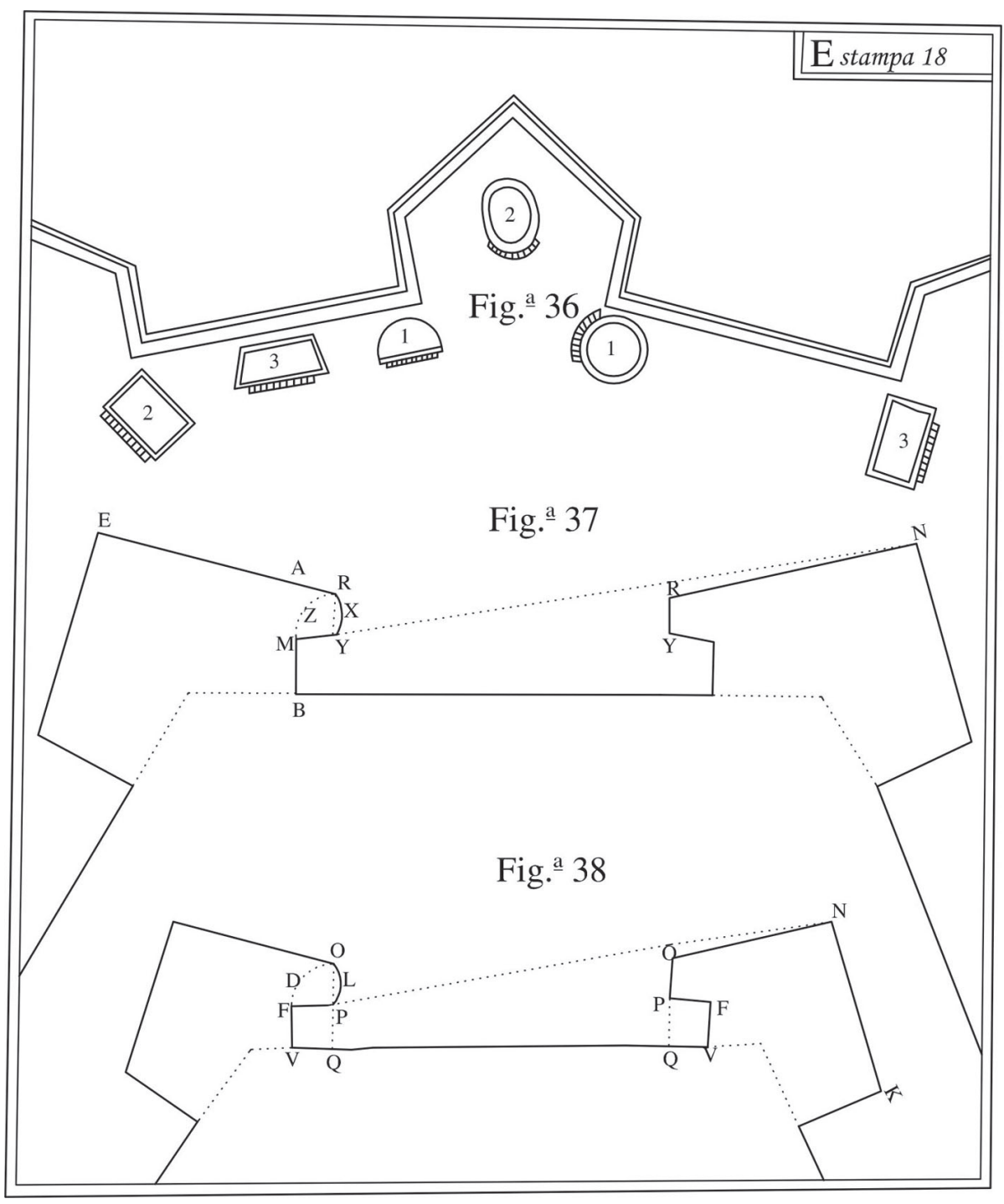




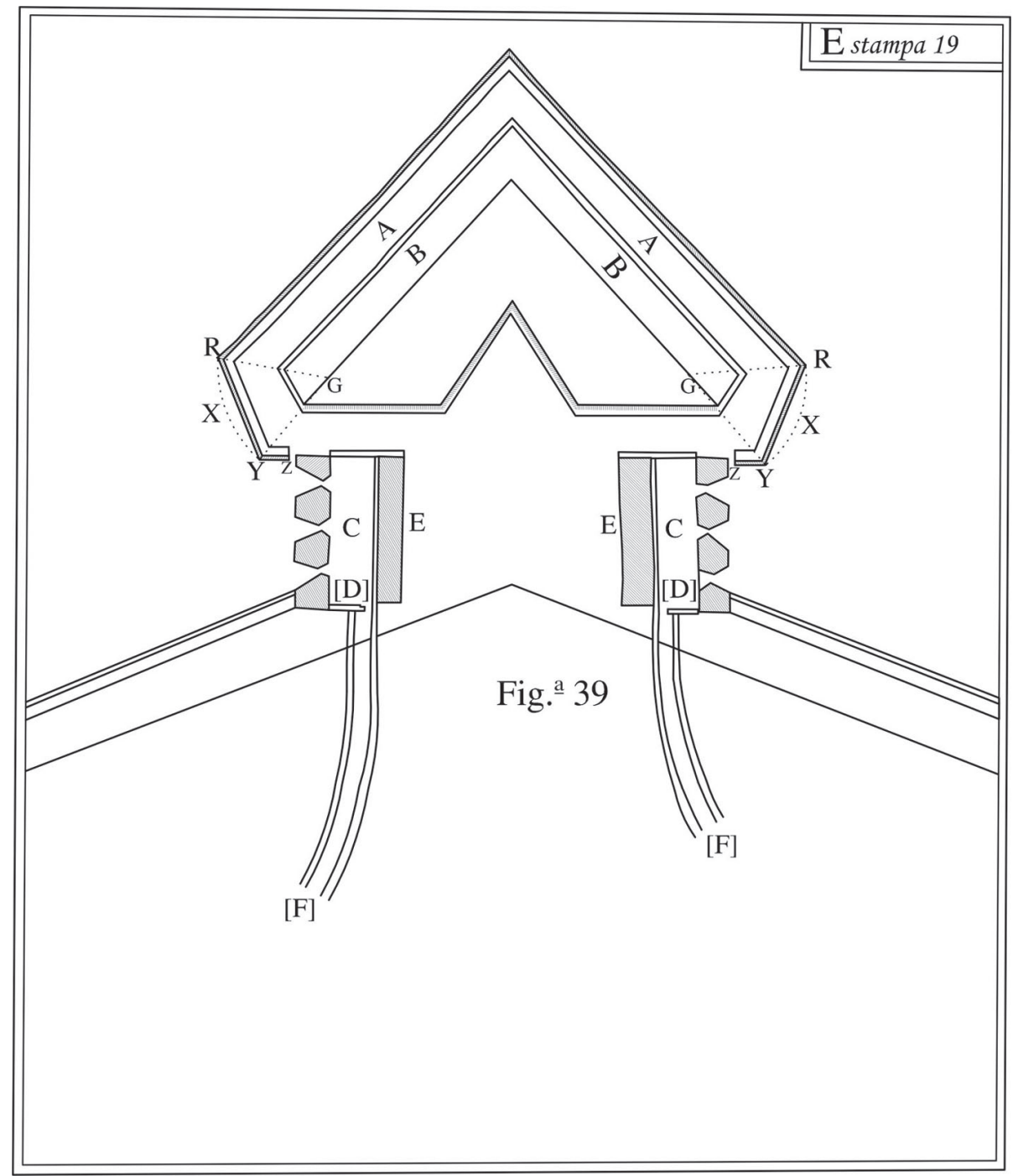




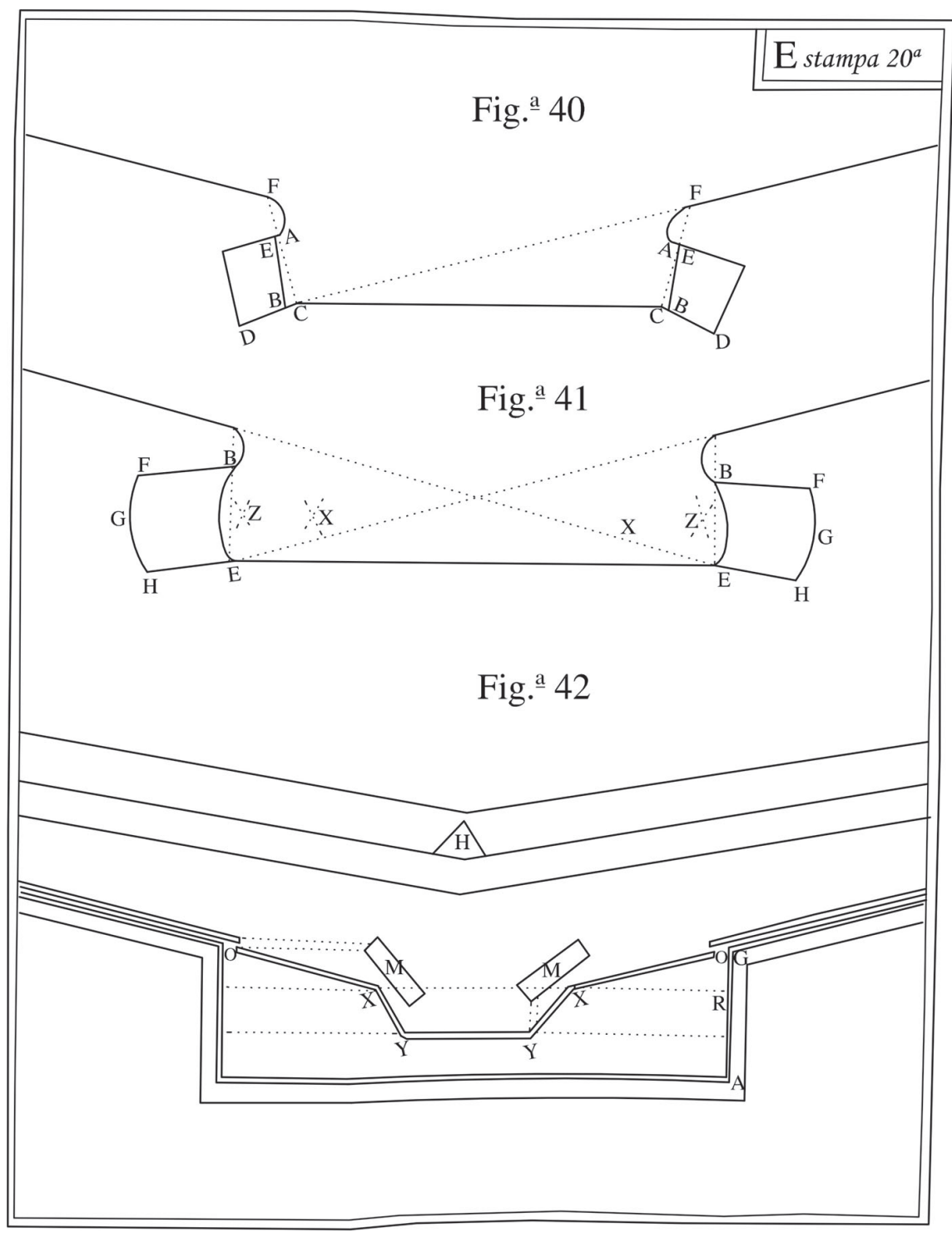




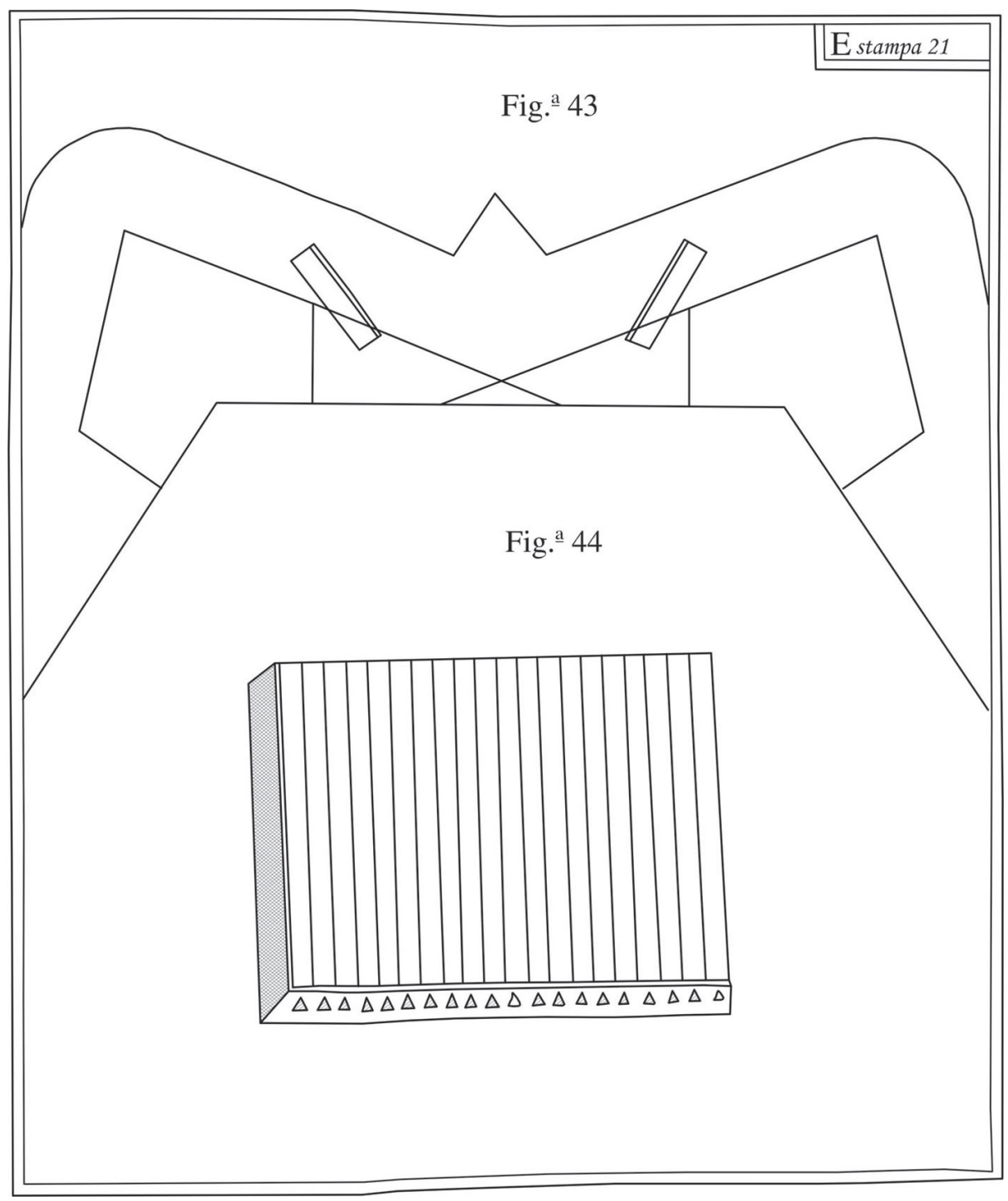




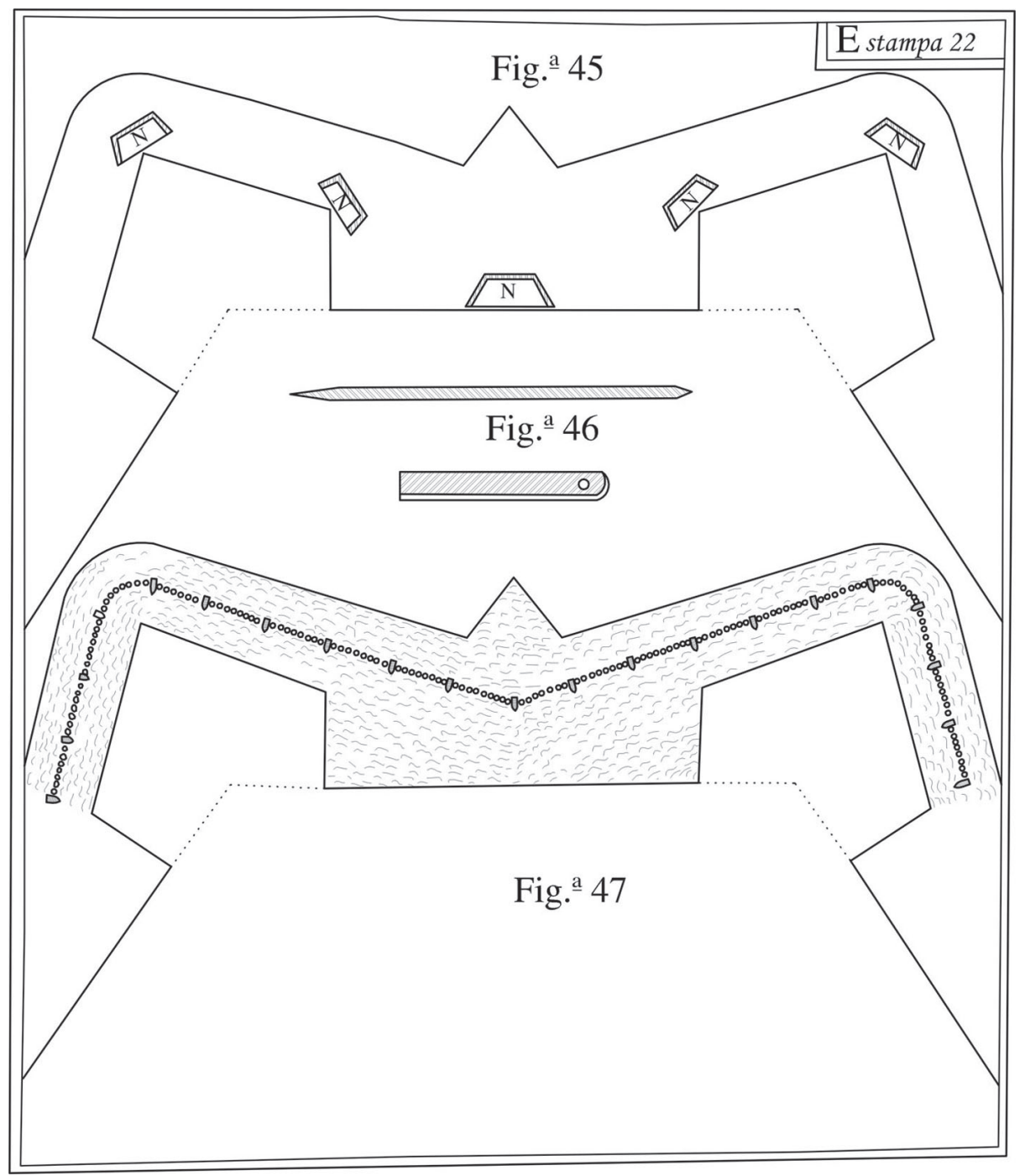




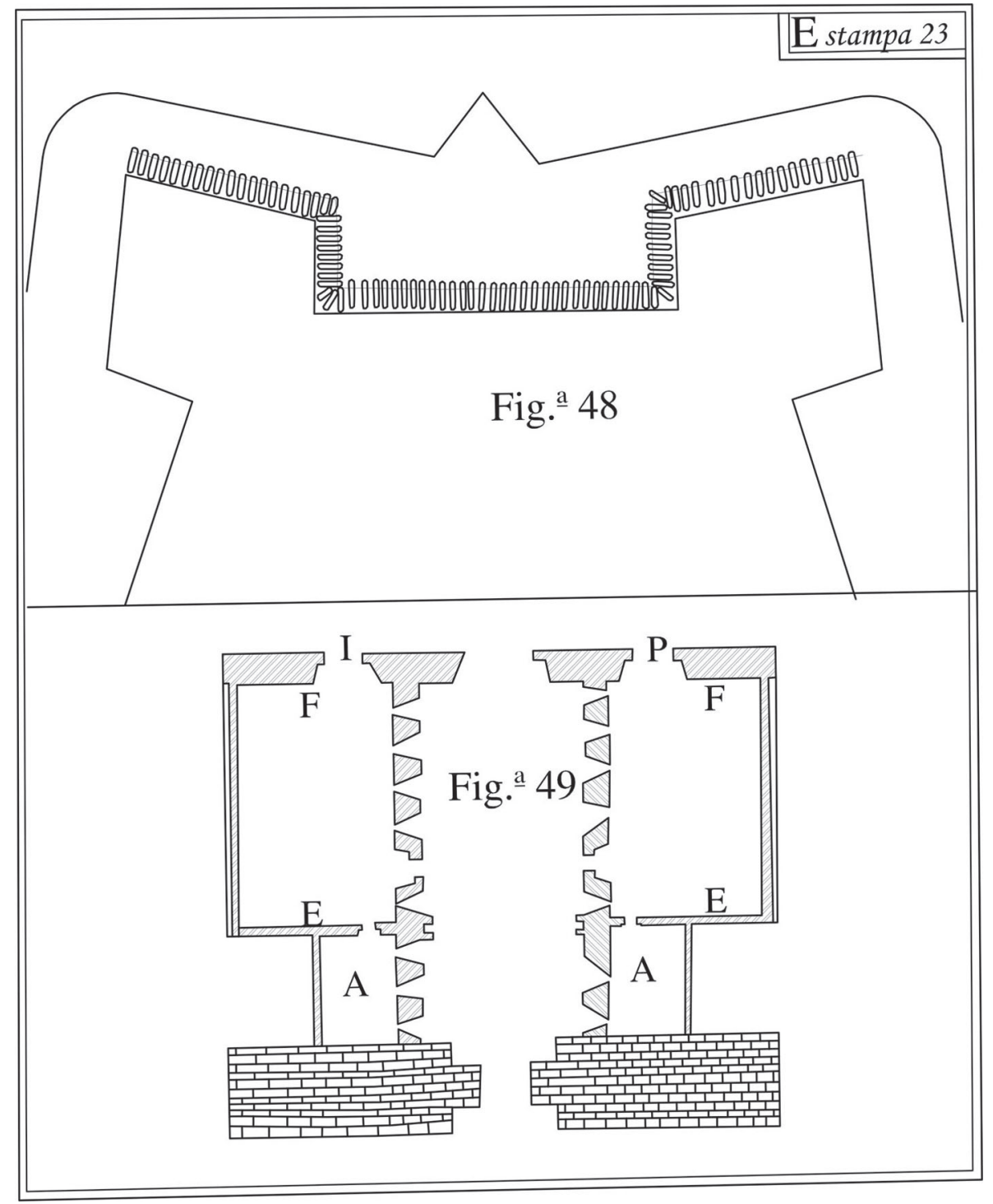




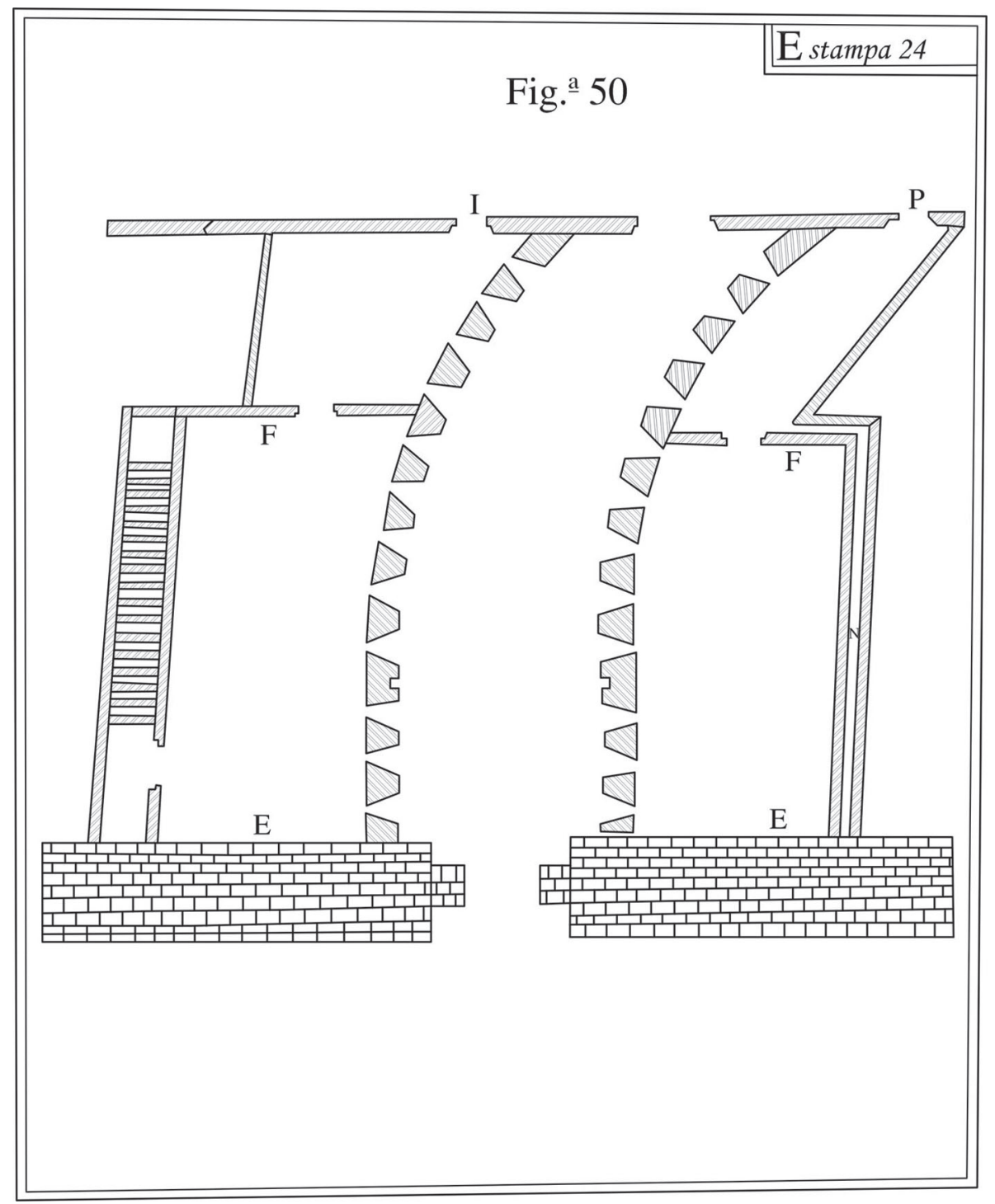




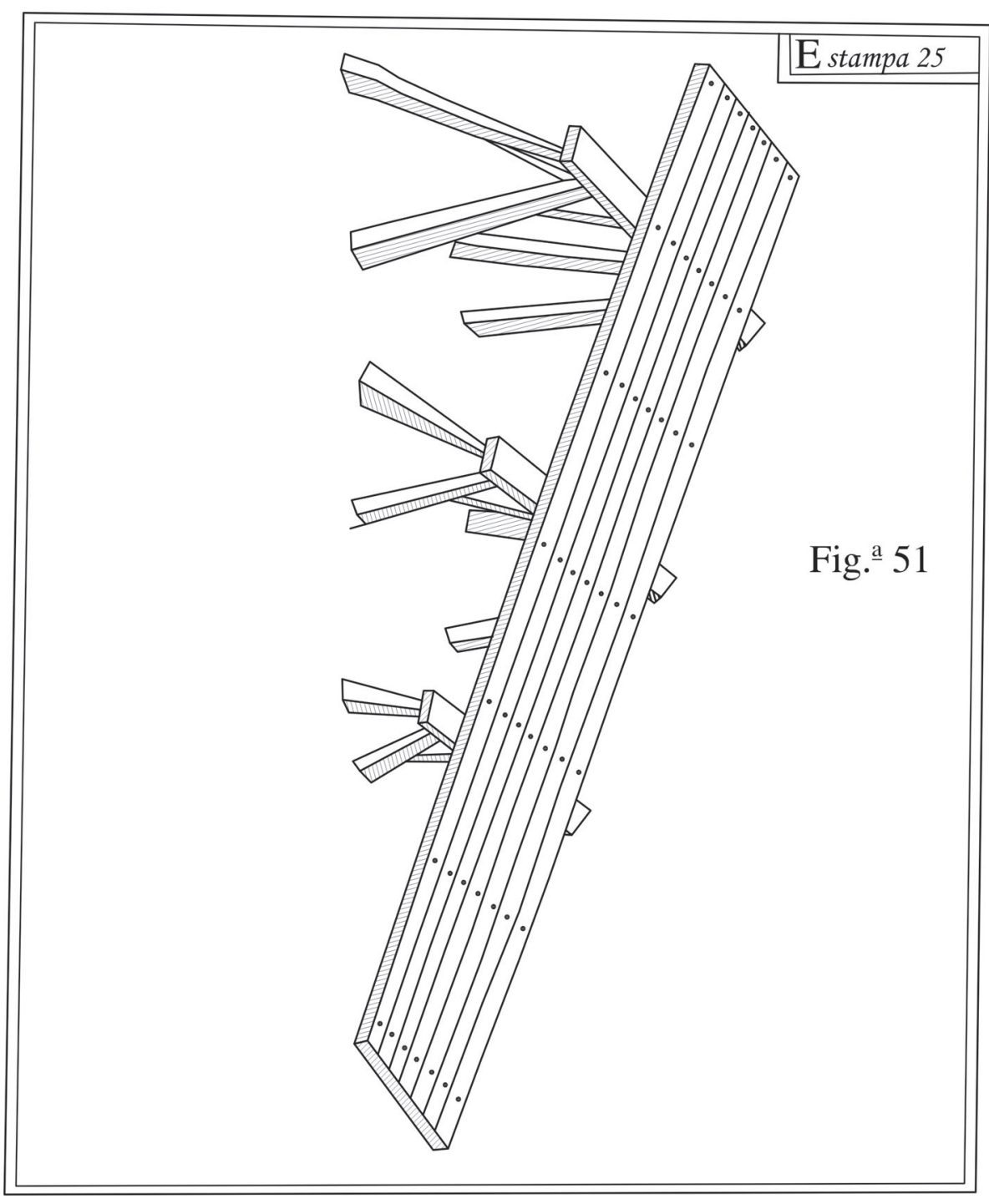




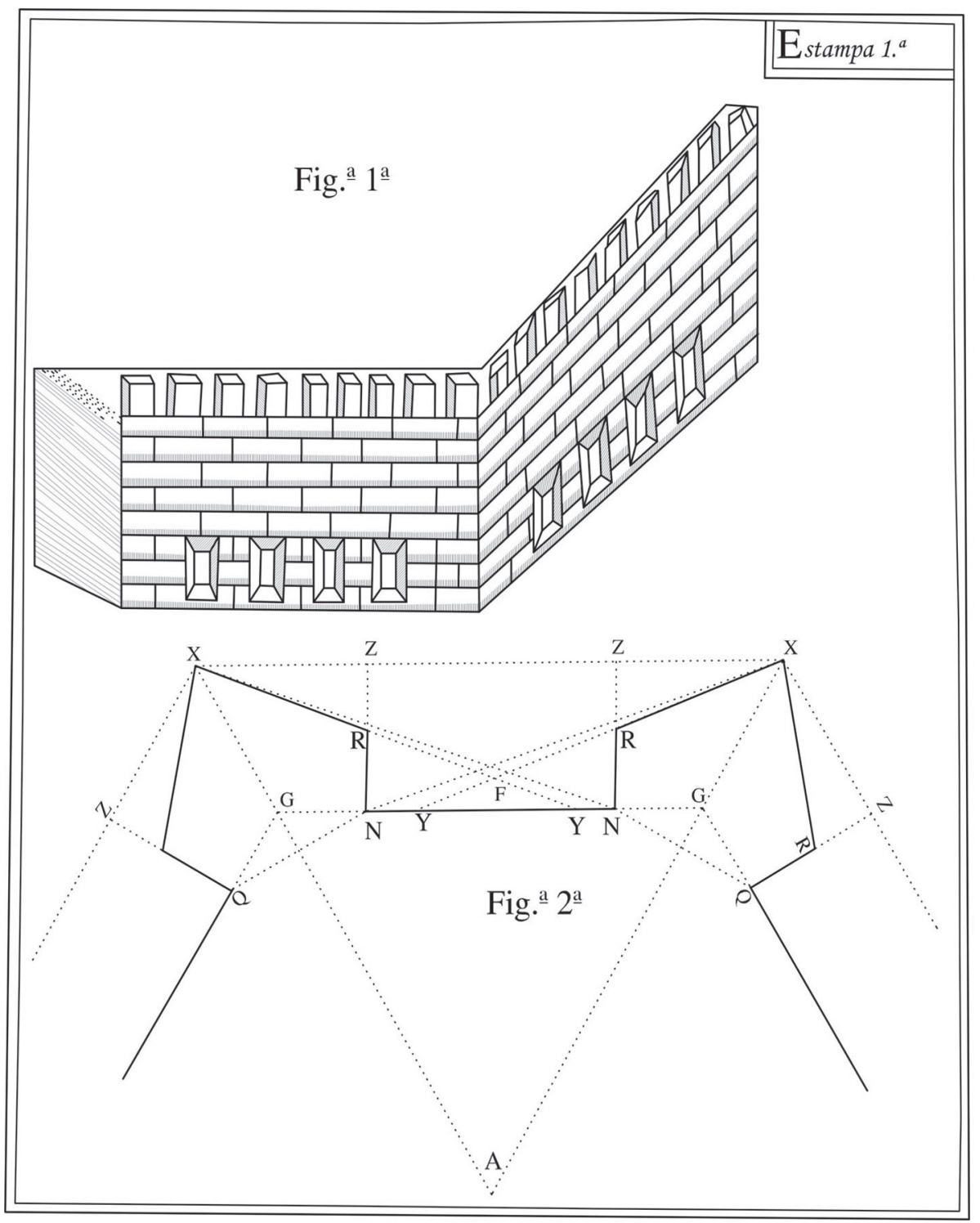




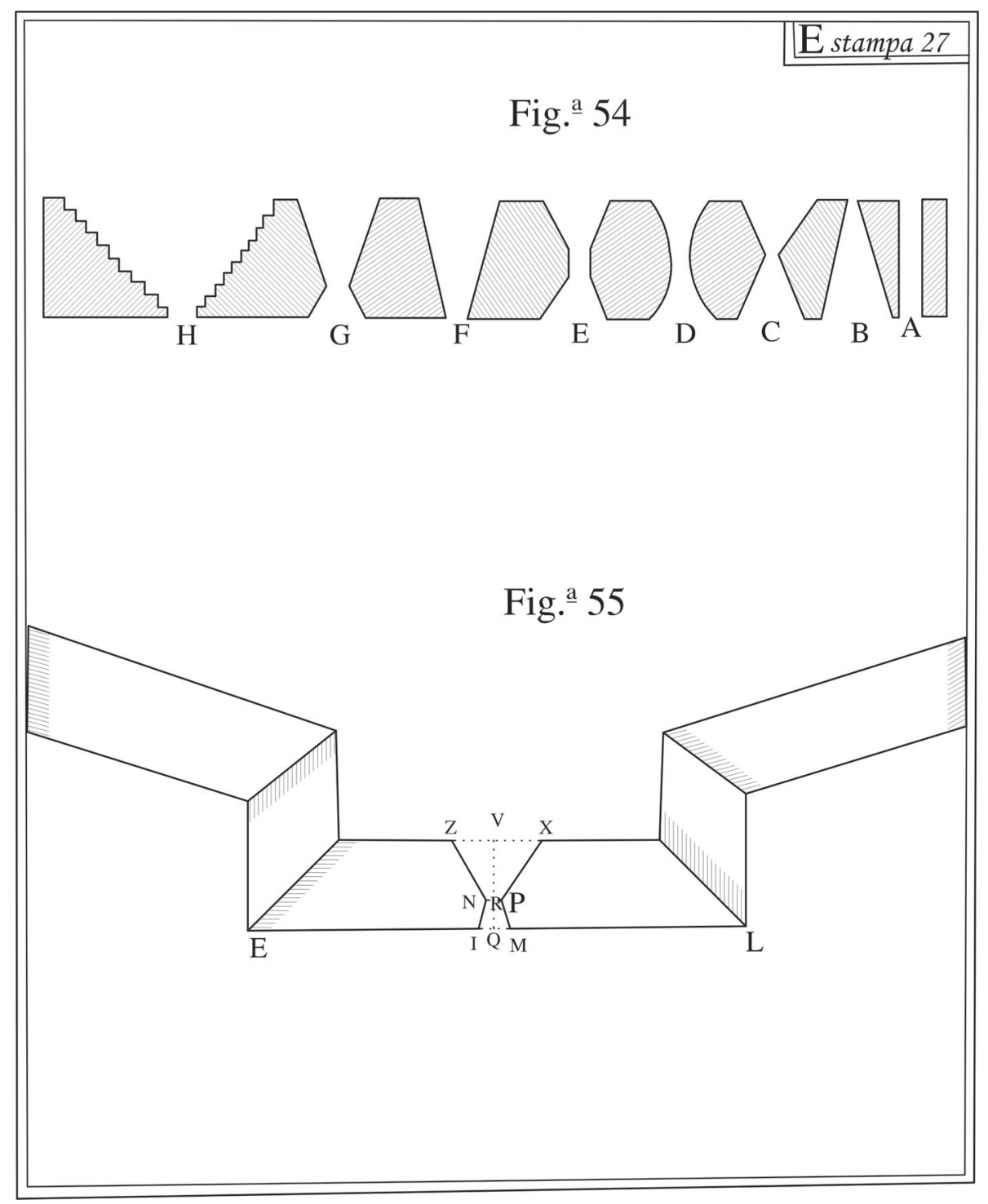




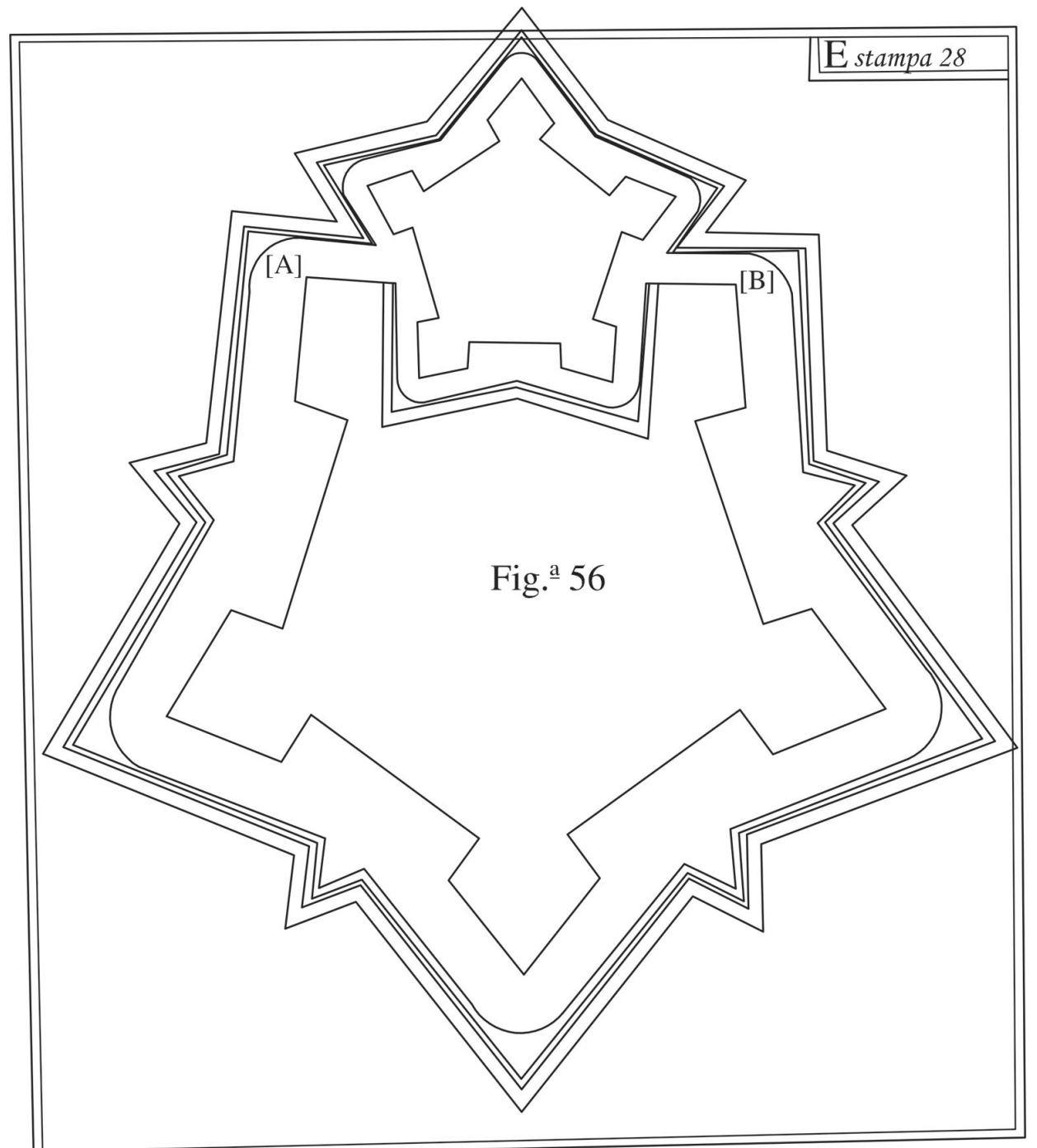




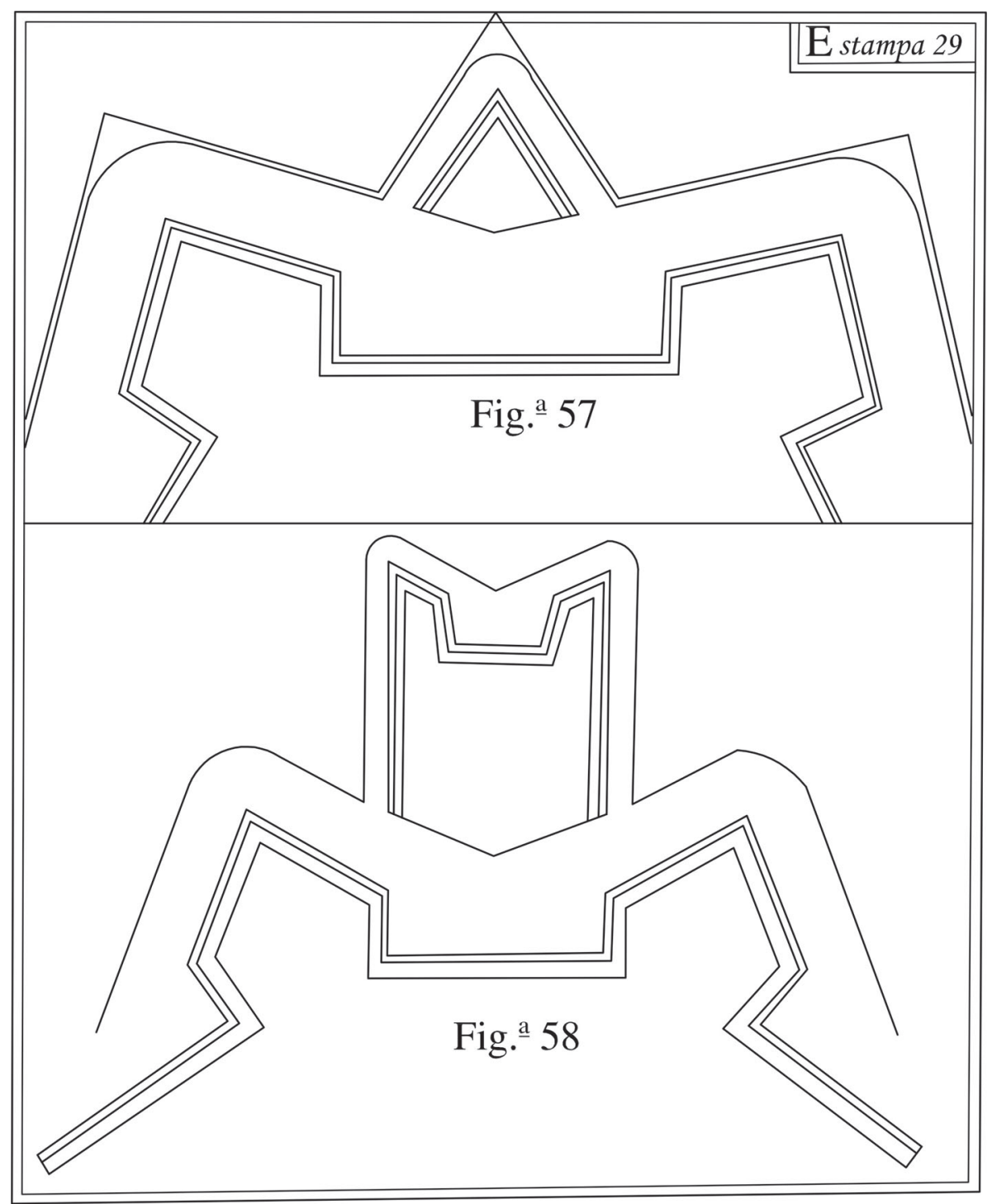




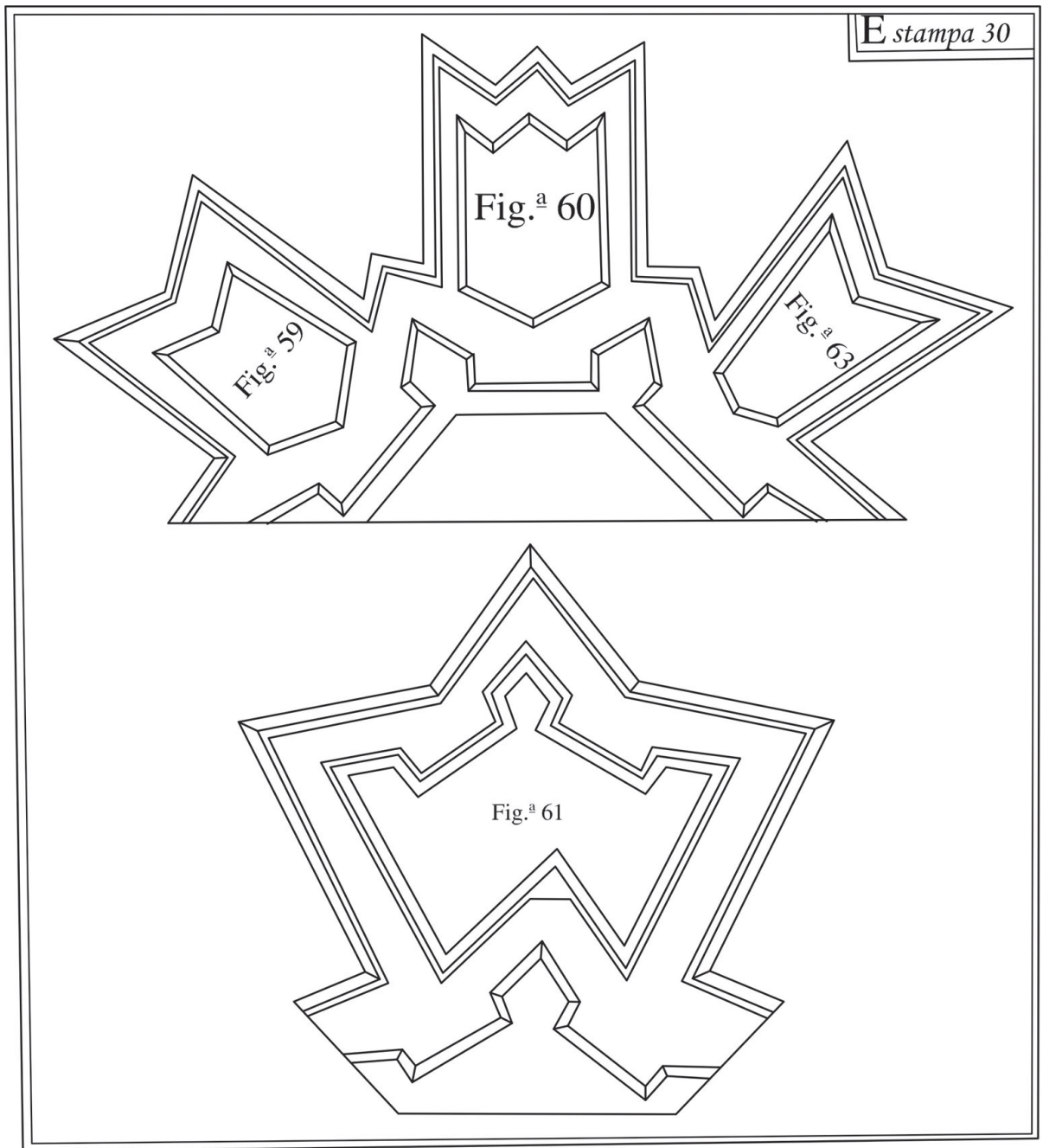




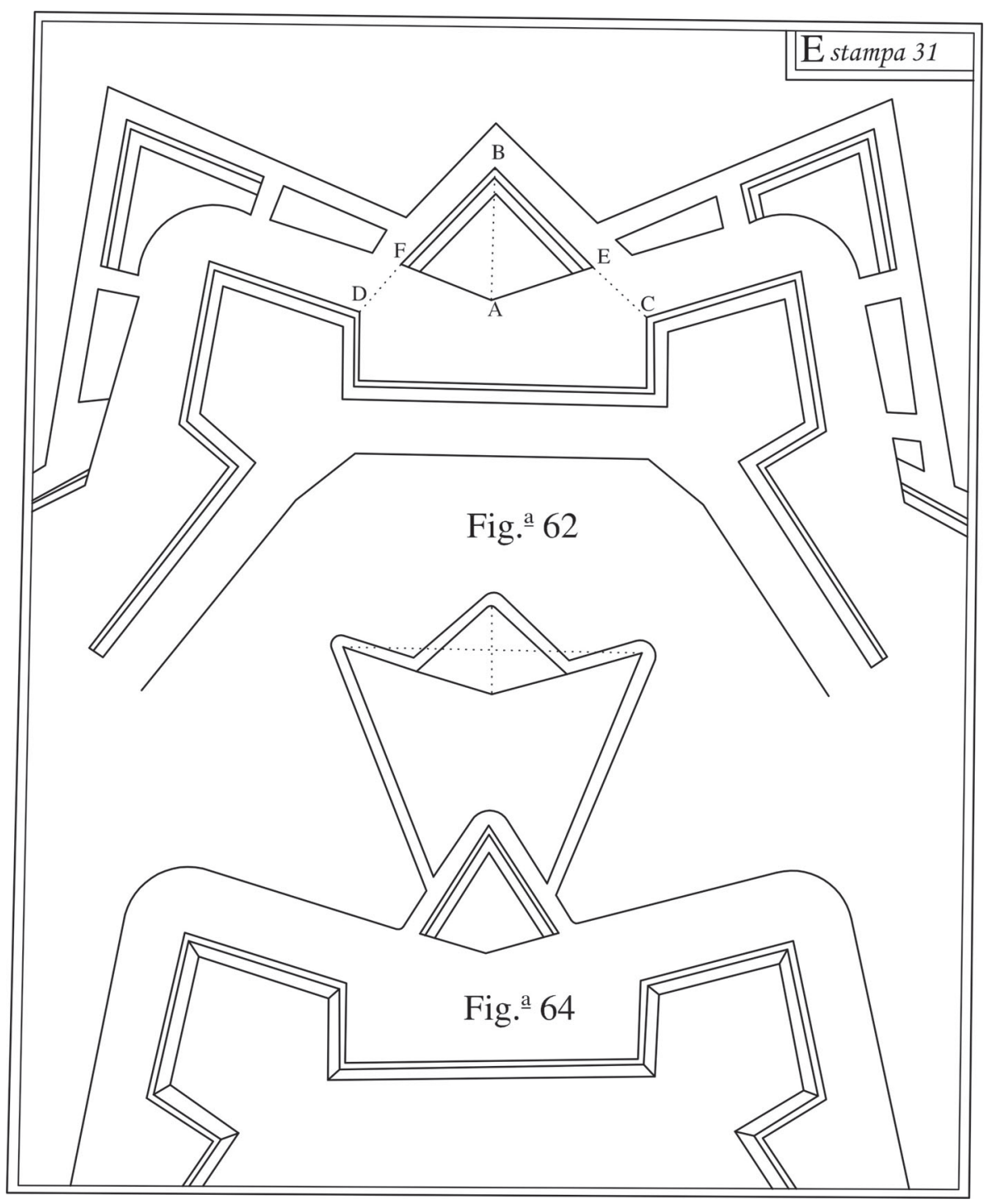




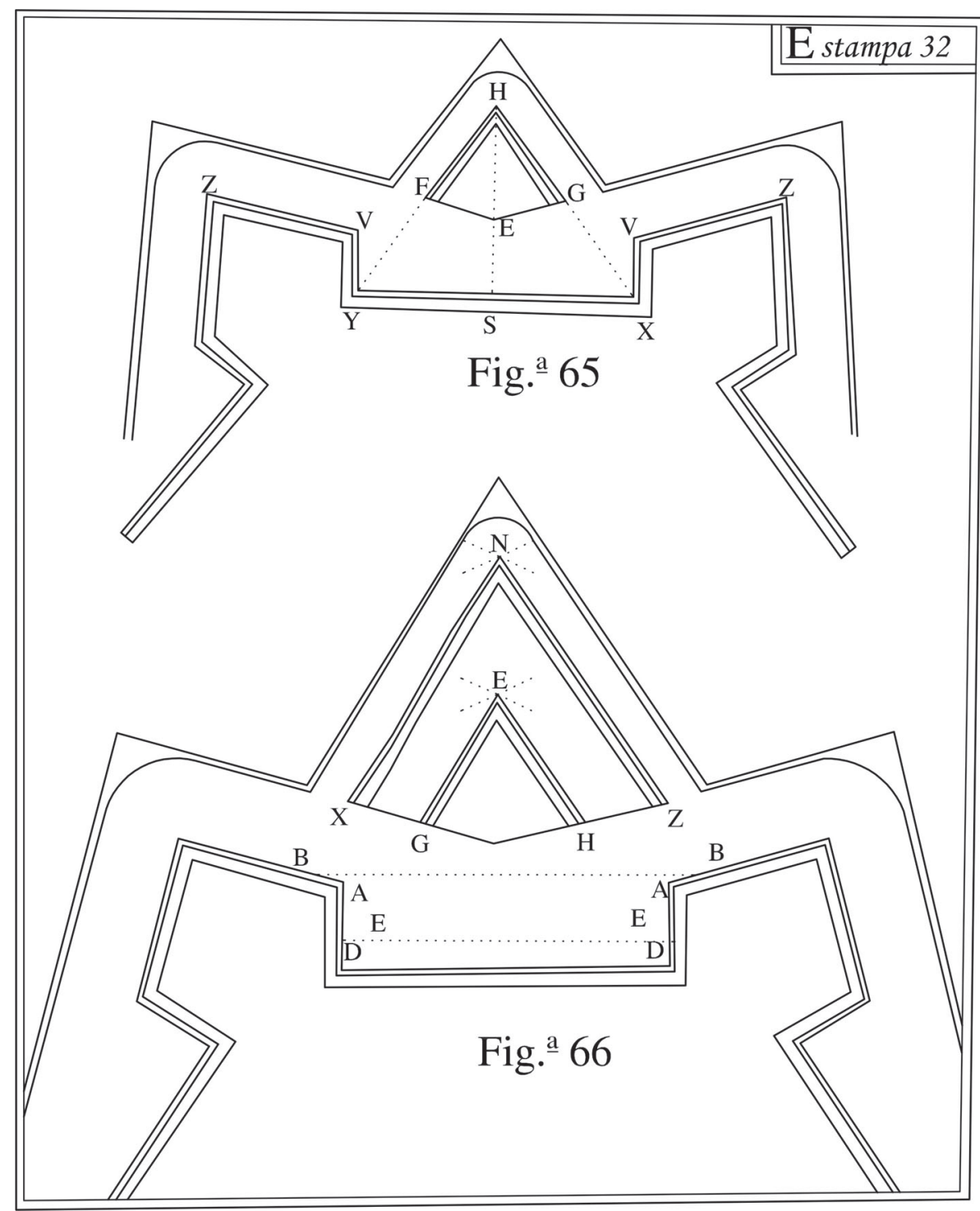




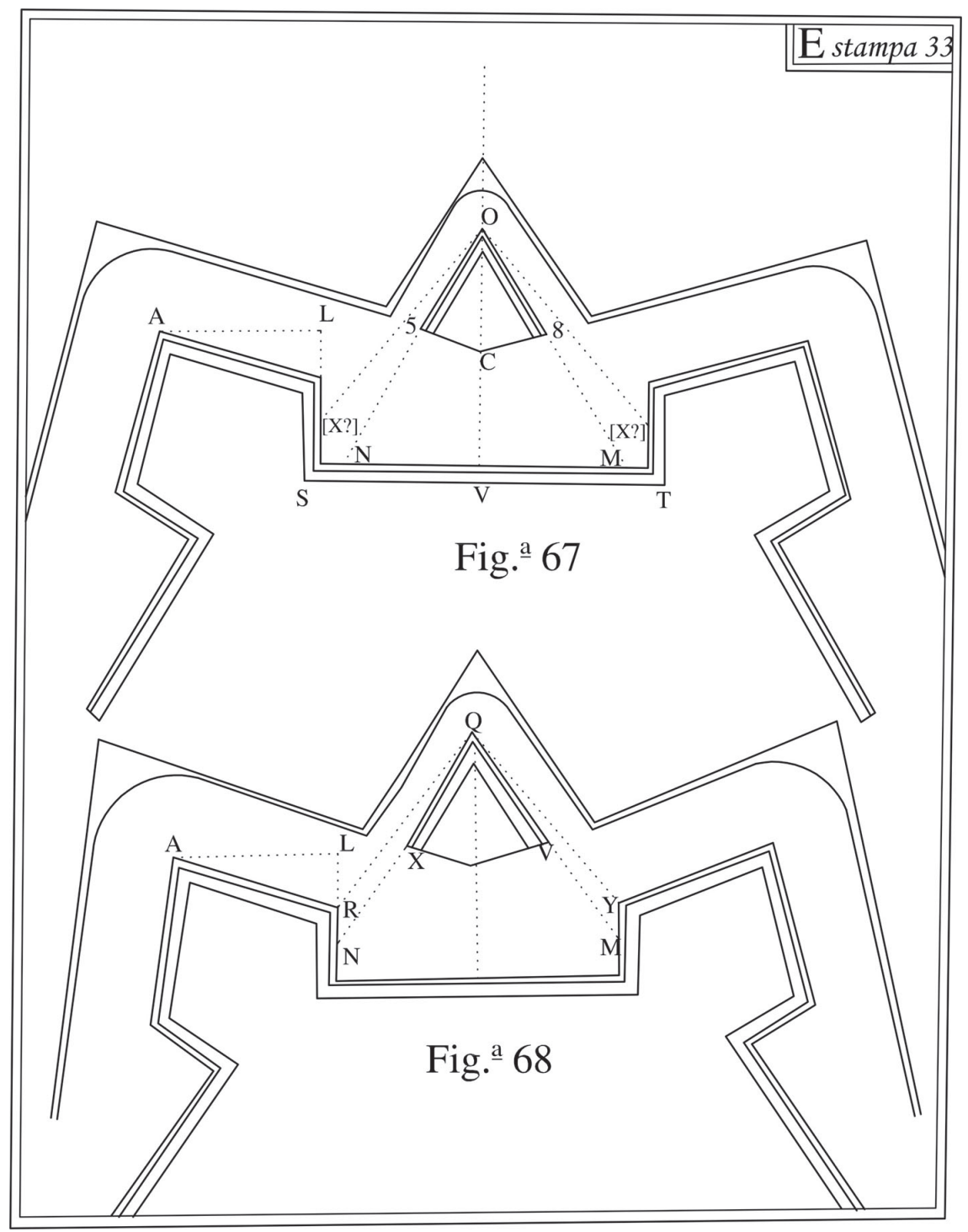




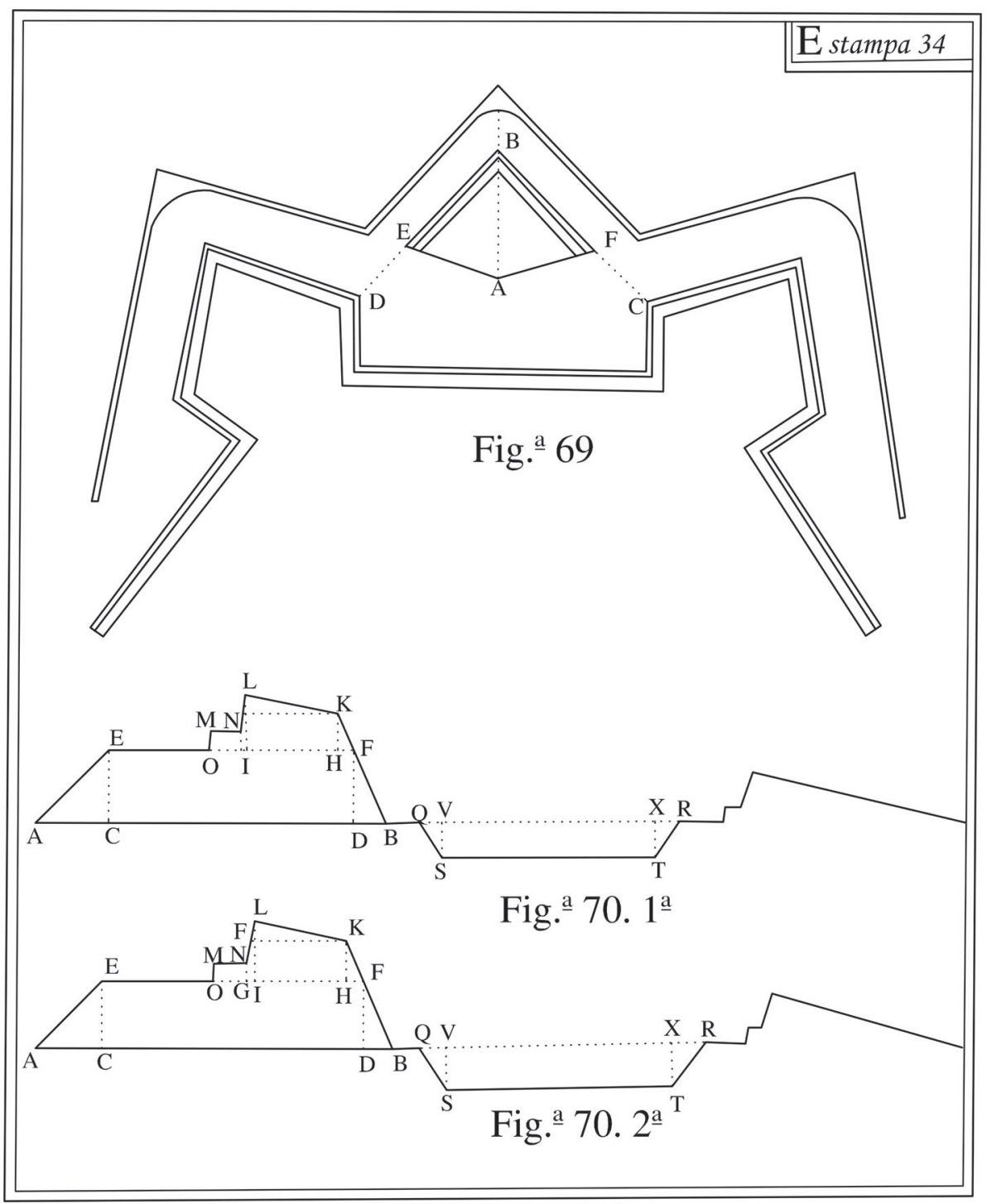




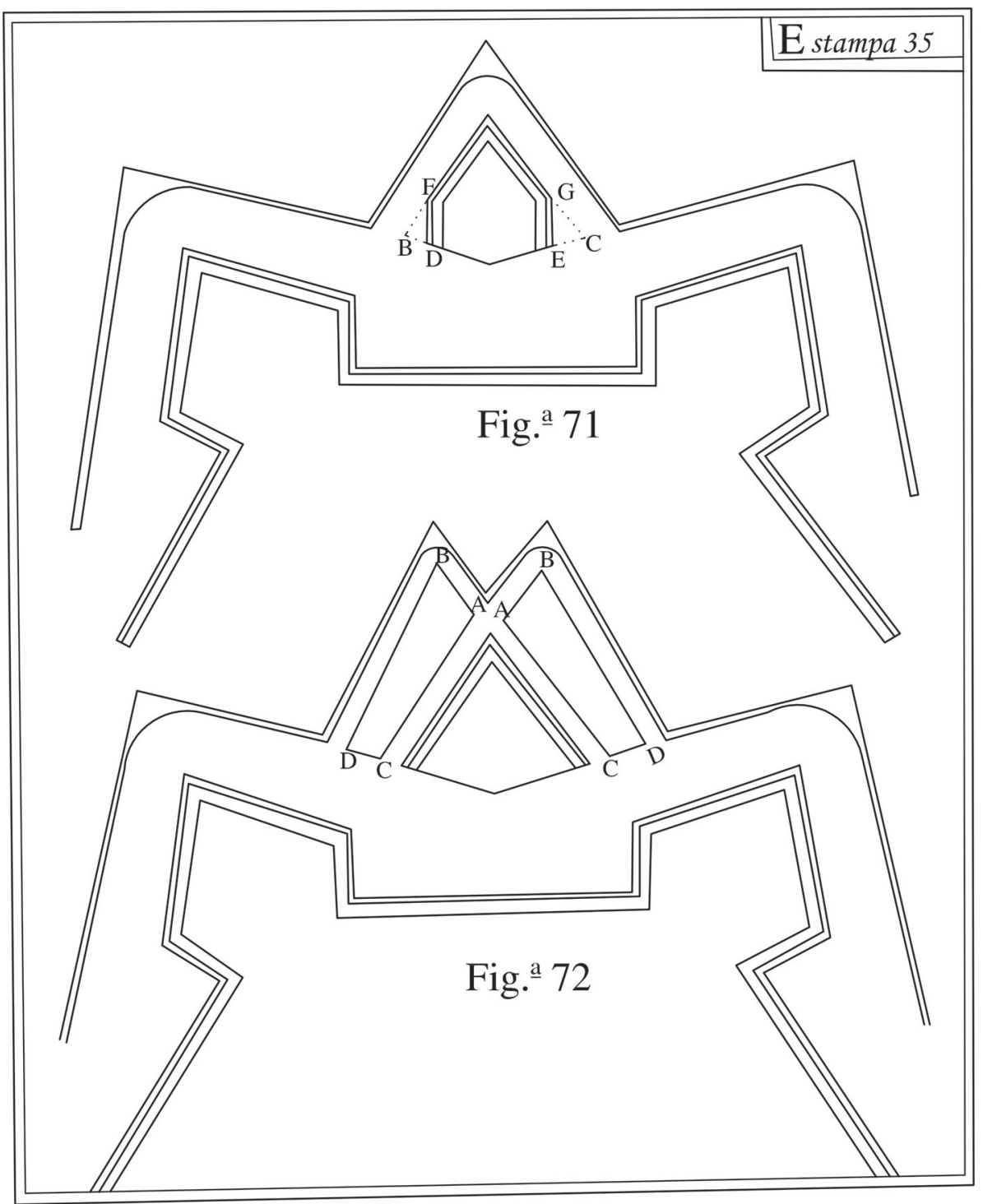




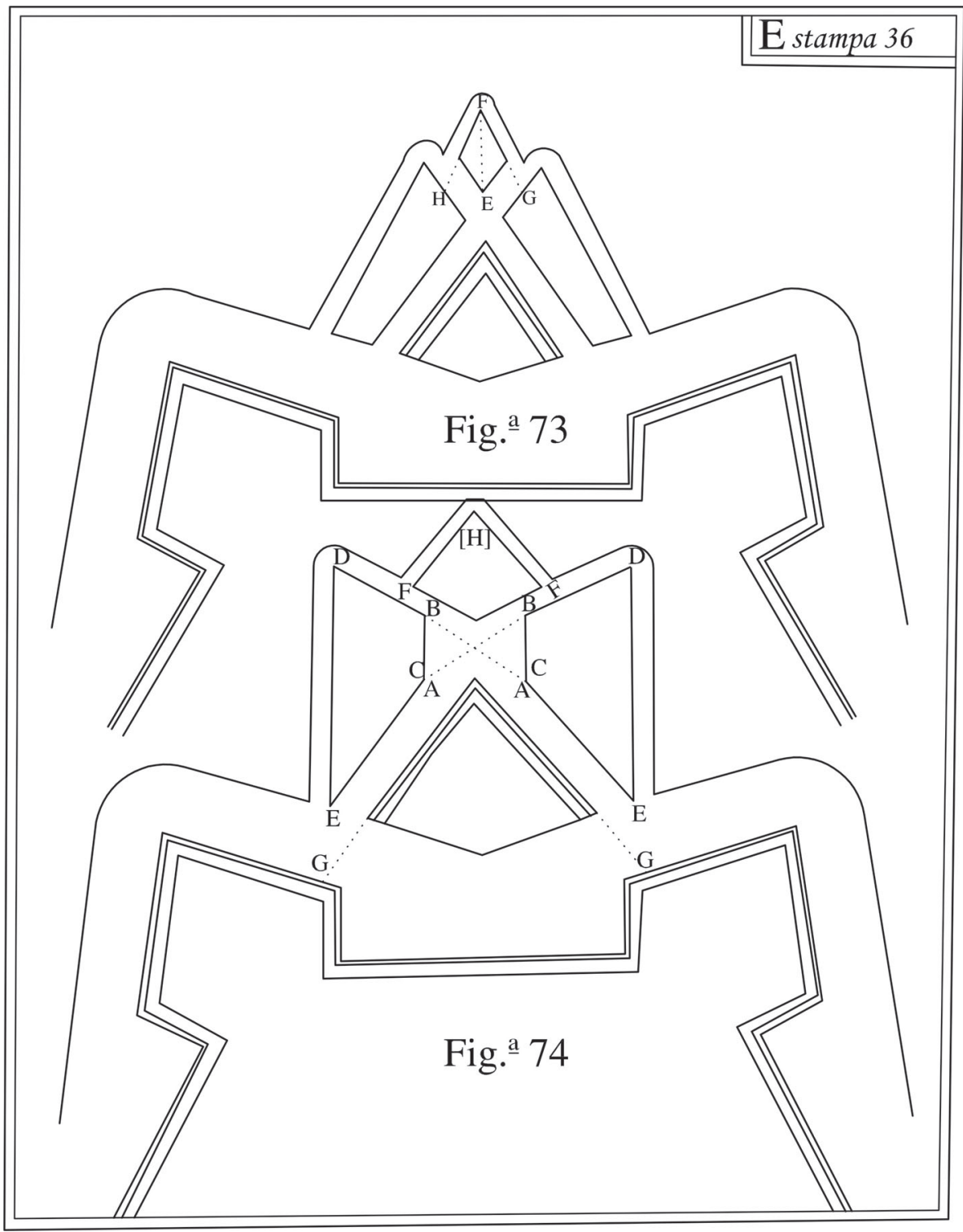




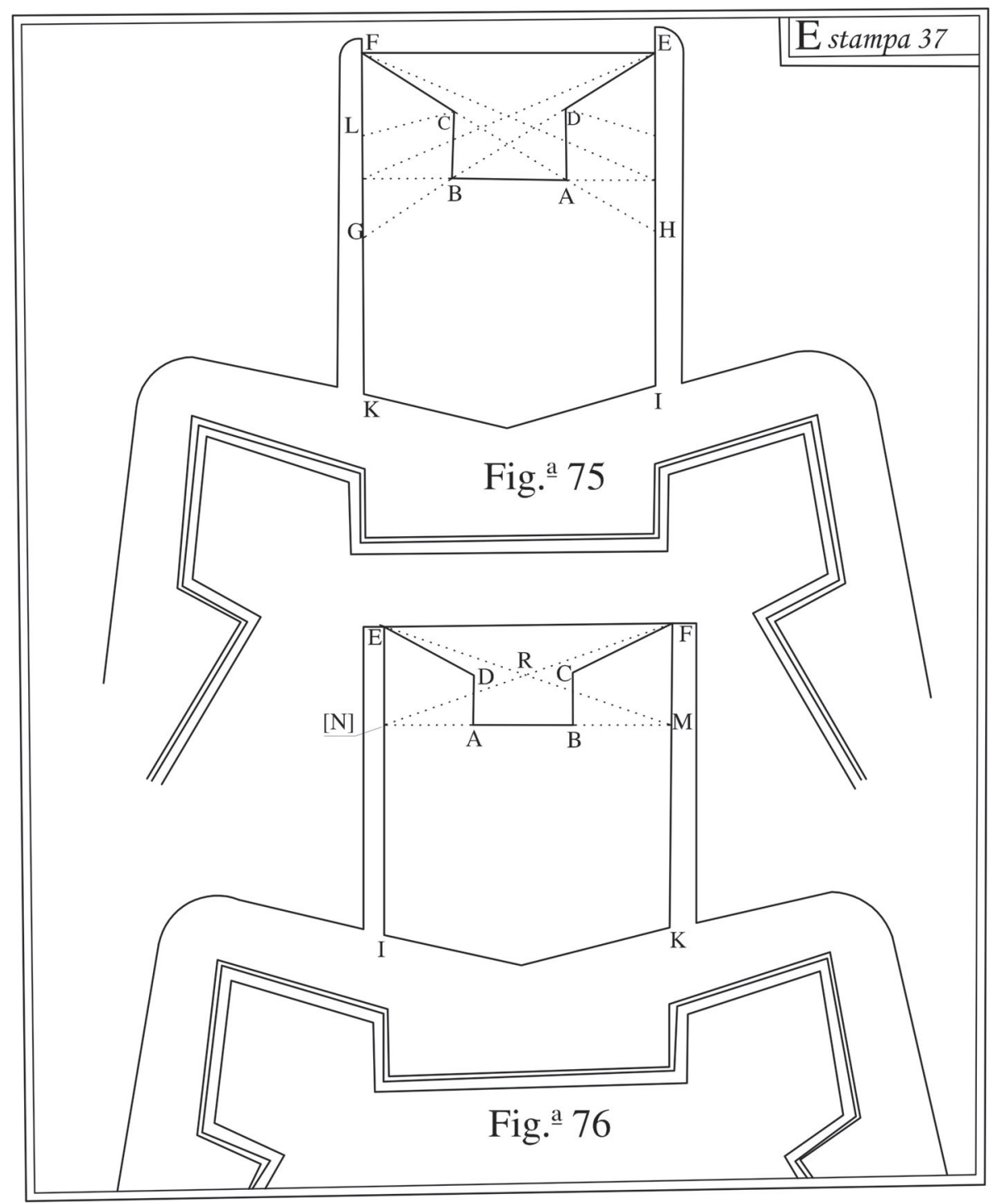




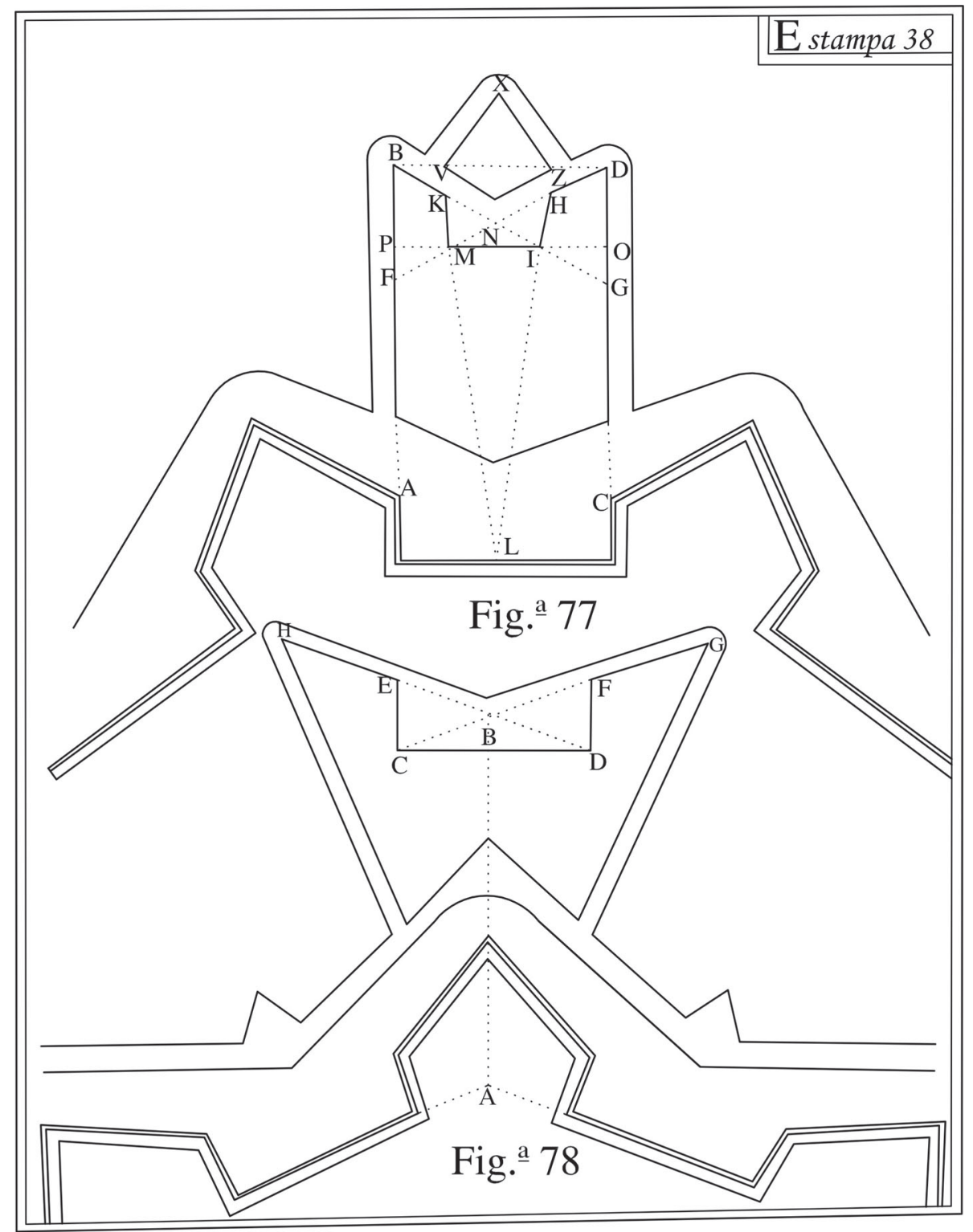




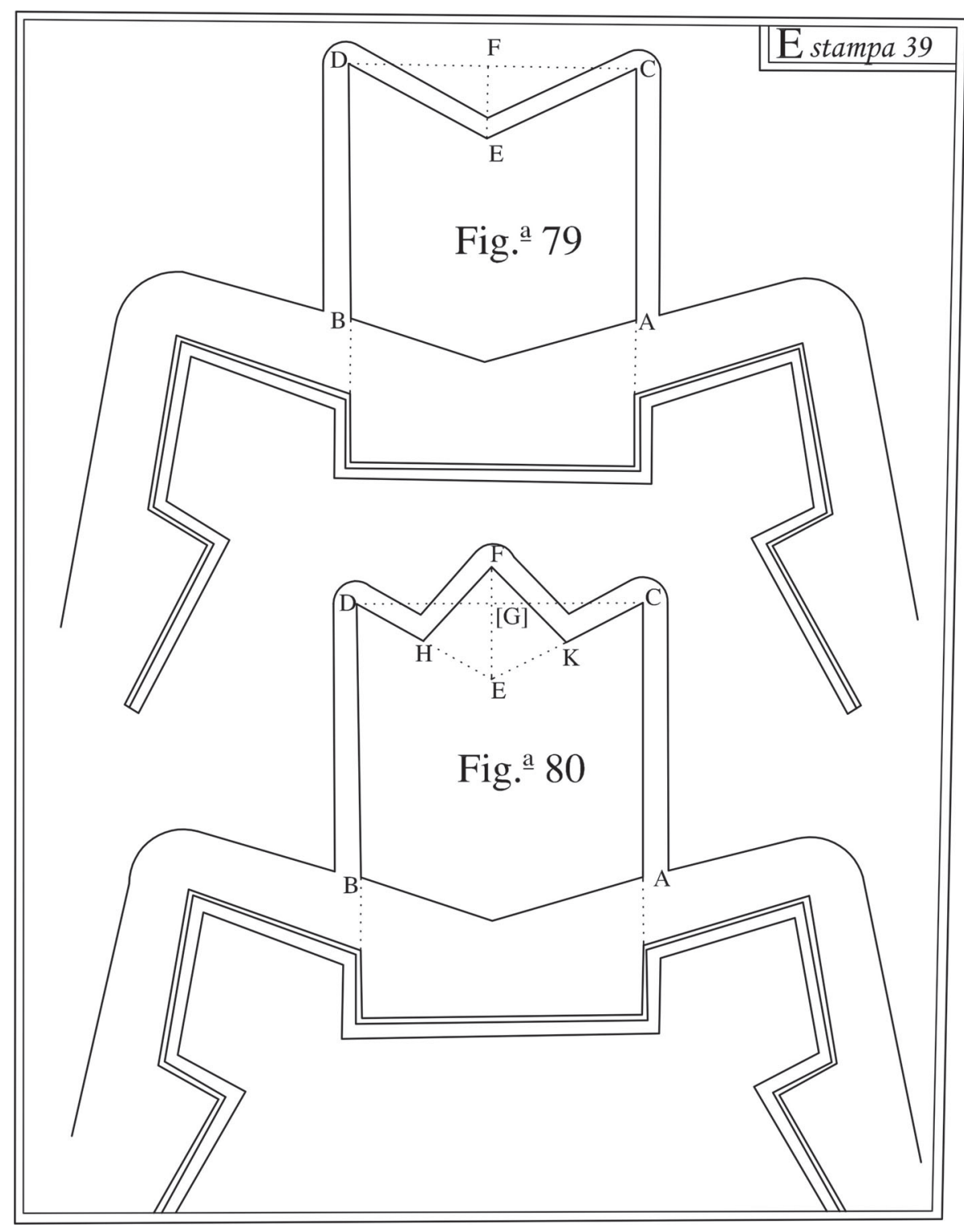




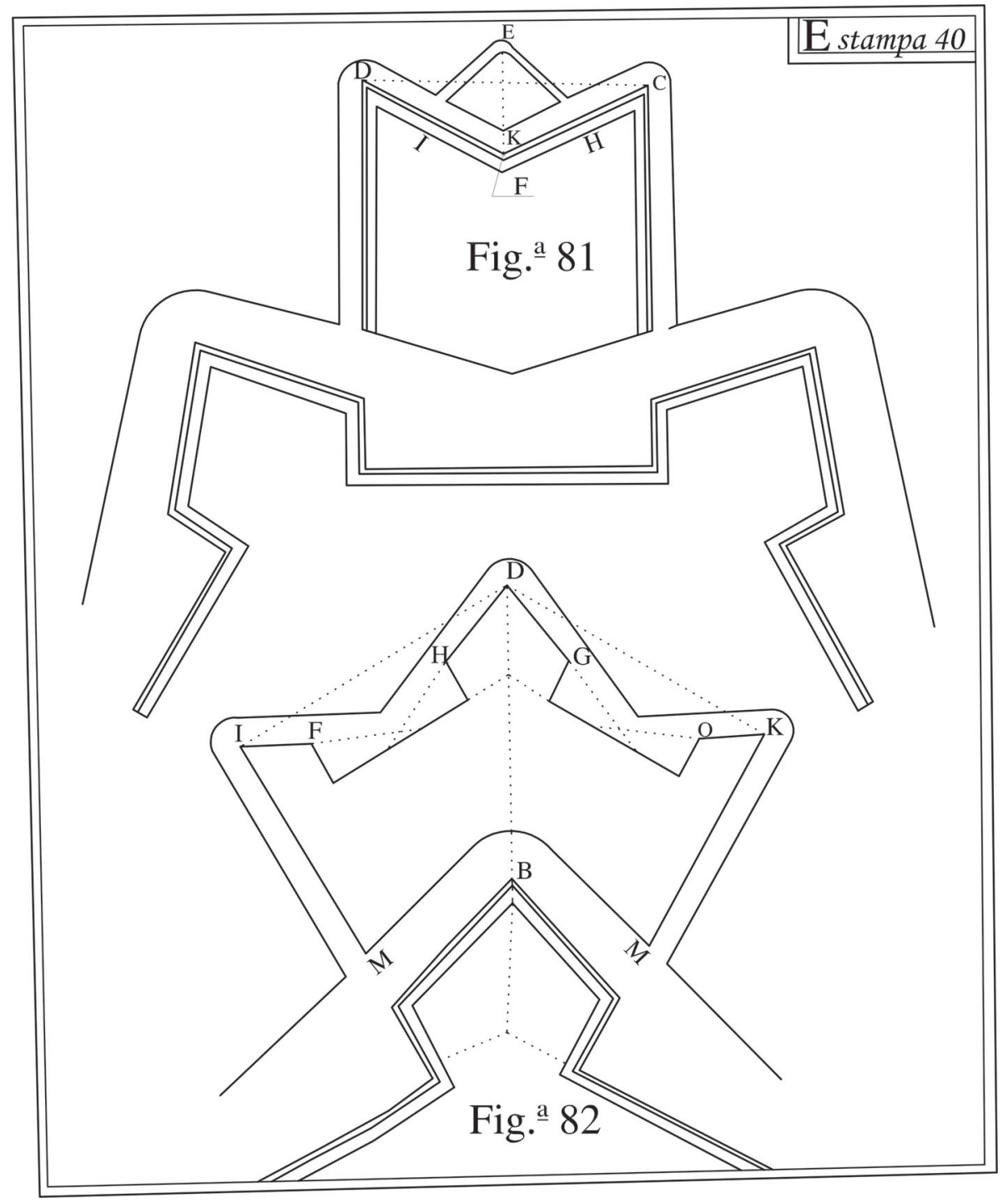




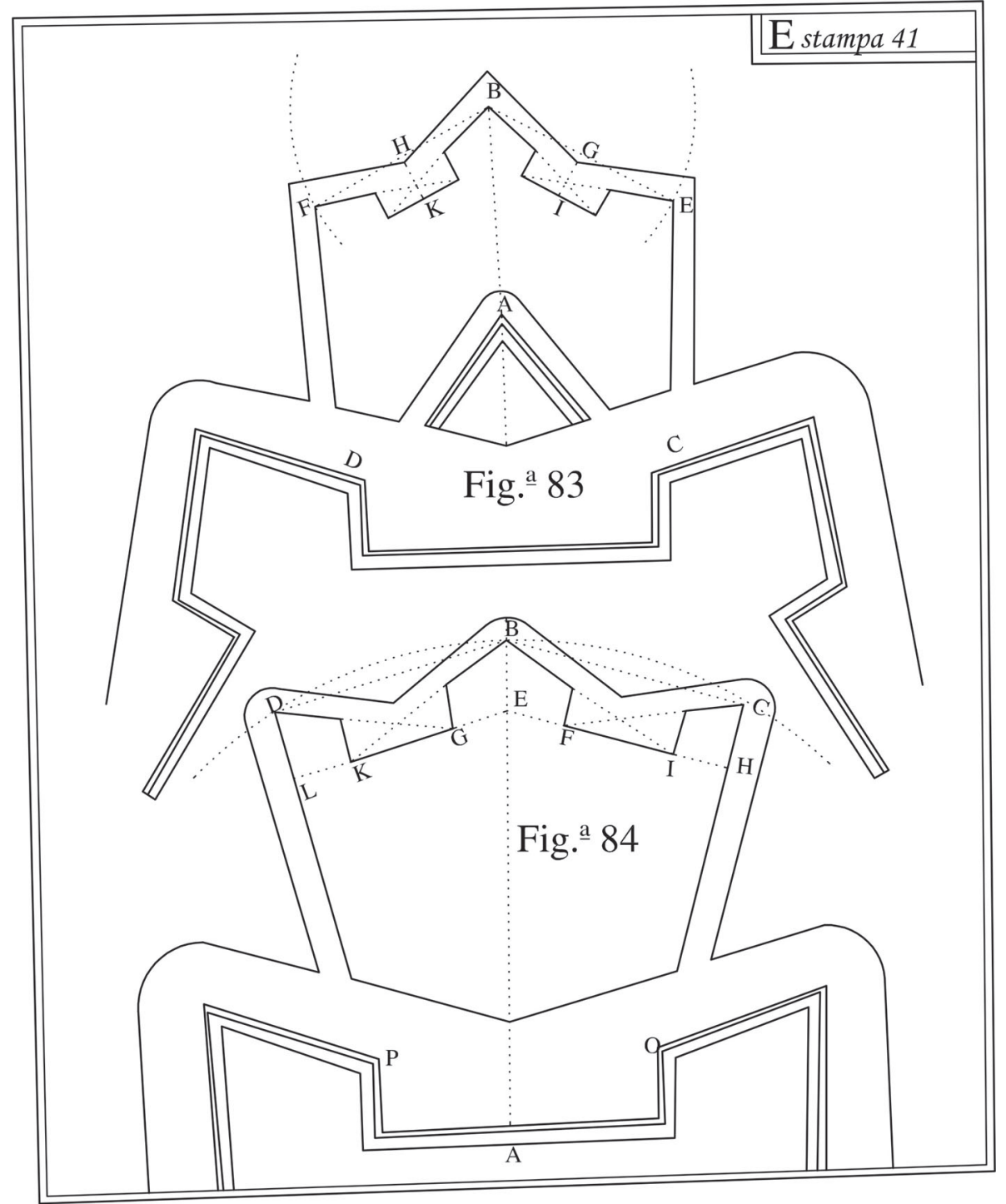




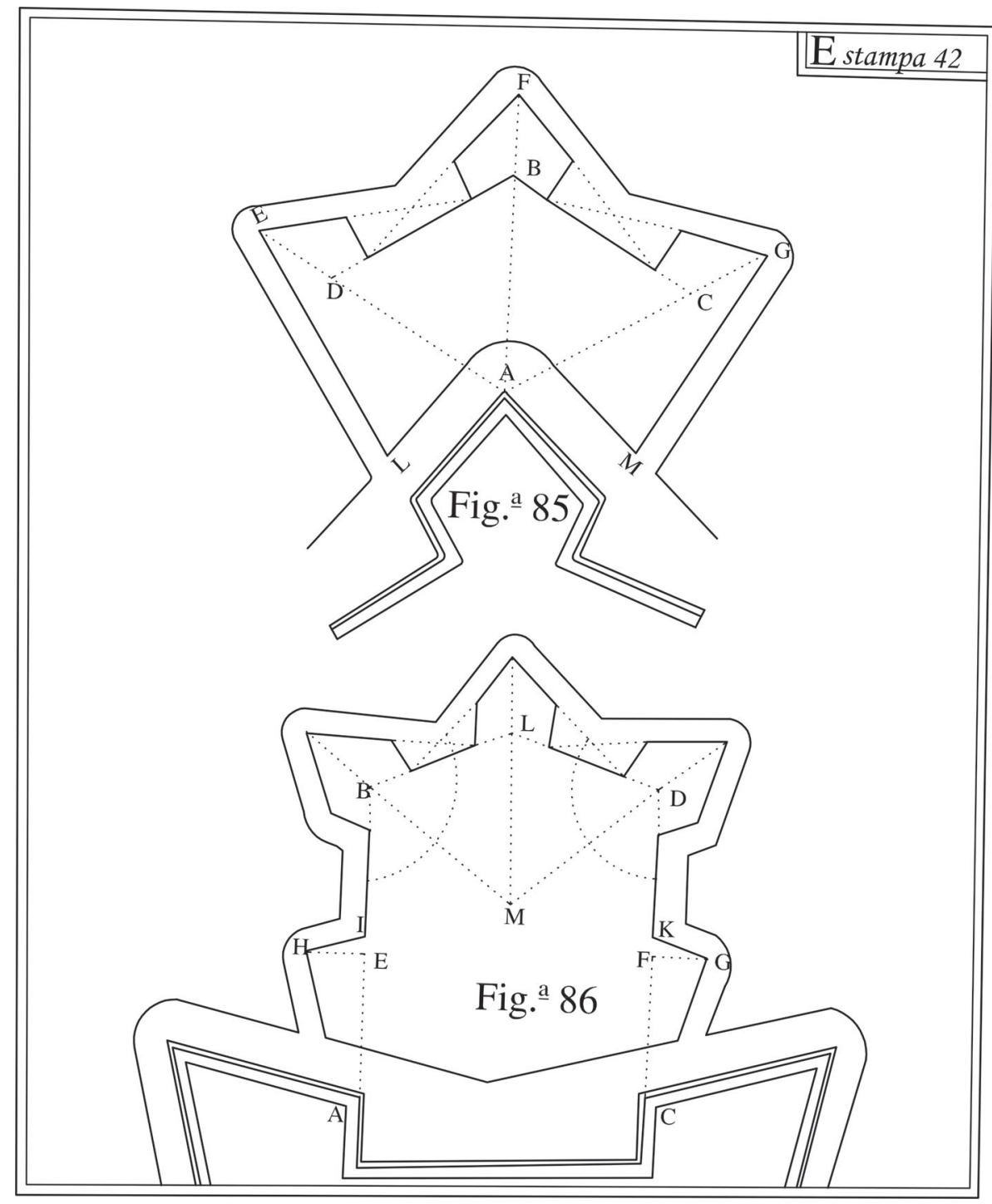




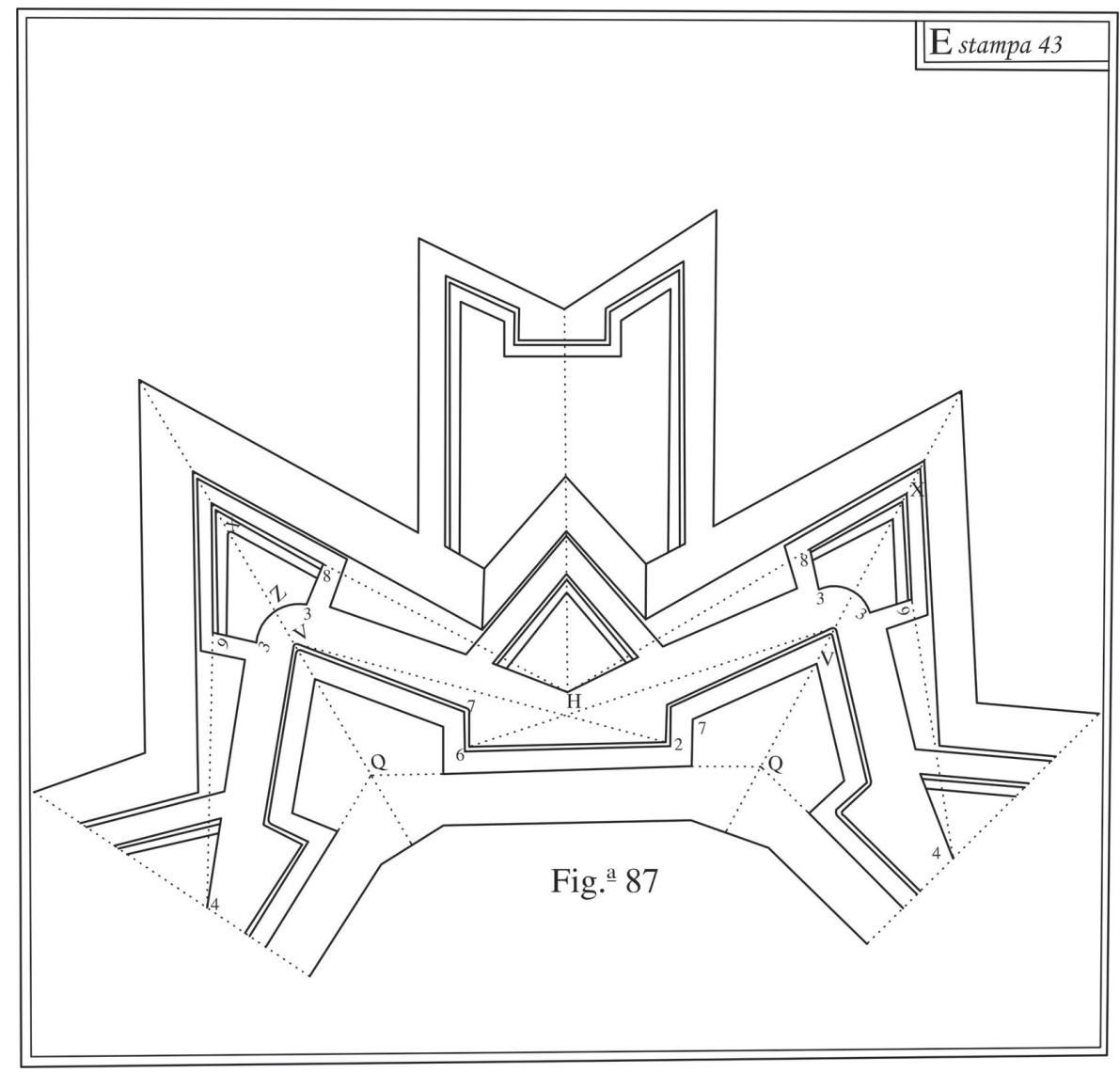




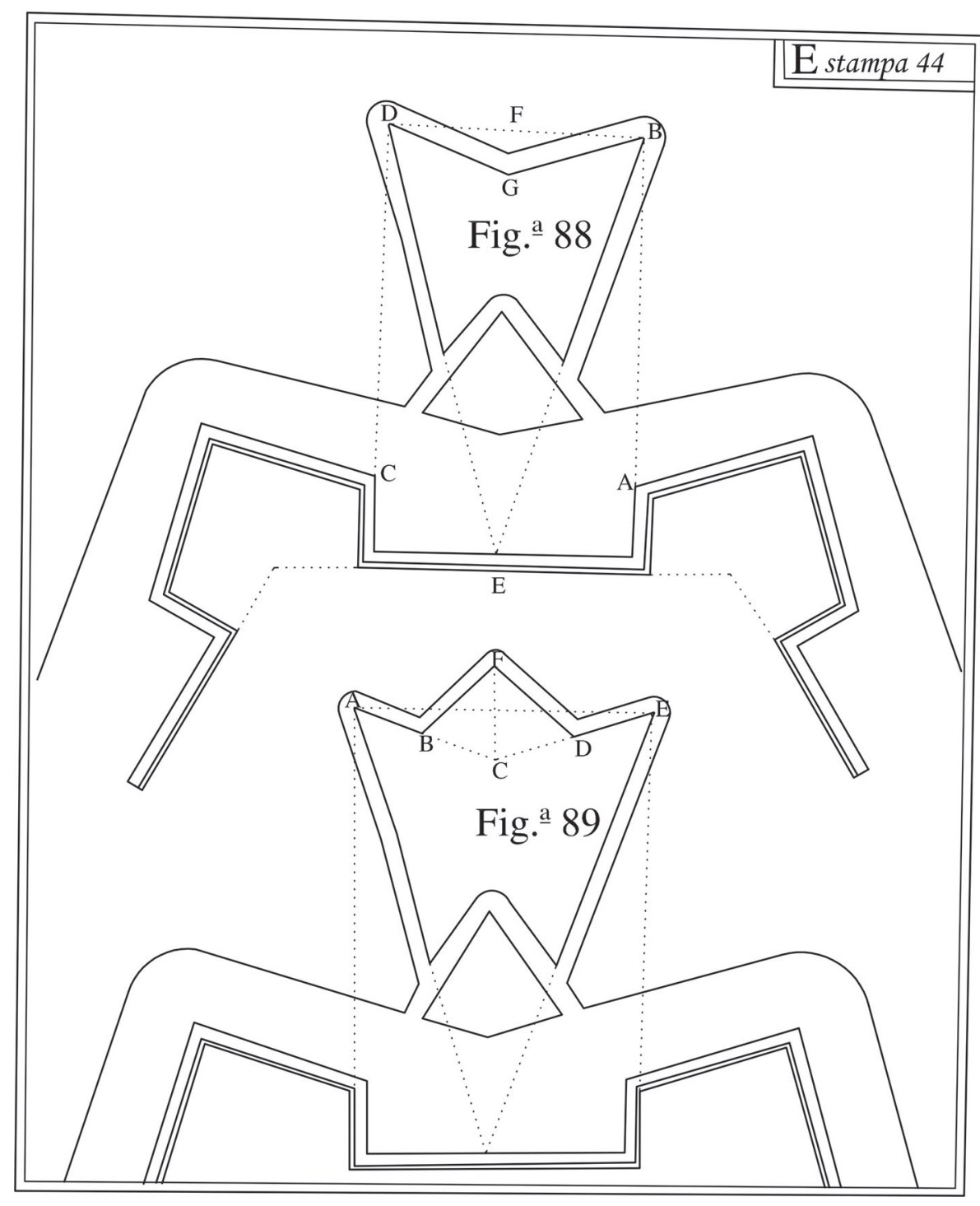




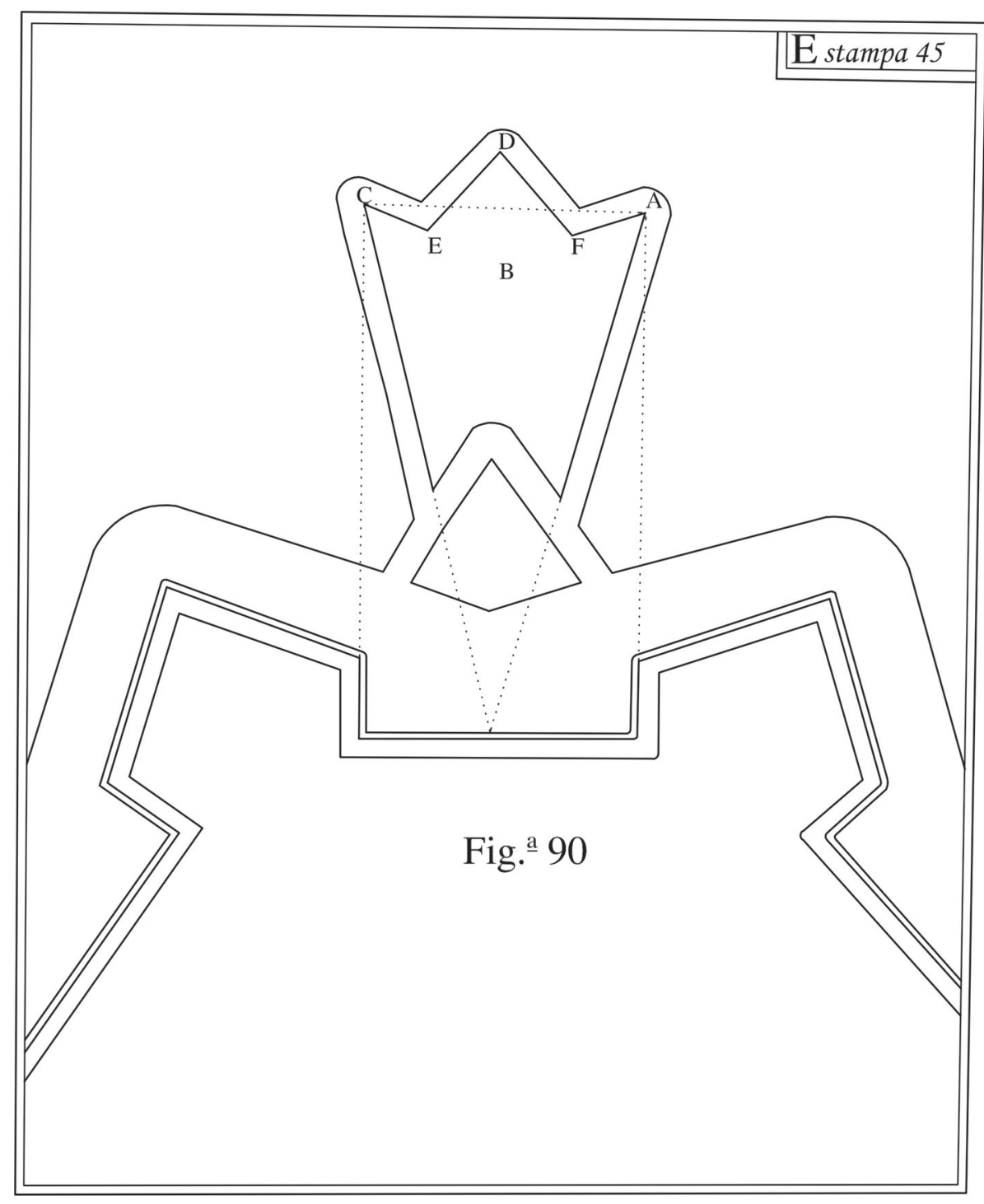




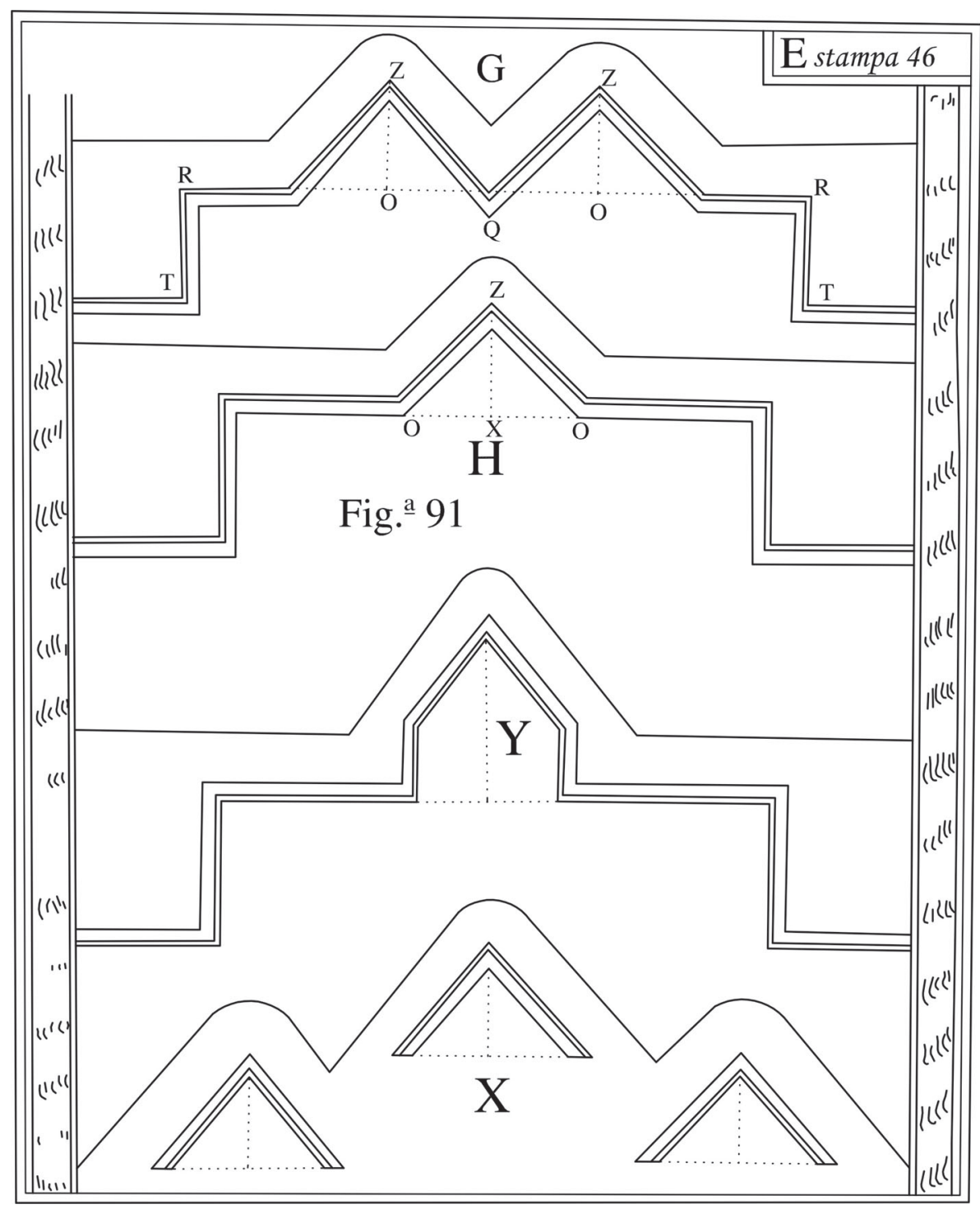




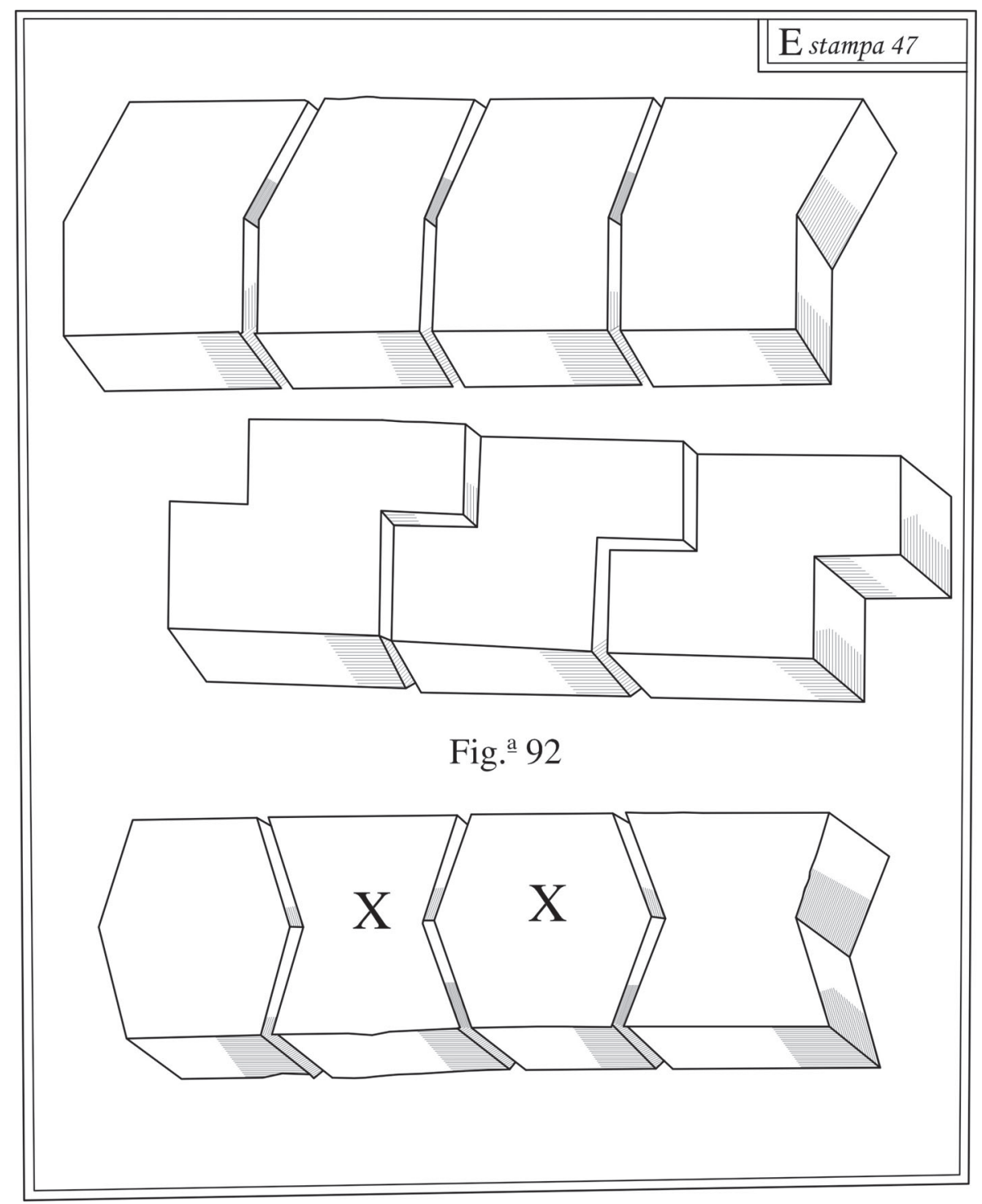




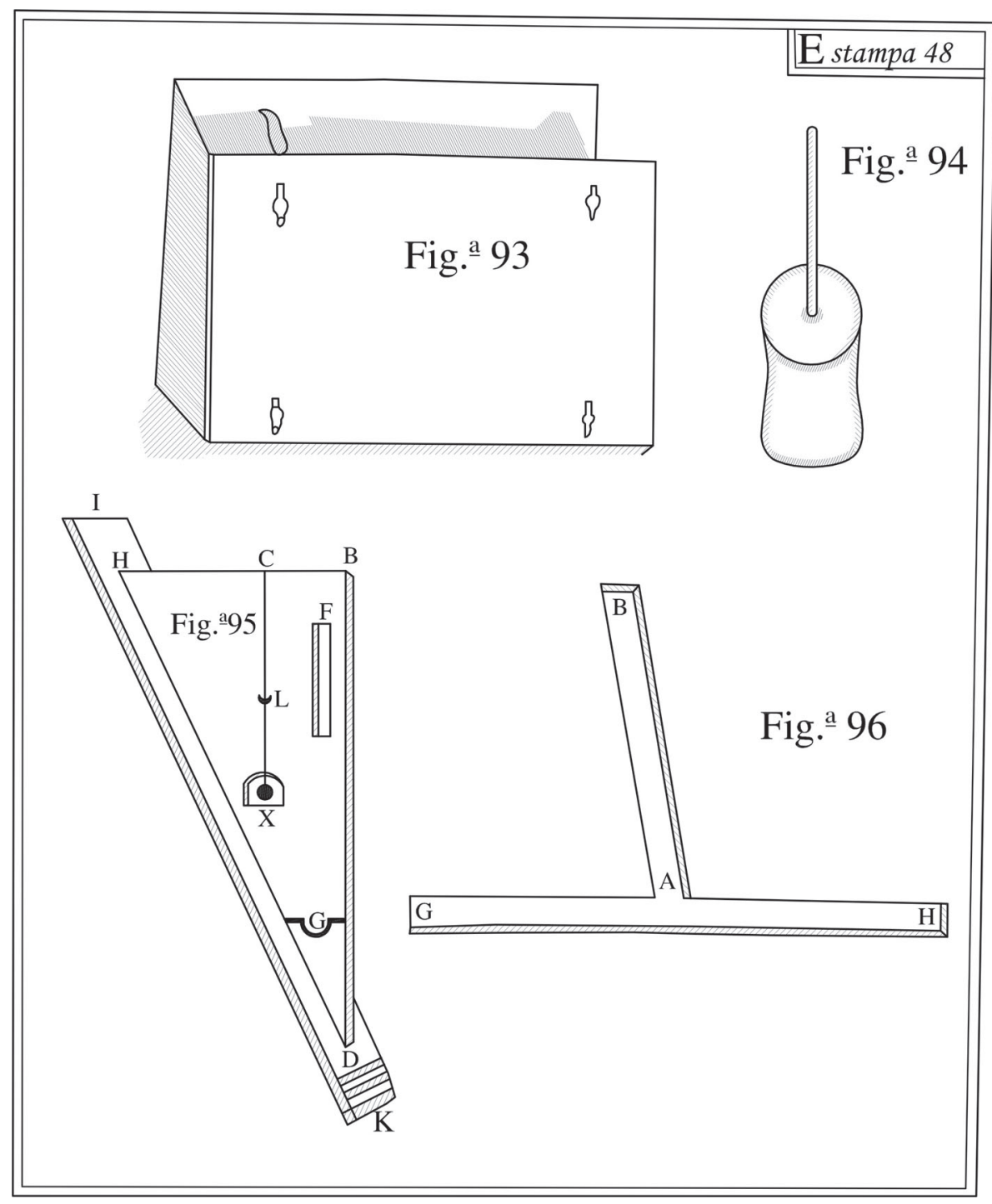




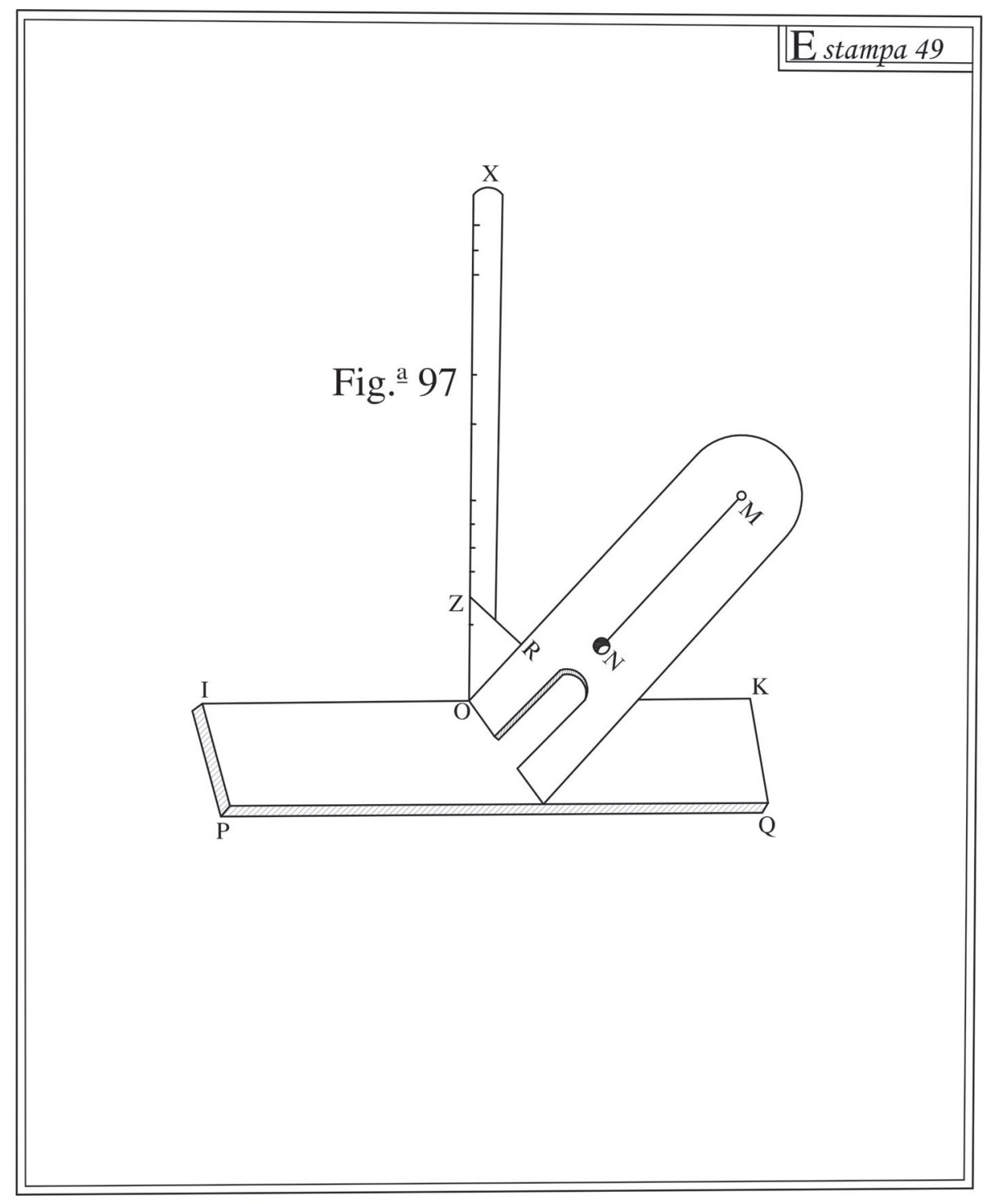




\section{[BIBLIOGRAFIA DE REFERÊNCIA]}

ALBERTI, Leon Baptista. L'Architettura (De Re Adificatoria). Trad. Giovanni Orlandi. Milano: Il Polifilo, 1966. p. 184.

BERRIMAN, A. E. Historical Metrology. London:J.M. Dent \& Sons, 1952. 224p. il.

CATANEO, Pietro. I Quattro primi libri di Architettura. Vinegia [sic]:

Figliuoli do Aldo, 1554.

FORTE, Manoel de Azevedo. O engenheiro português. Lisboa: Manoel Fernandes da Costa, 2v., 1729.

MAGGI, Girolamo e CASTRIOTTO, Iacomo. Della fortificatione delle cita. Venetia: Camillo Borgominiero, 1583. Edição facsimilada por Juvence Viella, com introdução de Giorgio E. Ferrari.

MARINI, Luigi. Biblioteca Istorico-critica di fortificazione permanente. Roma, Mariano di Romanis e Figli, 1810. 461p.

NUNES, Antônio Lopes Pires. Dicionário temático de arquitectura militar e arte de fortificar. Lisboa: Estado maior do Exército, 1991.250p. il.

OLIVEIRA, Mário M. Morfologia dos fortes do mar da defesa de Salvador. In: IV Congresso de História da Bahia. Salvador: Anais...27 setembro a 1 de outubro de 1999. Salvador: IGHBA/FGM, 2001. v.1,p.481-497.

OLIVEIRA, Mário M., PRESA, Erundino Pousada. Reinforcing foundations with wood piles: Origin and historic development. In: First Congress on Construction History. Madri: Anais... Janeiro 20-24, 2003. p. 1537-1545.

OLIVEIRA, Mário M. As fortificações portuguesas de Salvador quando Cabeça do Brasil. Salvador: Fundação Gregório de Matos, 2004. 260p. il.

PIMENTEL, L. Serrão. Methodo lusitanico de desenhar as fortificacoens das praças regulares \& irregulares, fortes de campanha e outras obras pertencentes a architectura militar. Lisboa: Antonio Craesbeeck, 1680. Edição facsimilada de 1993.676p. il.

POLLAK, Martha D. Military architecture, cartography and the representation of the early modern European city. Chicago: The Newberry Library, 1991. 119p. il. 
VAUBAN, Sebastien le Preste de. (Le triomphe de la Méthode) Traitéde l'attaque dès places de Monsier de Vauban Ingenieur du Roi. Organização e apresentação de Nicolas Faucherre et Philippe Prost. Paris: Gallimard, 1992.

VITERBO, Francisco de S. Dicionário histórico e documental dos arquitectos, engenheiros e construtores portugueses. Lisboa: Imprensa Nacional, $1922.3 \mathrm{v}$. Ed facsimilada de 1988.

VIRUVIO, Marco L. Los Diez libros de arquitectura. Tradução de Agustín Blanquez. Barcelona: Ibéria, 1991. 
Este livro foi publicado no formato $140 \times 170 \mathrm{~mm}$

Miolo em papel $75 \mathrm{~g} / \mathrm{m}^{2}$

Impressão de capa e acabamento:

Bureau Gráfica e Editora

Tiragem: 600 exemplares 